\title{
The Nanyang Chinese National Salvation Movement, 1937-1941
}

Yoji Akashi

International Studies, East Asian Series

Research Publication, Number Five

Center for East Asian Studies

The University OF Kansas 
The Nanyang Chinese National Salvation Movement, 1937-1941 


\title{
The Nanyang Chinese National Salvation Movement, 1937-1941
}

\author{
Yoji Akashi
}

International Studies, East Asian Series

Research Publication, Number Five

Center for East Asian Studies

The University OF Kansas 
Copyright (C) 1970

Center for East Asian Studies

The University of Kansas

Library of Congress catalog card number: $73-629780$

All rights reserved

Manufactured in the United States of America

Sole distributors in the USA \& Canada

Paragon Book Gallery, Ltd.

14 East 38th Street

New York, N.Y. 10016 


\section{Contents}

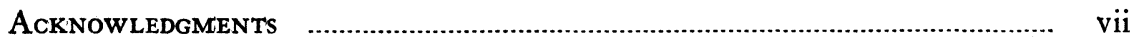

INTRODUCTION

I. The Nanyang Chinese National Salvation Movement, First Phase (1937-1938) ............................................................................... 15

II. The Nanyang Chinese and the Anti-Japanese National Salvation Movement, Second Phase (October, 1938-December, 1941)

III. Achievements of the Nanyang Chinese National Salvation Movement and its Economic EfFectiveness

IV. Summary and Conclusions …............................................................ 159

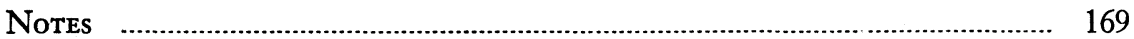

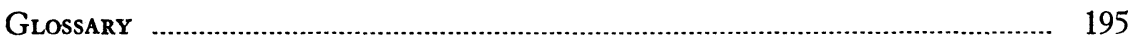

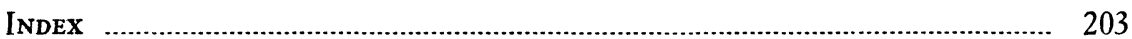

\section{Figure and Tables}

FigURE

PAGE

1. A Chart Showing Relationships Between the KMT GovernmentParty and the Nanyang Chinese

TABLE

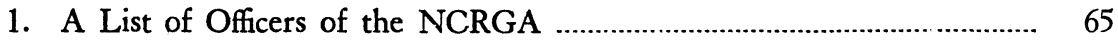

2. A List of KMT Officials Who Visited Southeast Asia, 1937-1941 .......... 120

3. A Breakdown of Nanyang Chinese Contributions from July, 1937, to October, 1938

4. A Breakdown of Nanyang Chinese Contributions from November, 1938, to December, 1940

5. KMT Government's Receipt of Contributions from the Nanyang Chinese Covering the Period from July, 1937, to October, 1940

6. Nanyang Chinese Contributions Per Capita, November, 1938, to October, 1939

7. Nanyang Chinese Remittances and China's Balance of Payments, 1936-1941

8. A List of Principal Enterprises in Which Nanyang Chinese Had Invested or Planned to Invest as of 1941 
9. Japanese Export Trade to Southeast Asian Countries, 1936-1941, Showing Relatives and Link Relatives

10. Value in Japanese Yen (Millions) of Goods Moving from Japan to Malaya, 1937-1939

11. A Comparative Chart Showing a Shift in Malaya's Imports in Relation to Japan, Britain, and China

12. Value in Japanese Yen (Millions) of Goods Moving from Japan to the Dutch East Indies, 1937-1939

13. A Comparative Chart Showing a Shift in the Dutch East Indies' Imports in Relation to Japan, the Netherlands, and China

14. Value in Japanese Yen (Millions) of Goods Moving from Japan to the Philippines, 1937-1939

15. A Comparative Chart Showing a Shift in Philippines' Imports in Relation to Japan, the United States, and China

16. Value of Japanese Yen (Millions) of Goods Moving from Japan to Thailand, 1937-1939

17. A Comparative Chart Showing a Shift in Thailand's Imports in Relation to Japan, Britain, and China

18. Value in Japanese Yen (Thousands) of Goods Moving from Japan to French Indochina, 1937-1939

19. A Comparative Chart Showing a Shift in French Indochina's Imports in Relation to Japan, France, China, and Hong Kong 


\section{Acknowledgments}

I must first acknowledge my great debt to Professor Edgar Wickberg of the University of British Columbia. He read the entire manuscript twice. He has been a constant perceptive critic, and for his pains he has had only the dubious satisfaction of reading the manuscript in nearly all of its revisions.

At various stages the manuscript was read by Professor Wei-Kou Lee and Father Joseph S. Sebes, S.J., both at Georgetown University, Washington, D.C., Professor Kenneth P. Landon of the American University, Washington, D.C., Professor Wang Gungwu of the Australian National University, Canberra, Australia, and Professor Howard Mattsson-Boze, my colleague at Geneva College. All encouraged me in the publication of the manuscript and made valuable suggestions about both form and content.

I wish to express my thanks for the use of materials and facilities to the staff of the Japanese Section, particularly Messrs. Andrew Y. Kuroda, Key Kobayashi, and Mrs. Lillian K. Takeshita, the Library of Congress, Washington, D.C.; to the staff of Tōyō Bunko (Oriental Library); to Kindai Chūgoku Kenkyūjo (Institute of Modern China), particularly Professor Sasaki Masaya; to Mr. Kishi Kōichi of Ajia Keizai Kenkyüjo (Institute of Asian Economic Affairs); to the staff of the Foreign Office Archives; and to the staff of Boeichō Kenshūjo Senshi-shitsu (Historical Section, Defense Agency), all in Tokyo.

I would like to record my deep appreciation to Mrs. Virginia Platt for editorial work. She worked long and hard to bring order where chaos reigned. My gratitude goes to Professor Grant K. Goodman of the Center for East Asian Studies, the University of Kansas. He gave me useful editorial advice that saved me from embarrassment. My thanks are also due to Mrs. June Futato for typing the entire manuscript. Finally, my wife has shared many a night into the wee hours with me in giving me moral support. I am alone responsible for those errors of fact and evaluation which surely remain.

Fall, 1969

Beaver Falls, Pa. 


\section{Introduction}

The relations of Chinese governments with the Nanyang Huach'iao (South Seas Chinese) go back to the Ming dynasty (1368-1636), when the imperial court largely abandoned the Nanyang Chinese and forbade them, on punishment of death, to leave their ancestral land. Furthermore, the Imperial court absolved itself of responsibility for the protection of its emigrants on the grounds that these people were deserters of ancestral tombs and therefore unworthy of China's protection. ${ }^{1}$ The policy of the Manchu government (1636-1911) was even harsher than that of the Ming government, particularly during the early years, partly because a large number of Chinese who had migrated to the region beyond China's southern border were selfexiled remnants loyal to the deposed Ming government. Even in the eighteenth century the Manchu government was unwilling to act to protect the lives of unfilial Chinese, leaving them to the mercy of local rulers. ${ }^{2}$ It is a well-known story that in 1741, Emperor Ch'ien Lung dismissed a Dutch envoy sent to apologize for the infamous massacre of Chinese in Batavia, saying that it caused "no concern of the Imperial Court" because these Chinese had disgraced their ancestors by deserting their family tombs in the quest for money. ${ }^{3}$

In fact, it was only after the 1860 's that China became interested in the overseas Chinese, and it was not until 1877 that the first Chinese consulate was set up at Singapore-despite the fact that Chinese had lived there for three hundred years. It took eighteen years for the Manchu government to establish the first consulate in the Philippines. It was set up in 1898; the final decision was based primarily upon economic interest. ${ }^{4}$ Moreover, Chinese who returned from abroad were subjected to extortion and interrogation by local officials because the edicts of 1717 and $1729^{5}$ had neither been rescinded nor enforced, and the Manchu dynasty law code (Ta-Ch'ing Lü-li) also stipulated harsh penalties for emigration overseas. ${ }^{6}$

Such a policy naturally engendered ill feelings among the Huach'iao toward the Manchu government. Their anti-Manchu sentiments, however, were not immediately translated into support of Sun Yat-sen's revolutionary movement-at least not financial support. Although some overseas Chinese from Malaya took part in the famous Huang 
Hua Kang Revolt in April, 1911, much-needed contributions to the revolutionary funds were not forthcoming from Nanyang Chinese until Sun's revolution appeared almost certain to succeed. Only then did they pour money into his coffers. ${ }^{7}$ The successful revolution enhanced the prestige of Sun and his republican party. For the Nanyang Hua-ch'iao, however, he was only a symbolic nationalist, not the leader of their communities; Sun could not "extend the help and protection demanded by the overseas Chinese." His prestige and the luster of the republican government in Southeast Asia began to wear off, and by 1915 they had little magic power of appeal to the Nanyang Chinese. ${ }^{8}$ China under Yuan Shih-kai, who usurped the power from the republicans, was weak and ineffectual when Japan presented the Twenty-One Demands.

The Twenty-One Demands, which would have made China a Japanese colony had she accepted, aroused Chinese national indignation. In concert with the boycott movement in China, Nanyang Chinese boycotted Japanese goods; it was a movement conducted largely by Chinese Chambers of Commerce and their affiliates. ${ }^{9}$ Four years later, they staged another anti-Japanese campaign against the Japanese position on the Shantung question at the Paris Peace Conference. ${ }^{10}$ Reflecting the May Fourth Movement spirit, students and intellectuals took over the leadership in the campaign. Unlike the 1915 boycott, it was a mass drive supported by the press and schools. ${ }^{11}$ As Chinese nationalism spread, a reorganized Kuomintang (KMT) government emerged, once again under Sun Yat-sen's leadership. As an old revolutionary active abroad, Sun naturally took interest in the rising political consciousness of the overseas Chinese. As early as 1920, KMT school teachers came to Malaya to staff Chinese schools and inculcate in Chinese children Sun Yat-sen's Three Principles (Nationalism, Democracy, and Livelihood), patriotism, and Chinese history. ${ }^{12}$ Then in 1924, a year after the 1923 anti-Japanese boycott movement that swept China and Nanyang Chinese communities when Japan insisted on holding her territorial claim over the Liaotung peninsula, the KMT government created the Office of Overseas Chinese Affairs - the first concrete step the KMT government seriously considered for protecting the welfare of their overseas compatriots and for mobilizing a mass support for KMT nationalism. The Office, however, was short- 
lived; already weakened by neglect, it became defunct after Sun Yatsen's death in $1925 .^{13}$ In 1926, at the Second KMT Congress, overseas Chinese delegates passed resolutions urging the government to reactivate the Office. The government granted their request. ${ }^{14}$

After the death of Sun, Chiang Kai-shek inherited the mantle of the deceased leader and unified China in 1927, under KMT control. Being a mass-based revolutionary party, the KMT naturally sought to bring all nationalist movements at home and abroad under its discipline in order to promote Chinese nationalism. The need to solidify them became acute upon the emergence of new forces threatening the viability of China: the Japanese and the Communists. To Chiang, the Communists were less dangerous than the Japanese, who appeared to stand in the way of China's becoming a strong state. The first of a series of military clashes between Japan and China occurred in 1928 at Tsinan. In the 1928 anti-Japanese movement, the KMT government for the first time took an active part in such a campaign, transforming the drive from a resistance movement against aggressors to a nationalist movement for the survival of the Chinese race. In other words, the anti-Japanese campaign now became part of the Chinese nationalist movement. At the same time, the cultivation of anti-Japanese feelings and national-salvation thought through party education became important. Consequently, the scope of the anti-Japanese movement was broadened to include not only boycotts but also contributions, labor service, investment, and other methods to be used in the national salvation movement.

Though the KMT took over the leadership of the national salvation movement after 1928, the systematization had started as early as 1926 , and it was strengthened during and after the Manchurian incident. For its overseas operation, three organizations were primarily responsible for overseas Chinese education, party indoctrination and discipline, guidance, and propaganda: the Overseas Party Affairs Department, the Overseas Chinese Affairs Commission, and the Foreign Ministry with its diplomatic mission abroad (see Figure 1).

The reorganized KMT began in 1924 to establish its network in Nanyang Hua-ch'iao communities. By the time the Second Party Congress met in 1926, the KMT had set up headquarters in Burma, French Indochina, Nanyang (Malaya-Dutch Indies), the Philippines, 
Figure 1

A CHART SHOWING RELATIONSHIPS BETWEEN

THE KMT GOVERNMENT-PARTY AND THE NANYANG CHINESE

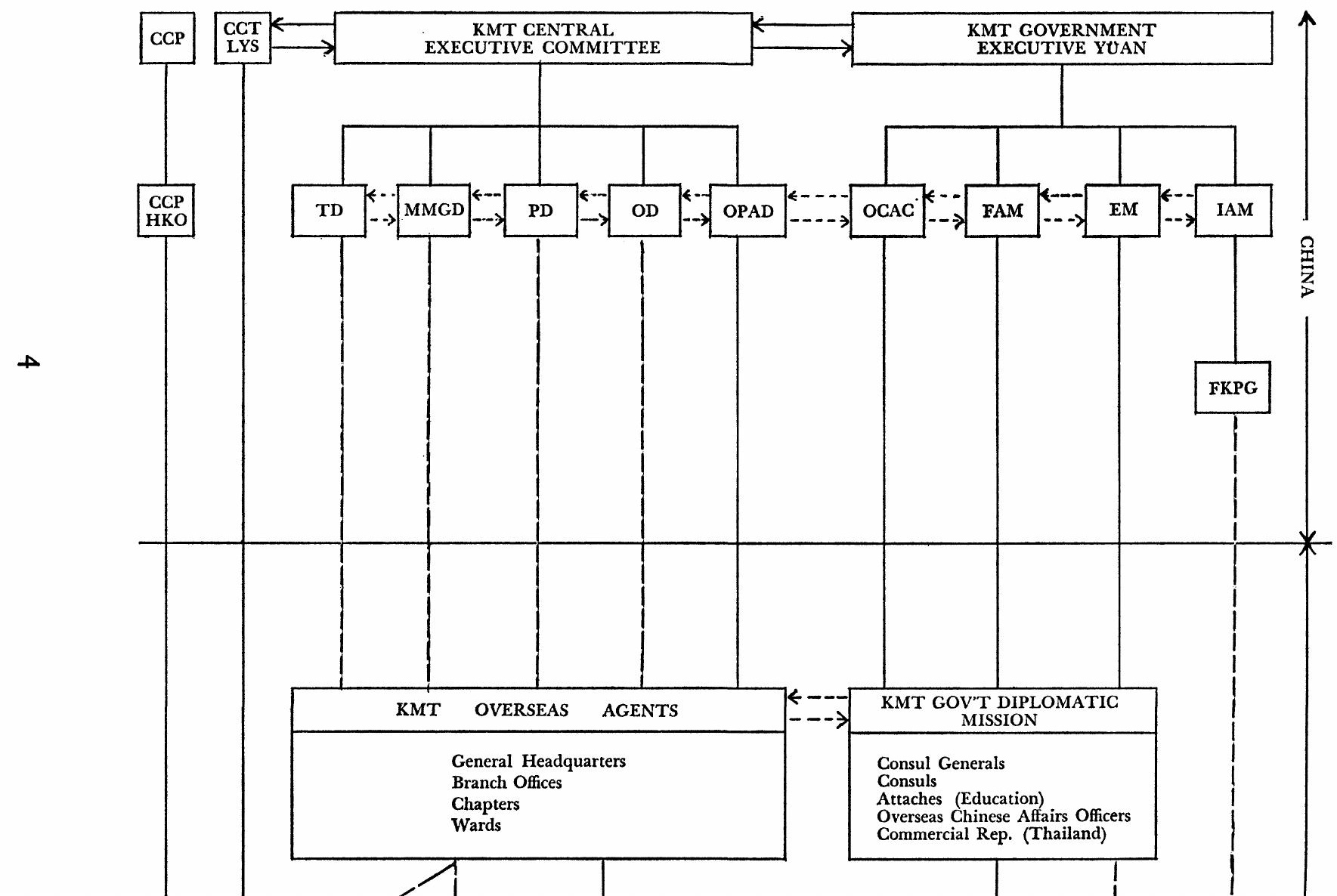




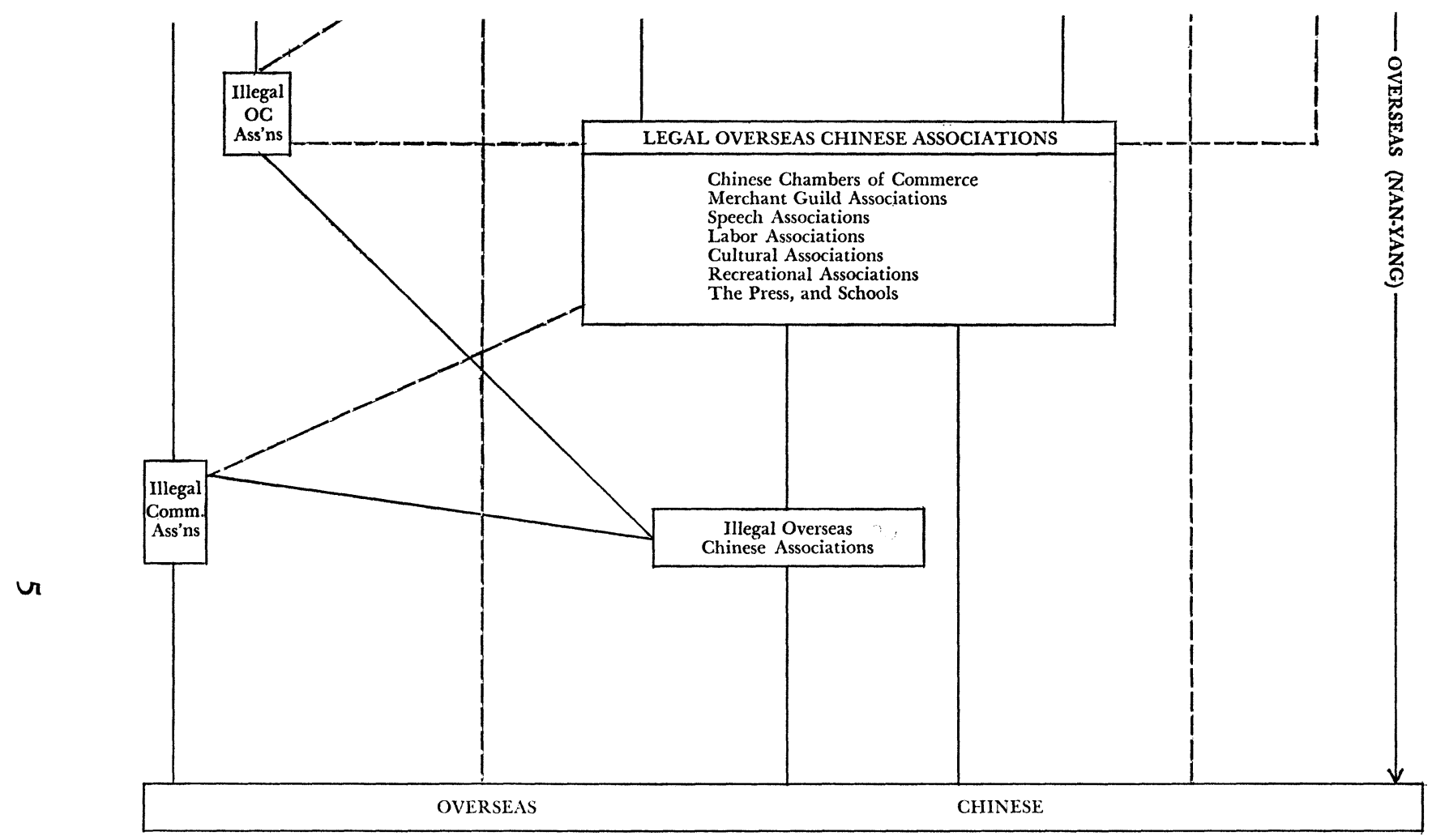

$\begin{array}{ll}\text { CCP } & \text { Chinese Communist Party } \\ \text { CCP, HKO } & \begin{array}{l}\text { Chinese Communist Party, Hong Kong Office } \\ \text { C. C. T'uan }\end{array} \\ \text { LYS } & \text { Lan-yi she } \\ \text { TD } & \text { Training Department } \\ \text { MMGD } & \text { Mass Movement Guidance Department } \\ \text { PD } & \text { Propaganda Department } \\ \text { OD } & \text { Organization Department } \\ \text { OPAD } & \text { Overseas Party Affairs Department }\end{array}$

OCAC Overseas Chinese Affairs Commission

FAM Foreign Affairs Ministry

EM Education Ministry

IAM Internal Affairs Ministry

FKPG Fukien, Kwangtung Provincial Governments

OC Overseas Chinese

OPAD Overseas Party Affairs Department

Direct line of communication

__ Indirect line of communication 
and Thailand, controlling 300 branch offices and chapters with a total of 31,000 members. ${ }^{15}$ Eight years later, the number of KMT organizations and their membership had doubled, most of the increase occurring in the British territories, the Dutch Indies, and Thailand. ${ }^{\mathbf{1 6}}$ Activities of overseas party organizations were defined in The Organization Act for the Overseas General Headquarters Executive Committee, approved in April, 1934, by the KMT Central Executive Committee, the supreme party agency. The overseas party branches were to (1) train and guide party members to plan propaganda and educational policies in conformity with party directives and to disseminate propaganda through the party newspapers; (2) support Hua-ch'iao schools and social activities; (3) help to organize functional associations; and (4) plan policy for lower echelon party members. ${ }^{17}$ These activities were conducted by the Overseas Party Affairs Department, established in July, 1932, which took over activities of the Overseas Chinese Affairs Commission.

The Overseas Party Affairs Department was the most important organization for KMT overseas operation. Working under the direct control of the Central Executive Committee, which coordinated activities with the KMT government Executive Yuan, the Department was responsible for organizing and expanding party affairs, disseminating news through party newspapers and publications, disciplining and indoctrinating party members and training them for overt and covert activities, drafting plans for propaganda in cooperation with the Organization and Propaganda Departments, supervising the consulate's coordination with the party, and protecting the Hua-ch'iao. The Department was the only party agency with a direct line to every segment of Hua-ch'iao communities, serving as a watchdog for the Central Executive Committee. Through its overseas agents (General Headquarters, branch offices, chapters, and wards), the Department supervised education and party activities within Hua-ch'iao associations. It also investigated the distribution of Chinese, their living conditions, patriotic movements, associations, and attitudes toward the party as well as the policies of Southeast Asian governments toward the Chinese. ${ }^{18}$

Moreover, in cooperation with the KMT Mass Movement Guidance Department, which was created in the midst of the Sino-Japanese hos- 
tilities in the spring of 1932, the Overseas Party Affairs Department was responsible for organizing a mass nationalist movement. The Revised Guiding Principles for Mass Movement, issued by the Department in February, 1933, spelled out to overseas agents the details of the propaganda policy for achieving their objective. ${ }^{19}$ The eight-fold objective was stated as follows:

(1) To mobilize the masses to engage in a resistance movement against [Japanese] aggression;

(2) To enlighten the masses in self-defense consciousness in order to engage them in a systematically planned resistance movement;

(3) To encourage the masses to engage in combat and non-combat duties;

(4) To organize the masses in a militia to help maintain local security and assist the military;

(5) To guide the masses to buy national goods;

(6) To organize civil associations to help the government's relief work and to prevent a Communist agitation among refugees;

(7) To open the line of communication among the party, the government, and the masses for a better understanding and for the unity of the three bodies; and

(8) To encourage the masses to organize special units such as comfort missions, fund-raising groups, and student volunteer corps.

In June, the Department announced Plans for Mass Movement To Be Guided by Party Chapters and Wards, which supplemented Propaganda Operation Plans To Be Implemented by the Chinese General Headquarters and Branch Office, passed in February, 1931. ${ }^{20}$ The Plans stressed the importance of person-to-person communicationhome visitation, individual dialogue, and circuit lectures-in the propagation of party doctrine and proper understanding of KMT national policy. Both Plans and Propaganda Operation Plans emphasized the usefulness of the mass assembly for generating a sense of participation. The press, library and reading clubs, school events, drama troupes, theaters, concerts, garden parties, sports events, merchant guilds, and labor, speech, and religious associations were specifically mentioned as effective vehicles for creating national unity and raising funds.

In these two ordinances we see elements that were to crystallize into components of the 1937-1941 Nanyang Chinese National Salvation Movement. That the KMT applied these decrees to the Nanyang Chinese as if they were Chinese citizens, regardless of their nationalities, is important.

Together with the Propaganda Department and the Overseas 
Chinese Affairs Commission, the Overseas Party Affairs Department managed and controlled a number of party newspapers published in Southeast Asian countries. ${ }^{21}$ They were the Hsin Kuo Min Jit Poh (Singapore); the Kwang Wah Jip Poh (Penang); the Ma Hua Jih Pao (Kuala Lumpur); the Kak Min Jit Poh (Rangoon); the Kong Li Po (Manila); the Min Kuo Jih Pao, the Bangkok Jit Poh, the Hua-ch'iao Jih Pao, the Hua Hsien Jih Pao, the Lak Muang, the Issara, and the Khao Siam (all in Bangkok); the Thien Sung Jip Po (Batavia); and the Hua-ch'iao Jih Pao and the Annan Jit Po (Cholon). Naturally, the editorial policy of these newspapers was anti-Japanese.

Party discipline extended also to non-party Chinese dailies. For example, the Propaganda Operation Plans To Be Implemented by the Overseas Chinese General Headquarters and Branch Offices passed in February, 1931, ${ }^{22}$ empowered the overseas KMT agents to "reorganize" an editorial board and to "replace" the publisher or the editor of an non-party newspaper if its editorial was "reactionary." They also were given authority to "discipline" a non-cooperative newspaper publisher if "persuasion" failed, to recommend that such a newspaper be boycotted, or to request the Propaganda Department to "punish" the publisher. The Chinese wire service came under the same disciplinary control. Furthermore, Chinese publishing newspapers and magazines were required to register for examination with either local Chinese authorities (Embassy or Consulate) or the Overseas Chinese Affairs Commission, according to the Registration Act for Overseas Chinese Newspapers and Magazines, promulgated jointly by the Overseas Chinese Affairs Commission and the Internal Affairs Ministry in June, 1934. Publishers were not only prohibited from printing articles detrimental to the KMT government's national interests but also were required to file copies of each edition with the Internal Affairs Ministry, the Overseas Affairs Commission, and the Overseas Party Affairs Department. ${ }^{23}$

The most influential dailies in the South Seas countries were not party-controlled papers, however. They were the Nanyang Siang Poh and the Sin Chew Jit Poh (Singapore); the Sin Po (Batavia); and the Fookien Times and the Chinese Commercial News (Manila). These widely circulated newspapers were owned, managed, or edited by China-oriented, influential Chinese businessmen and intellectuals in 
their communities, who supported the KMT government and its party ideology. ${ }^{24}$ Minor Chinese-operated presses reprinted articles and feature stories from the Big Five and depended upon the KMT government's Central News Agency for news service.

Jointly with executive branches, the Overseas Party Affairs Department supervised and guided all Nanyang Chinese associations. The Nanyang Chinese had a great penchant for organization, from which the Chinese government and the KMT profited enormously. The KMT, in most Southeast Asian countries, used many of these associations as its front. According to the Organization Laws Concerning People's Associations, passed by the Central Executive Committee in $1933,{ }^{25}$ Nanyang Chinese associations were without exception required to submit to the guidance of the KMT and its government agents, adhere faithfully to the Three Principles, and obey government orders (Articles II and III). Another Central Executive Committee decree required executive members of all associations to swear before party officials that they would "endeavor to execute the principles of the San-Min-Chu-I to the best of [their] ability. ..." Should they violate the oath, they were to "submit to a severe discipline." 26

The most powerful Nanyang Hua-ch'iao organization was and is the Chamber of Commerce. Chambers of Commerce had been established in principal cities throughout Southeast Asia. Leaders of the Chambers of Commerce were China-oriented. In boycott drives against Japan before 1937, the organization had played a leading role. It was only logical that the KMT and its government take upon themselves the task of amending the old laws regulating activities of the Chamber of Commerce. Under a new set of laws issued in 1929, a KMT approval was the prerequisite for founding a new Chamber of Commerce. The raison d'etre of the Chamber of Commerce was primarily economic, but its activities in Southeast Asia extended far into the arena of politics. Its politico-economic influence was pervasive in Chinese communities. Traditionally, the Nanyang Chinese Chamber of Commerce had served as a semi-official agency of the Chinese government and, during the KMT period, it had served as a medium for the cultivation of national consciousness. On the other hand, because the Chamber of Commerce had existed for the protection of Chinese community interests long before the KMT government was founded, it remained 
to a considerable degree independent of the KMT's attempt to control it.

There is another important area-education-in which the KMT executive branch (particularly the Overseas Chinese Affairs Commission, the Foreign Affairs Ministry through its overseas diplomatic mission, and the Education Ministry) played a predominant role in shaping and moulding overseas Chinese patriotism.

The interest of the KMT government in the education of Nanyang Chinese children was evidenced by the 1929 national educational conferences, held under the auspices of the Commission and Chinan University, together with other party and government agents. At their first meeting, it was resolved that the San-Min-Chu-I was to be the basic doctrine in the teaching of Chinese children abroad, and at the second conference, teachers from abroad expressed their wish to teach the Chinese language and Chinese history slanted towards the KMT ideology. They demanded that KMT members train them without interference from local authorities. ${ }^{27}$ Later in 1929, the third conference on education was held, again under the auspicies of the Commission and the KMT Training Department. From these three conferences emerged a document, the Principles of Hua-ch'iao Education, which was promulgated by the Executive Yüan in $1932 .{ }^{28}$ Thus, by 1933, the KMT educational policy had been founded on KMT ideology. Both Japanese and Chinese sources agree that the KMT government succeeded to a high degree in cementing the national unity of the Huach'iao and strengthening their national consciousness through educational media. ${ }^{29}$

The Overseas Chinese Affairs Commission, which had played a significant part in the overseas educational program, was in 1931 placed under the jurisdiction of the Executive Yüan-a step taken apparently to bring the Commission into a closer relationship with the supreme executive body. Under a new Organization Law, promulgated in December, 1931, and amended in August, 1932, the Commission was made responsible, together with the Foreign Affairs Ministry, for supervising Chinese consular operation, which included education. Indeed, the Commission was now the supreme organ under the Executive Yüan for overseeing all overseas Chinese activities and educa- 
tion, and in the latter area the Commission coordinated with the Education Ministry. ${ }^{30}$

Under the direction of the Overseas Chinese Affairs Commission, the consulate, besides attending to its normal duties through the channel of the Foreign Affairs Ministry, assumed responsibility for the supervision of education within the ideological and doctrinal framework of the San-Min-Chu-I. Consular duties in relation to the education of Chinese youths and children abroad were stipulated in legislative acts passed by the KMT government, such as the Consular Act for the Guidance of Hua-ch'iao Schools and Auxiliary Schools, the Consular Regulations for the Legislation and Administration of Huach'iao Education, and the Consular Act for the Guidance of Hua-ch'iao Shu Pao She and Other Educational Facilities Concerning Lectures to be Given on Sundays and Memorial Days. ${ }^{31}$ Together they spelled out policies for the improvement of the educational system and the quality and promotion of national and party loyalty. According to these acts, the consul was to (1) examine the Hua-ch'iao educational system and report findings once a year to the Overseas Chinese Affairs Commission and the Education Ministry; (2) see that all educational ordinances and laws decreed by the KMT government were observed and that education in the party doctrine was enforced; and (3) guide local libraries, newspapers, and cultural organizations, urging them to hold as many lecture meetings as possible on Sundays and memorial days. Such lectures were to stress the tenets of the party doctrine, summarize current affairs, and exalt patriotism.

The Chinese government had extra-legal societies through which it reached overseas Chinese communities. They included the C. C. T'uan and the Lan-yi she, of which not much was known except that they maintained a lateral but very close personal relationship with some of the most influential figures in the party and the government. The Lan-yi she, for instance, was a super-secret intelligence and espionage organization operating under the direct command of $\mathrm{Tai} \mathrm{Li}$, Chiang Kai-shek's trusted confidant and one of the most feared and powerful men in the KMT government. The C. C. T'uan was known to have been created by two brothers, Ch'en Li-fu and Ch'en Kuo-fu, close friends of Chiang Kai-shek and leaders of one of the controlling KMT factions with a strong conservative and right-wing outlook..$^{32}$ These 
secret organizations directly controlled their respective overseas members and had dealings with illegal overseas societies. Through these overseas agents, the Lan-yi she and the C. C. T'uan reached overseas Chinese.

Another illegal Chinese political party interested in the Nanyang Chinese was the Communist Party. The Communist Party had been active in Nanyang Hua-ch'iao communities since the 1920's. From its headquarters in Singapore, for instance, the Communist-dominated General Labor Union, in close contact with the Chinese Communist Party, coordinated the strategy of Communist operation "in the labor movement of Sumatra, Borneo, New Guinea, Celebes, and Malay Peninsula, Burma, Siam, and Indo-China." ${ }^{33}$ After the consummation of the KMT-Communist united front, Communist parties and their affiliates in Southeast Asia were increasingly oriented toward the Chinese Communist Party. ${ }^{34}$ The Communist Party seized upon the anti-Japanese sentiment and nationalism of the Nanyang Chinese in order to gain control of non-Communist organizations. For instance, the Singapore Chinese League, organized to resist Japanese aggression, was taken over by Communists. ${ }^{35}$ Elsewhere in Southeast Asia after 1937, the Communist presence was felt in the Anti-Japanese National Salvation Movement.

The foregoing discussion of the KMT government relations with the Nanyang Hua-ch'iao communities reveals an extensive network that tied them both directly and indirectly to the fatherland. Although the KMT government's attempt to control every aspect of Nanyang Chinese communities was not always welcome, ${ }^{36}$ the revival of the KMT government's interest in the Nanyang Chinese was instrumental in increasing their nationalism and patriotism. As I will show, the anti-Japanese national salvation movement of 1937 needed no KMT prompting, a good indication that a sufficient national feeling for China already existed. As Professor Emerson once observed, the Nanyang Chinese were politically more conscious "than their fellows in China itself. ..."37 The time was ripe; the national sentiment of the Chinese people everywhere in Southeast Asia was reaching a climax on the eve of the Sino-Japanese war, which broke out in the early morning of July 7, 1937, at Marco Polo Bridge near Peking. The actors involved in the drama of the Chinese National Salvation Movement were 
the KMT government and their overseas agents; Nanyang Chinese communities and their organizations (such as the press, schools, and functional associations), at the apex of which stood the Chinese Chamber of Commerce; the local government; and the Japanese. I shall examine not only actions, reactions, and inter-reactions of these actors in the drama but also the motives and behavior of Nanyang Chinese in the National Salvation Movement, the extent of KMT control, and achievements of the Movement and its contributions to China.

I chose the period from 1937 to 1941 for this study for several reasons. First, the Sino-Japanese war was a major incident of historical significance for China. It was a terminal point in Sino-Japanese relations. It was also the first major war against Japan that Republican China fought with her back against the wall. China and her people for the first time appeared to be determined to fight the Japanese aggressor. Second, from 1937 to 1941, China fought single-handed against what appeared to be formidable odds. The war taxed her already meager financial resources. Remittances and contributions from overseas Chinese compatriots had been always one of the Chinese government's principal sources of revenue. No sooner had the war erupted than the government appealed to Chinese communities around the globe for more generous contributions. A study of the Nanyang Chinese response to China's call for patriotism during this period will answer stereotyped charges that overseas Chinese are money-minded and apolitical animals. Third, the period covered in this study is unique also because numerous Nanyang Chinese associations forgot their differences and agreed to form a central coordinating body in order to organize a more effective national salvation and boycott movement. For four years they carried out the campaign persistently. What drove them to act as they did? I hope to clarify the point in this study. Fourth, 1937 marked the beginning of the second KMT-Communist united front. I will attempt to analyze strategies by which the Communists infiltrated the National Salvation Movement, laying the foundation for the struggle of a Communist take-over.

Finally, a statement on stages in the development of the National Salvation Movement is in order. The period between July, 1937, and October, 1938, can be called the first stage. During these months, the National Salvation Movement was never centrally directed. It was 
directed by local leaders in various countries who showed no inclination to form a central body that would coordinate such movements throughout Southeast Asia and express to the Chinese government the wishes of its Nanyang Chinese compatriots. The period from October, 1938, to December, 1941, was the second stage. After the Nanyang Chinese had organized the Nanyang Chinese Relief General Association, the National Salvation Movement became more methodical, giving more emphasis to a systematic contribution and aid program. During this stage, relations between the Chinese government and Nanyang Chinese communities became strained largely as a result of the government's excessive meddling and corruption. By late 1940 or the beginning of 1941, the National Salvation Movement appeared to have ceased to be effective. However, the outbreak of war in Southeast Asia in December, 1941, revived the Nanyang Chinese national salvation spirit. 


\section{Chapter I}

\section{The Nanyang Chinese National Salvation Movement, First Phase (1937-1938)}

The Anti-Japanese National Salvation Movement of the Nanyang Hua-ch'iao which erupted in July, 1937, was the culmination of more than a quarter of a century of Chinese nationalism. In this campaign, devices and methods of the earlier anti-Japanese national salvation movements were employed and more effective tactics and strategies were added.

The "undeclared" Sino-Japanese war generated an unprecedented wave of nationalism and patriotism among the Nanyang Hua-ch'iao. They held protest rallies against the Japanese aggression and in cablegrams to Chiang Kai-shek and his soldiers at the front declared their unswerving loyalty to the Nationalist government of China. At the same time, they passed boycott resolutions against Japanese goods and organized relief-fund associations. Thirst for war news was unquenchable and feelings against Japan ran high, not only in cities but also in remote villages. Chinese in Pontianak, Borneo, for instance, kept their ears glued to the radio for war news from Hong Kong and Nanking. Chinese language newspapers ferried from Singapore three times a week were in demand, and the circulation of even a local Dutch daily shot upward. ${ }^{1}$ In the Philippine Islands, resist-the-enemy committees sprang up in villages where there were as few as ten Chinese. ${ }^{2}$

In this resistance movement, the Chinese Nationalists (later assisted by the Communists) played a more prominent and far-reaching role than in previous anti-Japanese drives. The KMT government utilized all available means to extract every ounce of energy and every penny the Nanyang Chinese could contribute. The government distributed reams of propaganda; increased both the power of transmitters beaming radio programs to Southeast Asia and the hours of transmission; sent out drama and music groups; and dispatched corps of boycott and picket leaders to organize clandestine anti-Japanese organizations with the assistance of local Chinese associations, particularly Chinese Chambers of Commerce, secret societies, and Communist groups. ${ }^{3}$ 
Having evidence of the KMT's active role in the campaign and of increasing penetration by Communists under the guise of the united front, local authorities became ever more apprehensive of the politicallyoriented Chinese. In the following pages, I shall examine the development of anti-Japanese activities country by country.

\section{The Straits Settlements and Malaya}

The Malayan-Chinese received the news of an exchange of shots between Japanese and Chinese troops near the Marco Polo Bridge with restraint despite inflammatory accounts in local Chinese newspapers. For ten days neither did the Singapore Chinese Chamber of Commerce take a formal action on boycott nor did the Chinese Consul General at Singapore issue a statement to Chinese residents. ${ }^{4}$ On July 17, the Chamber of Commerce met to deliberate the boycott question but took no action. ${ }^{5}$ On the following night, at a meeting of leading Singapore Chinese, the Consul General, Kao Ling-pai, who enjoyed the confidence of Chiang Kai-shek, begged them to "remain cool and not to boycott." Perhaps he counseled restraint because of the possibility of a peaceful settlement through negotiations. ${ }^{6}$ Both the Chamber of Commerce and the Consulate agreed that it was in their interest not to boycott Japanese goods while the situation was still in flux and while there was a chance for a cease-fire in north China; a common interest dictated prudence.

Only three days after the Consul General's plea, however, the fighting in China increased, and hopes for an amicable settlement dimmed. It now appeared likely that the Marco Polo incident would develop into general hostilities. ${ }^{7}$ Some hot-tempered Chinese stoned Japanese school children and manhandled a Japanese fisherman on the streets of Singapore. ${ }^{8}$ These assaults were the impulsive acts of a few irresponsible persons, not part of an anti-Japanese campaign. Nevertheless, after a few such incidents the British authorities issued a communiqué on July 24, enjoining both Japanese and Chinese residents to refrain from violence. The statement declared that the British government would observe a strictly neutral policy toward the two nationalities and that "it will not hesitate to exercise its authority against anyone who causes trouble." The government also asked both Japanese and Chinese publishers and editors to use special discretion and forbade 
both groups to solicit contributions to relief funds or to remit to their respective countries funds for military purposes. ${ }^{9}$

July passed without violence and boycott; presumably Chinese leaders were still discussing what course to take in response to the changing war situation. Then, in the first week of August, they decided to boycott Japanese merchandise and issued a secret boycott directive to various associations. In Ipoh, Muar, Malacca, Penang, Port Swettenham, and Perak, Chinese coolies refused to handle a shipment of Japanese goods, and Chinese resolved not to buy Japanesemade bicycles. In Singapore, Japanese physicians, dentists, barbers, and merchants were beginning to feel the results of the passive resistance of the Chinese. ${ }^{10}$ These boycott symptoms became noticeable about August 12. Who prompted the Chinese to adopt the clandestine boycott resolution-Chinese business leaders or the KMT government - has not been determined. Circumstantial evidence seems to support the argument that the KMT government urged Chinese community leaders to stage a boycott and that the latter agreed to cooperate for patriotic reasons. It is known that the KMT government secretly dispatched Ch'en Han-ming to direct a press campaign against Japan and consequently the Chinese-owned Malayan Tribune changed its editorial policy from neutrality to support of the KMT regime. ${ }^{11}$ The fact that Consul General Kao, who had counseled against boycotting, remained silent when the boycott began lends more evidence to the argument that the KMT government had prompted it. A member of Chiang Kai-shek's trusted circle, he could not do otherwise. It does not mean, however, that all of the Chinese leaders, let alone the Chinese residents, accepted the order with enthusiasm, as we shall see.

The deteriorating war situation roused the national spirit of the politically active Chinese. On August 15, the day the Japanese war planes bombed Wusung, Nanking, Hanchow, and Nanch'ang, Fukienese members of the Singapore Chinese Chamber of Commerce met and formed the Singapore Chinese General Association for the Relief of Refugees in China, and Tan Kah Kee, a long-time prominent businessman and the most active political leader of Chinese communities, became its president. It should be mentioned that Tan enjoyed an excellent personal relationship with Consul Kao and many KMT government high officials including the Generalissimo. Political and 
personal interests of the Nanyang Chinese leaders and the KMT government found a common ground, strengthened by an initial enthusiasm for the struggling Chinese government. Nanyang Chinese nationalism, which had long existed and which the KMT government had cultivated, had begun to sprout.

To circumvent the ban imposed by the British authorities, the Association ostensibly collected contributions to help refugees and bereaved families of the war dead. The Association assured the Colonial administration that the money collected would not be used for antiJapanese activities or for China's military purposes. Nevertheless, British and Japanese officials were skeptical. The British official source was reportedly wary because it could not ascertain how the funds would be used once the money was out of the British territory. Japanese Consul General Gunji Kiichi was positive, as he reported to Tokyo, that the money would find its way into the war chest of the Chiang Kai-shek government, ${ }^{12}$ for the real purpose was to "collect funds for the [national] salvation of China and to subscribe the National Salvation [War] Bonds." ${ }^{13}$

As the war turned to general hostilities, the boycott was sometimes enforced through intimidation. As in the past, the Hua-ch'iao were not without dissenters who, for various reasons, were unwilling to support the KMT's boycott directive. Chinese merchants continued to sell Japanese bicycles, the only ones available. These recalcitrant merchants had to be forced to support the anti-Japanese movement. Intimidating letters signed by the Red Blood Brigade were passed to their stores. "Do you have a conscience? Stop handling Japanese products immediately. Take this warning seriously," the circular reads, "or you will be sorry." ${ }^{14}$ It is clear from this episode that the KMT, even with its network and with the sympathetic cooperation of the Chamber of Commerce, could not command one hundred per cent patriotism from the Chinese. In this case it was the economic interests of this particular group of merchants that superseded patriotic commitment to the KMT government.

Generally, however, the Chinese took the anti-Japanese campaign seriously. In mid-August, a representative of the Nanyo Kyökai described the Chinese attitude toward the Japanese as "extremely unfriendly." "Th Their national sentiments were strong. The formation of 
the General Association evoked enthusiastic support for their motherland, the measure of which was indicated by the mushrooming of similar relief associations in cities throughout the Malayan peninsula. The Nanking government sought to take advantage of the surge of overseas Chinese nationalism by sending to Singapore a former Consul General of that city, Tiao Tso-ch'ien, to promote subscription to $\mathrm{Ai}$ $K u o$ Bonds. ${ }^{16}$ Tiao's arrival coincided with a conference of the All Malay District (Fukien) Hua-ch'iao Relief Fund-Raising Associations in the city on October 6. The fact that the Fukienese Hua-ch'iao, led by Tan Kah Kee, held the meeting on the day Tiao visited Singapore indicated harmony between KMT government agents and the Fukienese Chinese group. The assembly voted to divide the entire peninsula into twelve districts and to establish a new information office for the dissemination of propaganda and the promotion of bond subscriptions. The office was headed by Tan Kah Kee, who assumed the chairmanship of the entire fund-raising and anti-Japanese movement in Malaya. ${ }^{17}$

Another business magnate, Aw Boon Haw, a Hakka known in Malaya as the Tiger Balm King, organized his own fund-raising drive under the auspices of his daily newspaper, Sin Chew Jit Poh, and the Hakka Association. ${ }^{18}$ Evidently Fukien Chinese and the Hakka Chinese thought it unnecessary to unite in support of the Nationalist Chinese government. This apparent lack of coordination can be attributed partly to a long-standing rivalry between Tan Kah Kee and Aw Boon Haw and partly to the clannishness of the Chinese community. Aw Boon Haw's reason for organizing his own fund-raising campaign is not clear. In the Japanese study of influential Nanyang Hua-ch'iao, Tan Kah Kee was described as "the most prominent antiJapanese leader," but Aw Boon Haw was classified as only "a business leader" and in one study as "a pro-Japanese businessman," not one of the anti-Japanese leaders. ${ }^{19}$ Perhaps that is the reason that the Japanese military did not execute him after he was caught in Hong Kong and that the Japanese Kempeitai (gendarmerie) put a price on Tan Kah Kee, who hid in Malang, Java, during the Japanese occupation. ${ }^{20}$ Therefore, Aw Boon Haw's gesture appeared to be personal; he was conscious of his rival's patriotic activities. Aw Boon Haw's lukewarm political commitment or his disinclination to participate in political 
activities explain the fact that he played no prominent role in the National Salvation Movement. Clannishness is one of the weaknesses of overseas Chinese communities which discourages complete unity, ${ }^{21}$ as will be seen in the organization of the Nanyang Chinese Relief General Association formed in October, 1938.

Meanwhile, Chinese boycotting had become more intense and extensive. In mid-October there were reports of more than forty instances of Chinese picketing to keep Chinese, Indians, and Eurasians not only from Japanese stores but also from Indian and Arabian shops which were selling Japanese goods. ${ }^{22}$ In Singapore, Penang, Ipoh, and other places, Chinese landowners evicted Japanese tenants, raised rents arbitrarily, or refused to rent houses to Japanese. ${ }^{23}$ The boycott quickly made its impact on the owners of small and middle-sized Japanese shops. They were soon requesting extensions from their creditors, and several Japanese shops in the cities were facing bankruptcy. ${ }^{24}$

The anti-Japanese boycott presented special difficulties to the British authorities, for while they could not encourage action against a country with which Britain was on friendly terms, they did not wish to appear pro-Japanese. The problem of the government was to keep the balance between the two communities and to refrain from giving Japan an excuse for intervention in local affairs on the grounds of Chinese antiJapanese activity. Therefore, in late November, the British Colonial Office banned the importation from China of textbooks considered anti-Japanese in content, prohibited Chinese pupils from singing antiJapanese songs at school, and forbade Chinese residents to stage antiJapanese demonstrations. ${ }^{25}$

These measures appear to have been prompted partly by the evidence of Communist infiltration into the Chinese National Salvation Movement. The Communists had gained steadily in Malaya since the formation of the KMT-Communist united front in December, 1936, when Chiang Kai-shek was kidnapped by Marshall Chang Hsüehliang and released at the intervention of the Communists. The formation of the KMT-Communist united front "had . . . repercussions in Malaya." The Communists changed the names of their various groups "to suit the general anti-Japanese policy part; e.g., the General Labour Union now became the Labouring Classes Anti-Enemy-Backing-up Society." ${ }^{26}$ The Communists exploited the war between Japan and 
China by bringing "new recruits of their own" to the Chinese General Association for the Relief of Refugees, the supreme organization of the National Salvation Movement in Singapore. In order to foster antiJapanese feelings, the Communists formed two kinds of committeesone for open activities and the other for underground. To the former belonged the China Committee for the Eradication of Inferior (i.e., Japanese) Goods, the China Association for the Promotion of Chinese Goods, and the Chinese General Association for the Relief of Refugees. ${ }^{27}$ These organizations were created "to attract anti-Communists and members of other party organizations who would not have joined had they been aware of any Communist influence." 28 There were numerous Communist underground or front organizations which "became responsible for recruiting Communists amongst [their] members. ..."29 They included the Labouring Classes Anti-Enemy-Backing-up Society, the Malaya Anti-Enemy and National Salvation Corps for the Eradication of Traitors, the Chinese National Liberation Vanguard Corps, the Chinese National Reconstruction Corps, the Anti-Enemy Volunteers' Corps for the Eradication of Traitors, the Guerrilla Squad for the Eradication of Traitors, the Singapore Women's Classes Anti-EnemyBacking-up Society, and the Singapore All Chinese Classes Anti-EnemyBacking-up Society. All these illegal associations were controlled by the Malaya All Chinese Classes Anti-Enemy-Backing-up Society, which directed propaganda, contribution, traitor eradication, and boycott activities of its affiliated organizations. ${ }^{30}$ The Colonial police authorities had become increasingly sensitive to the rise of Communist influence in the National Salvation Movement. They arrested some members of the Chinese National Liberation Vanguard Corps as soon as it was identified as a Communist front organization. ${ }^{31}$

Japanese victories on the Chinese mainland, meanwhile, sharpened the edge of Chinese national feelings against the Japanese. In early December, when the fall of Nanking was imminent, anti-Japanese activities became more pronounced and widespread. ${ }^{32}$ During the week of December 13, when military operations against Nanking were at their height, one thousand Chinese coolies employed by the Ishihara Mining Company in Johore quit their jobs. As a result, the mining operation was paralyzed. Another mass walkout was reported at a Japanese-owned manganese mine in Trengganu. ${ }^{33}$ Terrorists frightened 
Chinese merchants who had placed Chinese labels on Japanese articles or sold them under the table. They cut off the ear of a Chinese merchant in Malacca and wrote threatening letters to many merchants. Similar terrorism occurred in Singapore when a Chinese fishmonger attempted to sell fish caught by Japanese fishermen. Some shops were smeared with filth because they dealt in Japanese merchandise. ${ }^{34}$ The outbreak of such labor strikes and terrorism was the direct result of a new policy that the Communists had adopted; they were responsible for organizing strikes and intimidation campaigns as well as demonstrations. ${ }^{35}$

A more ominous sign of Communist penetration of the Chinese National Salvation Movement was the Party's apparent readiness to play a commanding role in the Chinese anti-Japanese and anti-imperalist movement. As one Japanese observer saw it, although the British authorities were very firm in restricting Chinese anti-Japanese activities, they were soft in controlling Chinese economic protestation. The Communists, according to this interpretation, had concluded that the lukewarm British policy toward the Chinese derived in part from Britain's sympathy with China and from her fear of Japan's economic encroachment upon Britain's Southeast Asian market. ${ }^{36}$ Be that as it may, the first clear evidence of successful infiltration was a Communistinspired demonstration in Singapore on New Year's Day of 1938. Waving Chinese flags, chanting anti-Japanese songs, and distributing handbills printed with Communist slogans and signed by the Chinese National Liberation Vanguard Corps, several hundred Chinese marched through the streets toward a Japanese school where pupils were engaged in a New Year's Day ceremony. A clash with the Japanese was averted only by police action, which dispersed the demonstrators before they reached their destination. ${ }^{37}$

A second anti-Japanese demonstration organized by the Communists took place several days later when Sun Fo, the president of the Legislative Yüan of the Chinese Nationalist government, visited Singapore on his way to Europe. He stirred up the feelings of the Chinese residents with his ringing messages, and those who came to the pier to bid him bon voyage on January 6 were in volatile spirits. As they turned homeward, six trucks pulled up in front of the building of the Chinese Consulate General near the pier. Out stepped a large 
number of Chinese and a few Indians who began to distribute antiJapanese and Communist handouts to the well-wishers. They soon formed the milling Chinese into a demonstration, and the crowd marched through the streets, waving pennants inscribed with antiJapanese slogans in Chinese, English, and Hindi. The Police Commissioner ordered the demonstrators to disperse, and the police arrested a number of the Chinese and Indians who were distributing the literature. A mob of Chinese, however, returned that evening to the central police headquarters and demanded the release of the persons who had been arrested. When the constables refused, a brawl broke out; when it ended at midnight, 155 Chinese and one Indian had been arrested. ${ }^{38}$

Three days later the British authorities responded to the disorderly Chinese mob by banning all parades and meetings on the street, unless a special permit was obtained from the Office of the Police Commissioner. On January 11, the police raided several Chinese underground associations, including a printing shop controlled by the Chinese National Liberation Vanguard Corps. The raiding squads arrested three Chinese on charges of illegal activities and confiscated a volume of anti-Japanese and Communist propaganda literature. ${ }^{39}$

The riotous behavior, which resulted in a number of arrests and some bloodshed, dismayed KMT officials and the leaders of the Chinese community. The Association of the Fukienese Chinese, the Association of the Cantonese Chinese, the Chinese Chamber of Commerce, and the General Association for the Relief of Refugees all issued statements of regret, blaming for the riots a group of extremists who were trying deliberately to alienate China and Britain. Speaking for the entire Chinese community, Consul General Kao denounced the instigators as unpatriotic persons who "were attempting to disgrace the good name of the Chinese community, and their aim was to drive a wedge into relationship between the Colonial government and the Chinese." ${ }^{\prime 0}$ Strangely he did not refer to the Communists, whose role in the two recent agitations had been quite obvious, for the Communists and other left-wing underground groups that had planned, organized, and incited the mob were directly or indirectly connected with the very persons or organizations that had expressed the regret. For instance, the Malaya Anti-Enemy and National Salvation Corps for the Eradication of Traitors had been founded at the direction of Consul General Kao, ${ }^{41}$ 
and Tan Kah Kee and other prominent leaders, as already noted, maintained ties with clandestine KMT and Communist organizations. It seems that the anti-Japanese leaders had underestimated the hitherto moderate attitude of the British authorities, mistaking it for their sympathy to China. When the British administration responded with firmness, the KMT officials and Chinese leaders tried to absolve themselves from responsibility for the mob violence by placing the blame upon faceless "undesirable and extreme elements." These two incidents also reveal the fictitious reality of the KMT-Communist united front in action. The Communists were vying with the KMT for the control of the Chinese in the National Salvation Movement and were prepared to cooperate with the KMT only when they could advance the cause of the Communist Party; they were not to help strengthen the KMT but to embarrass and weaken it. The KMT, therefore, had a dual problem: how to deal with the Chinese community leaders to get their maximum cooperation, if not control of them, and how to cope with Communist subversion.

After the January incident, the British authorities were prepared to take whatever measures were necessary to contain the outburst of Chinese national feelings and to halt increasing Communist activities. That Communist influence was still on the rise was evident in the resolutions adopted by the Assembly for the Support of International Peace sponsored by the Chinese Chamber of Commerce. ${ }^{42}$ Such slogans as "Get Rid of Trotskyites," "Destroy Japanese Fascists," "Liberate the Chinese People and Win Freedom," and "Boycott Japanese Goods" were indicative that Communist influence and penetration were real. The Chinese were not daunted by the government's stern measures, though. Their anti-Japanese operation was executed by the "Ssu-fan," which had been used in the Tsinan incident boycott in 1928. This punishment of recalcitrant members of a guild association, characteristic of the power of the Chinese guild over its members, "rested upon the doctrine of responsibility which was highly developed in traditional China." ${ }^{43}$ The severity of the punishment increased as offenders repeated the violation of boycott rules or persisted in conduct unacceptable to the guild. The first offense was punished by fine, chastisement, or obligatory public apology; the second by smearing the offender's store with coal tar, filth, or human excrement; the third by ear-cutting; 
and the fourth by death. The third and the fourth were designed to extort money from non-cooperative members, and the forced contributions were put into the war chest of the Chinese government. ${ }^{44}$ During 1938, it was reported that countless Chinese received the first warning, about six hundred stores were smeared, twenty-five persons had their ears slashed, and thirty persons were murdered throughout Malaya. ${ }^{45}$ Moreover, members of the Malaya Anti-Enemy and National Salvation Corps still kept vigilance over Japanese stores and physicians to prevent Chinese patronage despite warnings issued by the British authorities. ${ }^{46}$ An alarming degree of Communist infiltration into the Chinese National Salvation Movement appeared to be the reason for another ordinance issued by the Colonial government on March 4, which forbade the Chinese to hold meetings, parades, or musical concerts in the street. The decree gave power to constables to break up unauthorized gatherings and parades and provided for criminal prosecution of violators. ${ }^{47}$ The stiffened British policy was demonstrated by the swift arrest on April 30 of seventy-three leftwing Chinese coolies and laborers who were holding an unauthorized meeting to plan a May Day demonstration against the Japanese. ${ }^{48}$

Rather than weakening the national spirit of the Chinese, the British police action and a stream of discouraging war news from China invigorated it. In the early summer of 1938, the Japanese troops captured Amoy, the home of the Nanyang Hua-ch'iao, and their airplanes bombed Canton, Swatow, and Hainan Island. The news stirred up new Chinese hostility toward the Japanese. On June 5 and 25, large numbers of Chinese, mostly Hainanese, staged anti-Japanese demonstrations in Singapore and the peninsula in defiance of the British ordinance. Constables in Singapore arrested scores of the demonstrators, who waved Chinese flags and chanted anti-Japanese songs. ${ }^{49}$ AntiJapanese feelings were also high in Penang, Malacca, and Kedah, where Japanese doctors, barbers, and laundrymen had been systematically boycotted, and the Japanese were braced for worse in the months to come. $^{50}$ The emotions of the Chinese were growing more intense as the first anniversary of the Sino-Japanese war approached, and the atmosphere throughout the British territories was one of fear that something would happen at the slightest provocation.

The fears became reality on July 3, when a riot broke out in 
Penang. ${ }^{51}$ The Penang revolt was touched off when pickets caught a Chinese secretly purchasing soy beans from Japanese-controlled Manchuria. The discovery brought a mob of several hundred persons to the hapless man's store, which they ransacked and destroyed, dumping twenty bags of soy beans into the street. The outrage of the local Chinese was transformed into violence as night advanced. By the following morning, a reign of terror and near anarchy had gripped the city. Chinese stores whose owners had been suspected of having dealt in Japanese merchandise were plundered by mobs, and goods were indiscriminately destroyed in a rain of rocks, stones, coal tar, and sulphuric acid. The defiant crowd attacked police contingents dispatched to quell it, and appeals from the Chinese consul in Penang to restore order fell upon deaf ears. The pillage continued throughout July 4 and 5 , and a number of stores and factories were set afire. Finally the British authorities sent a small force of troops to assist the policemen in coping with the "anarchic" situation. Four days of strict law enforcement brought the riot under control and resulted in the arrest of eighty insurrectionists.

Throughout Malaya the approach of July 7, the anniversary of the Sino-Japanese war, threw the Japanese community into near panic. Anticipating Chinese violence, the Japanese community leaders alerted all Japanese residents and closed Japanese schools to protect the children. The Singapore police headquarters, at the request of Japanese officials, reinforced police patrol for an emergency. ${ }^{52}$ To the great relief of everyone, the Double Seven anniversary passed without a serious incident in Singapore, Johore Bahru, Kuala Lumpur, or Seremban. In Singapore a few members of the Liberation Vanguard Corps distributed Communist leaflets but without effect, and in Taiping a half-dozen Chinese terrorists broke into a Chinese shop suspected of having purchased Japanese goods. ${ }^{53}$

The Penang riot stunned the Chinese leaders in Singapore. Immediately upon receipt of the news, Tan Kah Kee convened a meeting on July 7 to see what could be salvaged from the incident, which he said marred "friendly relations between Britain and China." The patriarch appealed to all Chinese, particularly students and youths, to be more prudent or they would make the Chinese "a laughing stock." In his admonition, Tan painfully pointed out the importance of main- 
taining cordial relations with Britain, without whose aid China could "not keep the war of resistance going. ..." "The patriotic Hua-ch'iao," he reminded his compatriots, "must bear this fact in mind." 54 This statement is of interest in view of the fact that his memoirs, from which it is quoted, were written in 1946, by which time he is known to have been leaning towards Communism. By deliberate omission, Tan did not mention the active role of the Leftists and Communists in many anti-Japanese activities.

A week after the Double Seven anniversary day, the British authorities issued a communique aimed at the Chinese. The statement bluntly warned them that the government would henceforth deal sternly with those who organized and incited riots under the pretext of a patriotic movement. ${ }^{55}$ The terse and straightforward enunciation of the policy had a moderating effect on the Chinese for the time being. No serious incident occurred for the next four weeks, though several minor incidents, such as defacing stores with coal tar and slashing of ears, were reported in the last two weeks of July. ${ }^{56}$ The outward appearance of calm did not last long, however. On August 17, the Colonial government announced the arrest of the Wang Yen-chih, a cadre of the secret Anti-Enemy Volunteers' Corps for the Eradication of Traitors, and Chan Wen-hua, general director of the Malaya All Chinese Classes Anti-Enemy-Backing-up Society, on the charge of Communist activity. ${ }^{57}$ The next few days witnessed protest demonstrations and sympathy strikes, which spread to Kuala Lumpur, Ipoh, and Penang. The persistent Chinese agitation not only endangered Britain's relations with Japan, which Britain was anxious to maintain in peace, but also irritated the British. The Singapore police force consequently cracked down on both registered and unregistered Chinese societies; the police arrested twenty-two terrorist members of secret societies, ordered the dissolution of the Youth Le-hsin she on the grounds that it had participated in political activities, and issued a warning to eighteen registered Chinese associations for having actively engaged in the anti-Japanese movement. ${ }^{58}$

Not only did the Chinese exhibit their support for China's fighting cause in the boycott movement, but they also donated a considerable amount of money to the government of Chiang Kai-shek. Money was raised by various methods characteristic of the Chinese. It is instructive 
to examine the ways funds were collected in order to see the extent of the control of the guild over its members and to see reactions of the Chinese to the campaign.

Upon the outbreak of the Sino-Japanese incident, Chinese in Malaya spontaneously raised funds for the relief of their compatriots in China. Donations to China were systematized by the formation of the Singapore Chinese General Association for the Relief of Refugees in China on August 15. In October, similar associations were also established in Malacca, Penang, Pahang, Negri Sembilan, Perak, Selangor, Kedah, Johore, Perlis, Trengganu, and Kelantan. In order to coordinate the operation of the fund-raising drive, the Information Office of the Federation of Malaya Chinese Relief Fund Raising Association was established within the office of the I-ho-hsüan Club, one of the command posts of the Chinese anti-Japanese campaign. ${ }^{59}$ The Information Office was merged with the Malay Office of the Nanyang Chinese Relief General Association when the latter organization was set up in October, 1938. Tan Kah Kee served concurrently as chairman of the Malay Office and its mother organization. In short, he was general chairman of the money-raising operation throughout Southeast Asia.

A study of the Singapore Association, prototype of the fund-raising organization, shows how the system worked. ${ }^{60}$ The Singapore Association was headed by Tan Kah Kee, assisted by vice-chairman Lee Kong Chian, chairman of the Singapore Chinese Chamber of Commerce and Tan Kah Kee's son-in-law. The thirteen members of the standing committee were elected by a committee of thirty-one persons who represented the city's guild associations. Of the thirteen, according to Japanese intelligence studies, five were definitely identified as very active in the anti-Japanese movement. ${ }^{61}$ Tan Kah Kee was in charge of the Association's two most important committees, the committee for bond solicitation and the committee for contributions. The Association almost arbitrarily alloted a quota for bond subscriptions to member organizations and wealthy individuals, and it devised a method for the efficient collection of money as well as a monthly contribution system. For their operation, an influential person was selected for each speech pang (group) and charged with the responsibility of raising funds in his pang. $\mathrm{He}$, in turn, formed a committee and supervised its fund- 
raising within the pang, which was scattered throughout the city. No Chinese could possibly escape the network of the fund-raising machinery, for the Association had an office in each district of the city. Within each office were sub-offices set up for professional guilds, such as those of seamen, railway workers, retail businessmen, and workers employed by foreign firms. These sub-offices were further split into smaller units according to speech pangs (Fukienese, Cantonese, Hakka, Teochiu, and Hainanese) and other groups, such as women and Babas (local born Chinese).

Since the British authorities restricted fund-raising to collecting for relief, the Association was unable to conduct other anti-Japanese activities such as propaganda, boycott and use-Chinese-goods drives, help native-provinces drives, and fund raising for airplanes and soldiers. These campaigns were run by the Chinese Aviation Society's Malay Office (Consul General Kao was its chairman), the Chinese Women's Association for Comforting Fighting Soldiers (Mme. Kao was its chairman), and other groups with whom the Association maintained close ties.

Contributions to China's war chest were raised by a wide variety of means besides regular monthly donations. The most common were special contributions on important national holidays, ostensibly for the relief of victims of natural calamities; import duties and surtax on items purchased overseas; ${ }^{62}$ extra donations on memorial days (the Chinese New Year, the anniversary of Sun Yat-sen's death, the anniversary of the Huang Hua Kang Revolt, the May 9th National Humiliation Day, the Marco Polo Bridge Incident on July 7, Resistance Day on August 13, Manchurian Incident Day on September 18, the Double Ten National Holiday, Chiang Kai-shek's birthday on October 30, Sun Yat-sen's birthday on November 12, and the Yunnan Revolt Day on December 25); flower and medallion sales on these memorial days; proceeds of drama and stage shows; campaigns for curtailing temple worship expenses; and the setting up of donation boxes in public places. Between August, 1937, and August, 1938, the Malayan Chinese collected $19,900,000$ yuan, of which $5,700,000$ yuan was credited to Chinese in Singapore, according to a Chinese source. ${ }^{63}$

In order to institute a monthly contribution system so as to insure a flow of money into the Chinese government treasury, the Singapore 
Chinese General Association for the Relief of Refugees, at the request of the KMT government, drew up new regulations, effective on May 1, 1938. Singapore was divided into six pangs, and contribution solicitors collected donations according to a check list prepared by the Association. The solicitors would secure signatures of donors and also report for newspaper publication the names of persons who refused to subscribe the quota. A monthly quota assigned to factories, firms, shops, and banks was classified into thirteen categories according to ability to pay. For the special category there was no ceiling; for the first, the quota was five hundred yuan and for the twelfth, five yuan. A quota of one-hundredth of their monthly income was prescribed for shop clerks, blue-collar workers, and free workers. Such arbitrary quota allocation infuriated many Chinese.

The bond subscription campaign was conducted in the same methodical fashion, and the Malayan Chinese bought bonds worth $12,800,000$ yuan; of that amount, the Singapore Chinese accounted for 4,550,000 yuan between August, 1937, and August, 1938. ${ }^{64}$ However, these contributions and subscriptions were reported to be unsatisfactory to Tan Kah Kee. Figures for contributions raised by the Chinese Aviation Society and the Chinese Women's Association for Comforting Fighting Soldiers were not available. Tan Kah Kee reported that the latter organization had involved itself in a factional strife with the Women's Affairs Section of the Singapore Chinese General Association for the Relief of Refugees, with the consequence that Mme. Kao's association managed to raise only a few hundred thousand yuan. ${ }^{65}$

Japanese sources admitted that the response to these contribution devices was lively, particularly in the early months of the war. ${ }^{66}$ The fervor, however, began to subside partly because of resentment against the arbitrariness with which the quotas were alloted and the moneys collected and partly because of a drop in the prices of rubber, copra, and tin. The new regulations for monthly donations appeared to be extortion in disguise. Chinese had two choices: to give or to refuse and have their names published in newspapers. As a result, many Chinese aired their protests in newspapers, charging that the Association acted "as if it had granted an authority to the KMT government to tax Malayan Chinese." ${ }^{\prime 67}$ In the midst of the uproar, Tan Kah Kee resigned as chairman of the Committee for Bond Subscriptions without 
an explanation, raising speculation that contributions in the first quarter of 1938 had not been satisfactory, that he had resigned in order to end criticism directed at him for introducing the new monthly giving regulations, or that he had quit because within the committee there was constant factional strife between the Fukienese and the Cantonese. $^{68}$

The Chinese National Salvation Movement in the British territories became the model for anti-Japanese campaigns in other Southeast Asian countries. For this reason I have described in detail its activities in order to illustrate the extent to which the Chinese reacted to the aggressive action of the Japanese on the Chinese mainland. The foregoing discussion shows the manifestation of their intense feelings. Its scale and dimensions were unprecedented. Chinese throughout the British possessions were kindled by the flame of national spirit to obstruct Japan's economic activities in Malaya and to back up the Nationalist government of China. Methods used in the campaign had changed little, but the KMT was participating actively, both openly and in secret. To the British a sign more ominous than active KMT involvement was the evidence that the Communists had successfully infiltrated the movement. Many factors contributed to this enthusiastic response of the Malayan Chinese: (1) the demographic distribution of the Chinese, who constituted 41 per cent of Malaya's total population, and the presence of a large number of Hainanese, who were susceptible to leftist propaganda because of their low social status; (2) the steadily deteriorating war situation in China and the spread of the hostilities to South China, with which the Chinese had strong emotional ties; (3) the Hua-ch'iao's realization that a threat to China was a threat to them; ${ }^{69}$ and (4) the existence of good working relations between the KMT government and local Chinese groups, especially the Chinese Chambers of Commerce, based on common interests and objectives.

That is not to say that the Chinese National Salvation Movement was free from problems of boycott enforcement and coordination and factionalism. The fact that members of the Red Blood Brigade and other terroristic societies had to be recruited and the Ssu-fan frequently employed for intimidation in order to enforce the boycott upon reluctant Chinese suggests neither total KMT control of the Chinese community through local agencies nor total loyalty to the Chinese govern- 
ment. Indeed, KMT guidelines for the movement aroused resentment among Chinese who did not want to be compelled to contribute. Small merchants, for economic reasons, although appearing to follow the boycott movement for fear of reprisal, traded under the table with the Japanese or paid boycott enforcement agents to overlook their dealings in Japanese goods. The boycott put them in an uncomfortable position; KMT agents and the local Chinese hierarchy urged them to boycott, and British authorities urged them not to boycott. Either choice meant economic privation. Chinese more interested in money than in politics chose the middle ground so as to maintain their facade of boycott cooperation and, at the same time, sustain their business and livelihood. Because of their limited capital, they could not afford to close their businesses regardless of nationalism's demand for their sacrifice.

The KMT-Communist united front produced little coordination in the movement. The Communists competed with the KMT for influence and leadership. Their revolutionary leadership in the January and July affairs aroused British suspicion about the intent of the KMTled National Salvation Movement, making it more difficult to carry out anti-Japanese activities. The Communists tried to embarrass the KMT, while appearing to work with it when cooperation would enhance their own position.

Another serious problem in the movement was that of factionalism. Rivalry between Tan Kah Kee and Aw Boon Haw, between the Fukienese and the Cantonese, and between individuals for reasons of personal enmity and business competition weakened the effectiveness of the National Salvation Movement. The Hua-ch'iao community was not a cohesive society; it had too many groups with varied interests. Even a national crisis, the Sino-Japanese war, did not bring them into total unity.

Although British policy toward the Chinese National Salvation Movement became more and more stringent because terrorism frequently accompanied the movement, ${ }^{70}$ it should not be considered anti-Chinese. Britain's position is not difficult to appreciate. She was obliged to maintain law and order in Malaya's multi-racial society and could not permit the Chinese to disrupt the racial peace simply because they regarded Japan's policy as obnoxious. Britain was not at 
war with Japan; and because she wished to maintain good relations with China, she was anxious to avoid diplomatic complications which would give Japan an excuse to interfere in local affairs. Moreover, the British police knew that Communists, under the cloak of the KMTCommunist united front, were using the National Salvation Movement to infiltrate labor unions. These appear to be the motives behind Britain's attempt to contain the Chinese National Salvation Movement. The number of arrests and fines imposed upon Chinese in the first twelve months after the outbreak of the Sino-Japanese war suggests the severity of the British authorities. A conservative estimate was 37 persons arrested, 122 fined and 18 imprisoned. ${ }^{\mathbf{7 1}}$

\section{The Dutch East Indies}

The initial response of the Indies-Chinese in Java to the Marco Polo Bridge incident, unlike that of Chinese in British territories, was described by both official and unofficial local Japanese sources as "calm," "passive," and "restrained." ${ }^{2}$ There was no sign of a boycott movement throughout July, and even in late August there was relative calm. Nowhere were there signs of a boycott in the other outer islands of the Indies. Reports from Palembang and Medan in Sumatra; Bandjermasin in Borneo; Manado, Gorontalo, and Makassar in Celebes; Ternate in Halmahera; Ambonia in Ceram; Dobo in Aroe; Manokwari in New Guinea; and Ampenan in Lombok suggested that the Chinese were not ready to stage a boycott movement. Only Pontianak in Borneo and Tandjoeongbalai in Sumatra, where Cantonese were numerous, reported that Chinese national spirit was high and that Chinese residents in these cities had started an unorganized boycott drive. ${ }^{73} \mathrm{Na}$ tional spirit was high in both cities because of regular boat service between them and Singapore, large numbers of Chinese (70 per cent of Pontianak's population and 50 per cent of Tandjoeongbalai's), and Chinese economic dominance. The Cantonese were predominantly lower-class laborers, and 40 per cent of them were Sinkheh (Chinaborn Chinese). The Cantonese were also strong in journalism and education; therefore, they were susceptible to political events in China. ${ }^{74}$ Only after the Sino-Japanese hostilities spread to central and southern China did Chinese enthusiasm for the National Salvation Movement begin to gather widespread strength. However, it was 
directed towards a contribution campaign, not a boycott drive, about which the Chinese were undecided. On August 2, the Chinese leaders of Batavia organized a Batavia Hua-ch'iao Charity Committee for the Relief of China and resolved to carry out an anti-Japanese program. Tjong See-gan, a Fukienese and a member of the KMT Legislative Yüan, became its first chairman.

Stimulated by the example of the Batavian Chinese, the Chinese in other cities in Java and the outer islands set up similar committees. The Charity Committee was divided into sub-committees, each responsible for copra donation, contribution boxes, monthly savings, jewel contribution, drama and stage shows, frugality campaigns, athletics, and women's affairs. The Batavia Charity Committee, in cooperation with the city's Chinese Chamber of Commerce, for example, sponsored a night market and raised 20,000 guilders, and encouraged rice merchants to contribute two cents for every one hundred kilos of rice they traded. In these ways, the Committee was able to collect 1.4 million guilders by October, $1938 .^{75}$

Following the example of the Malayan-Chinese, the Charity Committee solicited extra donations on national holidays and memorial days and small contributions from school children by placing donation boxes in Chinese associations and schools. In response to the KMT government guideline, the Charity Committee instituted the monthly contribution program beginning in May, 1938. In Batavia the operation yielded more than 130,000 guilders by the end of 1938. In the donation drives, the Charity Committee emphasized the collection of medicine, especially quinine, a Dutch East Indies product. In September, the Charity Committee sent 17,000 guilders' worth of quinine, and by the end of 1937, it had sent 120,000 guilders' worth. ${ }^{76}$ According to an official Chinese source, by the end of 1937, all the IndiesChinese had sent quinine to a customs value of one million dollars. ${ }^{77}$ At the request of the KMT government the Charity Committee launched the bond subscription campaign in September, 1937. The campaign required a bit of ingenuity to circumvent a Dutch government ban on newspaper advertisement for bond subscription. The Committee followed the chain letter system, a practice employed by the Chinese on the mainland to solicit subscriptions during the Manchurian incident. Although the principle was that of the usual chain 
letter, this letter came from a friend, not a stranger, and directed the recipient to buy war bonds, not to send money. A typical letter read as follows:

In order to achieve objectives of the National Salvation Movement, you who receive this letter must buy more than five guilders of National War Bonds. You must faithfully carry out this request and write nine letters to your trusted friends. Should you fail to execute these within the next twenty-four hours, a misfortune may fall upon you.

The person receiving this letter would buy bonds and report to the Charity Committee his having received the letter and bought bonds. This clever method of subscription to outwit the government was said to be particularly successful in Batavia and Surabaya. The Charity Committee was able to report that the Chinese in Java had subscribed more than 1.25 million guilders by September, $1938 .^{78}$

Although the Chinese undertook these contribution campaigns, they hesitated to launch an organized boycott. Not until September did the Overseas Chinese Bank in Batavia, the only bank in the Indies authorized to transact foreign exchange, issue a policy statement that it would henceforth cease to correspond with Japanese banks. ${ }^{79}$ Some wealthy Chinese in Surabaya were reported to have been withdrawing their savings from Japanese banks and either transferring them to Chinese banks or sending them to Singapore. ${ }^{80} \mathrm{~A}$ few incidents of coaltarring Chinese shops specializing in Japanese merchandise occurred in October, apparently provoked by Japanese bombings of southern China. ${ }^{81}$

Meanwhile, the Dutch authorities had been enforcing very strict strike laws upon the Chinese and prohibiting political activity. Already, some Chinese language newspapers had been either warned or suspended temporarily for having printed articles derogatory to Japan, and teachers were kept under close surveillance. Teachers who persisted in teaching anti-Japanese lessons were expelled from the territory as persona non grata. Immigration officials had been maintaining tight security to prevent the entry of KMT agents and other agitators who might slip in from the British territories. Furthermore, the Dutch government prohibited all forms of contribution except to the Red Cross Society and to charity, censored movies relating to the Sino-Japanese war, and banned the import of anti-Japanese texts and books, a 
list of which was published in an official bulletin. Whenever intimidations of Japanese residents were reported, the police made a thorough search to ensure the protection of Japanese lives and property. ${ }^{82}$ These steps were consistent with the past Dutch policy toward the Chinese, whose political movements had long been a matter of grave concern to the colonial administration; the Dutch feared that the politically oriented National Salvation Movement might arouse the forces of an indigenous nationalist movement.

Despite this firm Dutch policy, the Chinese finally resolved to boycott Japanese goods in the second week of October, shortly after the puasa, a Moslem religious month for fasting, when their warehouses and stores were well stocked with Japanese merchandise. On October 12, the Chinese Importers' Association of the Netherlands Indies adopted boycott resolutions to "cancel all existing import contracts with Japan" and to "purchase Chinese products." It was not yet, however, an all-out boycott. The Association, for instance, permitted its members to sell Japanese merchandise on hand, to honor import contracts which were "difficult to cancel," and to conclude by November 21 import contracts with the Japanese. ${ }^{83}$ Leaders of the Association were apparently mindful of the stern attitude of the Dutch government toward boycott and were also aware of the disadvantages of severing business relations with the Japanese. Japanese sources interpreted these rather mild boycott resolutions as a sign of Chinese economic weakness and vulnerability. "Chinese merchants in Java," said Arimoto Takeshi, manager of the Bank of Taiwan at Surabaya, "agreed not to buy Japanese goods, because they had a surplus of Japanese merchandise in stock that they had imported during prosperous months in the spring of 1937. In order to clear the accumulated goods, a majority of Chinese merchants decided to refrain from buying Japanese products." ${ }^{84}$ Arimoto's statement implies that the boycott was a business expedient, not a deterrent, to Chinese merchants; once they had sold their surplus stocks of Japanese goods, they would buy more. If direct dealing with Japanese importers proved risky, they would buy from Dutch wholesalers. ${ }^{85}$ According to another observer, the Chinese launched the boycott after the puasa, not before it, because Japanese goods were in demand during the Islamic religious month. The merchants waited until they had stocked a supply of Japanese products. That observation 
emphasizes the economic expediency of the boycott. ${ }^{86}$ The point of the second observer is that this boycott was a self-centered movement calculated solely by dollar-and-cent economic motives. Such interpretations are debatable. Judging from the past record of boycotts in the Dutch Indies, it is possible to argue for the Japanese contention. To accept it wholly, however, is a gross exaggeration of the so-called business-as-a-matter-of-life mentality of the overseas Chinese. Indeed, many Japanese observers minimized Chinese political consciousness and nationalism. ${ }^{87}$ Perhaps the Chinese boycott was a token to save face under pressures of the KMT government. The KMT could exert pressure on the Chinese leaders but could not force them to an all-out boycott in which Chinese merchants would risk the economic positions that they had laboriously built. If this interpretation, which statistical evidence supports, is correct, the Chinese community and the KMT government did not agree on the boycott question, although they seemed to agree on the contribution campaign.

The Chinese found it difficult to maintain an effective boycott in the Netherlands Indies, partly because of the vigorous repressive policy of the colonial authorities, partly because of a sluggish economy, and partly because of their selfish economic interests. As Arimoto observed, Chinese merchants were reported, with increasing frequency, to be dealing with Japanese firms either clandestinely or through a Dutch intermediary. For instance, in Batavia the Association of Chinese Cotton Cloth Merchants resolved to effect a voluntary boycott of Japanese cotton products on December 13, the day Nanking fell into Japanese hands. The resolutions contained such stringent provisions against buying Japanese cotton goods that members could not buy them from either the Japanese or Dutch and Indian merchants. It was obviously an attempt to plug loopholes which permitted merchants to continue to buy Japanese cotton goods. A week after the fall of Nanking, Chinese retail merchants declared their readiness to suspend dealing in Japanese merchandise. All these aroused national feelings, however, began to cool as the Indies' export trade stagnated and purchasing power declined. Many Chinese wholesale cotton merchants in the city had stocks of Japanese cotton products which they could not sell. Consequently, in February, 1938, the Chinese merchants retracted their boycott declaration in order to clear their stock. 
On the other hand, Chinese merchants continued to boycott other Japanese goods, which became more and more scarce in early summer. Unable to make their living as a result of the five-month old boycott, Chinese wholesale and retail businessmen got Japanese merchandise either from European firms or directly from Japanese companies and replaced Japanese labels with European. Economic necessity forced the Chinese to deal secretly in Japanese goods despite pressure from the KMT. A KMT sponsored Sino-Japanese incident anniversary rally on July 7, at which Consul General Ko Tsu-k'uang spoke, did not evoke an upsurge of patriotism in the Chinese audience. ${ }^{88}$

At Cheribon, Bandoeng, and Serang in western Java, there were no serious boycotts, and the National Salvation Movement confined itself to the fund raising campaign. Even when Amoy fell to the Japanese in May, 1938, the predominantly Amoy Fukienese Chinese in Bandoeng were not particularly agitated by the news. ${ }^{89}$ The Chinese boycott in the Jogja-Solo area and Semarang was also reported mild. However, the boycott against Japanese shops was effective enough to compel local business leaders like the Lie Ngo An family, Lie Kiem Tjoan, and Kwee Bok Ai, who were known to be sympathetic toward the Japanese, to avoid doing business with them for fear of reprisal. In Semarang, the 27,000 Chinese, eighty per cent of whom were Babas, maintained relative calm in the boycott movement until the Cantonese Sinkheh agitated for boycotting. The Sinkheh, many of whom were intellectuals (teachers and journalists) and skilled tradesmen (carpenters, hardware shop owners, accountants, restaurant owners, and cooks), dragged the apathetic Fukienese-Babas into the struggle. There were several coal-tarring incidents and the bankruptcy of a Japanese shop in the early months of the campaign, but after April or May, 1938, even the intimidation of the Cantonese could not deter the Chinese from doing business with the Japanese. Japanese sources were optimistic about business in Semarang. ${ }^{90}$

Like most of the Chinese in Bandoeng, the Chinese in Semarang were Babas of the third and even the fourth generation, whom the Cantonese looked down on as "having lost their 'Chineseness.' " They were Indonesians first and Chinese second; to them, events in China were more remote than to the Cantonese Sinkheh. They had little reason to support Chinese nationalism; they regarded the Dutch Indies 
as their homeland and spoke Indonesian and Dutch more fluently than Chinese. Having been educated in Dutch government schools, many had become "Dutch minded." patriotism of the Fukienese, who constituted over 90 per cent of all Chinese born in Indonesia. Thio Thiam Tjong, a Baba-Fukienese leader of Semarang, deserves mention. He took a major part in the National Salvation Movement, raising funds and giving moral support to the KMT government. When the Japanese occupied Semarang, the Japanese Kempeitai imprisoned him and demanded that he divulge "information about others connected with China aid funds. . .." Even the Kempeitai's torture did not break his strong will, and he took "full responsibility" for the anti-Japanese movement. ${ }^{92}$

In Surabaya, where there were 40,000 Chinese, boycott effects on Japanese trade were inconsequential because the principal patrons of Japanese stores were the more than 250,000 Indonesians, not the Chinese. Even during the boycott, Chinese wholesalers and retailers dealt in Japanese goods with little hindrance from intimidators. In November, the Chinese press tried to promote an anti-Japanese campaign but failed.

In the outer islands, only Pontianak, Borneo, organized a successful boycott. There was no systematic boycott in Medan, Palembang, Padang, Makassar, Manado, Ceram, Halmahera, Aroe, or New Guinea. $^{93}$ So effectual was the Pontianak boycott, however, that no Japanese merchandise could reach a district of the Kapoeas area near the city without a police escort because the Chinese controlled both land and river transportation. ${ }^{94}$

Meanwhile, Dutch authorities kept a close watch over the Chinese. When the Association of Chinese Cotton Cloth Merchants declared a voluntary boycott of "inferior goods," effective on December 13, 1937, the Dutch police apprehended Tjong See-gan, ${ }^{95}$ its prime promoter, and more than a dozen leaders, apparently at the request of the Japanese consulate. According to official information, ${ }^{96}$ Japanese consular officials had an unconfirmed intelligence report of the arrival of KMT members dispatched by the Chinese government to agitate behind the scenes and to promote a boycott. After the declaration of the boycott by the Association of Cotton Cloth Merchants and two assaults upon Chinese merchants, the Japanese officials presented the evidence to the 
Attorney General with a request for more rigorous enforcement of the Public Peace Regulations upon Chinese boycotting. The Attorney General promised to administer justice but requested that for security reasons the Japanese not divulge the agreement. ${ }^{97}$ The result was the roundup of the boycott leaders. The police detained Tjong for several hours for questioning about his connection with the assaults and the boycott declaration. Although the police failed to extract conclusive evidence of his complicity, the arrest of the boycott leaders created panic among boycotting merchants and helped prevent further interference with Chinese merchants doing business with Japanese or dealing in Japanese goods. ${ }^{98}$ When several Chinese stores that handled Japanese cotton goods were smeared with coal tar, Dutch authorities took prompt action, again at the request of the Japanese. Frequently, the Dutch suspended publication of several Chinese dailies for having printed inflammatory articles and advertisements. In May, publication of the Thien Sung Jip Po of Batavia and the Ta Kong Siang Po of Surabaya was suspended for two weeks on the grounds that their editorials were anti-Japanese. In July, publication of the Sin Po, the largest Chineseoperated daily in Batavia, was suspended eight days for having printed anti-Japanese articles. For the same reason, the publisher of the Keng $P o$ of Batavia was reprimanded and the publication of the Sumatra Min Po of Medan suspended..$^{99}$ Finally, the Dutch administration prohibited "public auction or propaganda for the sale of war bonds,"100 although it authorized Chinese banks to sell Chinese bonds.

To sum up, the effectiveness and scale of the National Salvation Movement conducted by the Indies-Chinese cannot be compared with that of its counterpart in Malaya. Japan's economic losses from the boycott were not serious, although in some places where the Japanese retail network was weak, Japanese merchants experiencd great difficulty. The boycott had some telling effects on Chinese businessmen who dealt exclusively in Japanese merchandise. Generally speaking, Japanese trade in the Indies suffered only slightly in large cities and towns, thanks to the natives' constant demand for Japanese goods they could afford. ${ }^{101}$ Although the boycotts produced no spectacular effects, the fact remains that the Indies-Chinese organized the campaigns and committed themselves to the boycotts for some months. Furthermore, their contributions of money and drugs offset the ineffectual boycotts. The 
emphasis on donation drives may well have been the result both of economic interests and the tight control the colonial authorities exercised on the boycott campaign. Under the circumstances, the Chinese boycott leaders may have concluded that they could do more for China by emphasizing the contribution campaign instead of carrying out a boycott whose results would be ineffectual. Nonetheless, their national consciousness would not permit them to sit idly by while Chinese in other parts of the Nanyang were boycotting. Boycott was a more concrete and direct way than contribution to demonstrate their national feelings. Their national and racial pride as well as their mien-tzu (face) was too important to permit them to remain idle in the time of China's national crisis.

Nevertheless, one cannot help admitting the internal weaknesses of the Chinese community, stemming from the demography of the Chinese ethnic groups in the archipelagoes and from a lack of cohesiveness. The Chinese population was decisively a minority group. A boycott by a minority group, when the police were strict and most of the native population wanted to buy Japanese goods, had little chance for success. The Chinese society in the Indies never had been a cohesive community. It was ridden with factionalism between speech groups and with social distinctions between Babas and Sinkhehs. Fukienese and Cantonese-Hakkas, as in Singapore, were competing for power, For instance, relations between Fukienese and Cantonese-Hakkas within the Batavia Hua-ch'iao Charity Committee were far from satisfactory. As a result, factional strife broke out and the CantoneseHakkas challenged Fukienese leadership. By the time of the next election of officers, February, 1939, the Cantonese-Hakka group had mustered enough strength to remove Tjong See-gan, a Fukienese, and replace him with Ch'iu Yuan-jung, a Cantonese. ${ }^{102}$ Ch'iu was described by Japanese official sources as "sincere" in business. Although he was known to have spoken against Japan, according to Japanese intelligence, "his real motives [for his anti-Japanese advocacy] were not ascertained." 103 As Willmott aptly points out, there are "linguistic, educational, social, and cultural differences between Totoks [Sinkhehs] and Peranakans [Babas]. As a result, there exist considerable prejudice and social distance between the two speech groups." 104 This observation of the post-war Chinese community in Semarang describes gener- 
ally the social barriers between the two speech groups in the Indies which existed in pre-war years.

Still another weakness in the National Salvation Movement was the lack of dynamic leadership in the Chinese community of the Dutch Indies. There was no Tan Kah Kee, who had enough power and prestige to unite the Malayan Chinese. Consequently, unlike the Chinese in Malaya, the Chinese in the Indies could not organize one central body to coordinate either the boycott campaign or the contribution drive. The Batavia Chinese Charity Committee, the largest organization, was unable to control the general headquarters of similar associations in either the Indies or Java. Tjong See-gan was reportedly unpopular and considered untrustworthy because he was said to have made a fortune during the Manchurian incident boycott, which he strongly advocated, while secretly importing Japanese cotton goods. ${ }^{105}$ It is possible that these rumors had something to do with his removal from his office.

Finally, the KMT did not seem to have the control over the Chinese community leaders that Japanese sources thought they had. No doubt KMT agents were present and did urge the Chinese to boycott Japanese goods, but there was no immediate response; the Chinese community conducted the boycott when it suited their time schedule and economic interests. The Japanese seem to have overestimated the role of the KMT and its control over the anti-Japanese movement, perhaps because they were the victims. The Dutch, too, overreacted, but for different reasons. They wanted to check the politically motivated Chinese anti-Japanese and National Salvation Movement for fear of creating a situation which Japan would seize upon as a pretext to expand her own propaganda machinery. ${ }^{106}$

\section{The Philippines}

A week after the outbreak of the Sino-Japanese incident, the Chinese Chamber of Commerce in Manila sent messages to Chiang Kaishek and General Sung Che-yüan, the commander of the Twenty-ninth Route Army, whose troops were involved in the hostilities, promising that the Chamber of Commerce would support to the hilt the Nationalist government's resolute stand against Japan. ${ }^{107}$ These cablegrams were followed by an invitation to General Ts'ai T'ing-kai, former com- 
mander of the Nineteenth Route Army, to open a fund-raising campaign. The general spoke to various groups, impressing upon the Chinese the importance of monetary aid as a token of their loyal support of Chairman Chiang, ${ }^{108}$ and his speeches engendered a burst of patriotism. Seizing upon that fervor, the Chinese Chamber of Commerce at Manila summoned all business and trade associations to an emergency meeting on July 16. Presiding was Alfonso Sycip Hsueh Fen-shih, president of the Chamber of Commerce, which, along with the KMT group and the consulate general, formed a triumvirate in the Chinese community. ${ }^{109}$ Speaker after speaker pledged unity, and the delegates unanimously resolved to support Chairman Chiang's resistance of the Japanese troops. Finally, they agreed to organize a Philippine Resist-the-Enemy Committee (PREC). ${ }^{110}$ The primary objective of the PREC was to "encourage the Chinese to organize a patriotic movement and to assist the Nationalist government with manpower and materials." On July 19, the day the PREC was formed, it sent letters to Chinese organizations in all parts of the Philippine Islands, urging them to form local resistance committees. They were asked to contribute munitions, to stage a boycott, to organize a Double Seven united giving drive and a monthly contribution campaign for financing the war, and to cut wedding and funeral expenses in order to donate to wounded veterans and war refugees. ${ }^{111}$

Enthusiasm for donations swept the Islands, and money poured in. In late July, wealthy Chinese business leaders in Manila gave 169,000 yuan; and by August 4, donations totaled nearly 260,000 yuan. ${ }^{112}$ By the end of September, a systematic large-scale contribution campaign and a subscription for National Salvation War Bonds were under way throughout the Philippines; ${ }^{113}$ each Chinese family was assigned a contribution quota, and each Chinese wage-earner gave 10 per cent of his monthly income to the war chest. ${ }^{114}$ In contrast, the Chamber of Commerce showed little inclination to boycott although some KMT members, patriots, and radical PREC leaders had asked local resistance committees to stage a boycott. ${ }^{115}$ It appears that only the KMT faction of the PREC wanted one. In early October, Tseng T'ing-chüan (Justo Cabo Chan) ${ }^{116}$ chairman of the KMT Propaganda Department in the Philippines and an executive member of the PREC, demanded a boycott. On the Double Ten anniversary, Chinese Consul General Hsü 
also issued a directive calling for one but failed to evoke enthusiasm among leading moderate merchants of the Chamber of Commerce. ${ }^{117}$ By underscoring the absence of both community solidarity and KMT control, the failure to boycott helps to disprove the opinion that overseas Chinese were cohesive and KMT-controlled, an opinion held by many Japanese who were too quick to see the hand of the KMT. Apparently, the KMT faction was out of step, for Kung Hsiang-hsi, Minister of Finance of the Chinese government, settled the issue, for the time being, in favor of the business circles within the PREC.

In mid-October, Kung visited Manila on his way to the United States. In his speech to the Chinese community, he set forth the objectives of the PREC. In particular, he stressed the vital importance of economic assistance from China's loyal sons and daughters abroad. He brought home the point in the following words: ${ }^{118}$

... Our compatriots overseas are asked to make sacrifices, though they are not fighting the enemy on the battle front. There are many ways to serve the country. As the war protracts, the economic affairs [of the country] are as essential as military matters [for the survival of China]. It is, therefore, absolutely necessary that support for people at home must be provided without cease. The final victory of the war will be with us. The patriotism of the Chinese abroad has been second to none. At this hour of maximum national crisis, I feel it is not necessary to waste time in urging you to respond to the call of your country.

Although Kung did not use the word boycott in his speech, he seemed to suggest that the Filipino-Chinese could demonstrate their patriotism by contributing money instead of resorting to a boycott, which would be ultimately more injurious than beneficial to the Chinese. The Chinese Finance Minister was aware that the moderate course of contribution would be the best way to tap the resources of Filipino-Chinese wealth. As will be shown in Chapter III, the Chinese in the Philippine Islands contributed more per capita to the Chinese treasury, in both money and material, than any other Chinese group in the South Seas region. The theme of the anti-Japanese campaign set by Kung was reiterated by KMT notables who visited the Islands in late October; they solicited contributions and bond subscriptions but did not mention a boycott. ${ }^{120}$

Nevertheless, those Chinese youths, intellectuals, school teachers, and laborers who were dominated by the radical faction-KMT and Communists-advocated the severance of business relations with Japan 
regardless of the consequences. For instance, a large number of Chinese students attended a meeting held on October 31, under the auspices of the League for the Defense of Democracy. The group resolved to denounce the Japanese action in China, to aid China's war effort, to support the position of the Brussels Conference to solve the China question, and to organize a committee for studying effective means of executing a boycott. ${ }^{121}$ A week later, the League met to discuss the possibility of carrying out a boycott organized by longshoremen in order to shut out Japanese goods from the Philippines. In the meantime, Tseng had been travelling throughout the Islands to strengthen anti-Japanese sentiments among his compatriots, and report had it that he had urged leaders of the Sakdalista and the Socialist Pedro Abad Santos to spread anti-Japanese propaganda to the nonChinese elements in the populace. ${ }^{122}$ The youths, intellectuals, teachers, and laborers were eager to support the KMT campaign because of their long standing nationalist views, for which the KMT ideology of the Three Principles might give them some form of nationalist expression.

The business circles, however, remained reluctant to take the plunge into boycotting, despite mounting pressures from the radicals. Representatives of nine guild associations met at the Chinese Chamber of Commerce in Manila on November 24, to discuss the boycott, but they could not agree among themselves. Finally, they voted to postpone the issue until the next general session of the Chamber of Commerce. ${ }^{123}$ Apparently most of the Chamber of Commerce leaders favored postponing the boycott, the position now supported by Consul General Hsü, who had changed his stand to follow the soft line since Kung Hsiang-hsi's visit. Chinese community leadership now split, the Chamber of Commerce group and the Consul General committing themselves to the contribution campaign and the KMT group to boycotting. The business leaders' hesitancy was due, Japanese sources concluded, partly to their bitter experience of business losses during the Tsinan and Manchurian incident boycotts; partly to the need to stock Japanese goods for Christmas, the Chinese New Year, and the Semana Santa, or Holy Week; and partly to apprehensions that a boycott would bring about trade losses, which would impede the campaign for bond subscriptions and contributions. ${ }^{124}$ These assessments were 
supported by statistics, published in 1938 and 1939, that showed a steady increase in Japanese exports to the Philippines between July and December, 1937, and then a sharp decline beginning in January, 1938. They were supported also by the alignment of merchant guild associations, after January or February, 1938, with the boycott faction led by Tseng T'ing-chüan. On the strength of the evidence, one can hardly disagree with Hara Shigeharu, secretary general of the Japanese Chamber of Commerce in Manila, who characterized the period from July to December, 1937, as one of "wait-and-see."125

The next period, January 1 to February 27, 1938, was the time of the "behind-the-scenes maneuvering" of the Resist-the-Enemy committees throughout the Islands. ${ }^{126}$ Meantime, Tseng's drive for a boycott had found a common ground for a meeting of the interests of the KMT and those of the Cotton Cloth Dealers' Association. On January 3, the Association adopted boycott resolutions, and other merchant guild associations soon followed their lead or set up subcommittees to study methods of setting up a boycott. In late January, by which time Chinese merchants had stocked merchandise for the Chinese New Year and Holy Week, eighteen organizations boycotted Japanese goods. ${ }^{127}$ Why did these associations finally decide to observe the KMT-led boycott? In the short run, boycotts would hurt local Chinese businesses that handled Japanese products. But in the long run, Japan was a potential threat to their interests and a Japan-dominated China would be unable-or at least unwilling-to protect their interests. At the same time, Chinese merchants in the Philippine Islands had one advantage that Chinese businessmen in the Indies, for instance, did not have; they could easily find substitutes for Japanese products, particularly cotton piece goods, in the United States, which was sympathetic to China's cause. By purchasing American products the Chinese could kill two birds with one stone. On the one hand, a boycott would hurt Japan directly, as the discussion of trade statistics in Chapter III will show; on the other, it would increase the volume of trade with the United States, whose sympathy for China could scarcely be ignored. Taking the long view, the Chinese merchants decided to boycott Japanese goods, even though business might suffer at the time, hoping that in so doing they could help China, which needed America's aid. To buy American products was to assist China indirectly. 
The Manila government grew increasingly uneasy about the tension that the war and the propaganda of the Resist-the-Enemy Committees had created among the Chinese. Obviously as a measure to cool the rising temper of the Chinese, President Manuel Quezon issued a proclamation on February 3, requesting both Chinese and Japanese residents to exercise restraint. $\mathrm{He}$ asked all Philippine residents, both national and foreign, to "abstain from all public demonstration in favor of or against any of the parties engaged in armed conflict in China" and urged them not to form associations "for the purpose of creating public sentiment in favor of or against any of the contending parties in [the] conflict." ${ }^{28}$ The statement was directed primarily at the Chinese, since it was a shift in their sentiments that had prompted the President's message.

The Chinese boycott leaders paid no attention to Quezon's admonition. In late February, they and the KMT cowed the moderate leaders of the Chamber of Commerce. Tseng T'ing-chüan and Lim Shu-an, a KMT representative from China, taking advantage of the mood of the Chinese merchants, after some intimidation, carried a majority vote in favor of a boycott, to be effective on February $28 .{ }^{129}$ Tseng's KMT faction was now in the ascendancy in the PREC, which had been created within the Chamber of Commerce and guided by business leaders. A week later the Tseng-dominated PREC ratified the Regulations Governing the Execution of Enemy Goods Boycott. The Regulations were as follows:

1. Orders that have been placed and stocked Japanese goods must be registered at the guild association headquarters, to be completed by March 9;

2. The inspection of these orders and goods must be made by guild officials;

3. A deliberate intent to obstruct the boycott drive will be penalized. The penalty includes fines, exposure of the crime to the public, and branding the offender as a traitor;

4. A permit to deal in Japanese goods for which there are no substitutes must be obtained. Stores dealing in non-substitutable Japanese goods are given an extension of three months for clearance;

5. A permit for the movement of non-substitutable Japanese produce and registered stock must be obtained with the payment for the fee;

6. Goods that are produced by the Chinese in the Japanese occupied area of China and by joint Sino-Japanese-Filipino factories in the Islands will be exempted from the boycott;

7. The movement of registered Japanese goods must be reported to the guild association and the Resist-the-Enemy Committee. Their movement without a 
permit will be prohibited, violation of which is subject to the confiscation of the goods as contrabands and fine; and

8. Clandestine dealing in Japanese merchandise through foreign merchants will not be permitted. ${ }^{130}$

Although the Chamber of Commerce circles resigned themselves to the inevitability of the boycott, they were bitter toward the KMT faction, particularly toward Tseng, for the shoddy way the passage of the boycott had been achieved. ${ }^{\mathbf{3 1}}$ Consequently, the business leaders maneuvered to regain control over the PREC and rid themselves of Tseng. What happened less than a month later showed that they had succeeded. In late March, Consul General Hsü was replaced by Yang Kuang-sheng (Kuangson Young), former executive director of the China Press. Upon Yang's arrival in Manila, the consul general announced that the PREC would be under the guidance of the Chamber of Commerce and that Tseng would be removed from the PREC's executive board. ${ }^{132}$ Since the boycott remained intense even after Tseng's removal, it is probable that Tseng was sacrificed for the sake of unity in the Chinese community in Manila. No doubt the central KMT was displeased because Tseng's handling of the boycott issue had alienated the influential businessmen. His dismissal was a way of placating them. The success of the Chamber of Commerce was an indication that the KMT was not in the saddle.

Having resolved their differences, the Chinese community leaders and the KMT government set out to intensify the boycott. It was beginning to hurt Japanese business in the Islands, particularly the large importing firms whose business volume was reduced in April, May, and June. The Japanese position became even more tenuous when Japan restricted foreign exchange and shifted to a war economy. As a result, Japanese cloth, foods, and metalware were not only scarce but also too expensive to compete with American products. ${ }^{133}$ The Chinese victory at Taierchwang in April and the Japanese capture of Amoy, the home of most of the Filipino-Chinese, and Hsüchow in May helped stir up the national spirit of the Chinese. Already, representatives of twenty-two organizations in Manila had pledged to support whatever boycott resolutions the PREC would pass and had vowed to discipline their uncooperative members. ${ }^{134}$ After the Japanese occupation of Amoy, which coincided with the expiration of a three- 
month grace period for disposing of products available only from Japan, the boycott was tightened to plug loopholes through which some Chinese had secretly been conducting business with the Japanese. ${ }^{135}$ Some Chinese and Taiwanese employed by Japanese firms were intimidated. ${ }^{136}$

Since early spring there had been a steady rise in the number of gloomy letters from local Japanese officials and businessmen to the Foreign Office in Tokyo. The Japanese Association in Capiz, Panay, predicted that the Japanese shops in that city would be forced to close should the boycott be continued. ${ }^{137}$ The official journal of the Japan Bicycle Exporters' Association, Yushitsu Jitensha, was even more pessimistic: "The prospect for the import of merchandise from Japan remains very dim as long as the Sino-Japanese war continues." ${ }^{\text {"138 }}$ Japanese importers were helpless and could do nothing but wait, hoping that eventually the boycott would be less strictly enforced. ${ }^{139}$ To observe the first anniversary of the Sino-Japanese war, the consul general, the Chinese Chamber of Commerce, and the PREC sponsored a rally in Manila. The Chinese at the assembly hall renewed their pledges to carry out the boycott and promised to donate more money to the Chiang Kai-shek government. ${ }^{140}$

The Resist-the-Enemy Committees, which had been active throughout the Islands since August, 1937, were extremely successful in collecting contributions for relief, medicines, airplanes, and munitions and in getting subscriptions for bonds. The results were excellent. Japanese official sources reported that Chinese everywhere were eager to contribute, and that money was flowing into the treasury of local committees. Even in a small town in Leyte, where there were only forty Chinese, the committee collected nearly six thousand dollars between July 7, 1937, and July 7, 1939. The propaganda, boycott, and contribution campaigns conducted by the 2,000 Chinese in Davao, a Japanese economic stronghold with a population of over 20,000, were reported to be among the most intense in the Islands. In the two years after the outbreak of war, they gave more than a million yuan.

Summarizing the spirit of sacrifice for the National Salvation Movement, the Japanese Foreign Office said: "Never before has the patriotic passion of the Chinese been so high." In Manila, though, enthusiasm for relief work and contributions began to wane in August, 
1938, when Dee C. Chuan, the most powerful Chinese businessman in the city, went to the United States for medical treatment, leaving the Manila Chinese organization temporarily without a leader. "Chinese in local provinces," said a student of the overseas Chinese, "are not only giving more than the Chinese in Manila in proportion to their assets and income, but also their local contribution network is reaching more thoroughly than in Manila. The tight-knit organization, the seriousness of administering discipline, and the record of giving are far superior to those in Manila."141

The spirit of sacrifice was best seen in the enthusiastic response to the slogan "Save China by Airplanes." In March, shortly after the systematic boycott was declared, the Filipino-Chinese organized a branch of the China Association for the Construction of Airplanes at the request of its headquarters in China. The movement intensified Chinese patriotism. By the end of 1939, thirty-three branches had been organized throughout the Islands. The Chinese in Manila alone gave the Association money for ten airplanes, and by July 7, 1939, the Chinese in the provinces had donated enough for twenty-six. ${ }^{142}$ The Chinese women did not lag in giving their time, energy, and talents to aid China. They formed the Chinese Women's Association for the Comfort of Self-Defending Soldiers. Executive members of the Association were wives of prominent leaders of the Chinese community, and its branches mushroomed in local districts to raise money for ambulances, drugs, winter clothing, gas masks, first aid kits, vaccines, and airplanes, and to collect old clothing, transport wagons, and hop sacks. During 1937 and 1938, the Women's Associations raised nearly 400,000 yuan. ${ }^{143}$ The desire to participate in the National Salvation Movement spread to Chinese school boys and girls. Instead of contributing cash, they voluntarily gave up such "luxuries" as dancing and permanent waves, and fined offenders. Even habitual Chinese gamblers and opium smokers were not left out of the National Salvation Movement. Pricked by a local newspaper article reporting that Chinese were smoking opium smuggled from Japan, the Consul General begged Chinese residents to "stop smoking opium and devote themselves to the cause of the National Salvation Movement." 144

The most outstanding feature of the Chinese anti-Japanese activities in the Philippine Islands was the absence of violence. Credit for this 
should be given to level-headed Chinese leaders who saw the advantages of moderation for protecting the interest of Chinese residents and for winning the sympathy of China's friends in the Islands. ${ }^{145}$ The second reason for the success of the campaign was the legal existence of the KMT. The Party operated with relative freedom from the restriction which handicapped it in the Netherlands Indies, Thailand, and British Malaya. This does not mean that KMT activities were unrestrained. The Philippine authorities, like the authorities in Malaya, were suspicious of the political overtones of the Chinese National Salvation Movement. The presidential proclamation in February, 1938, showed that the Philippine government did not view kindly the Chinese anti-Japanese activities. In fact, judging from the close relations maintained with Filipino officials, including President Quezon, by the Japanese, the latter seemed to have won the sympathy of the Philippine oligarchy, with whom they had cultivated their ties since $1935 .{ }^{146}$ Moreover, the Chinese had to cope with the rising tide of Filipino national consciousness. Since the 1920's Filipino nationalists had been attempting to curb Chinese economic power. ${ }^{147}$ The Chinese nationalist movement, of which the anti-Japanese campaign was part, would bring to the surface the latent anti-Chinese feelings of the Filipinos. ${ }^{148}$ Undoubtedly, the leaders of the Chinese community carefully considered this possibility before deciding to impose the boycott, and it must have haunted them during the months the boycott was in effect.

\section{Thailand}

Of all the Nanyang Chinese National Salvation Movements, Thailand's is the most interesting to students because Thailand was the only independent nation in Southeast Asia and Japan's influence was in the ascendency in the late 1930's. As Professor G. William Skinner observed, to understand the Thai government's policy towards the Chinese, one must consider its position in international politics. Skinner said: "As anti-Japanese activities came in the thirties to dominate Chinese politics in Siam, Japanese power was in rapid ascendancy, and the Thai-whether admiration for the Japanese example played a part or not-had to be especially careful not to offend Dai Nippon."149 The Thai government, therefore, was cautious in her relations with Japan when the Sino-Japanese conflict occurred. As early as December 
30, 1937, Luang Pradjist Manudbam, Foreign Minister, declared that his government intended to maintain "a strict neutral policy toward the Sino-Japanese conflict; it is neither pro-Japanese nor anti-Japanese." ${ }^{150}$ On the other hand, since 1932, the government's policy toward Chinese residents had been discriminatory and nationalistic. Yet its relations with the Chinese government on the eve of the Sino-Japanese war were said to be "... a their most nearly cordial since the mid twenties," relations; and the Thai government seemingly tolerated the existence of the KMT, though it had been declared illegal.

In keeping with its stated policy of neutrality, the Bangkok government declined a local Chinese newspaper owner's offer to provide the Thai press with translated Chinese news from the China Central News Agency because such an arrangement might "infringe upon Thailand's international relations." 152 Three times in July, 1937, the government served notices to all publishers and editors, forbidding them to print anything but straight news. They were told to exclude comments that could be construed as derogatory to Japan. Despite this warning, a number of Chinese and Thai newspapers financed by Chinese printed sensational and inflammatory articles about the war and agitated for political action. The government's response was stern; in August it suspended publication of two Chinese-operated newspapers for having printed anti-Japanese news and in the next two months closed or fined eleven dailies for similar reasons. ${ }^{153}$

On the other hand, there was no threat of a boycott in the first few months. In August, Minister Murai informed the Tokyo government that cotton piece goods were being boycotted, but the tone of his cables was in no way alarming. ${ }^{154}$ Only with the spread of the war to central and southern China in September, did the Chinese agitate for a boycott. They were incited by tragic tales spread by newly arrived refugees from China. A systematic boycott began the first week of October, although there was no formal declaration by the Bangkok Chinese Chamber of Commerce. Why did the Chamber of Commerce, which directed the boycott, procrastinate until October? Its failure to impose a boycott until it had received numerous orders from the Overseas Chinese Affairs Commission and the China Federation of Chambers of Commerce suggests disagreement among the leaders. 
It seems that some of them were afraid of what the Thai government would do when the Chamber of Commerce openly endorsed the boycott, an act which would incur the government's hostility. On the other hand, the Chamber of Commerce had been under strong pressure to boycott. Caught in this uncomfortable situation, it seems, the Chamber of Commerce acquiesced to the boycott but made no public declaration. Instead, it made the boycott appear to be a voluntary movement while supporting it behind the scenes. Once the boycott was underway, however, the KMT faction exerted more pressure on the Chamber of Commerce.

Soon the Japanese felt the initial impact of the boycott. Chinese merchants cancelled contracts with Japanese firms. Japanese importers had to rely upon Indians and Thais to distribute and retail cotton piece goods. ${ }^{155}$ Chinese coolies refused to unload cargo from Japanese ships, and hot-tempered Chinese assaulted a Mitsui employee. Eight such assaults, in one of which a person was killed, were reported in October. ${ }^{156}$ The boycott disrupted the shipping of Siamese rice to Japan, although its shipping to Cuba reportedly remained normal. The Mitsui Lines, a leading Japanese trading firm doing business in Thailand, conceded that by the end of October the company had lost one-third of the revenue from shipping exports and was having difficulty getting cargoes from Thailand to Japan. An official of the Mitsui ascribed the business losses to a walkout staged by Chinese longshoremen, the intensified boycott, and accelerated terrorism. ${ }^{\mathbf{1 5 7}}$

The outbreak of terrorism, extortion, and highjacking in October prompted the Japanese Minister to call upon the Bangkok Police Headquarters to protect the lives and property of Japanese and of those working for them. ${ }^{158}$ Acting upon the Japanese request, the Thai police, in the first of a series of police raids, arrested nineteen Chinese on October $27 .^{159}$ The arrest, however, did not discourage terrorism; more intimidations and attacks followed in November. Members of underground strong-arm organizations threatened or actually assaulted not only Chinese and Japanese but also Indian shop owners in an effort to frighten them into boycotting Japanese merchandise. ${ }^{\mathbf{1 6 0}}$ Shortly after the fall of Nanking, KMT agents arrived from Singapore, reportedly to cooperate with the Chinese secret societies in organizing a boycott inspection corps. ${ }^{161}$ The presence of the KMT 
agents provocateurs of terrorism was evident in the fresh outbreak of assaults and arson. A Chinese teak merchant serving as an agent for the Mitsui was attacked by terrorists and lost his arm; a Mitsui truck laden with raw hides was highjacked; a Mitsui warehouse was set ablaze; and wealthy Chinese merchants were compelled to increase their contributions. ${ }^{162}$ The Thai police reacted swiftly. Policemen raided Chinese associations known to harbor undesirables and arrested a score of suspects, in addition to eight bond subscription promoters sent by the KMT government. ${ }^{163}$ Several of the arrested leaders were later expelled from the Kingdom, and eighteen secret societies were disbanded. ${ }^{164}$ The illegal activities were attributed to the Hua-ch'iao Resist-the-Enemy Association for National Salvation, known as Hua$k$ 'ang, and the organization "was closely connected with several of the most reputable Chinese community leaders and under the direct control of the Chinese Chamber of Commerce." 165

The Thai police action temporarily subdued the Chinese boycott movement, but in April the Chinese resumed an active boycott drive. On April 1, Chinese in Chiengmai, the second largest city in Thailand, joined their compatriots in the boycott campaign. In late May, Chinese assailants murdered a Formosan-Japanese because his firm had bought tea from the Mitsui Trading Company; this was the first murder of a Japanese citizen. The assassination shocked Japanese residents, making them realize the gravity of the anti-Japanese movement. In June and July, high Chinese officials visited Thailand ostensibly to strengthen Chinese national spirit as the Japanese troops advanced to southern China. Everywhere they went, the visitors preached the need for money for a protracted war, asking their compatriots to put their faith in the ultimate victory of the Chinese. The Japanese bombings of Swatow and Hainan Island intensified the boycott; Chinese newspapers again published anti-Japanese editorials, and terrorist activities resumed. ${ }^{166}$

The Chinese National Salvation Movement and its persistent illicit activities did not endear the Chinese to the Thais. As early as October and November, 1937, when the Chinese intensified the anti-Japanese drive, angry letters flooded the desks of the editors of the Bangkok Times and the Siam Chronicle, decrying the behavior of the Chinese and demanding that the police show more resolution in curbing their 
lawlessness. ${ }^{167}$ It is significant to note that Thai public opinion toward the Chinese was shifting to the right of center. Before 1938, relations between the mass of the Thais and the Chinese were less hostile than those between the Thai elite and the Chinese. ${ }^{168}$ Now the angry and unhappy masses who were certainly inconvenienced by the boycott, added fuel to the anti-Sinicism. An ominous sign of Thai nationalism emerged. In 1938, the sentiments that in 1939 would crystallize into an intense campaign against the Chinese were expressed in a newspaper editorial and in the words of a high government official. On March 1, a local Thai daily vented the exasperation of the public, calling the Chinese the Jews of the Orient; ${ }^{169}$ and on July 15 , Luang Wijit Wathakan, a cabinet minister and director of the Fine Arts Department, denounced the Chinese habit of remitting money to their homeland and compared the Chinese problem in Thailand to the Jewish problem in Nazi Germany. ${ }^{170}$

The Wathakan episode took the force out of the Chinese anti-Japanese campaign temporarily, but terrorism soon resumed. Rumors of the massacre of Japanese were widespread in mid-August, alerting the Bangkok police and frightening everyone who dealt in Japanese merchandise. Anti-Japanese activists were determined to weaken Japan's position in Thailand. As Ōtani Chōzō, the owner of the Ōtani Trading Company in Bangkok, said, one of the characteristics of the anti-Japanese drive was "terrorism executed by agents sent by the KMT government for the sole purpose of murdering in cold blood any Chinese who would handle Japanese goods." ${ }^{171}$ Nowhere else were there so many assaults and assassinations as in Thailand, where by July, 1938, terrorists had killed at least six merchants who had sold Japanese products. The indignant Thai authorities were resolved to clean out the undesirables. On March 8, Thai police arrested twenty-four Chinese, three of whom were indicted; in June, a Thai court sentenced to life imprisonment the assassins of the aforementioned Taiwanese of Japanese citizenship, and the police apprehended three more of his assailants; on July 7, the first anniversary of the Sino-Japanese war, the police arrested nine terrorists in a raid of their headquarters and detained more than a dozen Chinese who were distributing anti-Japanese leaflets; on August 3, police captured six extortionists who were attacking two Chinese merchants; and finally, in September, the police 
ferreted out 5,808 Chinese opium addicts and arrested them for violation of the 1937 Alien Registration Act. ${ }^{172}$ Many of those addicts arrested were suspected of having engaged in anti-Japanese activities. Despite the police roundups, the boycott continued, but with diminishing enthusiasm.

The Chinese not only conducted the underground boycott and the anti-Japanese campaign approved by the Chamber of Commerce but, with the cooperation of the KMT Government Office of Commercial Representative and the Thailand Office of the KMT, organized the illegal Thai-Chinese Relief Fund-Raising Association. Ch'en Shouming, ${ }^{173}$ the Commercial Representative, became the chairman of the Relief Association, assisted by eleven committee members; most of them were officers of the Chinese chambers of commerce. The Relief Association was divided into twenty-eight branch offices scattered throughout Thailand, each organized according to guilds and speech groups. The structure was similar to that of branches in Malaya, the Indies, and the Philippines. Under the authority of the Relief Association, such cultural associations as T'ung-hsi she and Li-chih she and Chinese schools raised money. To implement the Relief Association's fund-raising drive, the Thailand Office of the KMT created the Hua-k'ang within the San-min she, a youth club which was formed for the dissemination of San-Min-Chu-I. The Hua-k'ang local offices were established throughout Thailand. The Relief Association branches shared office space with the Hua-k'ang's local offices. The illegal Hua-k'ang employed a number of strong-arm men for extortion, intimidation, and terrorism to enforce the boycott, and it was active in checking the influence of the Communist Party. ${ }^{174}$

Response to the contribution campaign was said to be excellent in the early months of the war, but it declined because the Teochius and the Hainanese (the Ch'iungchou group) disagreed over the distribution of the money. The deteriorating war situation magnified their differences. The Ch'iungchou group was reportedly reluctant to put its stake on the Chiang Kai-shek regime and by March, 1938, had withdrawn its support from the KMT government. Even within the Teochiu community, signs of vacillation were detectable. So serious had the situation become that the KMT government and the military are said to have secretly dispatched their high ranking officials to mend 
fences. ${ }^{175}$ If this information is true, we find some evidence to support the argument that the Hainanese were oriented to the Left. As the poorest speech group, the Hainanese were more disposed to extremism and more active in leftist organizations than the other groups. The Hainanese did not want the KMT government to get all the money; they wanted the Chinese Communists to get an equal share. They might also have demanded that it be sent directly to a Communist agency, not channelled through the Chungking government. The Communists appeared to have won over the Hainanese in Thailand. In no other country was a speech group alienated from the KMT government.

Notwithstanding these difficulties, the money raising went on as an underground operation. Probably no one knew how much the Chinese collected because of the clandestine nature of the campaign and because of repeated police raids. Two figures available from Chinese sources give some inkling of the achievement of the fund-raising for national defense. The China Federation of Chambers of Commerce disclosed that the Chinese in Thailand donated 705,086 bahts between August, 1937, and February, 1938. In October, 1938, the Nanyang Chinese Relief General Association reported that the ThaiChinese had contributed eight million yuan to China between July, 1937, and October, $1938 .{ }^{176}$ There is no way of ascertaining whether the eight million yuan includes the 705,086 bahts. Eight million yuan is by no means large in comparison with the sums donated by Chinese in other countries.

In summary, physical violence and coercion marked the ThaiChinese National Salvation Movement in contrast to movements in Malaya, the Indies, and the Philippines. Why did the Chinese defy the authority of the host government, risking their lives and the good names of their organizations as well as that of their community? The first reason may be Thailand's propinquity to China in the north and contiguity with Malaya in the south. A good number of KMT and Communist agents were known to have entered the Kingdom from both directions in order to set anti-Japanese activities in motion. ${ }^{177}$ Why were so many agitators necessary in Thailand? We can assume that high authorities were dissatisfied with the community leaders' organization and management of the Thai-Chinese anti-Japanese 
movement. The Chamber of Commerce's initial reluctance to boycott and the numerous intimidations support that view. Leaders of the Chamber of Commerce were, for good reasons, apprehensive of the economic and political consequences of the boycott, for Thailand was a free market for Japanese merchandise, which provided more than half of the Kingdom's consumer goods market. Because Japanese firms extended convenient credit terms, the Chinese merchants, who had limited capital, could not afford a long boycott. The memory of the economic setback caused by the Manchurian incident boycott strengthened their reluctance. Boycotting Japanese products would certainly engender ill will in the Thais, especially the anti-Chinese Thai elite. The Chinese leaders did not wish to antagonize the Thai elite; they wanted to maintain the status quo as long as possible. That attitude explains why, despite KMT pressure, the support of the boycott was less than whole-hearted at the Chinese Chamber of Commerce meeting in December, 1938. It was disclosed that many influential merchants complained that the boycott was bankrupting them and helping Indian merchants at their expense. ${ }^{178}$ Their lukewarm attitude may have been a reason for the lax boycott enforcement and the resultant back door deals and intimidations.

A study of the Thai-Chinese National Salvation Movement may raise questions about KMT control over the Chinese Chamber of Commerce. It must be pointed out that relations of the Thai-Chinese Chamber of Commerce with both the KMT and the Chinese government were unique; the KMT was not a legal party in Thailand nor did the Chinese government have formal diplomatic relations with the Kingdom. The Chamber of Commerce, in the absence of the official representatives of the party and the government, presumably represented their interests. In that capacity, the authority of the Chamber of Commerce was equal to, if not stronger than, the authority of both the KMT and the Chinese government. Therefore, KMT and government agents in Thailand had, it seems, a unique control problem. The KMT could not completely dominate the Chamber of Commerce, and the Chinese community leaders did not automatically accept KMT directives. In Thailand, economic interests were put ahead of party control. Another interesting facet of the National Salvation Movement deserves mention-the role of Hsiao Fo-ch'eng, 
the long undisputed leader of the Chinese community. He served on the committee of the Thai-Chinese Relief Fund-Raising Association, but curiously he did not associate himself with the Hua-k'ang, an exclusive KMT organization, although he was an illustrious KMT member of long standing. It is not clear why he was not active in the Huak'ang; he had been active in anti-Japanese movements after the Tsinan and Manchurian incidents. Perhaps his membership in the Southwestern faction, a KMT political clique opposed to Chiang Kai-shek's leadership, made him drift away from Chiang. Consequently, as a Japanese source has suggested, the Chinese Chamber of Commerce, which he dominated until 1938, was not eager to launch the boycott movement. ${ }^{179}$ That may or may not be true, but it is true that when he died in June, 1939, the Chinese community lost a strong and stable leader. His death weakened the leadership of the Chamber of Commerce, perhaps even its disciplinary power over members.

Finally, the Thai-Chinese National Salvation Movement, like its sister organizations in Malaya, the Indies, and the Philippines, was plagued by factionalism - the disagreement between the Teochius and the Hainanese-which sapped its strength and weakened its unity.

To balance the picture, I wish to stress the fact that the anti-Japanese movement in Thailand continued for months and even years under the most adverse conditions. For reasons stated in this study, the nationalistic Thai government's policy in dealing with the Chinese was one of systematic persecution, a far cry from its professed neutrality. It was, if anything, a neutral policy slanted in favor of Japan. This fact is significant in evaluating the achievement of the Chinese National Salvation Movement in Thailand.

\section{French Indochina and Burma}

In French Indochina, particularly in the Saigon-Cholon area, Haiphong, and Hanoi, there were no overt anti-Japanese and boycott activities in July and August, although agents of the Chiang Kai-shek government had been reported active behind the scenes. Meanwhile, fund-raising organizations for war refugees and China's war chest had been formed in Tonkin, Annam, Cambodia, and Cochin China. The most important association in directing the National Salvation Movement was the General Association for Vietnam and Southern District 
Chinese National Salvation at Saigon, where 200,000 Chinese had congregated. It was organized in August, 1937, to promote the sale of war bonds and government bonds, to campaign for monthly contributions, to carry out a drive to eradicate "inferior goods," to train cadres for the National Salvation Movement, and to send trained personnel to China for development projects and comfort missions. ${ }^{180}$ The KMT Haiphong and Annam Offices were responsible for directing these activities. ${ }^{181}$

By all indications, the boycott began in late August. Already the transport of Japanese goods from Saigon to Cambodia had been cut off because a Mekong River Transport Company owned by a Chinese refused to take Japanese cargo. The sale of Japanese-made "ice cake" dropped sharply as a result of a Chinese newspaper's allegation that it contained poison. A Chinese in Saigon whom boycott inspectors caught in the act of dealing with a Japanese firm was threatened with deportation unless he paid a heavy fine. In the north, Chinese in Hanoi and Haiphong, together with refugees from China, organized a boycott in October. ${ }^{182}$

The Chinese in Indochina used various methods to collect money for the KMT government. According to a report submitted to the Nanyang Hua-ch'iao Relief General Association, they raised 4.4 million yuan in the first year of the war. ${ }^{183}$ Per capita, they contributed more than the Thai-Chinese, although the total contribution was much smaller. Haiphong Chinese promised to reduce food expenses by one piaster a day in order to donate airplanes to the KMT government. Through this campaign they collected as much as seven thousand piasters a month. In late 1938, the Chinese in Hanoi matched their subscription of war bonds to the amount of the income tax they paid. $^{184}$

A contrast to the hostility under which the Thai-Chinese had to conduct their anti-Japanese activities was the permissiveness of the French in Indochina. Japanese observers outspokenly criticized the pro-Kuomintang attitude of the French authorities. They attributed the effectiveness of the Chinese boycott and the plight of the Japanese in part to French toleration. ${ }^{185}$

In Burma, Chinese in Rangoon organized a national salvation association on July 20, 1937. The organization adopted resolutions essen- 
tially identical to those passed by the French-Chinese national salvation association. ${ }^{186}$ In response to the association's slogan, "Give your money and give your strength," Chinese devoted themselves to a contribution drive for the KMT government's treasury. The result was splendid; they collected 3.4 million yuan in the first year of the war. ${ }^{187}$

The initial campaign to boycott Japanese goods and to generate patriotism was less vigorous than the fund-raising drive. Some Chinese had formed the Iron Blood Corps and the Tiger Association to enforce the boycott upon Chinese merchants and to intimidate Japanese and Taiwanese residents. Chinese newspapers, intellectuals, and KMT members provided the leadership, and they even tried to mobilize the sympathy of an element of the Indian Congress Party. Meanwhile, for Chinese readers, the Kak Min Jit Poh, a KMT daily, printed news distributed by the Chinese Central News Agency. ${ }^{188}$ In the long run, however, the Chinese failed to diminish substantially Japan's cotton exports to Burma, ${ }^{189}$ and their anti-Japanese activities were moderate throughout the rest of 1937 and 1938, except in October, 1938, when the boycott fervor rekindled in conjunction with the fall of Canton and visits of high-ranking KMT officials. ${ }^{190}$

The inefficacy of the boycott could be ascribed largely to the balance of economic strength between the Chinese and the Indians in Burma. Chinese dominated economic life in the other Southeast Asian countries but not in Burma. The Indians, who outnumbered the Chinese, dominated the Burmese economy. Japanese articles were readily available from Indian shopkeepers and importers who dealt directly with Japanese firms.

I have examined the Nanyang Chinese National Salvation Movement, country by country, in some detail to demonstrate the extent and magnitude of Chinese response to the Sino-Japanese hostilities. The response varied according to local conditions, but among Nanyang Hua-ch'iao everywhere there was a surge of national spirit in support of the Chiang Kai-shek government. They used every conceivable means to mobilize every ounce of their strength and every penny of their resources. It is true that motives were not always patriotic and that some Chinese did not cooperate, but most of them were eager to help the KMT government. It is true that factionalism, rivalry, and disagreement existed, but the anti-Japanese movement was generally 
well-organized and united. Thanks to the cooperation of local Chinese associations, notably Chinese Chambers of Commerce, the influence of the KMT increased in Chinese communities. Through these organizations, the KMT organized a rather effective national salvation movement. The KMT did not have exclusive control of the movement, however. Under the cover of the united front, Communists infiltrated the National Salvation Movement, and their increasing influence alarmed local governments.

Until October, 1938, there was no attempt to unite the national salvation associations of Southeast Asia under centralized command. However, once this unified headquarters was created on the Double Ten anniversary in 1938, the Nanyang Chinese National Salvation Movement became an even more formidable weapon for China and a menace to Japan. In the next chapter, I shall examine the second phase of the National Salvation Movement. 


\section{Chapter II}

\section{The Nanyang Chinese and the Anti- Japanese National Salvation Movement, Second Phase (October, 1938- December, 1941)}

The Sino-Japanese war patently excited the passion of the Nanyang Chinese for their ancestral land, and China's tenacious resistance induced them to sacrifice for the cause of China. Their contributions, bond subscriptions, and other forms of raising funds showed the degree of their response to the war.

The Nanyang Chinese, however, had no central headquarters to coordinate their activities and to accelerate their aid program. Dee C. Chuan, a Manila Fukienese who understood the importance of centralization after the fall of Amoy in May, 1938, appealed to leaders of Fukienese associations in Southeast Asia to call Fukien Chinese to a meeting in Hong Kong. ${ }^{1}$ Dee's proposal immediately gained the support of leaders of Fukienese associations in other countries, who recommended that the meeting not be confined to Fukienese. Tjong See-gan of Batavia proposed Singapore as the meeting place and suggested that all Chinese speech groups be invited. Having secured Dee's approval, Tjong communicated with Kung Hsiang-hsi, the Vice President of the Executive Yüan and the Finance Minister of the KMT government, explaining the objectives of the meeting and requesting the guidance and direction of the KMT government. Kung, in turn, sent a cable to Tan Kah Kee, a Fukienese prominent in the Singapore Chinese community, informing him of his correspondence with Tjong. Kung's purpose, apparently, was to secure Tan's approval of the meeting. It is interesting that Dee and Tjong had to employ Kung's prestige to persuade Tan, a fellow Fukienese. Available sources provide no explanation for their indirect approach, but Tan's autobiography implies that at first he was not enthusiastic about the project. He hedged about committing himself to it on the grounds that "complex circumstances existing in Malaya" would make it difficult to hold such a meeting in Singapore. It appears that Tan was apprehensive of the increasing in- 
fluence of the Kuomintang in the National Salvation Movement and felt that without its interference he would "be in a better position to bring in larger donations towards the China Relief Fund." Tan was, however, pressed by Consul General Kao, who, acting upon Kung's instructions, coaxed the patriarch of the Singapore Chinese community to support the meeting. Kung and Tan reached an understanding in late August. Meanwhile, Kung asked consuls to relay to leaders of Nanyang Chinese communities his requests to send representatives to the assembly on October 10 .

It should be noted that it took less than five months to organize this "unprecedented" meeting-an indication of the Nanyang Huach'iao's enthusiasm for the cause of their fatherland. The Nanyang Chinese National Salvation Movement made a landmark when, on October 10, 160 delegates from 45 cities in Malaya, the Netherlands Indies, the Philippines, Thailand, French Indochina, Burma, Sarawak, North Borneo, and Hong Kong gathered at the Hua-ch'iao Middle School in Singapore. ${ }^{3}$ The convention lasted for six days, but the delegates "remained jubilant with no sign of fatigue." ${ }^{4}$ The session discussed and adopted resolutions that the Nanyang Chinese would promote the contribution drive; collect funds for the relief of war refugees in Fukien and Kwangtung provinces; expand the market for China's produce; educate people by means of mass media; execute a campaign for savings and frugality; donate medical equipment and drugs; and promote a drive to encourage Chinese to return to China for either military or nonmilitary service. ${ }^{5}$. Their maxims were, the resolutions declared, "Give our wealth for the defense of the fatherland," and "Save money to strengthen China's fighting capabilities." Neither before nor since in the history of Nanyang Chinese nationalism has there been such strong support for China. Nanyang Chinese concern for China's survival transcended old loyalties to family, clan, ancestral province, and guild associations, uniting six and a half million Chinese in support of the Chinese government. This sense of unity and allegiance was embodied in a declaration adopted at the meeting:

We resolve to aid China's war for self-defense, for the vindication of the principles of the League of Nations, and for the peace of the world. Chairman Chiang Kai-shek is the only leader whom 470 million Chinese at home and abroad sup- 
port. ... His determination [to resist the Japanese] is the expression of the Chinese people's will to fight. Therefore, we urge Chairman Chiang to fight to the end of the war.

The delegates expressed their abiding confidence in victory, pledging to help China "cleanse herself from one hundred years of humiliation with blood and sweat," to buy more government bonds, to buy only Chinese products in order to promote China's industries, and to organize enterprises for the development of natural resources. ${ }^{7}$

The assembly elected Tan Kah Kee chairman of the Nanyang Chinese Relief General Association (NCRGA) and Dee C. Chuan and Tjong See-gan vice-chairmen. ${ }^{8}$ Table 1 is a list of the officers.

\section{TABLE 1}

A List of Officers of the NCRGA

$\begin{array}{llll}\text { Chairman } & \text { Tan Kah Kee* } & \text { Fukienese } & \text { Malaya } \\ \text { Vice-chairmen } & \text { Dee C. Chuan* } & \text { Fukienese } & \text { Philippines } \\ & \text { Tjong See-gan* } & \text { Fukienese } & \text { Netherlands Indies } \\ \text { Treasurer } & \text { Lum Mun Tin* } & \text { Cantonese } & \text { Malaya } \\ \text { Secretary } & \text { Ching Kee Sun* } & \text { Cantonese } & \text { Malaya } \\ \text { Members of } & \text { Ho Pao-jen } & \text { Fukienese } & \text { Malaya } \\ \text { the Executive } & \text { Tan Chin Hean* } & \text { Teochius } & \text { Malaya } \\ \text { Committee } & \text { Ong Chuan-sien* } & \text { Fukienese } & \text { Philippines } \\ & \text { Tan Ean Kiam* } & \text { Fukienese } & \text { Malaya } \\ & \text { Tan Samto } & \text { Fukienese } & \text { Philippines } \\ & \text { Lee Chim Tian* } & \text { Fukienese } & \text { Malaya } \\ & \text { Kow Say Huan* } & \text { Fukienese } & \text { Malaya } \\ & \text { Ch'en Chao-chi } & \text { Fukienese } & \text { Indochina } \\ & \text { Ch'en Chan-mei } & \text { Fukienese } & \text { Malaya } \\ & \text { Huang Chung-chi } & \text { Fukienese } & \text { Malaya } \\ & \text { Chow Hean Swee* } & \text { Fukienese } & \text { Malaya } \\ & \text { Liu Yü-shui } & \text { Fukienese } & \text { Malaya } \\ & \text { Lee Kong Chian* } & \text { Fukienese } & \text { Malaya } \\ & \text { Li Hsiao-wu } & \text { Fukienese } & \text { Malaya } \\ & \text { Huang Yi-t'ang } & \text { Fukienese } & \text { Malaya } \\ & \text { Liang Jui-nan } & & \text { Malaya }\end{array}$

(The asterisks identify leaders in the anti-Japanese movement.)

The list of officers shows that the NCRGA was predominantly a MalayFukienese association. It is significant too that Aw Boon Haw (Hakka) of Singapore, Ch'iu Yuan-jung (Cantonese) of Batavia, and Hung 
Yüan-yüan (local-born Fukienese) of Batavia were not executives. Why they were excluded is not known. What is known is that Japanese intelligence described Aw Boon Haw as pro-Japanese and Ch'iu Yuan-jung as politically non-committed. ${ }^{9}$ The same source reported that Hung Yüan-yüan was very active in anti-Japanese activity. As the publisher of the Chinese-Malayan newspaper Sin Po, he was a leading intellectual in Java and was a KMT ideologist. Moreover, he was a translator for the KMT government's Batavia Consul General. ${ }^{10}$ His background strongly suggests a committed KMT member and a proponent of its ideology. Perhaps for those reasons he was not named to the executive board. It is interesting that there was only one KMT member, Ong Chuan-sien, on the executive board. One may conjecture that Tan Kah Kee and his colleagues wanted to support China but did not want KMT interference. Also in the realm of speculation is the way that Tan Kah Kee was able to pack the Executive Committee with so many Fukienese. In view of his independent attitude toward the KMT, it is possible that he wanted to counterbalance Cantonese influence in the KMT and KMT influence in the National Salvation Movement. Whatever the consequence of this factionalism, that such a diversified group met at all under one roof for the cause of China was significant to the KMT government, as evidenced by Consul General Kao's presence throughout the session. ${ }^{11}$ Finally, none of the Singapore-born elite Chinese was added to the executive board. Conspicuously absent, though, were such leading Singapore Chinese as Lim Boon Keng, Song Ong Siang, Wee Swee Teow, Chan Sze Jin, and Lim Han Hoe, who were identified as British-oriented. The fact that local-born Chinese leaders in Malaya, the Netherlands Indies (Hung Yüan-yüan), and the Philippines were excluded from the ruling circle of the NCRGA indicated that it was controlled by a group of Chinaborn and China-oriented leaders. This exclusion of local-born and Western-oriented leaders seems to point out a division between the two groups. Furthermore, the Nanyang Chinese National Salvation Movement appeared to be promoted by the China-oriented Chinese.

A test of Nanyang Hua-ch'iao allegiance to the KMT government came when Wang Ching-wei defected from Chungking in December, 1938, and, under the tutelage of the Japanese government, tried to woo the Nanyang Hua-ch'iao away from the Chiang Kai-shek govern- 
ment. ${ }^{12}$ Shortly after the capitulation of Canton and Wuhan in October, 1938, Reuters dispatched an unconfirmed report that Wang, vicechairman of the KMT Central Political Committee, was desirous of a settlement of hostilities. The news drew a lightning response from the NCRGA. On October 22, Tan Kah Kee, in the name of the NCRGA, demanded that Wang Ching-wei explain and urged him to "maintain a firm attitude and devotion to the cause of national salvation and the war of resistance." "The overseas Chinese," Tan declared, "will not subscribe to or support any peace movement." On the same day, the chairman of the NCRGA sent a cablegram to Kung Hsiang-hsi, asking him to verify the Reuters dispatch and to investigate a rumor that Chiang Kai-shek was considering resigning his post. He also exhorted Kung to issue a statement to dispel the black cloud of rumors, lest it cause incalculable damage to the contribution campaign and to the bond subscription drive, both of which were underway. ${ }^{13}$

On the following day, Tan received a telegram from Wang Chingwei, who explained:

I am absolutely opposed to surrender. But the pursuit of peace and resistance are not contradictory; they are, indeed, compatible. As long as conditions for a peaceful settlement do not compromise China's independence, why should we not pursue peace? There is no reason why this avenue should not be explored.14

In conclusion, Wang begged Tan to try to understand his position. This explanation, apparently unsatisfactory to Tan, prompted him to write two replies in succession. He strongly condemned Wang's imprudence in speaking out for peace because his gesture would "destroy the determination of the Chinese to fight the war." The language of the second letter was more blunt. Tan charged that Wang's peace gesture was a "concession" which, if accepted, would lead China to national suicide. As a result, China "would be thrown into a chaotic condition and would become a laughing stock. ..." In his accusation, Tan intimated that Wang was guilty of treason similar to "the plot of Ch'in Kuei to defeat Chang Chao." ${ }^{15}$ In a letter to Chiang Kai-shek, the patriarch demanded that the Generalissimo adhere to the letter and spirit of the Loshan Declaration, in which he had vowed that China would resist Japanese aggression for the preservation of the Chinese race, carry out a scorched-earth operation in order to halt the advance of the Japanese troops, and prepare for a protracted war of resistance. ${ }^{\mathbf{1 6}}$ 
Both Chiang and Kung assured Tan of their determination to resist, advising him not to be dismayed by the rumors, and appealed for donations to the war coffers.

In the midst of the verbal war between the NCRGA and Wang Ching-wei, the news of Wang's defection from Chungking in December, 1938, was reported. An editorial in the Hsing Tao Jih Pao (Hong Kong) on December 31, 1938, expressed the Nanyang Huach'iao's opinion of Wang's desertion in the following words:

.. . The Konoye declaration [of Three Principles] on December 22 and the Wang declaration [for the cessation of the hostilities and for peace] are identical in their objectives. Generalissimo Chiang Kai-shek's great speech [making this war a protracted national revolutionary war] dispel any doubt [as to the ultimate goal of China ], and he will crush the sinister plot of the enemy.

Wang's statement is nothing but an admission of his own guilt. What Generalissimo Chiang has said until this war is won 'anyone who speaks for peace is a traitor' is crystal clear to us and must not be forgotten. The action of Wang should neither be acquiesced to nor should it be tolerated by all Chinese abroad. Our task is to eradicate a defeatist element from our rank-and-file. Upon reading the Wang declaration, we overseas Chinese are deeply indignant at him. ${ }^{17}$

Furthermore, a flood of letters and telegrams reached Chungking, demanding the arrest of Wang Ching-wei the traitor. ${ }^{18}$

Following Wang's defection, the Chungking government launched the National Spiritual Mobilization Movement, in February, 1939, to counteract the Wang Ching-wei affair. The KMT government mobilized all available mass media in an attempt to expose Wang's treason and to shatter what the Chinese called an illusory dream of Japan's New Order in Asia. ${ }^{19}$ On May 1, the Nanyang Chinese joined the Spiritual Mobilization Movement by organizing a similar movement throughout Southeast Asia, sponsored by local Chinese consulates and KMT overseas agencies. ${ }^{20}$ Every month thereafter the Chinese renewed their vow to continue boycotting Japanese merchandise, to refrain from reading enemy propaganda literature, and to give their money and strength to China. On July 21, at the height of the movement, Chiang Kai-shek delivered an address designed to boost the morale of Chinese abroad. $^{21}$

Reviewing the "Destroy-Wang Ching-wei" movement of 1939, the Nanyang Siang Poh, in a special issue, summarized the campaign as follows: 
Wang Ching-wei openly rebelled against China and surrendered to the enemy. It was an impudent act to betray the country in order to advance his own personal interest and ambition. Chairman Tan Kah Kee of the NCRGA immediately sent a telegram to the central government, demanding the prosecution of Wang Ching-wei. An anti-Wang campaign has spread rapidly like a prairie fire throughout the South Seas. . . . The will of eight million Nanyang Chinese is united in a determination to fight the traitor and other opportunists. . . Since the beginning of the anti-Wang drive in Malaya, the feelings of the Chinese people have been high. This is evident in the press, in speech-making gatherings, and elsewhere on the streets. The Wang faction has tried in vain to infiltrate into our communities attempting to sow the seeds of dissension, but we, the National Salvation Movement, have proved our strength. Our solidarity in resistance is attributed to the success in the [Spiritual] Mobilization and education. In the past year, the NCRGA has conducted its anti-Wang movement. ...

Since Wang turned against China, speaker after speaker has delivered antiWang speeches every night, and this is a spontaneous reaction. We have observed frequently that youth groups everywhere have presented anti-Wang stage dramas at a fund-raising garden party, and that anti-Wang songs are popular. To sum up, the anti-Wang campaign in Malaya in the past year, in cooperation with the anti-Wang extermination operation in China, has fulfilled its objectives. ${ }^{22}$

This summary may contain some elements of propaganda and selfexultation, but it is an accurate description of the Chinese attitude toward the Wang Ching-wei episode. As the editorial states, Wang did appeal to the Nanyang Hua-ch'iao for their support. He got in touch with Chinese leaders whom he had known since his revolutionary days in the early 1900's. After his defection, he communicated with his friends in the South Seas, and in a defense of his turncoat behavior confirmed his belief in the Konoye Proclamation of Three Principles. ${ }^{23}$ His appeals, however, evoked almost no support in Chinese communities. What little support there was came from persons who, ${ }^{24}$ as a student of the overseas Chinese has observed, were simply expressing their old comradeship with Wang Ching-wei or just making a gesture of courtesy. This critic was skeptical about the ability of these wouldbe supporters to erase anti-Japanese feelings. ${ }^{25}$

Although the Nanyang Chinese had for some time been important to Japan's trade in Southeast Asia, it was the Sino-Japanese war that emphasized their potential political and economic value in Japan's war with the KMT government. The numerous studies and publications that appeared after 1937 were evidence of Japan's interest. Government and semi-government agencies and institutes, private research institutes, and business firms that had anything to do with China and Southeast Asia began intensive studies of the "Nanyang Chinese ques- 
tion." ${ }^{\text {26 }}$ As the war went on, the question of the Chinese in Southeast Asia became a matter of great concern.

From the Japanese standpoint, the Nanyang Chinese were of vital importance for two reasons: they were a primary source of revenue for the Chungking government, providing precious foreign currency with which it could purchase much-needed war materials; and the Japanese government needed their cooperation and wealth for the realization of its program, the Greater Asian Co-Prosperity Sphere. When the Wang Ching-wei government took office in Nanking in March, 1940, it gave top priority to the creation of the Overseas Chinese Affairs Committee, whose purpose was to entice the Nanyang Chinese to support the new government. ${ }^{27}$ Wang Ching-wei appointed Ch'en Chi-ch'eng chairman. Ch'en, a man of no national stature, had few qualifications for the position. Ten days after the establishment of the new government, the chairman announced a new program to encourage overseas Chinese to invest in enterprises in Japanese-occupied China and to protect the property and welfare of the Overseas Chinese. Not much was heard of the activities of the Committee after that, and Ch'en was replaced the following year. His successor, Ch'en Chun-hui, another relatively unknown official, was no more efficient than his predecessor. The fact that the Wang Ching-wei government appointed two relatively unknown chairmen is a good indication that it did not have men who could command the respect of the Nanyang Chinese. As a matter of fact, the committee was so ineffectual that by the end of 1943, the Nanking government had virtually abandoned the project. Neither Tokyo nor Nanking was able to attract the overseas Chinese to its side and to divert their wealth to the areas controlled by the Japanese. $^{28}$

The Wang Ching-wei government, groomed by the Japanese as a focal point for the loyalty of the Nanyang Chinese, was a poor alternative to the Chungking government. The Nanyang Chinese knew that the Nanking government was a puppet regime of Japan, even though it was presented as an "independent" government. Their loyalty to the Chungking government remained unshaken, and they resisted the Japanese until the capitulation of Japan. The Japanese and Wang Ching-wei-despite his close relations with the Malayan Chinese-failed to evoke even lukewarm support. Instead, they 
faced a solid wall of resistance before December, 1941, and apathy during the Japanese occupation. ${ }^{29}$ In this respect, it is interesting to note that Wang Ching-wei, in his address at the Greater East Asian Assembly in November, 1943, did not mention any connection between his own regime and the overseas Chinese but stressed the evils of the Chungking government and the advantages of cooperation with the local Japanese-controlled administration. ${ }^{30}$ Wang appeared to have given up his efforts to entice the Nanyang Chinese to his side.

The attitude of the Nanyang Chinese to the Wang Ching-wei government was in evidence long before the installation of the new regime; on February 4, 1940, the Sin Chew Jit Poh, the Union Times, the Sin Chung Git Poh, and the Penang Git Poh cabled a joint statement to Chungking in which they condemned the "blasphemous crime" of Wang Ching-wei and pledged allegiance to the Chiang Kai-shek government. The cablegram ended with a demand for the prosecution of Wang, the enemy of all the Chinese people. ${ }^{31}$ The Nanyang Siang Poh and the Sin Chew Jit Poh, apparently to counter the impact of the inauguration of the Nanking government, which was scheduled for March 30, attacked Wang, branding him the "traitor of China," and vowed to destroy his government. The Nanyang Shang Poh's editorial asserted that the subversive activities of the Wang Ching-wei regime would not break down the morale of the Chinese people but warned the Chinese to be alert to the enemy's scheme for peace. ${ }^{32}$ When the Nanking regime was established, Chinese newspapers throughout the South Seas opened an intense press campaign against it. They reprinted the "Ten Anti-Wang Slogans" supplied by the Propaganda Department of the Chungking government. ${ }^{33}$ In the meantime, local Chinese consulates and KMT agencies had taken measures to forestall the infiltration of the Nanking government's agents, who were reported to have smuggled anti-Chiang Kai-shek literature from Japanese-occupied China to Malaya. ${ }^{34}$ The KMT officials also discouraged Chinese from returning to China through ports in the Japanese-occupied area and encouraged them to remit money through Chungking-controlled banks and facilities so that it would not fall into the hands of either the Japanese or the Nanking government. ${ }^{35}$

In summary, the Wang government and the Japanese policy found little support in Nanyang Chinese communities. Wang's defection 
and the establishment of his regime provided the Chinese in Southeast Asia with the opportunity to renew their loyalty to Chiang Kaishek. Lum Mun Tin, treasurer of the NCRGA, expressed the general sentiment of the Nanyang Chinese toward the war: "We do not want peace through humiliation [such as Wang Ching-wei has offered to us]; we want an honorable peace." ${ }^{36}$ Never had the national consciousness of the Nanyang Hua-ch'iao been so high, and never had the KMT enjoyed so much prestige and support.

On the one hand, increasing KMT interference in local affairs of the Nanyang Chinese created divisions between local leaders and KMT leaders; on the other, it deeply disturbed local governments which tried to avoid a diplomatic complication with Japan. Furthermore, local authorities had misgivings about the dominant role of Communists in the anti-Japanese National Salvation Movement, which had become conspicuous especially after the united front had been completed by 1938 .

In the following pages I shall survey the development of the antiJapanese National Salvation Movement after the formation of the NCRGA, trace the KMT and Communist activities in it, and describe the response of local authorities.

\section{The Straits Settlements and Malaya}

As has been noted in the previous pages, the Malayan Communists succeeded in forming a united front with non-Communists within the Chinese community. ${ }^{37}$ In April, 1939, the Party's Sixth Enlarged Plenum adopted a ten-point Program of Struggle which established an "All-Races United Front to strive for a democratic system, to safeguard peace, and to implement action against the Japanese-German-Italian Fascist bloc." This Plenum also established "a new party leadership under the controversial Loi Tek. . .."38 Communist influence was fast growing within the Chinese community, and the Party had become respectable among Chinese who otherwise would not be enamored of Communists because Communists had united with $\mathrm{Na}$ tionalist Chinese to oppose the Japanese. To the British colonial authorities, the united front situation presented a difficult problem. They could hardly repress the anti-Japanese activities of the Chinese even though they knew that Communists were instigating the Chinese 
behind the scenes. However, a change in tactics, adopted by the Malayan Communist Party (MCP) in September, 1939, reflecting the conclusion of the Soviet-German Non-Aggression Pact, ${ }^{39}$ gave the British authorities an opportunity to move against the Communistcontrolled anti-Japanese operation. For instance, in December, the colonial authorities expelled Kow Say Huan, an Executive Board member of the NCRGA and a leader of the Vanguard Brigade, an auxiliary of the Anti-Enemy-Backing-Up Society, on the grounds that he was active, under an assumed name, in the illegal Vanguard Brigade and that he associated with Communists. ${ }^{40}$ In February, 1940, prominent leaders of the Penang Chinese Relief Fund-Raising Association were deported from the colony under the Banishment Ordinance. ${ }^{41}$ Nor did the growing vociferousness of the Chinese, inspired by their country's struggle against Japan, please the native Malays; indeed, it aroused their hostility. For example, the school authorities of the Johore state government took a serious view of reports that Chinese schools in the state had been using anti-Japanese textbooks and singing anti-Japanese songs to inculcate anti-Japanese spirit in the children. After an investigation, the state government notified the Chinese administrators that it would not permit the use of any teaching material that would help stir up feeling discriminatory against or injurious to the Japanese, warning that it would prosecute them for future violations. ${ }^{42}$

Meanwhile, war broke out in Europe. The MCP, at a conference in February, 1940, worked out a new policy to meet the situation. Elaborating its anti-imperialistic policies, the Party appealed to the Chinese to concentrate on helping China within the context of the All-Races United Front (now changed to the Anti-Imperialist Racial United Front) and called upon Indians and Malays to carry out their anti-British drives. ${ }^{43}$ The Communist assault on the British, however, did not continue during the effective period of the Nazi-Soviet Pact. As early as the summer of 1940, the MCP found it necessary to modify its earlier anti-British stance because of the change in the international scene. In July the Chinese Communist Party advised the MCP to "call off its strikes and other anti-British agitation in view of Britain's current aid to China and the importance to Chungking of gaining London's intervention in the opening of the Burma Road," ${ }^{44}$ and 
"henceforth ... to concentrate on consolidating the anti-Japanese front and to support the National Salvation Movement. . .."45 The changing international political situation since the outbreak of the war in Europe in the previous year produced an about-face in party policy, leading to the cultivation of the goodwill of Britain and emphasizing the Chinese anti-Japanese activities. The fact that the MCP had complied with the Chinese Communist Party's directive seems to be, as Brimmel writes, "the first clear example of the Chinese Party's taking over the functions of the Comintern in South East Asia."

The MCP's compliance with the new Chinese Communist strategy meant that the Chinese Communist Party henceforth would directly involve itself in the Nanyang Chinese National Salvation Movement, guiding the MCP from the South China Bureau of the Communist Eighth Route Army in Hong Kong. ${ }^{47}$ Chances for an effective united front National Salvation Movement would have looked better, provided that the KMT and Communists had collaborated closely. However, the two worked at cross purposes, intent on destroying each other. The struggle between the two parties dampened Nanyang Chinese patriotism, disappointing many oversea compatriots and splitting the unity of the National Salvation Movement. The MCP was determined to enhance its position through its appeal to nationalism and united front tactics (which also insured a certain immunity from police interference). Its strategy appears to have paid off, judging from the increase in party membership, which by May, 1940, had increased to fifty or sixty thousand and enjoyed the support of over one-hundred thousand Chinese sympathizers. ${ }^{48}$ Another maneuver was to drive a wedge in the Chinese community leadership circles, creating a split among the leaders. The ultimate objective of this was to extend Communist influence at the expense of the KMT. The episode of Tan Kah Kee was an example.

Evidently to cope with Communist expansion, the Chungking government sent Wu T'ieh-ch'eng, Minister of Overseas Party Affairs, to Malaya in the early months of 1940 . His mission was ostensibly to solicit contributions and bond subscriptions, but his real purpose was to strengthen KMT influence through "the so-called Tang-hua chiaoyü or Party-transformed Education of Malayan schools."49 After his arrival, a KMT affiliated youth organization known as the San-Min- 
Chu-I Youth Corps was introduced into Malaya. ${ }^{50}$ After his departure, the Youth Corps carried out large-scale party activities. ${ }^{51}$

The KMT further attempted to assert its influence over the $\mathrm{Na}$ tional Salvation Movement in June, 1940, when the Nationalist government issued "Principles Governing People's Organizations During Emergency Time." Article 9 of the Principles made it plain that the new ordinance would apply to overseas Chinese associations. Under Articles 1, 4, and 11, all Chinese associations were to be subordinate to the Nationalist government. ${ }^{52}$ The conspicuous hand of the KMT in the Malay Chinese National Salvation Movement seemed to irritate a proud man like Tan Kah Kee, who was perfectly capable of organizing anti-Japanese activities without help from the KMT government. Tan had other reasons for disliking the KMT and for becoming disillusioned which may have helped drive him into the arms of the Communists. He was a severe critic of Ch'en Yi, the governor of Fukien, his home province, from whence millions of Chinese emigrated to the South Seas region. The governor's repressive policy enraged many Chinese in Southeast Asia. Subsequently, Chinese associations in Manila and Malaya jointly sent a telegram to Chungking, demanding that Ch'en Yi be removed from office. ${ }^{53}$ Though Ch'en was dismissed (but not until 1942), Tan continued to attack the KMT maladministration of his native province and its impotence in the war. He became more and more critical of high KMT officials surrounding Chiang Kai-shek and more laudatory of Mao Tse-tung, whom he visited at Yenan during his nine-month fact-finding trip to China in $1940 .^{54}$ Tan's unhappiness with the KMT was aggravated by the deterioration of the tenuous KMT-Communist coalition, evidence of which was already manifest as early as October, 1940, when Tan was in China. It culminated in the incident of the New Fourth Army slaughter in January, 1941.

It is worthwhile to dwell upon the erosion of Tan's relations with Chungking government officials to see how he became enamored of the Communists and alienated from the KMT. Tan left for Chungking in late March, 1940, to start a nine-month observation trip of China. As general director of six comfort groups, he travelled with one of the groups until mid-July. Thereafter, accompanied by Kow Say Huan, who had been deported by the British authorities because 
of his involvement in terrorism and Communist activities, Tan travelled from the high plateau of the Northwest to the shore of the Southeast, meeting with high dignitaries of the Nationalist government and the Communist regime..$^{55}$

From Tan's memoirs, from reports from China, and from other sources, it can be deduced that he was not generally satisfied with what he had found in China. Three things, however, grieved him most deeply - the deteriorating united front, conditions in his native province of Fukien, and conditions on the Burma Road. After his return from the Northwest, as revealed in a press interview on October 4, Tan hastened to visit Yenan because of his concern for the state of the KMT-Communist coalition, which had been plagued with incessant friction. According to one account, Chiang Kai-shek opposed Tan's proposed trip to the Chinese Communist wartime capital and tried to prevent his visit to Yenan, denouncing the Chinese Communists as evil. Tan, however, explained that he was on a fact-finding mission and that he was obliged to report to his compatriots what he had seen in China-including Yenan. It was from this time on, the account continues, that the KMT government attempted to obstruct his fact-finding activities and to put him under surveillance wherever he went. ${ }^{56}$ During a week's stay at Yenan, Tan exchanged views with Mao Tse-tung, chairman of the Chinese Communist Party; Chu Teh, commander-in-chief of the Chinese Red Army; Chou En-lai, vicechairman of the Military Committee; and Wang Ming, a top party official. When Tan "admonished them with tears" to stop their internal quarrel with the KMT, they all assured him of their support of Chiang Kai-shek and the Chungking government. ${ }^{57}$ Tan left Yenan with the conviction that the antagonism would cause no more problems. ${ }^{58}$ But it is not surprising that he was impressed by the austerity and discipline of the wartime capital of the Communist regime, accustomed as he was to the moral laxity in Chungking-controlled China. Although he had had connections with the Communists through his anti-Japanese organizations and through Kow Say Huan, ${ }^{\text {59 }}$ there is no convincing evidence that he turned to Communism after his visit to Yenan in 1940.

If there was a turning point in his long career as the leader of Nanyang Chinese communities, it was his visit to his native province 
of Fukien, which he had not seen for nineteen years. Tan recorded in his memoirs his distress over the miserable conditions in Fukien under the graft-ridden administration of General Ch'en Yi. The land tax, he wrote, was exceedingly high, and the tax assessment was arbitrary. People were suffering from taxes paid in silver as well as from the soaring and unstable price of rice. He denounced the corrupt provincial administration for operating a transport company, which competed with private companies, driving them out of business and forcing up the prices of consumer goods. As a result, people were starving, and some desperate citizens committed suicide. Tan reported that no one dared speak up for fear of reprisal. Such were the conditions that on several occasions moved Tan to write to Chairman Chiang Kaishek and President Lin Shen. He demanded an immediate correction of the conditions, which, he said, should not be allowed to exist in wartime China. He also confronted Ch'en Yi with demands that he take steps to eradicate the corruption in Fukien province. ${ }^{60}$ Though Tan received replies from Chiang, and Ch'en Yi was eventually removed, the damage had been done.

At the conclusion of the journey that took him into fifteen provinces, Tan, in his speech before the legislative body of the Nationalist government, praised Chiang Kai-shek but rebuked his advisers for incompetency. ${ }^{61} \mathrm{He}$ criticized the poor administration and maintenance of the Burma Road, despite his earlier recommendations for improvement to higher authorities. ${ }^{62}$ His harshest condemnation fell upon the corrupt Fukienese government and central government officials, on greedy merchants in Chungking, on demoralized youngsters, and on stifling press censorship. He said that the press was so severely censored that newspapers were not fulfilling their function; that although the Nanyang Chinese were united in the boycott drive, much enemy merchandise was publicly displayed and sold because greedy merchants were in collusion with corrupt officials to fatten their purses; that high officials and their wives were squandering money night after night at the state guest house, which was managed by Kung Hsiang-hsi; and that men were still wearing the Manchu uniform and short coats, and women were wearing long robes, highheeled shoes, nail polish, and so much perfume that they were seductive! $!^{63}$ Then Tan found another opportunity to express his opinions 
when he was asked to speak about his trip to the northwest before a meeting sponsored by the China Foreign Relations Association. He praised Communist-liberated areas, where oppressive taxes had been abolished, education promulgated, irrigation improved, and agriculture developed, where friendly relations existed between soldiers and citizens, and officials were honest and unselfish. Then he chided KMT reactionaries who persisted in opposing the united front at a time of national crisis, appealing to all political parties to unite at once to resist the enemy and to settle their disputes after China's victory. ${ }^{64}$

These blunt remarks were reported to have caused consternation among the government officials. Subsequently, according to Tan, the KMT government, through its consulate, asked the British authorities in Singapore to deny him entrance to the city because he was a Communist sympathizer. Immediately following this request, the KMT government sent General Wu T'ieh-ch'eng, Minister of Overseas Party Affairs, to Singapore, where he attempted to interfere with a welcomehome ceremony for Tan and canvassed for the election of NCRGA officers in order to unseat him. ${ }^{65}$

The New Fourth Army incident in January, 1941, in which the KMT troops attacked and killed many Communist soldiers, was for Tan another source of disappointment in the Nationalist government. His observations on the incident indicate that he was ready to break away from the KMT government. This state of his mind was corroborated by a train of events taking place from January to April. $\mathrm{He}$ placed the blame for the attack squarely upon both "pro-Japanese and anti-Japanese elements" in the KMT government; viz., Ho Ying-ch'in, chief of the General Staff, and Pai Ch'ung-hsi, deputy chief of the General Staff. ${ }^{66}$ He called the incident a "conspiracy" hatched by the proJapanese faction who wanted to surrender to Japan, not to re-arm a "genuine anti-Japanese people's army," the New Fourth Army. ${ }^{67} \mathrm{He}$ seemed certain that because General Ho and General Pai were less anti-Japanese than they were anti-Communist they did not want Communists fighting on the KMT side against the Japanese. ${ }^{68}$ Tan had drifted away from the KMT government, but he had not embraced Communism, although his interpretation of the New Fourth Army incident was much closer to that of the Communists than to that of the KMT. ${ }^{69}$ 
Then in February, Tan suddenly and dramatically announced his intention to resign from all public offices connected with the Nationalist government. ${ }^{70}$ His announcement seemed to be a somewhat theatrical gesture to counteract rumors, allegedly spread by Wu T'ieh-ch'eng, branding him a Communist and a traitor. ${ }^{71}$ It appears that he sought to force the KMT-Communist issue in order to allow the Nanyang Chinese to judge him; it was a calculated move to decide the issue of the united front which he had supported and in which all Nanyang Hua-ch'iao had a stake. He threatened to resign if he did not get a vote of confidence. Moreover, he was indignant because his integrity had been questioned, and he denounced General Wu and Consul General Kao for calling him a Communist. At the opening meeting of the second congress of the NCRGA, held in Singapore in late March, to which 87 associations sent 164 delegates, he not only reiterated his criticism of the corrupt KMT officials, landlords, and profiteers in Fukien province, and of the KMT government's ignorance of conditions in the lower strata, ${ }^{72}$ but also attacked General Wu's wartime record as the governor of Kwangtung province. General Wu, he revealed, had removed his personal belongings in military vehicles and abandoned the populace of Canton to the advancing enemy troops. ${ }^{73}$

Tan's unexpected resignation and his charges against KMT government high officials at the NCRGA were a bombshell, evoking a mixture of astonishment, disbelief, and chagrin, and endangering the unity of both the Nanyang Chinese National Salvation Movement and Chinese communities. Consul General Kao, who was present on the opening day of the NCRGA meeting, replied to Tan's charges, admonishing the delegates "not to destroy a unity ... by spreading words detrimental to the sacredness of the [Chinese] state." And, without mentioning Tan's name, he warned him that: "It is unpardonable to attack the government's internal matters in the name of patriotism and national salvation. It is anachronistic to maintain non-sectarianism [at the time of the national emergency]." ${ }^{\text {" }}$ Kao's criticism of Tan's policy of non-favoritism to either the Nationalists or the Communists and his intimation that Tan was deceitful threw the conference into an uproar. $^{75}$ The following day, Tan denounced the Consul General, saying that he had "insulted the Chinese compatriots abroad," and proposed that Kao's speech be censored and Kao barred from the con- 
ference. $^{76}$ The motion passed, and the Consul General was shut out for the rest of the session. Meanwhile, General Wu categorically denied the allegation and joined the chorus accusing Tan of having supported Chiang Kai-shek with "his lips but not with his heart."77 Local Chinese newspapers, too, were divided on the controversy. The Sin Chew Jit Poh, Aw Boon Haw's paper, upbraided Tan, claiming that his contempt for the Consul General was tantamount to an insult to the Chinese state, ${ }^{78}$ but the independent Hsien Tai Jit Poh of Penang demanded that General Wu be executed before a firing squad. ${ }^{9}$ Tan's re-election to the chairmanship of the NCRGA was proof of his vindication. Tjong See-gan and Yu Khe Thai were vice-chairmen.

The attack upon Ch'en Yi and his Fukien government officials continued at the Nanyang Fukienese Chinese General Assembly, which convened on April $1 .^{80}$ The Assembly gave unanimous support to Tan's demands for reform in Fukien province and for punishment of the evil officials, but it paid tributes to Chiang Kai-shek and Lin Shen, pledging its support of their gallant resistance. ${ }^{81}$

The Tan-KMT rift caused bad feelings between the Fukienese Chinese and the Chungking government, but it did not do irreparable damage to Nanyang Chinese-Chungking relations. ${ }^{82}$ Tan did not attack Chiang Kai-shek and Lin Shen during his quarrel with Consul General Kao and General Wu; in fact, he and his organizations committed themselves to the government at Chungking. The reason for what appeared to be statements sympathetic to the Communist position was his strong attachment to his native province and to China, whose moral fiber was being weakened by venal bureaucrats in the midst of the war. Having been active in relief projects and economic and welfare programs for both Fukien province and China for many years, Tan could not tolerate corruption, exploitation, and incompetence in either the KMT or the Communist Party. His first loyalty appears to have been to China, not to a particular political party, as he declared at the second NCRGA meeting. "If the Chinese want security in the South Seas," he said, "the fatherland must be defended first, and the situation in Southeast Asia will improve when the situation in China turns better." 83 It goes without saying that Tan supported Chiang Kai-shek because he respected Chiang as the leader of China and as the personification of China's nationalism, not because he ad- 
mired Chiang's personality and beliefs. There was no evidence that Tan disliked Generalissimo Chiang, and the two leaders had a mutual respect. That respect explains why Tan did not criticize Chiang Kaishek but supported his leadership and why he told Chou En-lai in Yenan that his position was that of $P u$-p'ien-pu-tang (favoring no party). Tan's remarks in praise of the discipline of the Communist Chinese and in denunciation of the laxity of the KMT Chinese were the natural response of a man who admired high standards of morale and competence. His statements are to be viewed in that context; therefore, it seems, Brimmel erred when he said that the Tan-KMT dispute was "the beginning of the transference of Chinese nationalist allegiance from the Kuomintang to the Chinese Communist Party ...."84 Neither Tan nor his Nanyang compatriots were preparing in 1941 to transfer their allegiance either to the KMT or the Chinese Communist Party; they were committed to China. It is true that in 1941, Tan was more sympathetic toward the Chinese Communists than he had been in $1939,{ }^{85}$ as his continuous association with Kow Say Huan, with whom he travelled to Yenan, and his comments on Communist Chinese discipline and on the New Fourth Army incident showed. Although he may have been a sympathizer, he was not in 1941 an ideological Communist sympathizer. ${ }^{86}$ To what degree Communists in Singapore helped drive a wedge between Tan and KMT officials is a moot question. That they strengthened their position and profited at the expense of the KMT is undeniable.

Meanwhile, relations between the British authorities and the Chinese community had deteriorated, partly because of an eruption of intense Chinese anti-Japanese activity directed by the San-Min-Chu-I Youth Corps $^{87}$ and partly because of Chinese resentment of a British decision to set the ceiling on remittances at SS $\$ 250$ per person. ${ }^{88}$ The British authorities felt uneasy about the intensified anti-Japanese campaign because it strained Britain's relations with Japan just when Tokyo was increasing pressure on Britain to close the Burma Road. From the summer of 1940, to the summer of 1941, the San-Min-Chu-I Youth Corps stepped up both anti-Japanese and anti-British campaigns. The British authorities were obliged to take a repressive measure against the Corps in June, 1941, and in November, the British sent a mission to Chungking to adjust Sino-Anglo relations. When the 
mission returned to Singapore, nothing was said about ironing out the differences in the government's relations with China. Because war with Japan was imminent, Britain was no longer in a mood to employ a policy of neutrality. ${ }^{89}$

The Japanese invasion of Malaya on December 8, 1941, ended Tan's rift with the KMT, and it brought the British and Chinese together for the defense against a common enemy. On the same day, Chiang Kai-shek addressed the Nanyang Chinese by radio, ordering them to mobilize their resources to resist the invasion" because the "victory of the Allies means our victory." ${ }^{11}$ Four days later, General Wu T'iehch'eng urged his overseas compatriots to "cooperate with local authorities" to defend Malaya and Singapore against the Japanese. ${ }^{92}$ Only the Chinese could understand the call because they were threatened by the Japanese, who were the enemy of China, their mother country, which had been fighting for four-and-a-half years. The Nanyang Chinese, one observer said, "were all sympathetic to Free China's causes and had been greatly stirred by her gallant struggle." ${ }^{93}$ A group of Singapore Chinese community leaders visited Sir Shenton Thomas, the Governor General, and told him that they had agreed to sink their common differences and to give every support to the local government in the prosecution of the war. ${ }^{94}$ Encouraged by the surge of national spirit, the Governor General invited Consul General Kao and Yeh Kung-ch'ao, chief of the KMT Information Bureau at Singapore, to request Chinese assistance for defense against the Japanese army, which was advancing very rapidly southwards. ${ }^{95}$ The three having reached an agreement, Kao and Yeh asked Tan Kah Kee to organize a committee to implement the agreement of cooperation. The outcome was the formation of the Chung Kuo Council for General Mobilization on December 31. The primary objective of the Council was to mobilize Chinese resources for the pursuit of the war. Ian Morrison, a British war correspondent, reported that Chinese under the Council's direction did excellent work in supplying the British with laborers for building defense. ${ }^{96}$

It is not clear, however, whether Chinese leaders in Singapore demanded as a price for cooperation that the British authorities immediately release Chinese political prisoners-including Communists -from the Changi Gaol or whether the British authorities freed them 
out of humanitarian consideration. Circumstantial evidence seems to support the former conjecture. The British soon freed Chinese prisoners from Changi and welcomed the Communists whom they had so recently suppressed. The British did know "the great influence which the Malayan Communist Party still wielded amongst the poorer sections of the Chinese population," and the Party had an excellent organization in these people, through which the British could mobilize them. Acting as an agent for mobilizing Chinese for civil defense, the local government de facto recognized the Party, which had been illegal. The Communists now joined the British and non-Communist Chinese residents, voicing their determination to give wholehearted backing to the colonial government in the war against the Japanese invaders. ${ }^{97}$

When the Japanese invasion of Singapore was imminent, the local government decided to call Chinese volunteers and to arm them for fighting. Morrison later described Chinese response to the appeal in the following words:

The call for volunteers provoked an immediate and wide spread response. The volunteers were all sorts, labourers and students, middle-aged men and boys in their teens. . . . There were guerrilla experts from China, sent down to Singapore by the Chungking government to teach guerrilla warfare. Most of the volunteers came either from the Kuomintang or from the Communist organizations. ${ }^{98}$

Under the command of Colonel Dalley, officials of the Malay Civil Service, the Forestry Service, and the Malay Police, and young planters from up-country trained these Chinese, who were destined to become the nucleus of the Malayan People's Anti-Japanese Army. ${ }^{\text {99 }}$

Meanwhile, a large number of the Chinese had enlisted in a small force of irregulars, organized by the Chung Kuo Council, which was directed by ten KMT and ten Communist members, including Tan Kah Kee and Loi Tek, the Secretary General of the Communist Party. ${ }^{100}$ According to Colonel Sugita Ichiji, a Twenty-fifth Army senior staff officer in charge of intelligence, these irregulars, operating as espionage agents on the mainland of Malaya, "effectively" obstructed Japanese military operations behind battle lines. ${ }^{101}$ In the battle of Singapore, both volunteers and irregulars left for their battle stations singing a song which had been especially written for the occasion: 
Arise, arise, those who do not want to be slaves. Build a new Great Wall with your flesh and blood. ${ }^{102}$

Many units fought to the last soldier; a Chinese volunteer platoon made a gallant stand against the invaders in the north of Singapore until all perished. Others, including Tan Kah Kee, gave up the futile resistance. ${ }^{103}$ After sending to China the 13 million yuan that had been collected in a contribution campaign begun in early December (this drive terminated in late January, 1942), Tan escaped from Singapore to Sumatra in a small ferry boat on the night of February 2. From Sumatra he went to Malang in Java, where he hid from the Kempeitai until the end of the war. No one blamed him for leaving Singapore, however. After the capitulation of the British fortress, thousands of Chinese were arrested in a series of Kempeitai roundups in February and March, and hundreds were executed for anti-Japanese activities between 1937 and $1941 .^{104}$ Summarizing the Chinese fighting spirit, Morrison, who witnessed Chinese fighting the Japanese troops in Malaya-Singapore, wrote:

They had what the Indian and Malay troops lacked, a personal venom against the Japanese, who for over four years had been killing their fellow-countrymen in China. They were inspired by something which nearly all the other fighting forces lacked. ${ }^{105}$

\section{The Dutch East Indies}

The KMT and the Communists were less active in the Netherlands Indies than in the British territories. Although the KMT-financed Chinese press had been vocal in appealing to the Indies-Chinese to boycott, the boycott hurt Japan's trade with the Dutch colony less than it hurt her trade with Malaya and the Philippines. Communism was also weak because the Indonesian Communist Party and other leftwing organizations were too feeble to provide leadership. Moreover, the Dutch authorities were so strict in suppressing political movement, regardless of its coloration, that during 1938 and 1939, the Communists complained of the "pro-Japanese views" of Dutch officials and of their restriction of the anti-Japanese movement. ${ }^{106}$

The Communist charge of "pro-Japanese views" was not accurate. The policy of the Netherlands government was to avoid giving Japan an opportunity to establish a large-scale propaganda beachhead in the Indies, where she was known to have been giving secret aid to an 
indigenous national independent movement. ${ }^{107}$ To minimize the chance of Japanese intervention, the Dutch restricted both Chinese and Japanese activity. For instance, the government banned the teaching of political ideology in Chinese schools as well as the political activity of Chinese teachers, and it prohibited the public sale of twelve anti-Japanese books and magazines. ${ }^{108}$ The Dutch authorities were equally uneasy about increasing Japanese intelligence activity and a propaganda drive, organized by the Japanese Foreign Office and military, to attract local Chinese youths to the Tokyo-Nanking alliance. ${ }^{109}$ The Japanese Foreign Office-subsidized Higashi Indo Nippo "systematically" maintained an anti-Chiang Kai-shek editorial policy. The inauguration of the Wang Ching-wei regime accelerated the Japanese campaign with the official blessing of the Koain, in cooperation with the Japanese Army and Foreign Ministries. The Foreign Ministry sponsored a Japanese tennis team's trip to the Indies, where the team played Chinese teams to promote friendship. The Government and related agencies seriously considered a cultural exchange program with the Indies, like the one with the Philippines. Chinese athletes, students and teachers would spend a summer in Japan, and Japanese teachers would teach in Chinese schools in the Dutch colony. ${ }^{110}$ An official Dutch document describing Japanese subversive activities among the Chinese reads:

The Japanese ever since the occupation of Southern China . . . had special means to influence the Chinese residents in the Netherlands Indies. . . . They tried to estrange those Chinese from the government of General Chiang Kai-shek and transform them into followers of the pseudo-Nanking regime. This was done partly by encouraging them to invest in the occupied Southern China section and guaranteeing their safety of person and belongings; and partly through pressure in the form of a threat of confiscation or action against the relatives at home.

[The] local organization of the so-called Kōain, the council for the elevation of Asia, . . . in cooperation with the Army and the Ministry of Foreign Affairs ..., is charged with the execution of the policies of the Japanese government toward the Chinese.

There is not the slightest doubt as to the nature of these politics in the light of the instructions of the Japanese Foreign Ministry of the 21st of June, 1939, regarding control on the politics concerning the overseas Chinese. ${ }^{111}$

On the other hand, Yoshizumi Tamegoro, ${ }^{112}$ the editor of the Higashi Indo Nippō, who had been active among the Chinese, disagreed with the official approach to propaganda. He argued that most Chinese in 
the Indies had fused with the Netherlands Indies, and that they wanted "to become East Indians before anything else. . . ." Therefore, he urged, "let us make use of the common fate of Indonesians and Chinese and arouse their enthusiasm for the construction of a new Asia." 113 Neither the official policy nor Yoshizumi's plan won the Chinese over to the Tokyo-Nanking alliance to a significant degree before war broke out in December, $1941 .^{114}$

The Chinese persisted in the National Salvation Movement. Irritated by the dogged National Salvation Movement and its professed support of the Chiang Kai-shek government, the Japanese kept pressure upon the Dutch government to "exercise rigid control"115 over Chinese residents' "pro-Chiang Kai-shek and anti-Japanese attitude," and complained as late as August, 1941, of what they regarded as the "pro-Chinese and anti-Japanese" posture of the Dutch government. ${ }^{116}$ The Chinese were, however, aware of their limitations in carrying out the boycott against Japanese merchandise because of the political conditions under which they lived, as Tjong See-gan, vice-chairman of the NCRGA, admitted at the first NCRGA meeting, in October, 1938. ${ }^{117} \mathrm{He}$ was quoted as having said that Indies-Chinese participation in a politically oriented boycott could not match that of compatriots in other countries. Upon his return from Singapore he and other delegates were interrogated by the Dutch police. Consequently, the Chinese concentrated, in response to the Chungking government's requests, on the cash-and-material-donation campaign.

In Batavia, the Chinese Charity Committee asked the Chinese community to economize on New Year's festivals, weddings, and funerals and to donate the money saved. The Batavia Charity Committee also mobilized school children for the contribution campaign. Organized in squads, as were children in Malaya, they solicited contributions on Chinese national holidays and festival days. They had collected 36,000 guilders by late December, 1937. In 1938, they collected 140,000 guilders and in 1939, 50,000 guilders. ${ }^{118}$ Still another method was one of special contributions on such occasions as the visit of Wu T'ieh-ch'eng to Java and the presidential recognition of Consul General Ko for his distinguished work in raising money. At the reception in honor of General Wu, in October, 1940, Chinese raised six million yuan. While the general was in Java, from October 18 to November 14, 1940, more 
than twenty million yuan was collected. Chinese communities in Java also raised 60,000 yuan at a party in January, 1941, celebrating the promotion of Consul Ko. ${ }^{119}$ No opportunity to collect from the Chinese was overlooked; proceeds from athletic competitions, concerts, stage shows, movies, garden parties, art exhibits, and Chinese chess games all went into the treasury of the Chinese government.

The donation of quinine or of money to buy it continued, but each year the contributions decreased. In 1939, Indies-Chinese sent several million tablets of quinine worth about 400,000 guilders; in 1940, they sent approximately 130,000 guilders' worth. Contributions for the purchase of winter clothes in 1939 and 1940 totaled 60,000 guilders. ${ }^{\mathbf{1 2 0}}$

Those facts show that the Chinese were participating in the National Salvation Movement as late as 1941, although the boycott had long before ceased to be effectual. It was so weak that it posed no threat to Japanese trade. The cash contributions, too, began to decrease in late 1938. That decrease indicates a weakening of Chinese financial capability. However, a drop in contributions should not be regarded as evidence that the Indies-Chinese had lost interest in China. That General Wu was able to solicit twenty million yuan in less than one month in the fall of 1940 disproves such an interpretation. It is also to be noted that Consul Ko appeared to enjoy an excellent relationship with the Chinese community and its leaders. The proof is the fact that Chinese in Java raised 60,000 yuan to celebrate Chiang Kai-shek's recognition of Ko's distinguished work. From this limited amount of information, we can deduce that the longevity of the Chinese National Salvation Movement can be in part attributed to Consul Ko's close personal relationship with leaders of the Chinese community.

There is very little information on the National Salvation Movement in the outer islands. Fragmented reports tell that Chinese in northern Sumatra, particularly those in Medan, organized the Federation of Chinese Associations for the Relief of China when war engulfed Southeast Asia. ${ }^{121}$ According to those reports, Chinese undertook a variety of anti-Japanese activities, under the leadership of a five-man board of directors cooperating with the Chinese Consulate and the KMT. Chinese in other cities and towns (Tandjoengbalai, Langsa, Pematang Siantar, Padang, Palembang, and Pangkalpinang) followed the example of the Medan Chinese. Like many Chinese leaders in 
Java, most of the Chinese who had been active in the National Salvation Movement were caught unprepared for the swift Japanese invasion and conquest. A number of them were arrested in the weeks and months following the conquest. In northern Sumatra, five prominent Chinese (one of them was Tjong Ch'ing-te) who composed the board of directors of the Federation were in a group of fifty-nine captured by the Japanese. Twenty-eight were released when they "pledged loyalty to Japan." In southern Sumatra, the Japanese gendarmarie rounded up thirty-three leading Chinese, eliminating, in all likelihood, the core of the Chinese leadership in Palembang. Many are believed to have been executed.

\section{The Philippines}

By the time the Sino-Japanese war was a year old, an economic boycott had spread throughout the Philippine Islands. The boycott and inspection were so competently administered that by September there was little movement of Japanese merchandise. In order to achieve even better results, the Philippine Resist-the-Enemy Committee issued in October new boycott regulations to supplement rules promulgated earlier in the year. ${ }^{122}$ The new boycott regulations closed loopholes and stiffened the penalties for violation. They also gave boycotting committees and the resist-the-enemy committee more power in enforcing the boycott. For instance, Chinese merchants were forbidden to buy Japanese goods through European and American firms, and a piece of merchandise was declared an enemy article if one-tenth of its content was raw material of Japanese origin. A truck owner was subject to punishment if he allowed his truck to be used to transport Japanese goods. A person who violated the new regulations would be branded a traitor; his name, address, and domicile in China would be made public; and the Chinese government would be notified that punishment had been administered. Members of the committees were empowered to inspect the stores of suspected violators. As a result, Japanese businessmen felt the impact of the tight boycott regulations, particularly after holiday seasons. Their situation was serious enough to disturb Consul Kihara, who had been lobbying to prevent the passage of an unfavorable immigration bill. For funds, he relied heavily on local Japanese companies. Partly because "Japanese com- 
panies in the Philippines were being seriously affected by a Chineseinstigated anti-Japanese boycott," Consul Kihara found that "a shortage of locally available funds" forced him to ask the Foreign Ministry in Tokyo for money. ${ }^{123}$

In May, 1939, the PREC found it necessary to draft new rules for stricter enforcement of the boycott-Regulations Governing the Purge and Registration of Enemy Goods. ${ }^{124}$ Under the new rules, Chinese merchants were required to register within five days the description, quantity, trade marks, and prices of their stocks. The passage of the two boycott regulations in seven months may indicate that there were still some opportunistic Chinese merchants who could not miss an opportunity to make money by selling Japanese articles or some dissident ones who did not consider the boycott effective in harassing Japan or aiding China. According to a Japanese source, since the beginning of May some Chinese merchants in the Philippines had been importing from Shanghai Japanese shirts, towels, shoes, and other goods labeled "Made in Shanghai" at a discount of 30 per cent because of the exchange rate of the yen on the Shanghai market. ${ }^{125}$ It also appears that the passage of the rules requiring the registration of enemy merchandise was a move to counter Wang Ching-wei's peace appeal to Nanyang Chinese communities following his defection from Chungking in December, 1938. Some Chinese, particularly older ones who still owned property in Fukien province, were said to be sympathetic to Wang's peace move. According to reports, they were reluctant to participate in the National Salvation Movement and secretly supported Wang Ching-wei but were afraid to speak out because they feared public accusation and the desecration of their ancestral graves in Fukien province. ${ }^{126}$ Although the boycott in the Philippines continued, there were signs that enthusiasm for it was faltering; and in early 1941, it began to lose its effectiveness. The decline was owing partly to limited Chinese capital, which could not endure a prolonged boycott, and partly to the probability of an American-Japanese war.

As in the British colonies, KMT influence was on the rise in the Philippines until 1937. In the early 1930's the Philippine Chinese KMT was led by Ong Chuan-sien, the principal of the Chinese National School; Tai Kui-sheng (Tai K'uei-sheng), later the vice-minister of the Department of Overseas Affairs; and Tai King-hwa (Te Kin Fue 
or Te Kin Hua), Tai Kui-sheng's uncle and the manager of the KMT paper, Kong Li Po. ${ }^{127}$ Upon appointment to the KMT Executive Committee, Ong relinquished his post in the KMT headquarters in Manila and returned to China. Subsequently, a young group took over. In 1940, Sy Yat-sien, a former insurance agent; Sai Kuo-ch'üan, proprietor of the Indianhead Textile Co.; and Tan Unliong, president of the Tan Family Association and owner of the Tien-tan Lard Manufacturing Co., were members of the Standing Executive Committee. Moreover, Sai held an office in the General Affairs Department; Sy, in the Organization Department. Tseng T'ing-chüan was listed as chief of Propaganda and Cua Chün-ti, a former teacher in Cebu, as secretary. ${ }^{128}$

Despite the KMT's secure position in the Chinese community, difficulties with local party members and business leaders arose soon after Ong left Manila. Sometime in 1939, the central KMT headquarters in China sent Wang Cheng-t'ing, a member of the Central Executive Committee, to Manila to establish a San-Min-Chu-I Youth Corps chapter to conduct donation and bond campaigns. ${ }^{129}$ Apparently, Wang was not successful in establishing the Youth Corps; it was not founded until shortly before the outbreak of the Pacific War. Consequently, the central KMT headquarters found it necessary to return Ong Chuan-sien to Manila, where he arrived in late January, 1940. Ong, highly respected by his fellow Chinese in Manila, was able there to organize a Chung Shan Hsüeh She (Sun Yat-sen's Society), which he directed. The leaders of the Society were "several prominent businessmen and a handful of intellectuals, most of whom were teachers of Chiang Kai-shek High [School]," and they were believed to have "strong pro-CC clique leaning." 130

Meanwhile, friction arose between the junior and senior factions of the Party, apparently over difference in anti-Japanese strategy, for it was in the spring of 1940 that assaults on Chinese merchants and fights between factions broke out in Manila. It was clear that the junior faction, including Sy Yat-sien, Cua Chün-ti, and Tseng T'ing-chuan, wanted a more aggressive and militant policy than did the elder party leaders like Sai Kuo-ch'üan and Tan Unliong. For some months, the younger leaders had their way, as Japanese were intimidated-even assaulted. Not much is known about the junior faction's reasons for challenging the party elders and jeopardizing Chinese relations with 
the Philippine authorities (which had been deteriorating for some time) by their militancy. The younger leaders appeared to be impatient to get boycott results, but the older leaders had a stake in business, which would suffer should the boycott be intensified. That may be the reason for the factionalism that contributed to the disintegration of discipline and to the rash of violence. The Japanese Consul General, Yoshida Tan'ichirō, was so deeply troubled by the turn of events that he asked Manila authorities to take stringent measures to suppress Chinese anti-Japanese activities and to apprehend persons responsible for violence. At the same time he presented a list of organizations that had been instigating illegal activities, including the Chinese Commercial News and the Fookien Times. ${ }^{131}$

The in-fighting continued throughout summer and fall. In October, Wu T'ieh-ch'eng arrived in Manila and offered to mediate between the two groups, whose struggle was contributing to the demoralization of the Chinese National Salvation Movement by endangering party unity. His intercession, however, did not close the gulf that separated the two factions, and the rivalry remained. ${ }^{\mathbf{1 3 2}}$

In 1941, the Party faced another factional struggle, which split it between local KMT leaders and San-Min-Chu-I Youth Corps leaders. According to Chen, the central KMT government had sent Lin Tsomei to the Philippines "shortly before the war" to organize the Youth Corps, which immediately quarreled with the local KMT headquarters about discipline. The Youth Corps refused to submit to the discipline of the local Party, claiming that it had been set up "by the order of the central government." On the other hand, the local Party headquarters insisted that the Youth Corps submit since "the Kuomintang headquarters in Manila was the supreme party organ in the Chinese colony, and it had power to put all other Kuomintang oganizations under its administrative control." ${ }^{133}$ This struggle appears to have been a rivalry between the Chungking-KMT-oriented leaders such as Lin Tso-mei, Sy Yat-sien, Cua Chün-ti, C. C. Fang, and Hsieh Teh-ch'ao, on the one hand, and the Manila KMT-business-oriented leaders such as Sai Kuo-ch'üan and Tan Unliong, on the other. Sy, Cua, Fang, and Hsieh were allies and had been close since 1940, when they spent several months in Chungking receiving political training. They were said to have had friendly relations with top government of- 
ficials. ${ }^{134}$ Therefore, the inference is that the four leaders and Lin Tso-mei were Chungking-oriented. On the other hand, Sai Kuo-ch'üan and Tan Unliong were businessmen and KMT members with strong ties in Manila. They had received no indoctrination in Party ideology and no military and political training in Chungking as their rivals had. $^{135}$

Another tension was between the KMT and business circles, possibly as a result of the boycott and of strained relations between Japan and the United States since the beginning of 1941, creating ill feelings between Ong Chuan-sien and Alfonso Sycip Hsueh Fen-shih. Alfonso Sycip, president of the Manila Chinese Chamber of Commerce and vice-president of the PREC, was one of the members in the Chamber of Commerce group who was aware of the difficulties involved in a boycott of Japanese products. It was reported that Alfonso Sycip tried to discourage the Chinese business group from the boycott in February, 1938, knowing well the economic consequences of such boycotting. ${ }^{136}$ Although he had supported the National Salvation Movement from the beginning, he did not approve of a boycott. As the boycott entered its second year, it began to hurt the Chinese economic position as much as it hurt Japanese trade. Aware of the difficulty, Alfonso Sycip spoke out on the subject to Chinese businessmen at the meeting of the Hua-ch'iao Business Recovery Committee. "The Chinese must regain their primary mission [of being businessmen]," he counseled, "and must not be excessively indulged in military and political affairs."137 On another occasion, he accused Ong Chuan-sien of having exploited the Chinese in the interests of the KMT by "politicizing" the National Salvation Movement beyond its proper role. Alfonso Sycip, as president of the Chamber of Commerce and vice president of the PREC, seemed to be a frustrated man in February, 1941, when he decided to retire from the presidency of the Chamber of Commerce. He pleaded that he was no longer capable of carrying out the heavy burden of office and of protecting the welfare of the Chinese community in general and the business community in particular. Only after receiving a flood of mail from various associations throughout the Philippine Islands, did he retract his resignation and agree to stay on for one more term. ${ }^{138}$

There was division not only within the KMT hierarchy, between 
the Chungking-oriented KMT faction and the Manila-oriented faction, and between the KMT and the business circles, but also between the KMT and the Communists. As I pointed out in Chapter I, there was some evidence of Communist infiltration of the National Salvation Movement in the Philippines. A left-wing group grew rapidly, particularly after the outbreak of the Sino-Japanese hostilities. ${ }^{139}$ Parallel with the development of this left-wing organization was the Philippine Islands Communist Party's interest in the Chinese National Salvation Movement. By the beginning of 1938, the Kuomintang-Communist alliance against Japan was "in full force" in the Philippine Islands. ${ }^{140}$ The League for the Defense of Democracy, the Friends of the Soviet, and the Civil Liberties Union formed the Congress for Peace and Collective Security. Its aim was to organize an anti-Japanese boycott, and it cooperated with the Chinese community to do so. ${ }^{141}$ This cooperation culminated in October, 1938, at the Third Congress of the Communist Party. The united front against Japan was quite in evidence. Besides an address by a Kuomintang representative and the reading of greetings from Mme. Chiang Kai-shek, there were repeated references to the "gallant resistance of the Chinese against Japan."142 Following the Congress, the Party urged the Philippine government to boycott Japanese goods. ${ }^{143}$ Reporting the extent of Communist involvement in the Chinese anti-Japanese movement, acting Consul General Kihara informed his home office in May, 1939, that Communists and Chinese had been portraying Japan to the Filipinos as "a nation attempting to invade the Islands and to destroy democracy." The purpose of this Communist-Chinese community campaign, Kihara concluded, was to create favorable public opinion for anti-Japanese groups in order to offset President Queson's rather friendly policy toward Japan. ${ }^{\mathbf{1 4 4}}$

Kihara's assessment and McLane's opinions of the KMT-Communist-Chinese community collaboration against Japan are correct insofar as they describe the surface phenomenon of the united action. It is common knowledge that the KMT-Communist united front was not a happy marriage between the two antagonistic parties, and it created more discord than harmony in South Seas Chinese communities. The Philippines were not spared the impact of the KMT-Communist struggle which existed beneath the cover of collaboration. The struggle between the KMT and the Communists erupted at the time 
of the New Fourth Army incident in January, 1941. The PhilippineChinese community felt its impact. For instance, the Davao Chinese Resist-the-Enemy Committee split into two factions. The chairman of the Committee supported the Communist New Fourth Army and sent a telegram to Chungking pleading for the release of the captured Communist General Yeh T'ing; the vice-chairman sent a cablegram to the Chinese wartime capital demanding his immediate execution. By adhering to their respective viewpoints, they unwittingly divided the Committee and the Davao Chinese community. The division weakened considerably the effectiveness of the organization's antiJapanese operation. Signs of division were reported in Chinese associations throughout the Philippine Islands. ${ }^{145}$ No doubt many of the Chinese who expressed opinions about the incident had no ideological commitment to either the KMT or the Communists, but they were compelled to speak out because of concern for China.

From the preceding account, it is apparent that after the fall of 1938, the Chinese National Salvation Movement in the Philippines encountered many difficulties. As the boycott continued, the initial enthusiasm naturally wore off, business circles felt the economic impact, and both Filipino and Chinese communities resented the inconveniences. Business leaders no doubt felt pressure both from within and without their circles. On one hand, the Philippine authorities insisted that they maintain law and order; on the other, KMT members, intellectuals, and journalists, who had no particular economic stake in a boycott, insisted that they carry on anti-Japanese activities. Under these trying circumstances, tensions developed within the triangle of the KMT, the KMT government, and the Chamber of Commerce. Relations deteriorated, particularly when the KMT attempted to wrest the control of the boycott campaign from the Chamber of Commerce. Nevertheless the Chamber of Commerce, the main medium of propaganda from China, did not yield to the KMT's attempts to control it.

The difficulty of the Filipino-Chinese movement was compounded by something beyond its control-diplomatic tension between Japan and the United States. The Chinese in the Philippines were acutely aware of the precarious position of the Islands in the event of a Japanese-American war; they admitted their deep concern over the impending war between Japan and the United States. ${ }^{146}$ Conse- 
quently, reports from Manila in March, 1941, described the uncertainty of the Chinese. Many of them were so obsessed by the fear of war that they scarcely had time for the boycott and other anti-Japanese activities. As a result, there was no anti-Japanese propaganda; the special contribution drive organized by the youths under the auspices of the PREC had ended, though the regular monthly giving campaign continued; and boycott inspectors and enforcement agents had disappeared from the streets. ${ }^{147}$ The worsening Japan-U.S. relations compelled local KMT agents to deliberate on measures to take should war come to the Islands. Their attention is believed to have been focused on what to do if Japanese troops should occupy the Islands, what to do with the enemy resistance committee, and how to dispose of the property and assets of the Chinese. It appears that KMT agents themselves did not agree on the course to take. One group advocated resisting Japan either by joining the American-Filipino troops or by fighting under the command of a Chinese leader to be sent from Chungking. The other group suggested limiting anti-Japanese activities in order not to provoke the Japanese, since the Japanese occupation of the colony would mean life or death to Chinese who had been active in the National Salvation Movement sponsored by enemy resistance committees. ${ }^{148}$ Reflecting the growing anxiety of the Chinese community, in late February, the Chungking government sent instructions, together with a document, Ten Principles for the Protection of the Chinese in Emergency, to the consul general in Manila. For the next few days, Chinese leaders of the community, the Party, and the Consulate closeted themselves for a series of conferences. There is no report of what happened at the meetings. Statements issued after Consul-General Yang met with the Philippine authorities and High Commissioner Sayre suggest that most of the Chinese leaders had agreed to give priority to safeguarding the lives of the Chinese, who would be evacuated to a safe area, and to cooperating with authorities to protect non-combatants. ${ }^{149}$ Presumably, most government officials and community-business leaders thought it unwise to resist the Japanese. If those decisions reflected the state of mind of the Chinese leaders, we can understand why consulate officials and business-community leaders chose to remain in Manila after the Japanese invasion, allowing themselves to be arrested, while die-hard KMT leaders and Com- 
munists went to the mountains in order to wage a guerrilla war against the invaders. ${ }^{150}$

It must be assumed, then, that Chinese anxiety over the possibility of war contributed to the slackening of the boycott in 1941. Strained relations among the community-business circles, the Consulate, and the Party curtailed the effectiveness of the National Salvation Movement. Nevertheless, it does not mean that all these groups were working to protect only their own interests; they were still loyal to the objectives of the National Salvation Movement. Many community-business leaders, even after they were released by the Kempeitai in 1943, avoided, to the best of their ability, having anything to do with the Japanese military administration. As a result, the Japanese authorities were unable to find anyone with stature willing to collaborate. ${ }^{151}$

\section{Thailand}

The history of the Chinese anti-Japanese drive in Thailand after 1938 is as much a story of KMT-Communist-directed terrorism as it is a chronicle of the government's repression of the Chinese. Throughout 1939 and 1940, the Thai police worked like bloodhounds to track down and expose illicit Chinese societies. The searches were sometimes accompanied by discriminatory acts designed to undermine the Chinese position. ${ }^{152}$

From what can be deduced from available official and semi-official intelligence reports, ${ }^{153}$ the KMT and the Communists were more active in anti-Japanese activity in Thailand than in any other place except British Malaya. The KMT was believed to be operating through legal and semi-secret organizations such as the Office of Commercial Representative of the Chinese government; the Chinese Chamber of Commerce; the Thai-Chinese Relief Fund-Raising Association (TCRFRA), which had been created as a front within the Chamber of Commerce; and the Thailand Office of the KMT, which had power over the Resist-the-Enemy National Salvation Association. Ch'en Shou-ming, a KMT representative of commercial affairs, a member of the KMT Political Council (Ts'an-cheng-yüan), and former chairman of the Chinese Chamber of Commerce in Bangkok, was an influential anti-Japanese leader. He was also the principal stockholder in three dailies, one of which was the Hua-ch'iao Jih Pao. This news- 
paper had consistently supported Chiang Kai-shek; and its editor, Chang Ch'ih-feng, was a long-time protege of Ch'en Shou-ming, a member of the KMT, and the principal of the Huang Hun School, which was closed because of its anti-Japanese activity. After Hsiao Fo-Cheng's retirement, in 1938, Yi Kuang-yen became chairman of the Chamber of Commerce and served until he was assassinated in November, 1939. Together with Ch'en Shou-ming, chairman of the TCRFRA, Yi Kuang-yen supported the National Salvation Movement, though some reservation about his true political coloration existed. The KMT, at the peak of its strength, had 200,000 members; but the number dwindled over the years, particularly after the military took over the reins of the Thai government. In 1939, membership was estimated at about 30,000. The strength of the Party had been sapped by a perennial split between the progressive wing and the orthodox wing and by a series of police raids in which its leaders were arrested for anti-Japanese activities. Although the central Party and its leaders suffered setbacks, its branch offices, chapters, and cells throughout the Kingdom were well-organized. The KMT not only had control over its branch offices of the Resist-the-Enemy National Salvation Association but also had jurisdictional authority over the Chinese schools.

The list of organizations which the Chinese Communist Party controlled through its Hong Kong bureau, headed by Liao Ch'eng-chih, is long. Communist followers were found among intellectuals, students, the young, refugees, and hoodlums whose primary mission was to advocate boycotting and to intimidate recalcitrant Chinese merchants or to perform acts of terrorism including murder. Communists were known to be dominant in a number of organizations. The Thailand Hua-ch'iao League for the Anti-Japanese National Salvation Movement was an association organized by school teachers and led by Kuo T'ien, a teacher at Chung-hua Middle School and the chief editorial writer of the Hua Sheng Jih Pao. The Hot Blood Youth Corps for Resist-the-Enemy and National Salvation and the Eradication of Traitors, the Thailand Youth League for Anti-Japanese National Salvation, and the Iron Blood Youth Anti-Japanese Association were all devoted to terrorism and assassination. Liu Pi-ch'uan, Yang Sung, Ch'en Ho-k'un, Wang Tso-sheng, Ts'ai Chih-fang, Hsü Ching, Yu 
Shan-tung, and Lo Jung-kuang were officers of these groups. The Nanyang Hua-ch'iao Youth League was known to include more than one hundred assassins, who were credited with having murdered 35 persons and injured 117 by the end of 1939. The Hua-ch'iao RescueSquad-for-Bangkok Guerrilla Committee and the Thailand Hua-ch'iao League for Anti-Japanese Executive Committee were headed by Ch'en Jung-tzu, whom the Eighth Route Army had sent to Thailand. The Thailand Hua-ch'iao League for Anti-Japanese Executive Committee, an amalgamation of all anti-Japanese groups, had been organized at the request of Consul General Kao of Singapore when he visited Bangkok. The Laborers' Resist-the-Enemy and National Salvation Corps and the Thailand Labor-Comrade National Salvation Association were largely proletarian. And finally, the Thailand Hua-ch'iao Women's Anti-Japanese National Salvation Association was made up of prostitutes, waitresses, and bar hostesses. Leftist intellectuals and youths provided leadership for each of these organizations, drawing financial support from the Chinese Chamber of Commerce, the Rice Mill Association, and the Rice Merchants' Association. Contributions and fines these Communist groups collected were not channelled to the coffers of the Chiang Kai-shek government but siphoned through Ubon and Khu Khan in the northeast to the Ch'̈̈an Min Jih Pao in Saigon and sent from there to the Eighth Route Army in Kwangtung province.

To what extent the KMT and Communists united in the National Salvation Movement in Thailand can never be determined. The fact that the consul-general succeeded in uniting all associations is indicative of KMT-Communist unity, but how much they cooperated in policy execution is something else. For instance, Communist intellectual leaders proposed, from time to time, to combine their antiJapanese campaign with that of the KMT-sponsored Resist-the-Enemy National Salvation Movement, but the Association repeatedly rejected the proposal for unspecified reasons. With or without the united front policy, the anti-Japanese organization was the strongest in the Kingdom. With this background, let us look at the record of the Thailand Chinese National Salvation drive after July, 1938, till the outbreak of the Pacific War in December, 1941.

The boycott to which the Thai-Chinese had resorted to manifest 
their support of their fatherland had already proved, according to Skinner, "extremely effective" in 1937 and early $1938 .{ }^{154}$ It was perhaps this rising Chinese nationalist fervor that provided additional fuel to the prejudicial policy of the Thai government, despite its denial of anti-Sinicism. As already pointed out, the Thai government, in the wake of Chinese national consciousness during the Sino-Japanese war, had been deliberately curtailing Chinese economic strength under the program of economic Thai-ification; it is therefore difficult to distinguish the Thai government's anti-Chinese policy on the grounds of Thai-ification from its anti-Chinese policy on the grounds of their antiJapanese movement. From the Thai government's point of view, Chinese political action against Japan (to which Luang Phibun Songkhram had been drawn closer) was a convenient excuse to suppress the Chinese, and the suppression served a dual purpose. It accented a new Thai nationalism, and it placated the Japanese.

In spite of numerous arrests of anti-Japanese leaders in the early months of 1938, the Chinese National Salvation Movement did not recoil but bounced back with fresh vigor. "In October, 1938, the militantly anti-Japanese cause was further strengthened by the establishment of the Chung-kuo Jih-pao ...," Skinner said, and strong men of various anti-Japanese groups took the law into their own hands. "Bombings, shootings, and kidnappings occurred with increasing frequency after the fall of 1938." ${ }^{155}$ Then in late January, 1939, news of police raids on the headquarters of illicit Chinese secret societies shattered the holiday mood of the Chinese, ready to greet their New Year. The raids exposed two centers of the Resist-the-Enemy National Salvation Association, and police seized bundles of anti-Japanese circulars. One of the arrested members was reported to have confessed that he had bombed a Chinese store selling Japanese merchandise. ${ }^{\mathbf{1 5 6}}$ In 1939, the Bangkok government also curtailed both open and clandestine Chinese financial aid drives on the grounds that "any relief for a country at war is ipso facto for war purposes." Scores of Chinese leaders and businessmen in Bangkok and Chiengmai were arrested when police discovered that they were collecting contributions and selling bonds. ${ }^{157}$

Notwithstanding the blows the Chinese had sustained, in addition to the disheartening news of the fall of Ch'aochow and Swatow in June, ${ }^{158}$ the boycott showed no sign of faltering; in fact it gained 
strength because of a rigorous press campaign which the Chungking government conducted in China and Thailand. The Chung Hua Min Pao, on July 14, 1939, urged the Chinese not to remit money to Japanese-occupied Ch'aochow and Swatow, because every penny sent to those cities would enable the enemy to acquire foreign capital. "This is," the paper declared, "an act supporting the enemy." in early July, all local Chinese newspapers denounced rumors circulating in Bangkok that the Chinese troops had "retreated without exchanging resistance" when the Japanese troops landed at Swatow. ${ }^{\mathbf{1 6 0}}$

In the third week of July, the government determined to contain the Chinese political action and murderous assaults and raided the San-min she, which served as the office of the KMT branch in Thailand and of the KMT San-min Youth Club. Not only were the men in charge of the organization apprehended, but several wagonloads of documents, together with a party membership list, were confiscated. At the same time, Wu Pi-yen, a member of the Standing Committee of the KMT in Thailand, was arrested. The leaders were deported. ${ }^{\mathbf{1 6 1}}$ That police raid was the beginning of the government's containment program, which extended through August. During these months, newspaper offices, schools, printing plants, banks, a remitting office, Chinese Association headquarters, and the Chamber of Commerce were searched. Evidence was gathered to show that these organizations had been engaging in illegal activities. Sixteen schools, including three which were centers of Communist activities, were closed for violating the educational ordinance. ${ }^{162}$ All but one newspaper, the Chung Yüan Pao, were shut down permanently on grounds of "instigating the anti-Japanese boycott and anti-Japanese movement as well as obstructing peace."163 The Overseas Chinese Bank and the Kwangtung Bank were searched and found to be holding "disguised deposits ... presumably destined for China's war chest."164 The manager and the assistant manager of each bank were detained. In August, a remitting office suspected of having remitted money to China was investigated. In the grand climax of this series of raids, the Chinese Chamber of Commerce and its leading members were searched and questioned on August 12, and its headquarters was temporarily closed. ${ }^{165}$

The revelation of the extent of both open and secret Chinese politi- 
cal activities in conducting the anti-Japanese boycott, raising money for the war, ${ }^{166}$ and directing a number of terrorist acts drew quick, scathing criticism from the Thai public. Denouncing the terrorism and wanton murders which had become "almost commonplace" by late July, the Siam Chronicle stated that "the gang operating in Bangkok do not seem to follow the ideals and rituals associated with the ancient secret societies in China. They are mere racketeers and criminals and though some of them claim to be 'patriotic,' we are afraid that their campaign in this country cannot be justified on that basis."

The confusion that followed the sweeping arrests in July and August had hardly subsided when Yi Kuang-yen was assassinated on November 21, shortly after his return from Chungking. ${ }^{168}$ Why he -reputedly a supporter of the National Salvation Movement-was murdered was never satisfactorily explained. Kenneth P. Landon says that one of the two assassins confessed to the police, saying that his father had been fatally wounded by a member of the Resist-the-Enemy National Salvation Association and that Yi was head of the organization. ${ }^{169}$ This account interprets the crime as merely the result of one man's attempt to avenge his father's death. One Japanese intelligence source reported that contrary to public opinion, Yi was not really antiJapanese. This report, originating from the Mitsui's Siam Research Office, described him as having "the closest business relations with Japan." He was, the report said, "dragged into the anti-Japanese activity because of his position as president of the Chamber of Commerce. ... He should be marked as the most approachable person to Japan." Moreover, he was believed to have gone to Hanoi and met with a member of the Wang Ching-wei faction in the early months of 1939. ${ }^{170}$ There is little more to substantiate this report of Yi's political orientation toward the Wang faction. ${ }^{171}$ It must be remembered that the Mitsui was the largest Japanese trading corporation doing business with Thailand; that Chinese like $\mathrm{Yi}$ were important to its business; that the company's research office in Bangkok scrutinized the commercial and political activities of Chinese leaders with whom the Mitsui dealt; and that the research office worked hand-in-glove with the Japanese military intelligence establishment, as did similar Japanese organizations in Southeast Asia. If the Mitsui report can be trusted, the validity of the published version of the assassination motives 
can be challenged. Significantly, few Japanese sources identified Yi as a leader of the anti-Japanese movement; most of them listed him merely as president of the Chamber of Commerce.

The July-August calamity and the assassination of Yi Kuang-yen considerably weakened the Chinese National Salvation Movement and brought its most effective phase to an end. ${ }^{172}$ Some KMT members went into hiding up-country; others fled the capital and made their way overland to Annam, British Malaya, and Yunnan, China; and still others, including newspaper reporters and teachers and a few merchants, slipped out of the country to Kunming. ${ }^{173}$ It should be pointed out that most of those arrested in the summer police raids were KMT members; few were Communists. The decrease in terrorism and assassination following the summer arrests, however, was indicative of the disintegration, for the time being, of Communistorganized crime in Thailand. ${ }^{174}$ Nevertheless, the Thais publicly condemned self-styled "patriotic" Chinese when violence occurred. ${ }^{\mathbf{1 7 5}}$ Thai authorities continued to maintain strict surveillance on Chinese political activities. When Chinese anti-Japanese activities disturbed the peace in January and February, 1940, there was another wave of arrests. ${ }^{176}$

Though nearly demoralized by the relentless police action since the summer of 1939, the Chinese "were by no means completely cowed . . . , and activities to help the cause of China and resist the Japanese advance continued." 177 When, after 1939, it became increasingly difficult to conduct any form of the campaign in the open, the Chinese National Salvation Movement went underground. The relief-fund-raising associations and other money-collecting agencies continued to receive contributions and send them secretly to China by way of Hong Kong, Malaya, and Hanoi. Chinese hospitals in Bangkok secretly trained nurses to serve with the Nationalist army in China, but sometime in 1940, the Thai authorities discovered and banned the training program and deported two hospital officials. ${ }^{178}$

In the absence of normal diplomatic relations between Bangkok and Chungking, the suppression and the discriminatory policy of the Thai government created a very serious problem for the Chinese. To continue the National Salvation Movement would provide the Thai government a convenient excuse to destroy Chinese business in the 
interests of the economic Thai-ification program. It seems certain that the Chinese community-business leaders pondered the question in January, 1940. There was a change of policy in respect to the National Salvation Movement and to the Thai government, prompted, perhaps, by the Phibun government's disregard of the Chiang government's plea to establish diplomatic relations. Chang Lan-ch'en, the new president of the Chinese Chamber of Commerce, appeared to be the leading figure in favor of the new policy. The first sign of the change was detected in February, 1940, when Chinese leaders declined to accept the NCRGA's invitation to participate in sending comfort missions to China. ${ }^{179}$ They were the only Chinese to disassociate themselves from the NCRGA-sponsored program, apparently because they feared the response of the Phibun government. The second indication of the shift in policy was a definite decline in violence. After February there occurred no serious incidents like those that had aroused indignation among the Thai public in the past year. The effort to prevent violence may be viewed as part of the policy of restraint that followed the attack on Chinese schools, an attack which occurred because these schools were not teaching the Thai language. Further agitation in the politically oriented National Salvation Movement would increase Chinese vulnerability. Refraining from violence and political activities might not—and did not-stop Phibun's issuing discriminatory decrees, but the Chinese needed every bit of goodwill they could get from the government.

The third unmistakable sign of the new policy adopted by Chinese business leaders was their attempt to establish friendly relations with Thai government officials. Beginning in July, led by Chang Lan-ch'en, they tried to cultivate the friendship of the Thai elite, hoping that the new approach would soothe the ruffled feelings of the high officials. On a number of occasions throughout the summer and fall, Chang urged his fellow businessmen to invest in Thai industries and to support the Thai government's claim to the territory lost to French Indochina. ${ }^{180}$ This accommodation policy was successful only as long as the Thai government found it convenient and expedient, because that government was ready to sacrifice the Chinese for a greater stakeJapan's friendship. Thailand's foreign policy was committed to the winning side of the Sino-Japanese war, and no money or verbal sup- 
port of the Chinese could buy it back. Acting as mediator, Japan enabled Thailand to regain the lost territory from French Indochina in January, 1941. After the settlement of this territorial dispute, Thailand was drawn even closer to Japan. The rekindling of the Thai government's discriminatory policy in May, 1941, ${ }^{181}$ was another example of the anti-Sinicism of the Phibun government.

The Chinese leaders' policy toward the NCRGA was consistent with their decision to endure despite their helplessness and their suffering. When they received the invitation to attend the second NCRGA assembly in Singapore in March, the TCRFRA decided not to reply. ${ }^{182}$ A Chinese source, however, noted that representatives of several Chinese associations in Thailand attended the conference. They joined other delegates, it says, to support Chiang Kai-shek and his policy of resistance and reconstruction, declaring that the Nanyang Hua-ch'iao would "not compromise or change" and would "remain firm." ${ }^{183}$ It is inconceivable that these Thai-Chinese delegates represented the TCRFRA, which maintained the policy of restraint. It ignored the NCRGA invitation, it seems, to avoid unnecessary complications with the Thai government. The argument that the TCRFRA secretly sent these representatives to the conference without replying to the invitation is not plausible because the Chinese account just quoted was published on April 1, 1941, less than four weeks after the meeting. Thai officials would certainly have taken note of it and would have held Chinese leaders accountable. It is recalled that NCRGA officials took special measures to delete names of Thai delegates to the first meeting of the NCRGA in Singapore in October, 1938, obviously to protect the delegates and their sponsoring associations. In the absence of information about these representatives-who they were and which organizations they represented - the only explanation one can make for their presence at the second meeting is that they attended of their own accord, probably without consent of the TCRFRA and certainly without permission of the Thai government, for it is unlikely that the Bangkok government would have granted such a permit in the light of its policy toward the National Salvation Movement. ${ }^{184}$

By the time war came to Southeast Asia in December, 1941, the ranks of the Chinese leaders had been seriously depleted through arrest, deportation, and flight upcountry or to China. KMT- and Com- 
munist-led illegal activities had been driven underground, and antiJapanese activities had practically ceased to be an organized drive. The TCRFRA, the main body of the National Salvation Movement, was no longer an active organization capable of promoting the campaign to support China. Circumstances forced Chinese business-community leaders, led by Chang Lan-ch'en, to weigh the situation, squeezed as they were by the Thai government's discriminatory policy and by Japan's southward march. In an article about the problems of the Chinese Chamber of Commerce filed in Bangkok, a correspondent of the respected newspaper Asahi reported that in early April, 1941, the Chamber had resolved to purge itself of anti-Japanese sentiments in the hope of hastening a peaceful settlement of the Sino-Japanese war. ${ }^{185}$ Admittedly the report was a bit too optimistic, but it seemed to convey the mood of leading Chinese within the business circles. On the other hand, die-hard KMT underground anti-Japanese activities persisted, as evidenced by the arrival of "a large number of Chinese fifth columnists" in Thailand in late March. ${ }^{186}$ Because war clouds hung heavily over Thailand, the country had become a center of intelligence gathering and espionage for Japan, the United States, Britain, China, and even Germany. The Japanese Army and Navy had mobilized their resources in order to collect information on which to base invasion plans and had stepped up their effort in order to acquire strategic materials. The Mitsui's office, at the direction of the military, bought embargoed Malayan tin and rubber through Chinese merchants in Bangkok. Chungking government agents likewise were busy collecting information on the movements of the Japanese. ${ }^{187}$ Some Chinese helped the Japanese military plan the invasion; others risked their lives in cloak-and-dagger operations or showed hostility toward the Japanese. ${ }^{188}$ But most of the Chinese, even some business leaders like Chang Lan-ch'en, were deeply concernd about the uncertain future. As one Japanese naval intelligence officer in charge of Chinese affairs, attached to the Japanese Embassy in Bangkok, observed, the average Chinese remained calm, holding his breath and maintaining circumspection on the eve of the Japanese invasion, and the Mitsui and the Mitsubishi were doing business with Chinese as usual. ${ }^{189}$

It is obvious that the Thai-Chinese struggled to support the antiJapanese movement even when the odds were decisively against them, 
enduring molestations which amounted to a systematic persecution. KMT influence and its organizational activity were substantial until the Thai government crushed them, and there was every reason to believe that the Communists were responsible for the militancy of the anti-Japanese campaign. Likewise, the National Salvation Movement of the Chinese business-community group and its affiliates was a strongly organized campaign until the end of 1939. Beginning in 1940, however, its effectiveness decreased considerably, and its leaders sought to make peace with the Thai authorities, repudiating what might be regarded as the political aspect of NCRGA activities and deemphasizing overt anti-Japanese activities. On the eve of the Pacific War, most of the Thai-Chinese, like the Philippine-Chinese, were frightened and just waited, hoping that the Japanese military would let them alone. One should not be too quick to assert that the behavior of the Thai-Chinese proved that they were less patriotic than other South Seas Chinese. Rather, the price they paid for the National Salvation Movement should be emphasized. By the end of 1939, 10,000 Chinese suspected of illegal activity had been interrogated, and 3,000 had been arrested. ${ }^{190}$ By the time the war broke out, Thai authorities had deported several thousand as undesirable aliens on the grounds of anti-Japanese activities. ${ }^{191}$ Even excluding those who were bona-fide terrorists, the attrition was high, indicating in part the intensity of the National Salvation Movement. Furthermore, the efficacy of arrests and deportations in controlling the Chinese anti-Japanese drive refutes the Japanese charge that Thai policemen and high government officials were sympathetic toward the Chinese because they themselves were of Chinese extraction; ${ }^{192}$ on the contrary, it was these high officials who were most anti-Chinese, just as Nazi-Jews were more anti-Semitic than their Aryan colleagues. ${ }^{193}$

\section{French Indochina and Burma}

The KMT attached great importance to French Indochina and to the Chinese there because the country was contiguous to south China and was a supply base from which China acquired essential materiel. Aware of the importance of French Indochina and its Chinese residents to the national defense system of the Chiang Kai-shek government, the KMT appointed Hsiao Chi-shan, a candidate member of 
the KMT Central Executive Committee, to head the Hanoi Office of the KMT Overseas Chinese Affairs Commission. His principal function was to coordinate and unify activities of the Cantonese and Fukienese in the best interests of the Chinese government. ${ }^{194}$ On the other hand, the Annam branch of the KMT established boycott headquarters at Hanoi and Saigon-Cholon, each directed by a consul responsible for boycott and contribution drive policies and the sale of stocks for the industrial development project in southwest China. These national salvation groups, under the guidance of the local KMT apparatus, also formed voluntary youth corps for home front service. Youngsters were given a six-month training course in mechanics and sent to the Hanoi-Yunnan (Kunming) Road as auto repairmen and drivers. The KMT machinery likewise made an extraordinary effort to stir up the patriotism of the Chinese by establishing numerous mass communication groups. ${ }^{195}$ In Cholon, the Chinese quarter of Saigon, a Voluntary Association for National Salvation, an Association for the Promotion of Chinese Culture, and other Hua-ch'iao associations organized schools and inculcated anti-Japanese ideology in the Chinese masses. Favorable and stirring news from Chungking was disseminated through facilities of the KMT Consulate General at Hanoi and through wall newspapers provided by the Hua-ch'iao Middle School. Finally, branch offices of the Chinese Council for Foreign Relations in Hanoi and Saigon sponsored cultural activities designed to arouse patriotic passion.

It is difficult to estimate the degree to which the KMT's anti-Japanese drive roused the national consciousness of the Chinese. Wang Ching-wei's defection from Chiang Kai-shek and his subsequent arrival in Hanoi in December, 1938, caused great consternation. ${ }^{196}$ To counteract the effect of Wang's dramatic escape from Chungking, KMT agents in Indochina mobilized their resources to generate antiWang and anti-Japanese feelings, culminating on March 21, 1939, in an assassination attempt on Wang Ching-wei in which his close associate, Tseng Chung-ming, was killed by KMT assassins' bullets. A sharp decline in Japanese exports to French Indochina in January and February was indicative of KMT propaganda and of the general sentiment of the Chinese toward Wang Ching-wei and the Japanese. That boycotting continued throughout 1939 is evidenced by import figures 
lower than those of $1938 .{ }^{197}$ Chinese interest in helping China was strong as late as February, 1940, when Chinese national salvation associations participated in the NCRGA-sponsored program to send comfort missions to China. But in French Indochina, as elsewhere in Southeast Asia, there were recalcitrant Chinese merchants who tried to sell Japanese articles by changing their labels. Others complained that increasing demands for contributions were over-taxing their financial resources. ${ }^{198}$ For instance, in the winter of 1938-1939, many Chinese were reluctant to buy Fukienese government bonds during the subscription campaign headed by Chang Chen-fan, a leading rice merchant in Saigon-Cholon. As a result, Chinese in the French colony failed to meet their quota of 150,000 yuan. By early spring, 1941, enthusiasm for contributions had sunk so low that the Chungking government reportedly sent special agents to Saigon to open a campaign to register each person's donations. ${ }^{199}$ Furthermore, the Chinese had to gauge carefully the attitude and sentiment of the French colonial authorities and the Vietnamese to determine how far they could go without provoking an adverse response. There were causes for the Chinese concern; the French authorities were apprehensive of the economic crisis that the Chinese boycott was creating and of the effect of the anti-Japanese movement on Vietnamese nationalism, and the natives were unhappy about the soaring prices of commodities in the wake of the boycott and the influx of refugees from China. ${ }^{200}$ Too, Japan's southward penetration and her increasing pressure upon the French colonial government after the fall of France in June, 1940, were not without effect. The acquiescence of the French Vichy government to a Japanese demand for stationing a Japanese inspection team along the Indochina-China border (June), Japan's march into the North (September) and the consolidation of her position in the area through Thai-French Indochinese border mediation (January, 1941), and finally her invasion of the South (July) made the Chinese feel the presence of the Japanese military might. Shortly after the Japanese military had completed the deployment in September, 1940, Governor General Decoux, a Vichy appointee, was obliged to suppress the Chinese anti-Japanese campaign; consequently not only were Chinese unable to help transport strategic goods across the border to China, but the South Vietnam National Salvation Committee had to terminate 
the KMT-sponsored program of sending technicians and mechanics to China. Some KMT anti-Japanese drive coordinators fled the country. ${ }^{201}$ The presence of the Japanese military, along with the pressure of the French government, made life difficult for Chinese who had been active in the National Salvation Movement. For instance, a Japanese businessman has told of inviting Chu Chi-hsing, an influential Chamber of Commerce member whom he had met in business, to his home for a secret talk. He hoped to dissuade Chu from collaboration with the Chinese Consul. Chu, however, did not appear. When the Japanese visited him to find out what had happened, Chu apologized for his discourtesy and explained: "I was not able to visit because of close surveillance [maintained by anti-Japanese elements]. They will kill me if they find me visiting the Japanese. I do not wish to cooperate with Chungking or with Nanking since I have no particular liking or malice toward Chiang Kai-shek and Wang Ching-wei. I beg you not to get me involved in politics any further." At the conclusion of the conversation, Chu volunteered names of about a dozen persons who were prominent in the anti-Japanese campaign so that they could be persuaded to give up the campaign or could be arrested by the French authorities. ${ }^{202}$

From the preceding account, it is clear that the Chinese kept up a brisk campaign of anti-Japanese activities, except for monetary contributions until late 1940 or early 1941. A record shows a steady increase of trade with China and of transport on the Haiphong-HanoiKunming railroad until late 1940. The Chinese were thus responsible for keeping the Indochina-Yunnan railroad open and supplying vital goods to Chungking. The stationing of the Japanese troops in the North and the South made the National Salvation Movement even more difficult to carry on; there was some disagreement within the ranks, and some Chinese were afraid to commit themselves to the movement. Nevertheless, boycotting and anti-Japanese propaganda continued throughout the spring and summer of 1941, as evidenced by an eye-witness account and a press report. ${ }^{203}$

There is almost no information about Communist involvement in the Chinese National Salvation Movement, but, as in other countries in Southeast Asia, the Communists are believed to have cooperated with the KMT's anti-Japanese movement. Nguyen Ai Quoc (Ho Chi 
Minh) is known to have appeared in 1940 "in the Tongking as part of the special Chinese Communist mission sent there to train Chinese Nationalist guerrillas" against the Japanese. ${ }^{204}$ It is not surprising that Nguyen Ai Quoc joined KMT guerrillas who had been operating at Kunming in Yunnan province bordering French Indochina. Reporting the guerrilla operation in Yunnan, a Japanese military intelligence agent based at Hanoi told the Japanese Army Headquarters in Taiwan in early summer that twenty-two guerrillas had arrived in Hanoi from Kunming to launch anti-Japanese activity. ${ }^{205}$

Very little information is available for an assessment of the antiJapanese activities of the Chinese in Burma after October, 1938. Since the effect of the boycott upon Japanese trade in Burma was insignificant, the Chinese concentrated upon a contribution drive, organized jointly by the Burma Hua-ch'iao General Association for Relief, the Special Committee for Relief, the Red Cross Association, the Relief Association of Guilds, the League of Kwangtung Chinese for Relief, the Burma Branch for the Promotion of Bond Subscriptions, and the China Association for the Construction of Airplanes. ${ }^{206}$ According to the Hsing Tao Jih Pao, the Chinese gave 13 million yuan in the first three years of the Sino-Japanese war, in addition to 1.5 million yuan for airplanes, and 3 million yuan for trucks, clothes, drugs, and condolence funds for bereaved families. ${ }^{207}$ Though financially limited, the Chinese in Rangoon raised a quarter of a million yuan at a reception in honor of General Wu T'ieh-ch'eng when he arrived in the capital in early 1940 , and spontaneously gave 16,800 rupees in October, 1940, when the Burma Road was re-opened. ${ }^{208}$

Another instrument through which the Chungking government cultivated the goodwill of the Burmese was the China-Burma Cultural Association. Local Chinese were very active in the Association for the exchange of cultural programs and visits by dignitaries of both governments. ${ }^{209}$ Finally, KMT members were allegedly working with the British Criminal Intelligence Department in guiding the Chinese antiJapanese movement. ${ }^{210}$

The record and achievements of the Chinese National Salvation Movement from October, 1938, to the outbreak of the Pacific War show the Nanyang Hua-ch'iao's remarkable tenacity in supporting China's war for survival. For four years, they maintained anti-Japanese activi- 
ties, giving their moral and material support to the Chiang Kai-shek government at the crucial time, especially during the early phases of the Sino-Japanese war, when China had little help from outside. On the other hand, the boycott campaign, which had proved to be a rather effectual weapon until the end of 1939, became gradually weaker. By all indications, beginning in 1940, the boycott was not a threat to Japanese trade in Southeast Asia, more conspicuously in Thailand, the Dutch East Indies, and French Indochina than in Malaya and the Philippines. Internal factionalism between the KMT and the Communists and between the KMT and the business group was becoming noticeable. The factionalism was also indicative of the weariness of the Chinese in the National Salvation Movement, compounded by their fear of war. Furthermore, the presence of the Communists was disruptive because they competed with the Nationalists for influence. ${ }^{211}$

The increasingly important role of the KMT and the Communists in the National Salvation Movement was evident, but the results were not all positive. Increased KMT influence in the campaign caused some unhappy relations among leaders in Malaya and the Philippines. Its excessive meddling disenchanted some leaders, alienating them from the ranks, as in Malaya. The infiltration of the Communists no doubt added militancy to the anti-Japanese drive but provoked securityconscious local authorities to repress the National Salvation Movement, as evident in Thailand and Malaya.

Generally speaking, the Chinese National Salvation Movement faced more difficulties with local authorities after 1940, obviously as a result of pressure from Japan, whose military might made itself felt in Southeast Asian countries, especially Thailand, the Philippines, and French Indochina. Under such conditions, the protracted anti-Japanese National Salvation Movement produced strains. Some leaders began to vacillate, and their hard-pressed compatriots expressed, if not openly, their grievances against business disruption and the incessant demand for contributions. Notwithstanding, most of the Nanyang Chinese, whether KMTs, Communists, or non-partisans, were opposed to Japanese aggression in China and wanted to aid their fatherland. To achieve this immediate objective, the Hua-ch'iao, including the Communists (whose ultimate objective differed from that of the others), were ready to stand side by side with the KMT government, which had 
its revolutionary tradition deep in South China, the home of the Nanyang Hua-ch'iao.

It is no exaggeration to conclude that in 1937-1938, under the weight of financial strains, the Chiang Kai-shek government could have succumbed to a humiliating defeat without the monetary and material aid of the Chinese overseas. The material contribution of the Nanyang Chinese to sustaining the life of the gasping Chinese government was no small matter. This is the subject to be discussed in the next chapter. 


\section{Chapter III}

\section{Achievements of the Nanyang Chinese National Salvation Movement and its Economic Effectiveness}

\section{Return-Home Service Drive and Comfort Mission}

One of the major projects that the NCRGA sponsored for China's war effort was the dispatch of voluntary service corps of skilled laborers and technicians. They were sent to shuttle trucks carrying vital supplies on the Yunnan-Burma Road and the Yunnan-Hanoi-Haiphong Road and to serve in ambulance units and maintenance corps. ${ }^{1}$

The project was a response to resolutions adopted by the KMT Emergency Conference in Chungking shortly after the fall of Wuhan in 1938, and by the First Political Council in August of that year. These resolutions authorized the KMT to "train, in accordance to skills, overseas Chinese" who were "willing to die on the battle field for the defense of the fatherland" and to "tap the manpower resources of the Chinese abroad." The importance of the project loomed larger as the development of the hinterland and the maintenance of vital supply routes in the Southwest became urgent for the Chungking government. Consequently, the government appealed to the NCRGA to recruit technicians and mechanics, and in August, 1939, the Overseas Chinese Affairs Commission asked Nanyang Chinese Chambers of Commerce to compile a list of overseas Chinese professional personnel available for emergency. ${ }^{2}$

The total of recruits and volunteers for the military service, guerrilla corps, medical corps, civil engineering corps, and women's corps was small, and it is difficult to measure their contribution to China's war effort. ${ }^{3}$ The overseas volunteers, however, contributed significantly to the maintenance of the Yunnan-Burma Road and the YunnanHanoi-Haiphong Road, over which vital supplies were transported to Chungking, until the former was temporarily closed in July, 1940, and the latter completely in June of that year. It is estimated that a little over 3,000 volunteers, mostly from Malaya, Burma, and French Indochina, served on these arteries as drivers, mechanics, and repair- 
men during 1939.4 They enthusiastically volunteered for the service corps, and many patriotic tales illustrate their zeal. For example, a mechanic who earned two hundred yuan a month gave up his job to join the voluntary corps, which paid only thirty yuan. Another Chinese reportedly wrote to his mother that she should not pray for his safety but for the victory of his country and that he would not return home until the war was over. ${ }^{5}$ Nevertheless, by the end of 1939, the project had lost its appeal and glamour, and the enthusiasm with which it started had dissipated. The withdrawal of the Penang Chinese Association from the program is evidence of the change.

Reasons for the volunteers' loss of enthusiasm were their unfamiliarity with China's internal conditions, the differences in living standards and customs, poor pay, and ill treatment. For instance, sixty-two mechanics deserted in July, 1939, because of ill treatment. ${ }^{6}$ Complaints and disturbing news of the state of the volunteers seeped out of China, prompting Tan Kah Kee to send an investigation team to Yunnan and Burma in August, 1939. The findings of the team, as reported to Tan, confirmed the legitimacy of the reported grievances. The report said in part: "Facilities of depot stations [in Kunming] were extremely poor. ... Every Chinese from the South Seas region had lost his healthy look and appeared very sick. It is painful to watch him [suffering]." Tan sent a telegram to Generalissimo Chiang Kai-shek and the KMT Military Council to call their attention to the deplorable state of the volunteers, of the Burma Road, and of its administrators, asking them to make immediate improvements. Nothing was done to remedy the situation, for more revolts and desertions were reported in the early months of 1940. In February, 1,800 volunteers working on a southwestern route fled from Yunnan because they could not endure the cruelty and poor pay; a volunteer corps organized by the Huichou Chinese Association mutinied in March. ${ }^{8}$ Causes for these incidents were, according to deserters, "poor treatment, contrary to promises made by authorities; poor clothing, shelter, and medical care; and the low morale of administrators and too much red tape." ${ }^{\text {A }}$ As a result, in February, the Penang Chinese Relief Fund-Raising Association cancelled plans to send its fifth voluntary service corps and withdrew from the program. After these incidents, enthusiasm decreased considerably, and the number of volunteers from Malaya dropped, though 
Chinese associations in French Indochina and Burma continued to send a small number of volunteers until the Yunnan-Hanoi-Haiphong Road and the Burma Road were forced to close in the summer of $1940 .^{10}$ Chinese in Burma, however, resumed the program after the Burma Road reopened in October.

A serious consequence of these incidents was Tan Kah Kee's entanglement with the KMT officials. Twice he visited the Burma Road and the volunteers working there-on his inspection trip with the comfort mission and then on his way home. After his first visit, he advised KMT officials to correct the conditions that had caused some of the volunteers to have unhappy experiences. On his way back to Singapore in late 1940, he saw the conditions on the Burma Road unimproved: hundreds of the volunteers who had completed six months' training were sitting idle with no definite assignments. ${ }^{11}$ This was one of the causes of his disenchantment with KMT officials.

It is difficult to assess the contribution of the volunteers to China's capability to resist the Japanese aggressors because of its limited nature. Clearly the responsibility for bringing the program to its unfortunate end lay entirely in the incompetency and insensitivity of KMT government high bureaucrats. The Nanyang Chinese had a legitimate right to demand that KMT officials correct their mistakes since the NCRGA had assumed full financial obligation for the project, including volunteers' travel expenses to and from China. By its own inexcusable mistakes, the KMT government discouraged the program, engendering ill feeling among Nanyang Chinese leaders. The symptoms of the malady that caused the demise of the KMT government in 1949 were already evident.

Another major program the NCRGA undertook was sending comfort missions to China to show "the gratitude of the Nanyang Chinese to fighting men at front and at home, to manifest their determination to support the fatherland, and to see the real situation in China. ..."12 As Tan Kah Kee recorded in his memoirs, the idea of sending the missions was conceived in the winter of 1939 for the purpose of inspecting conditions in agriculture, opium-smoking, industries, imports, transportation, telecommunications, education, secret societies, and the morale of the Chinese people, both civilians and soldiers. ${ }^{13}$ The program, however, did not have a propitious beginning; Tan met strong 
dissent within the NCRGA, which pointed out the extravagance of the program. Even after participants had been selected, some leaders still objected to the project on the grounds that most of the members were Communists. Tan wrote in his memoirs that he pacified these unsympathetic colleagues because "the Chungking government understood [his] sincerity."14

Candidates for the mission were carefully selected on the basis of personal integrity, past record in anti-Japanese activity, fluency in Chinese, and ability in delivering speeches. Of the fifty-four chosen, forty-three were from Malaya and the others from the Philippines, French Indochina, the Dutch Indies, Burma, and Hong Kong. As I have already pointed out, Thai-Chinese did not participate. ${ }^{15}$ Tan Kah Kee assumed the general directorship of the mission, and he flew to Chungking by way of Kunming. The mission, in two troupes, arrived in Chungking on April 16, after having visited Kunming and Kueiyang, where they were greeted by high government and military dignitaries; Lung Yun, chairman of Yunnan Province; and mayors of the cities. Responding to the red-carpet welcome at Kunming, representatives from Penang pledged one million yuan for building rubber factories at Chungking, Kueiyang, and Kunming. These plants reportedly started operations as soon as the fall of $1940 .^{16}$

Upon their arrival in the Chinese wartime capital, the Nanyang Chinese delegates received a warm welcome from high government leaders. For the next few days, members of the mission were entertained at a round of receptions given by President Lin Shen; Chairman Chiang Kai-shek; Finance Minister Kung Hsiang-hsi; General Ho Ying-ch'in, Chief of General Staff; Chang Chün, a member of the Central Executive Committee; Wang Shih-chieh, Education Minister; and Hsü Shih-ying, Chairman of the Fund-Raising Committee. At the reception given by Generalissimo and Mme. Chiang Kai-shek on April 20, P'an Kuo-ch'ü, leader of the mission from Malaya, "voiced strong support of overseas Chinese to the nation under Chiang Kaishek," and "assured his fellow countrymen that every Chinese abroad is backing [the] motherland to win the war." Referring to Wang Ching-wei's defection and its effect upon the Chinese, P'an asserted that he "saw no result in ... the Chinese population in the tropical territories because the overseas Chinese are most patriotic and have 
unwavering confidence in the ultimate triumph." He concluded by pledging the faithful upholding of San-Min-Chu-I, support for the Nationalist government of China, obedience to its leaders, and assistance to China's resistance war. Chairman and Mme. Chiang, in response, thanked him and "lauded the patriotism of the overseas Chinese." 17 At another welcome party, President Lin Shen urged the overseas Chinese representatives to support China's war effort because, he said:

... only through wholehearted support of all overseas Chinese can we achieve this goal [real peace]. Every dollar that overseas Chinese save and send to the motherland counts for obtaining the final objective. . . . Peace at any price at this moment would mean a humiliation both to our descendants and ancestors. ${ }^{18}$

In response to the government's appeal for contributions, three representatives from Kuala Lumpur donated 300,000 yuan for relief funds in Kwangtung and 2,000,000 yuan for land development. ${ }^{19}$

Tan Kah Kee, who had arrived in China on March 24, had been meeting with government leaders. On every occasion, he denounced the Wang Ching-wei government and pledged his loyalty to the government of Nationalist China, and by short-wave radio he spoke to the Nanyang Chinese of his personal impressions of China and of investment opportunities there. To demonstrate the loyalty of the Nanyang Chinese to the Nationalist government, Tan announced that they had underwritten the establishment of a pharmaceutical factory in Singapore and its administrative office in Chungking and that by early 1940 they had contributed to relief 220 million yuan. ${ }^{20}$ But privately Tan was reported to have told government officials that the "Nanyang Chinese had given since the war on the monthly average of six to seven million yuan, and that this was the maximum limit of their capability." Sun Fo, president of the Legislative Yüan, explained that the government's need of money to finance the war was acute, urging Tan to exert more effort to give to China. Tan, however, was noncommittal. ${ }^{21}$

Whatever was Tan's inner feeling, he did not express it on the eve of his departure on the observation trip. He probably kept it to himself, preferring to make a statement at the end of the journey. On May 1, the mission, divided into three groups, started on its inspection trip to the North and the Northwest, to the central region, and to the South 
and the Southwest. Tan appears to have joined the first group and then travelled independently to see Fukien and the Southwest. For the next two months, the delegates combed the country, travelling through most of the unoccupied territories, and returned to their respective countries in late July. They were "impressed by the great progress" China had made and by the high morale of the Chinese people. "I am very much moved," one of the group leaders told a reporter, "by the improvement the fatherland has made and I will do my best, when I get home, to tell my people about it, so that they will give more to the fatherland." Another representative was elated to find abundant food and said that the "spirit of the morale of the Chinese in Hunan is high, constituting the backbone of resistance and national reconstruction. The Nanyang Chinese should follow the example of Hunan to meet the national crisis and to recapture the territories lost to the enemy. We overseas Chinese prefer to endure poverty in a strong nation rather than to enjoy wealth in a weak nation." ${ }^{, 22}$

All was not as rosy in China as it appeared to these excited observers, however. As I have discussed in previous pages, to an astute leader like Tan Kah Kee, China under the KMT rule was not what he had expected it to be. Except for a decline in opium-smoking in Communist-controlled Kansu, Tan was profoundly disappointed by the deterioration of the KMT-Communist coalition, by conditions in his native Fukien, by the maladministration of the Burma Road, and by the low morale of citizens and corrupt officials in Chungking. Many things did not add up to what he had been told by KMT officials at the beginning of the trip, and his inspection confirmed his doubts. According to Ichikawa, Tan, while still in Chungking, had already begun to suspect several aspects of government operations. His skepticism centered on several points. First, the government had received, Tan was told, more than 700 million yuan from Southeast Asia and over 300 million yuan from other parts of the globe, totalling approximately 1.1 billion yuan. Subtracting 1 billion yuan, the total of the proceeds from bond subscriptions and remittances, the government would have only 100 million yuan in the treasury, but it had printed 2.2 billion yuan of paper money. Furthermore, the government had been negligent in preparing a statement of accounts for 
contributions from abroad. Second, many patriotic overseas Chinese, who had invested their savings for the development of transportation in their native country, Tan has written, faced bankruptcy because the government had neglected to take steps to protect them, and bureaucrats had been unresponsive to the investors' request to remedy the condition. Third, the KMT government, Tan suspected, had not been sharing contributions from abroad with the Communists. Finally, Tan was certain that there was no clear-cut understanding between the KMT and the Communists about the private ownership rights of government bonds, with the consequence that the bonds might become scrap paper after the war. ${ }^{23}$ His journey across the country seemed to strengthen his doubts about these and many other matters. The result was his outburst of criticism of irresponsible government bureaucrats and officials that endangered his relations with them and accentuated the split between the NCRGA and the KMT in 1941. Paradoxically, the goodwill mission sowed the seeds of bitterness.

\section{Monetary Contribution}

The most tangible measurement of South Seas Chinese contribution to wartime China can be made from a study of their response to Chungking's request for cash contributions. The KMT government exhausted many means and devices under the campaign slogan"Give Money and Give Strength"- to attract monetary aid from the Chinese abroad. The Chinese in Southeast Asia responded generously, although admittedly there were cases of coercion. They gave money; bought war and government bonds; donated airplanes, ambulances, trucks, drugs, and clothes; and invested in industries for the development of China's hinterland. Indies-Chinese footed the bill for the maintenance of the Chinese Red Cross at a cost of $\$ 500,000$ monthly. They also collected 10,058 guilders and 1.2 million quinine tablets. Chinese in the Philippine Islands raised more than $\$ 15$ million to buy one squadron of airplanes, and Malayan Chinese donated $\$ 345,743$ for the purchase of winter clothes for Chinese soldiers. ${ }^{24}$

Shortly after the Japanese armies had overrun Southeast Asia in the Pacific War, Yü Hung-chün, vice Minister of Finance, was quoted as saying that China's financial loss from the Japanese conquest of the South Seas would amount to "a few billion yuan." "In the past 
several years," he said, "we have sold 300 million yuan of war and government bonds, of which the Nanyang Chinese have subscribed more than one-fifth. Besides, they have donated approximately 1.5 billion yuan in various forms of contribution. The Allies lost their territories; we lost our vital source of financial revenue."25 The figure is exaggerated but still conveys the message of the importance of overseas Chinese contributions as one of the principal sources of revenue to finance the war. The importance of the Nanyang Chinese to the Chungking government's war economy can be seen from a long list of distinguished KMT visitors; the regime sent a host of its high officials as soon as the Sino-Japanese war broke out and continued to send them almost up to the beginning of the Pacific War. They went to the tropical territories to solicit contributions, economic aid, and bond subscriptions and to cement good relations with the Nanyang Chinese communities, as shown in Table $2 .^{26}$

TABLE 2

A List of KMT Officials Who Visited Southeast Asia, 1937-1941

\begin{tabular}{|c|c|c|c|}
\hline Name & Objective & Destination & Date \\
\hline Kung Hsiang-hsi & To promote contributions & $\begin{array}{l}\text { Singapore, } \\
\text { Manila }\end{array}$ & Oct., '37 \\
\hline Tiao Tso-ch'ien & " & Malaya & " \\
\hline $\begin{array}{l}\text { Teo Eng Hock } \\
\text { (Chang Yung-fu) }\end{array}$ & " & " & " \\
\hline Hsiao Chi-shan & " & " & " \\
\hline Ch'en Shu-jen & $"$ & Philippines & $"$ \\
\hline P'an Kung-chan & $" \prime$ & $" 1$ & $"$ \\
\hline Liu Hao-chu & $"$ & $"$ & $"$ \\
\hline Tai Kui-sheng & $\begin{array}{l}\text { To promote bond sub- } \\
\text { scriptions }\end{array}$ & " & $\prime \prime$ \\
\hline Mo Ying-kuan & $\begin{array}{l}\text { To raise funds for } \\
\text { wounded soldiers and } \\
\text { organize medical corps }\end{array}$ & Singapore & Dec., '37 \\
\hline Sun Fo & $\begin{array}{l}\text { To promote the National } \\
\text { Salvation Movement }\end{array}$ & $"$ & Jan., '38 \\
\hline Ch'iu Cheng-t'ou & $"$ & $"$ & Aug., '38 \\
\hline Liu Chin-shen & $"$ & " & "I \\
\hline Yü Han-mou & $\begin{array}{l}\text { To raise funds for military } \\
\text { expenditure }\end{array}$ & Thailand & " \\
\hline Ting Pe'i-lun & $"$ & " & $"$ \\
\hline Ting Pe'i-tz'u & $"$ & $"$ & May, '38 \\
\hline
\end{tabular}


TABLE 2 (concluded)

\begin{tabular}{|c|c|c|c|}
\hline Name & Objective & Destination & Date \\
\hline Wang Cheng-t'ing & $\begin{array}{l}\text { To organize San-Min- } \\
\text { Chu-I Youth Corps }\end{array}$ & Manila & ?, ’39 \\
\hline $\begin{array}{l}\text { Li Ssu-yüan and } \\
\text { Tai Kui-sheng }\end{array}$ & $\begin{array}{l}\text { To promote bond sub- } \\
\text { scriptions }\end{array}$ & Southeast Asia & Aug., '39 \\
\hline $\begin{array}{l}\text { Kao Shih-heng and } \\
\text { Wang Kung-ch'üan }\end{array}$ & $\begin{array}{l}\text { To study means to sell } \\
\text { national goods }\end{array}$ & $"$ & Sept., '39 \\
\hline $\begin{array}{l}\text { Ch'en Cho-hsiung and } \\
\text { Tseng T'ung-ch'un }\end{array}$ & To disseminate information & $\begin{array}{l}\text { Malaya, Fr. } \\
\text { Indochina }\end{array}$ & Late '39 \\
\hline $\begin{array}{l}\text { Yao Pai-lung and } \\
\text { Hsü Kuan-chih }\end{array}$ & I & $\begin{array}{l}\text { Philippines, } \\
\text { Dutch East } \\
\text { Indies }\end{array}$ & Late'39 \\
\hline Ch'en Hsiao-wei & $"$ & Malaya & Nov., '39 \\
\hline Tai T'ien-ch'ou & To raise funds & Burma, India & $\begin{array}{l}\text { Late '39 } \\
\quad \text { Early '40 }\end{array}$ \\
\hline Wu T'ieh-ch'eng & $T$ & $\begin{array}{l}\text { Philippines, } \\
\text { Malaya } \\
\text { East Indies, } \\
\text { Burma }\end{array}$ & $\begin{array}{l}\text { Late '40 } \\
\text { Early '41 }\end{array}$ \\
\hline $\begin{array}{l}\text { Ma T'ing-huai and } \\
\text { Huang Neng-jung }\end{array}$ & $\begin{array}{l}\text { To disseminate } \\
\text { information }\end{array}$ & Malaya & Aug., ' 40 \\
\hline Tiao Tso-ch'ien & " & Malaya & Apr., '41 \\
\hline Wen Yü-ho & $\begin{array}{l}\text { To organize San-Min-Chu- } \\
\text { I Youth Corps }\end{array}$ & $\begin{array}{l}\text { Dutch East } \\
\text { Indies }\end{array}$ & '41 \\
\hline Sun Weng-t'ao & $"$ & Fr. Indochina & '41 \\
\hline Lin Tso-mei & $"$ & Philippines & '41 \\
\hline Lü Chia-wei & To inspect party affairs & Malaya & '41 \\
\hline Sha Kuo-chen & $"$ & Philippines & '41 \\
\hline Huang T'ien-chüeh & $"$ & $" 1$ & '41 \\
\hline
\end{tabular}

It is apparent from Table 2 that the Chinese government concentrated its campaign effort on Malaya-Singapore and the Philippines, since the Chinese in both countries were relatively well off and the British pound and the U.S. dollar enjoyed a higher exchange rate than those of the other currencies. In addition, the Nationalist government sent a number of cultural missions such as the Chinese Buddhist Association for International Visits, the Wuhan Chorus Group, the New China Drama Team, the Chinese Moslem Association, the Chinese Cultural Association, and others, each of them succeeding in raising a considerable sum of cash donations. ${ }^{27}$

Before I proceed with the discussion, I must explain that the 
figures in the following pages are by no means definite because they were published fragmentarily by Chinese sources or were estimated by various sources. Moreover, there is no uniformity in arriving at an estimate of contributions for a given period; as a result, figures overlap and duplicate. Nor is there agreement in expressing the monetary unit; evaluation is extremely difficult. Furthermore, there is very little information about money siphoned to the Chinese Communists; therefore, I shall deal primarily with questions pertinent to contributions destined for Chiang Kai-shek's war coffers.

The most reliable figure for contributions and bond subscriptions for the period of fifteen months from July, 1937, to September, 1938, was in an oral report given at the first meeting of the NCRGA, held in October, 1938. A breakdown of the figure is shown in Table 3.

TABLE 3

A Breakdown of Nanyang Chinese Contributions From July, 1937, to OCTOBER, $1938^{28}$

\begin{tabular}{|c|c|c|}
\hline Country & Contributions & Bond Subscriptions \\
\hline Malaya & $19,577,194$ yuan & $12,864,105$ yuan \\
\hline Dutch East Indies & $\begin{array}{l}5,092,318 \\
\text { (plus } \$ 219,568 \text { and }\end{array}$ & $\begin{array}{c}1,970,345 \\
1,414,961 \text { guilders })\end{array}$ \\
\hline Philippines & $5,242,020$ & $5,510,300$ \\
\hline French Indochina* & $4,400,000$ & \\
\hline Thailand* & $8,000,000$ & \\
\hline Burma & $2,103,904$ & $1,212,810$ \\
\hline 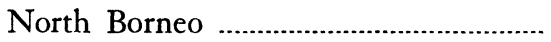 & 857,892 & 214,000 \\
\hline Total: & $45,363,328$ & $21,771,560$ \\
\hline
\end{tabular}

* The figure is a total of contributions and subscriptions.

According to this report, the Nanyang Chinese contributed to the treasury of the Nationalist government as much as $67,134,888$ yuan, plus SS $\$ 219,568$ and 1,414,961 guilders. Allowing for some "statistical inaccuracy" and "unreported or unaccounted" funds, because some delegates (Thai-Chinese representatives) were unable to give an accurate report to the meeting, ${ }^{29}$ the total figure was likely larger than it appeared. Further evidence for contributions that the KMT government received from the Nanyang Chinese between November, 1938, and December, 1940, is found in a report presented to the second NCRGA conference in March, 1941. It shows that the Nanyang Chinese poured into the war chest an estimated 147,748,000 yuan, plus 
30 million yuan, during a twenty six-month period. Table 4 is a breakdown of the figure.

TABle 4

A Breakdown of Nanyang Chinese Contributions From November, 1938, to December, $1940^{30}$

\begin{tabular}{|c|c|c|c|}
\hline Country & Contribution & $\begin{array}{c}\text { Monthly Quota Assumed } \\
\text { By Nanyang Chinese }\end{array}$ & $\begin{array}{l}\text { Quota for } 26 \\
\text { Month Period }\end{array}$ \\
\hline Malaya & $85,430,000$ yuan & $1,337,000$ yuan & $34,762,000$ yuan \\
\hline Philippines & $14,880,000$ & 500,000 & 13,0 \\
\hline Dutch East Indies .. & $31,530,000$ & 544,000 & $14,144,000$ \\
\hline French Indochina & $1,564,000$ & 250,000 & $6,500,000$ \\
\hline Burma & $8,030,000$ & 300,000 & $7,800,000$ \\
\hline 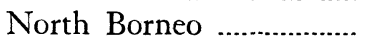 & $3,313,000$ & 24,000 & 624,000 \\
\hline Thailand & $\begin{array}{c}3,000,000^{*} \\
30,000,000^{* *}\end{array}$ & & \\
\hline Total: & $177,748,000$ & & $76,830,000$ \\
\hline
\end{tabular}

* The figure represents only for the November, 1938-October, 1939 period. Taken from Mantetsu SCJ, Kakyō chōsa ihö I, p. 83.

** A leftover that could not be remitted to China because of foreign exchange control.

A few things need to be noted in Table 4. First, there is no mention of a 1940 figure reported from Thailand. The omission was attributed to the fact that Thai-Chinese officials did not attend the meeting; it confirms the assertion that "representatives of several Chinese associaions in Thailand" attending the conference were not official delegates. Second, the Chinese in all the countries except French Indochina did exceedingly well in fulfilling their quota. The poor showing in French Indochina also supports the evidence that there was widespread discontent over making contributions, which prompted the Chungking government to rush soliciting agents to Saigon to revitalize the campaign. Excepting those in French Indochina, the Nanyang Chinese gave twice as much as the quota. However, these figures must be read with reservations, not so much to discount Chinese response as to put them in a proper historical context. During 1940, the Chinese national currency was devaluated by 50 per cent compared with its value in 1939. ${ }^{31}$ Therefore, the foreign currency that Nanyang Chinese sent had a better exchange rate in China. The depreciation of the yuan seemed to have an adverse effect on the Chinese desire to contribute, since exchange rate of the foreign currency they sent to China would inflate as value of Chinese currency decreased. This is probably why Tan Kah Kee complained of the 
slackening of contribution zeal at the second NCRGA meeting. Tan told the audience that seventy-three million yuan had been contributed during 1940, but that the amount was three million yuan more than the 1939 contribution. This in effect represented a 50 per cent decrease, ${ }^{32}$ he explained, since the 1940 total remained at the 1939 level although the yuan had depreciated 50 per cent. Although Tan ascribed the drop in part to decreased enthusiasm for contribution among the rich and the local-born Chinese,$^{33}$ he must also have been aware of the increasing difficulty of collecting money from wage earners and lowand middle-class merchants, who had been taxed most heavily by the contribution campaign. Probably realizing that this group could no longer contribute heavily, Tan used the forum of the NCRGA to appeal to local-born and wealthy Chinese for contributions. He may have become aware of the inequity of the contribution system; the rich Chinese may not have given in the same proportion to their wealth as the poor workers and merchants, particularly in view of the fact that the economy of Malaya had been booming since the outbreak of the European war in September, 1939. The charge of increasing reluctance to contribute is difficult to prove. There is some evidence among the Indies-Chinese to substantiate the accusation, but it is too limited to allow the generalization that the local-born Chinese were not patriotic, as Tan's remark seemed to imply. It must be borne in mind, however, that the National Salvation Movement was largely a China-born Chinese movement in which few local-born Chinese leaders took active part. His statement, therefore, should be read with this fact in mind. An activist and a China-born Chinese, Tan was impatient with Chinese less patriotic than he, and he judged the patriotism of others by his own.

No itemized figure for 1941 is available. What appears to be the most trustworthy estimate for the period was published by the Overseas Chinese Affairs Commission of the Nationalist government, Taiwan, in 1956. This agency reported that the Nanyang Chinese "donated" $106,540,574$ yuan in $1941 .^{34}$ There is no way of determining whether the figure includes proceeds from the sale of bonds. Moreover, the figure is extraordinarily large for one year. It is probable that the 1941 figure was calculated at an inflated exchange rate since the yuan continued to lose value throughout the war years. Be that as 
it may, the Chinese in the South Seas poured 355 million yuan into the coffers of the Chiang Kai-shek government from the beginning of the Sino-Japanese war until the outbreak of war in Southeast Asia.

Let us now look at KMT government's records of receipts from contributions. According to a report published by the Overseas Chinese Affairs Commission, it received 294,396,358 yuan from Chinese all over the world between July, 1937, and October, 1940. Nanyang Chinese (including Chinese in India) were credited with 217,617,000 yuan, or about 74 per cent. Table 5 shows a breakdown.

TABLE 5

KMT Government's Receipt of Contributions from the Nanyang Chinese Covering the Period from July, 1937, to October, $1940^{35}$

\begin{tabular}{|c|c|}
\hline Country & Contributions \\
\hline Singapore* & $125,768,000$ yuan \\
\hline Dutch East Indies & $37,569,755$ \\
\hline Philippines & $26,584,357$ \\
\hline Thailand .. & $10,429,090$ \\
\hline French Indochina & $7,390,871$ \\
\hline India and Burma & $9,885,248$ \\
\hline Total: & $217,627,321$ \\
\hline
\end{tabular}

* The designation "Singapore" can be assumed to mean British Malaya.

This figure, however, does not include contributions attributed to National Defense Bonds and Gold Bonds. General Wu T'ieh-ch'eng, chairman of the KMT Overseas Affairs Department, provided figures for bond subscriptions that help us approximate the total contribution of the Nanyang Chinese. He said that the overseas Chinese in Asia (i.e., Southeast Asia) had purchased National Salvation Bonds worth 32,103,329 yuan and National Defense Bonds valued at 4,797,234 yuan, in addition to $\$ 16,328$ and $£ 4,805$ in Gold Bonds, in twenty-nine months ending December, $1939 .^{36}$ Adding the total of these figures to the 217,627,000 yuan in Table 5, we arrive at 227,324,000. This is an approximate estimate of money that had gone into the war chest by the end of 1940, and it corresponds roughly to a grand total of $244,882,888$ yuan that the NCRGA said it had sent to the Nationalist government by the end of 1940. This is a conservative estimate since the Wu figure does not include funds collected by the Chinese Women's War Aid Association in the Philippines, Chinese in Palembang and Surabaya, and Relief Associations of Singapore and Burma; nor does it include funds 
for medical aid and drugs contributed by Chinese in the Dutch East Indies, the Philippines, French Indochina, and Singapore; nor does it include funds contributed by Filipino-Chinese for airplanes and by Malayan Chinese for the re-opening of the Burma Road; nor funds for rice, tanks, ambulances, raincoats, winter clothes, and rubber shoes; nor money directly sent to field armies and the Chinese Communists; nor a figure for October, 1938, from the Nanyang Chinese and a 1940 figure from Thailand. One will never know how much these contributions amounted to. It seems fair to assume that they represent about onetenth of the total, 355 million, given by the end of 1941. In other words, a rough estimate of the money that the Chinese government received from the Nanyang Chinese can be computed at upwards of 390 million yuan. This compares well with $354,072,000$ yuan, a postwar figure published by the KMT Overseas Chinese Commission, that was acknowledged by the agency for the period from July, 1937, to December, $1941 .^{37}$ It means that the Nanyang Chinese gave an average of 7.1 million per month during the same period, a feat rarely matched by any other minority group abroad. At the same time, the 7.1 million average is consistent with Tan Kah Kee's private remark to Sun Fo that 6 to 7 million yuan was "the maximum limit of their capability." The Nanyang Chinese could have given more, if there had been no foreign currency restrictions on remittances, as Tan was quoted as having said, ${ }^{38}$ but he probably knew that the achievement was not entirely reached by voluntary contributions but by considerable "persuasion."

It is no wonder that the Chinese government regarded the Nanyang Chinese as an important source of revenue for wartime expenditures. The goal of Nanyang Chinese contribution, reiterated Kung Hsianghsi, was to share "one-fourth of the military expenses" of the KMT government. ${ }^{39}$ They achieved that goal in the first year of the war. Arthur Young, a former financial adviser to Chiang Kai-shek, gave China's first year (July, 1937 to July, 1938) of military expenditures as 1,388 million yuan; ${ }^{40}$ one-fourth of it was 347 million yuan. In the same period the Nanyang Chinese poured 67.1 million yuan into the treasury of the KMT government, plus regular yearly remittances estimated at 400 to 500 million yuan. ${ }^{41}$ The sum of these two figures is 
somewhere between 467.1 and 567.1 million yuan, not counting other contributions.

In conclusion, the monetary and material contributions of South Seas Chinese to China's war effort were tremendously impressive; they are more impressive in view of the fact that a real economic boom in the tropical region did not start until September, 1939, when war erupted in Europe, raising prices of rubber, tin, iron ore, palm oil, and rice, and that the Chinese achieved the remarkable record of consistency and generosity under various difficulties and handicaps, including discriminatory policies enforced by some Southeast Asian countries.

Before leaving a discussion of contributions, a brief examination of Chinese contributions in each country in proportion to the size and composition of the population is in order. For this purpose, the period between November, 1938, and October, 1939, is selected because contribution fervor appears to have reached its highest point during that period.

\section{TABLE 6}

Nanyang Chinese Contribution Per Capita November, 1938, to October, $1939^{42}$

\begin{tabular}{|c|c|c|c|}
\hline Country & Population** & Contribution & $\begin{array}{l}\text { Unit-1,000 } \\
\text { Per Capita }\end{array}$ \\
\hline Philippines & 250,000 & 7,526 yuan & 34.10 \\
\hline Burma & 300,000 & 4,035 & 13.45 \\
\hline British Malaya ……........................ & $2,390,000$ & 30,459 & 12.74 \\
\hline Dutch East Indies & $1,500,000$ & 12,766 & 8.25 \\
\hline French Indochina & 500,000 & 1,564 & 3.13 \\
\hline Thailand & $2,500,000$ & 3,200 & 1.28 \\
\hline
\end{tabular}

** Taken from Japan, Taiwan Takushoku Kabushiki Kaisha, Nanyō kakyö to sono taisaku (Taihoku, Taiwan: Taiwan Takushoku Kabushiki Kaisha Chōsabu, 1941), p. 4.

It is plain, from Table 6, that the Filipino-Chinese showed the best contribution per capita, which was close to 2.6 times that of the Malayan Chinese. The highest individual donation-by the Chinese in the Philippine Islands-testifies to the well-organized, well-lubricated machinery of their fund-raising drive, their relative wealth, greater economic stability than that of the Dutch Indies, a more valuable currency than the guilder and the baht, and the less prohibitive attitude of the Filipino and American authorities toward the Chinese fund-raising campaign than the one held by authorities in Malaya, the Dutch Indies, 
and Thailand. It is, therefore, understandable that the Chungking government singled out the Philippines, along with British MalayaSingapore, as the place to send a number of its VIPs, headed by Kung Hsiang-hsi and Wu T'ieh-ch'eng, to solicit contributions and to promote the sale of bonds.

The Chinese in British Malaya-including Singapore-gave far smaller sums of money per capita, but their total exceeded the totals of other Nanyang Chinese by a wide margin. The paradox is explained by the facts that the territory had the second largest overseas Chinese population (second only to that of Thailand) and that their contributions came largely from the poor laborers and the small merchants, as Tan Kah Kee and the Nanyang Siang Poh pointed out. ${ }^{43}$ The record of the Dutch East Indies, with the third largest Chinese population, reflects the basic attitude of the Dutch authorities toward the Chinese money raising campaign; they did not permit public auctions or propaganda for the sale of war bonds. Moreover, the moneyraising organization did not function as effectively there as it did in the Philippines and Malaya-Singapore. It is not difficult to explain the Thailand Chinese record of the lowest per capita contribution. Although Thailand had the largest overseas Chinese population, the Bangkok government's policy of repression toward the Chinese speaks for itself. From the beginning, the Chinese contribution campaign in Thailand was conducted underground and later any form of donation destined for China was prohibited. The contrasting attitudes of the Bangkok and the Manila governments toward the National Salvation Movement produced a sharp contrast in the results of the fund-raising drives. The lack of leadership in the Thai-Chinese community after the death of Hsiao Fo-ch'eng may also have had some bearing on the record.

It is difficult to deduce from this table or from other sources the extent to which the composition of Sinkheh and Baba affected contributions. As I have shown, Tan Kah Kee complained of the apathy of the local-born Chinese to the contribution drive. One long-time student of the overseas Chinese labored to point out that the Baba were much less patriotic than the Sinkheh. ${ }^{44}$ On the other hand, there was a sizable group of local-born Chinese in Thailand and the Philippines. The Chinese in the Philippine Islands gave the highest amount per 
capita and conducted an effective anti-Japanese operation. Though the Thai-Chinese contribution was the lowest, it must be remembered that nowhere was their poor record attributed to the composition of the China-born Chinese and the local-born Chinese, but rather to the political climate in which the Thai-Chinese had to operate their campaign. Therefore, on the basis of available evidence, it is hazardous to generalize that the Baba were less patriotic than the Sinkheh, perhaps with the exception of those in the Dutch Indies. In the Dutch Indies, where the local-born Chinese were close to 65 per cent of the population, the larger Baba population could have had some bearing on the poor record in contribution per capita, because they were loyal to Indonesia first.

\section{Remittances}

The second direct means by which millions of the Nanyang Huach'iao shared China's wartime expenditure was remittance. Remittances were the money Chinese abroad sent to their families or relatives for their support. Most of the Chinese abroad were originally emigrants who sought to make a better way of life abroad, but traditional ties with their families obliged them to remit money regularly to their parents and other relatives. The revenue from remittances had been not only one of the principal sources of income for those who were left behind in China, but also it had been invariably the largest foreign exchange receipt of the Chinese government before the SinoJapanese war, serving as an important stabilizer for China's balance of payments. As I will show, remittances kept China's economy and finance solvent, and money remitted in foreign exchange could be appropriated directly for the payment of arms and munitions. For these reasons, it is essential to examine Chinese overseas remittances and the nature and the extent of their contribution to the capability of the Chungking government to wage the war.

Before proceeding, it must be said that the figures which will appear on the following pages are at best approximate estimates since the computation is extremely complicated. Of all sources used in this study, no two give identical figures partly because of "differences in coverage, methods of computation, and years studied . . .," as Chunhsi Wu, the author of Dollars Dependents and Dogma, admits. ${ }^{45}$ 
There is no need to dwell upon the methods by which overseas Chinese remitted money to China and how much they sent before the outbreak of the Sino-Japanese war, since it is beyond the scope of this study. ${ }^{46}$ An average of total annual remittances between 1930 and 1936 has been estimated at 300 million yuan. ${ }^{47}$ The significance of such remittances is graphically demonstrated in a table of international balance of payments published by the Economic Research Section, the Bank of China. According to this table, China's deficit in the international balance of payments for the four years from 1933 through 1936 was 2,172,800,000 yuan; she received 1,030,000,000 yuan from overseas Chinese during the same period. ${ }^{48}$ In other words, overseas Chinese remittances covered 47 per cent of China's trade deficits. As Remer said when he studied overseas Chinese remittances for pre-war years, each time he "found it difficult to believe that the remittances could be as great as they seemed on examination to be," but each time he became "convinced by the supporting evidence." ${ }^{\prime 9}$ It was a matter of vital concern, therefore, for the Chungking government and for the Nanking government to maintain the inflow of remittances and to keep them from being diverted to the area occupied by their opponents.

In order to secure remittances from abroad through friendly channels, the Chungking government passed the Exchange Transaction Act in March, 1938. The legislation stipulated that overseas Chinese be requested to remit money through Chungking government-controlled banks or friendly foreign banks and that banks lower the fee for handling remittances. Furthermore, the government authorized the Bank of China, the Bank of Communications, and the Bank of Canton to open branch offices at Hanoi, Singapore, Penang, Rangoon, Batavia, Surabaya, and Manila. ${ }^{50}$ After the Japanese troops occupied and controlled China's southeastern coastal cities (Amoy, Swatow, Foochow, Canton, Chuanchow, Ch'aochow, Macao, and Hainan Island) and after the Wang Ching-wei government reopened facilities for receiving remittances at these Japanese-controlled ports, the Chungking government stepped up its efforts to prevent remittances from being diverted or re-channelled to the Japanese-occupied area. It opened a new channel in the Kunming area after Canton fell to the Japanese. In order to tighten control over remittances and insure their flow to Chungking, the KMT government passed two bills: the Act Regulating Overseas 
Chinese Remittances to the Enemy-Controlled Areas (August, 1939) and the Act to Attract Overseas Chinese Remittances (January, 1940)..$^{51}$

On the other hand, the Nanking government under Japanese guidance lost no time reactivating channels for overseas remittances in port cities that had fallen into the Japanese hands. As early as March, 1939, the Japanese government held a joint ministerial conference under the auspices of the Foreign Ministry to consider means of enticing overseas Chinese remittances and their investment capital to the Japanese-occupied area. By summer, decisions had been made to reopen agencies for accepting remittances and to establish an Overseas Chinese Affairs Office as well as a reception center at each port. ${ }^{52}$ The Japanese countermeasures were not very successful despite progress reports from Amoy, Swatow, Canton, and Haikow. For instance, a report from Swatow recorded that remittance agencies had received 82 million yuan from Thailand, Singapore, and other Nanyang centers during nine months (March through December) in 1940. The receipts were about equivalent to pre-war ones, but in the actual value of the Chinese currency in 1940, the report said, the 82 million yuan was worth much less than it had been in 1936. That the result was obtained only because Japanese policy permitted remittances to be sent to Chinese living outside the Japanese-occupied zone shows the difficulty the Japanese encountered. ${ }^{53}$ Not only did the receipts from remittances not reach the level of Japanese expectation but accommodations at reception centers, which were administered by bureaucrats from the Taiwan Government-General, were so poor that they were insulting to the dignity of the Chinese people. The deplorable conditions drew sharp criticism from Chinese residents and from the Japanese Navy's Amoy Liaison Office. Commander Koshiba Naosada, who was assigned to the Amoy Liaison Office in May, 1941, to study the remittance problem and measures to win overseas Chinese, was appalled by the way these centers were operated. These facilities, purported to be welcoming places for returnees, were no less than opium dens or whore houses, where returning Chinese were stripped of their life savings for a night's sensuous pleasures. These facilities were such an affront to local residents that they alienated the Chinese from the Japanese. With the 
sympathetic understanding of his superior officers, Koshiba succeeded in getting rid of the undesirable features of the facilities. ${ }^{54}$

With this observation on the remittance policies of Chungking and Tokyo, let us turn to the record of overseas Chinese remittances to the government of Nationalist China and their contribution to China's international balance of payments. In the absence of the reliable annual business report published by the Bank of China, which was discontinued after 1937, figures in Table 7 were selected from several sources. A few words of explanation for the following discussion are in order. Figures used in this section are sum totals of remittances sent by Chinese around the world. Approximately 90 per cent of the overseas Chinese lived in Southeast Asia, and generally the Nanyang Huach'iao accounted for 75 per cent of the total remittances.

Table 7 shows remittance figures and their proportionate relationship to China's balance of payments deficits from 1936 and 1941. Remittances from the Chinese overseas increased each year during this period. The table reveals that the 1937 remittance figures, whichever one may accept, offset three to four times the deficit created by excess imports for that year-115 million yuan..$^{55}$ In 1938 , remittances rose to a level ranging from 479 to 600 million yuan, an increase of 120 to 150 million yuan. Explaining the phenomenon, Kann, a student of foreign exchange based in Shanghai, ascribed the increase to overseas Chinese response to China's appeal for national salvation and to a favorable rate of foreign exchange. ${ }^{56}$ Remittances balanced the 1938 deficit (124 million yuan) by nearly four to five times. Moreover, the 1937 and 1938 remittance figures represented the second largest source of income in 1937, and the largest revenue item in 1938. Without remittance receipts, China would have had an unfavorable balance of international payments which would have seriously affected her wartime economy and her ability to resist the enemy in the first two years of the conflict. Acknowledging the importance of remittances in stabilizing China's wartime finance, the managing director of the Hong Kong and Shanghai Banking Corporation cited overseas Chinese remittances as a key factor in the stability of China's wartime economy. ${ }^{57}$

The remittances for 1939 and 1940 need to be examined carefully. Kann estimated 1939 remittances at 2,000 million yuan. It appears that 
TABLE 7

Nanyang Chinese Remittances and China's Balance of Payments, 1936-1941 (Unit-Million Yuan)

\begin{tabular}{lcccccc}
\hline Year & Exports & Imports & Deficit & $\begin{array}{c}\text { Overseas } \\
\text { Remittances }\end{array}$ & \multicolumn{2}{c}{$\begin{array}{c}\text { Overseas Remittances } \\
\text { Deficit }\end{array}$} \\
\hline 1936 & 706 & 942 & 236 & $304^{1}(320)^{2}$ & 129 & $(135)$ \\
1937 & 838 & 953 & 115 & $359^{1}(450)^{2}$ & 312 & $(391)$ \\
1938 & 763 & 886 & 124 & $479^{1}(600)^{3}$ & 387 & $(484)$ \\
1939 & 1,027 & 3,494 & 2,467 & $1,200^{4}$ & 49 & \\
1940 & 2,133 & 6,060 & 3,927 & $1,800^{5}(2,000)^{6}$ & 46 & $(50)$ \\
1941 & 11,017 & 2,901 & 8,116 & $2,100^{7}(2,296)^{8}$ & 26 & $(29)$ \\
\hline
\end{tabular}

${ }^{1}$ Matsusaki Yūichirō, Chügoku Seijikeizai Sōron, Tokyo, 1960, cited in Wu, Dollars Dependents and Dogma, p. 16.

${ }^{2}$ Edward Kann's estimates cited in Mantetsu Chōsabu, Senji Shina keizai, p. 10; Yüan Mei-yin, K'ang-chan ssu-nien lai chi ch'iao-hui and Ch'en Shu-jen, chairman of the KMT Overseas Chinese Affairs Commission, cited in Japan, Shanhai Nippon Taishikan, Tokubetsu chōsahan, Jükei no Senji kokusai to Kakyō sōkin, pp. 24, 27.

${ }^{3}$ Kann's estimate cited in Mantetsu Chōsabu, Senji Shina keizai, p. 10; Yüan, K'ang-chan ssu-nien, cited in Japan, Shanhai Nippon Taishikan, Tokubetsu Chōsahan, Jükei no Senji kokusai to Kakyö sōkin, p. 27. Finance and Commerce (January 25, 1939), cited in Japan, Okura Daijin Kambō Zaisei Keizai Chōsaka, Shina no Senji zaisei (Tokyo: Okurashō, 1939), p. 86.

${ }^{4} \mathrm{Ku}$ Ling-ch'ün, former president of the Bank of Kwangtung, cited in Japan, Shanhai Nippon Taishikan Tokubetsu Chōsahan, Jükei no Senji kokusai to Kakyō sōkin, p. 24; Ma Ch'ao-szu, a member of the KMT Central Committee, in Kuo-chi ching-chi chou-pao (May 10, 1941); Takahashi Ryōzō, "Kakyō sōkin no en-Shō sei ni tsuite," Shina, XXXII, No. 3 (March, 1941) pp. 51-59; Ide Kiwata, Nanyō to Kakyō, rev. ed. (Tokyo: Sanseidō, 1943), p. 36; Ta Kung Pao, August 30, 1941, cited in Nami Shūdan Shireibu, Kakyō sōkingaku no hyöka, p. 7.

${ }^{5}$ Yüan, K'ang-chan ssu-nien, and Jen Yeh-yüan, an Overseas Chinese Bank official, cited in Japan, Shanhai Nippon Taishikan Tokubetsu Chōsabu, Jükei no Senji kokusai to Kakyö sōkin, pp. 24, 27; Robert W. Barnett, "Shanghai Exchange Market," Far Eastern Survey, X, No. 10 (June 2, 1941), pp. 111-116.

${ }^{6}$ Cheng Yen Pao, August 3, 1941, and Chung Mei Jih Pao, August 30, 1941, cited in Mantetsu Chōsabu, Senji Shina keizai, pp. 29-30, Ta Kung Pao, August 30, 1941, cited in Nami Shūdan Shireibu, Kakyō sökingaku no hyōka, p. 7.

${ }^{7} T$ s'ai-cheng P'ing-lun, VI, No. 2, cited in Mantetsu Chōsabu, Sen̈i Shina keizai, p. 34; Hong Kong banking circles cited in Japan, Shanhai Nippon Taishikan Tokubetsu Chōsabu, Jükei no Senji kokusai to Kakyō sókin, p. 24. This is an estimate calculated on the basis of a figure for the first six months of 1941.

${ }^{8}$ Chang Kia-Ngau, The Inflationary Spiral (Cambridge, Mass.: M.I.T. Press, 1958), Appendix D., pp. 384-385, cited in Wu, Dollars Dependents and Dogma, p. 79.

This figure is calculated on the basis of the parity of C $\$ 18.82$ per US $\$ 1$ existed in August, 1941. Young, China and Helping Hand, p. 257.

he included in his figure both contributions and intangible capital flow-money, stocks, and bonds-from Southeast Asia and other parts of the world to Shanghai, sent there because of the fear of a freeze on capital assets as a result of the outbreak of war in Europe. For the purpose of this discussion, I do not consider capital flow from abroad as the KMT government's revenue until the capital was invested in the area controlled by the government. An estimated 500 to 600 million yuan of capital assets was reportedly transferred to Shanghai in 1939. 
Contributions, based on a monthly average of donations estimated at 7 million yuan in Southeast Asia, probably amounted to 100 million yuan or more in 1939, since we are computing contributions from Chinese all over the world. Contributions for 1939 could go even higher because the economy of Malaya boomed after the outbreak of the European War. ${ }^{58}$ A conservative estimate of the total of the capital flow and the contributions, then, is 700 million yuan. Subtracting 700 million yuan from Kann's calculation of 2,000 million yuan, the balance would be 1,300 million yuan, matching more or less the 1939 remittance figure in Table 7-1,200 million yuan. Even though 1,200 million yuan, compared with the 1938 figures, looks unusually high, the preceding analysis would justify the 1939 remittance figure. Despite the large remittances of 1,200 million yuan, they helped balance only 49 per cent of the 1939 trade deficit because the KMT government's deficit soared to 2,467 million yuan. It is also to be noted that 1,200 million yuan actually represented 480 million yuan at the 1936 value of the national currency because by 1939 the value of the yuan had dropped 60 per cent. ${ }^{59}$

Information for 1940 is scarce. The lower figure $(1,800$ million yuan) was supplied by Jen Yeh-yüan and the higher estimate $(2,000$ million yuan) by three Chinese sources, one of which drew the information from an economic journal published in Singapore. The reliability of either of these figures cannot be verified by official Chinese sources, but they seem to corroborate each other. The problem here is to determine whether they include contributions and capital flow from abroad. Barnett added them to his calculation, but the other sources made no reference to their effect. Assuming that both figures, that is, 1,800 and 2,000 million yuan, include contributions and capital flow, the 1940 figures represent a decrease, compared with the 1939 remittance estimate, on two accounts. First, by 1940, the yuan had depreciated 72 per cent of the 1936 value, a drop of 12 per cent compared with the 1939 value, ${ }^{60}$ with the consequence that overseas Chinese remittances had a higher exchange rate in China. In other words, overseas Chinese obtained the 1,800-2,000 million mark with a smaller amount of money than that of the previous year. Second, as was shown, contributions and capital inflow accounted for approximately 700 million yuan in 1939. On the assumption that about the same 
amount of money accounted for these two categories in 1940, the 1940 remittance figure would be at a level ranging from 1,100 to 1,300 million yuan. It is not much higher than the 1939 level, and it is even lower than the level of 1939, if one chooses 1,100 million yuan for the 1940 remittance figure. Nevertheless, the 1940 remittances, subtracting contributions and capital flow, covered about one-third of the Chungking government's international balance of payments.

In 1941, China's trade deficit sky-rocketed to 8,116 million yuan, but overseas Chinese remittances did not increase as sharply as in the past few years. Because I was unable to ascertain whether the following two remittance figures include contributions and capital inflow, discussion of them proceeds on the premise that they are parts of the total. One would expect that the flight of capital from abroad to Shanghai would have increased because of international crises-the fall of France, Belgium, and Holland; Hitler's apparently impending invasion of the British Isles in 1940; and Japan's southward thrust in 1941. Contrary to such expectation, there was no significant increase in 1941. This phenomenon seems to mean either that the reserve of overseas Chinese capital had been exhausted or that wealthy overseas Chinese had ceased to transfer their capital to Shanghai and, instead, had invested it in the land and industrial development of China's Southwest. In view of a phenomenal increase in investment in China's industries in 1940 and 1941, which coincided with the economic boom in Malaya, the second explanation is more plausible. It is also possible to argue that the relatively slight increase in 1941 remittances over the previous year's indicates that overseas Chinese financial capability had reached its limit. As already shown in the discussion of contributions, their economic ability reached its limits by 1940 or soon thereafter. It is all the more true of remittances, since the bulk of remittances came from the savings of wage earners. ${ }^{61}$

From the foregoing discussion, a few conclusions can be drawn. First, it is plain that there was a very intimate relationship between overseas Chinese remittances and China's international balance of payments position in the war years as in the pre-war years. Second, remittances maintained the solvency of KMT China's wartime economy and kept the government from bankruptcy, especially in 1937 and 1938. Recognizing the role of overseas Chinese remittances 
in China's wartime economy, Kung Hsiang-hsi, in a glowing tribute, attributed his government's financial stability to "the enthusiastic contributions of overseas Chinese in the shape of cash remittances. . ." Endorsing Kung's statement, General Wu T'ieh-ch'eng said: “This colossal inflow of funds [aiding China's balance of payments] . . . is partly responsible for the soundness of the nation's war finance." ${ }^{\text {"3 }}$ Finally, the KMT Central Executive Committee lavished its praise on the patriotic performance of their overseas compatriots, saying:

... In the course of 18 months of stubborn resistance and determined struggle, we have reduced the strength of our enemy, defeated his crack divisions, placed his army in the most difficult position and demoralized his forces, thanks to the leadership of our High Command and bravery of our officers and soldiers at the front. But our overseas Chinese have also played a great part. They have shown their deep devotion to their motherland, and have been most generous in making financial contributions to the Government. They are responsible for the soundness of our nation's war finance. Furthermore, through their efforts, international justice is being vindicated. . . . ${ }^{64}$

It was patent that China's wartime economy owed a great deal to overseas Chinese remittances. Beginning in 1939, the rate of increase in remittances could not keep up with the inflation of the Chinese currency. By that time, foreign countries, notably the United States, had come to China's rescue. Finally, in evaluating remittance returns, it should be mentioned that economic conditions in the South Seas improved in 1940, as the European war created increased demands for rubber and tin. Despite this favorable economic condition, the preceding study shows that overseas Chinese remittances from Southeast Asia remained at the two billion level in 1939, 1940, and 1941. One may safely conclude that two billion yuan was the limit of the ability of the Chinese abroad to contribute to China's wartime finances. Yet the limited financial resources of the Chinese abroad could not be expected to help perpetually to defray China's balance of payments deficits, especially when those deficits became astronomical after 1940 . What they gave to the Chiang Kai-shek government was an eloquent testimony of Chinese loyalty and duty beyond call. One should not take as propaganda Tan Kah Kee's statement at the second NCRGA meeting in 1941 that the Nanyang Chinese "had remitted more than three billion yuan to China in the past three years or more." ${ }^{\text {"5 }}$ It may represent a very conservative estimate, for another Chinese source cites five billion yuan as having been remitted to China by $1941 .^{66}$ 


\section{Investment}

The third way in which the Chungking government tapped revenue was to invite overseas Chinese investments into China in order to build industrial bases or to modernize obsolete industries. The fall of Wuhan and Canton to the Japanese made it all the more necessary for the Chinese government to develop a self-sustained economy in the Southwest to carry on the war of resistance. ${ }^{67}$ For this reason, great attention was devoted to the economic development of China's interior. As the initial step in building a new industrial complex in the hinterland, Chungking was able to draw floating capital from Shanghai and Hankow to the interior and remove industries from the coast to inland areas controlled by the KMT government.

The immediate problem facing the Chiang Kai-shek government was to seek a new source of money to invest in the industrialization program. Two resources were tapped in order to achieve the objective: foreign loans and the capital of the overseas Chinese. As Barnett noted, a tremendous amount of overseas Chinese capital flooded Shanghai as a result of the general economic instability created by the tension in Europe and Asia. ${ }^{68}$ It was under these circumstances that the KMT government announced the establishment of the Overseas Chinese Investment Information Office in early 1939.69 The newly created Office was to provide information and services for prospective overseas Chinese investors, as stipulated in the Regulations Governing Encouragement for Overseas Chinese Investments in Domestic Economic Undertakings During the National Emergency Period, which was enacted in November, $1938 .^{70}$

In spite of favorable terms the Overseas Compatriot Investment Encouragement $\mathrm{Act}^{71}$ offered prospective overseas Chinese investors, response was not at all encouraging until the end of $1939 ; 7^{72}$ from July, 1937, to that date, an estimated 400 million yuan was invested. ${ }^{73}$ Both Japanese and Chinese gave reasons for the relatively poor investment record. First, overseas Chinese investors were afraid of the loss of investment because of an inadequate guarantee against the risk involved and because of political instability in China. Second, the Chungking government did not provide sufficient information about investment opportunities. As a result, prospective investors abroad did 
not know what investment possibilities were available in China. Third, most of the Nanyang Chinese were wage earners and small shopowners; therefore, large capital investments were hardly to be expected from them. Fourth, those who had invested earlier remembered the high taxes they had paid on profits or harbored the bitter memory of a heavy investment loss in the Changchow-Amoy railways in Fukien and the Canton-Hankow railways in Kwangtung. Finally, there were no adequate facilities to handle remittances for investment. ${ }^{74}$ The Chungking government remedied these shortcomings and doubled its effort to attract investment by Chinese abroad. For instance, it sent General Wu T'ieh-ch'eng to the South Seas in 1940, on an investment promotion campaign trip; it invited leading Chinese businessmen from Southeast Asia (Tan Kah Kee and Aw Boon Haw), the United States (K'uang Huan-shun), Canada (Huang Chi-sheng), and other overseas Chinese groups for an inspection trip in the hinterland; it appointed a number of overseas Chinese to its legislative body to flatter them and called a conference on national finance policy; it established a committee to assist overseas Chinese who wished to return to China to engage in business $;^{75}$ and it raised investment interest rates in Chungking and Kunming to 7 per cent and 8 per cent, respectively, to attract idle capital in Shanghai, where the interest rate was 3 per cent. ${ }^{76}$ All these measures proved successful in enticing capital investment from abroad and from Shanghai, judging by an increase in investment in 1940 and 1941. According to the Chung Mei Jih Pao (March 17, 1941), in 1940, 30 to 35 million yuan had been invested every month in the hinterland industrial program, making the total for the year 396.4 million yuan. ${ }^{77}$ In 1941, the investment figure soared even higher; a report, reputedly "obtained from a Chinese state bank," claimed that in the first ten months as much as 800 million yuan had been invested in industries in Chungking, Chengtu, Kunming, Kueiyang, Kwangsi, Kwangtung, and Fukien and predicted that the figure would reach one billion yuan by the end of the year. ${ }^{78} \mathrm{~A}$ Japanese source calculated that nearly two and a half billion yuan of capital flow had arrived in China from abroad between July, 1937, and December, 1941, of which 1.6 billion yuan, or two-thirds, had been invested in the industrial projects in the area controlled by the Nationalist government. ${ }^{79}$

Information on the type and nature of the investments is hard to 
find. Table 8 shows a list of principal enterprises in which Nanyang Chinese either invested or planned to invest.

TABLE 8

A List of Principal Enterprises in Which Nanyang Chinese Had Invested or Planned to Invest as of 1941

(Unit-Yuan)

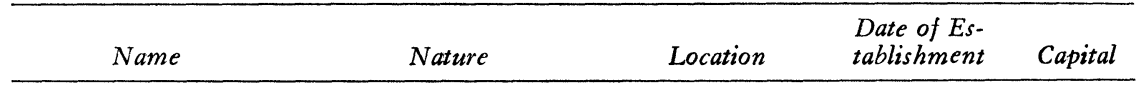

Factories Already Established

1. Chung Nan

Rubber Co. ${ }^{1}$

2. Overseas Chinese Enterprise Co. ${ }^{2}$

3. Tzuchung Sugar $\mathrm{Co}^{3}$

4. Nan-yang Brothers Tobacco Co.

5. Hua Hsi Land Development $\mathrm{Co}^{4}$

6. Overseas Chinese Western Development Co.

7. Hong Kong Overseas Chinese Co.

8. K'aiyuan Crockery Co.

9. Northwest Overseas Chinese Co. ${ }^{5}$

10. Overseas Chinese Land Development Co.

Tire repairing

Development of iron, tin, coal

Sugar refining

Cigarette manufacturing

Land development

Development of transportation \& communications

Development of mining industry

Earthenware manufacturing

?

? facturing

12. The Bank of Construction $^{\tau}$

13. Overseas Chinese Bank of Development $^{8}$

Development of the Southwest region

Development of domestic industries

$\begin{array}{ll}\text { 14. Fukien Overseas } & \text { Investment \& loan } \\ \text { Construction Co. }^{9} & \text { for transportation, }\end{array}$ mining, agriculture, and irrigation
Chungking

1939

Chungking

1940

33,000 as

Chungking

1941

50 million

Chungking, $\begin{array}{lll}\text { Kunming, } & \text { Apr. } 4, & \\ \text { Kueiyang } & 1940 & 1 \text { million }\end{array}$ Chungking 1941,10 million Tzuchung, 2 million

Chungking $1940 \quad 10$ million

Sikang

1939 3 million

Kueiyang, Chungking ? ? ? ? of Feb. '41 Chungking $1941 \quad 100$ million Chungking $1941 \quad 50$ million 


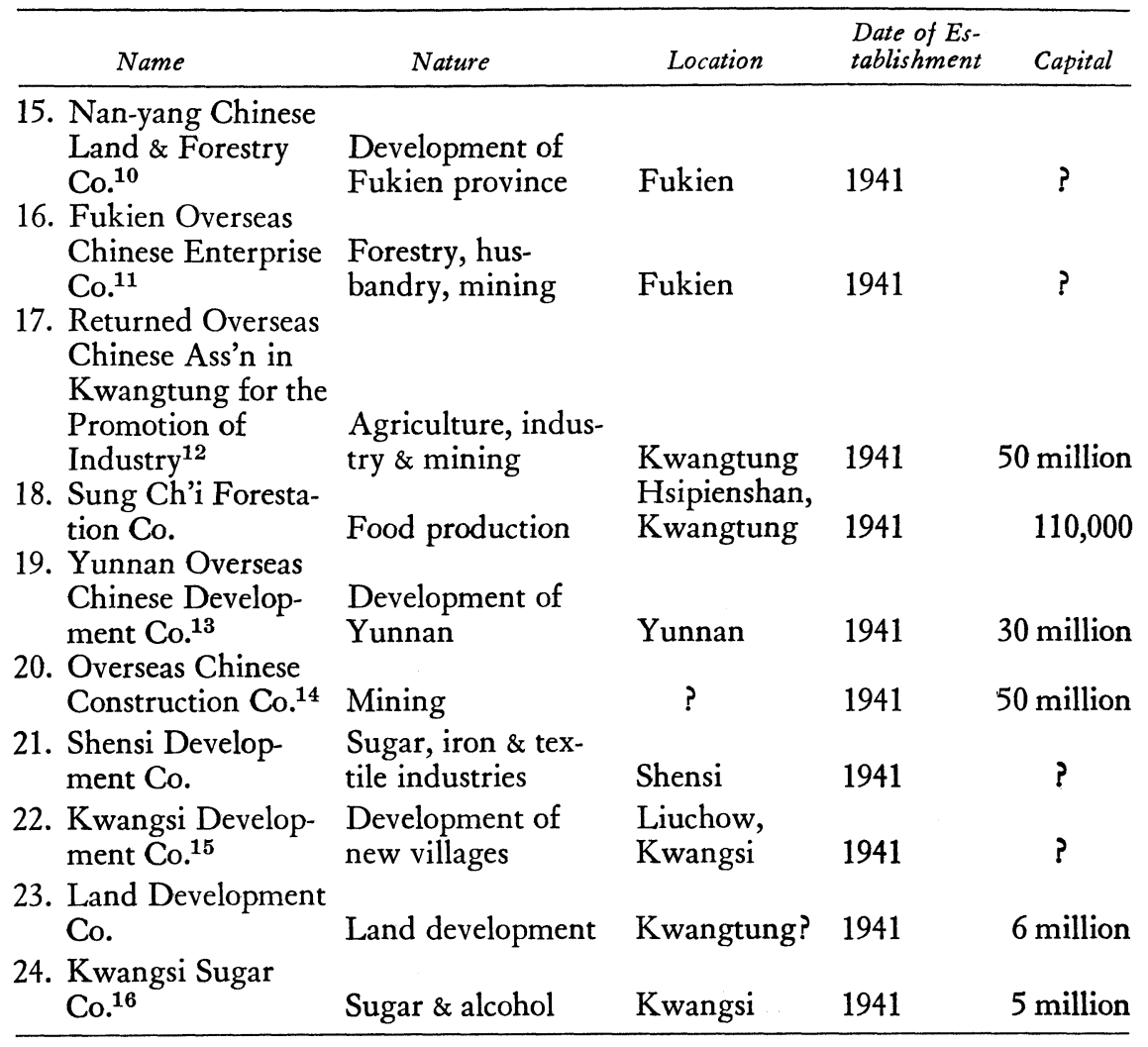

${ }^{1}$ Penang Chinese invested 700,000 yuan. Three more were being planned at Liuchow, Siakwan, and Shaoyun.

${ }^{2} \mathrm{Aw}$ Boon Haw invested 4.5 million yuan, and he and Alfonso Sycip Hsueh Fen-shih served on the board of trustees.

${ }^{3} \mathrm{Aw}$ Boon Haw served as the treasurer.

${ }^{4}$ Ch'en Shu-ming, Tan Kah Kee, Tjong See-gan, Chu Chi-hsing, Co Yu-ch'ao, and Lee Chim Tian helped organize the company together with Lung Yun and Huang Hsiu-feng, influential figures in Northwestern China.

${ }^{5}$ Filipino-Chinese bought 1,646 shares of the stock.

${ }^{6}$ Tan Kah Kee sponsored the founding of the company.

${ }^{7}$ Filipino-Chinese and other Nanyang Chinese were participating.

${ }^{8}$ The Overseas Chinese Bank in Singapore and the Chung Hsing Bank in Manila invested in the company.

${ }^{9} \mathrm{Aw}$ Boon Haw was a co-sponsor.

${ }^{10}$ Malacca Chinese were reported to have already established the company.

${ }^{11}$ Tan Kah Kee was organizing the company.

${ }_{12}$ Plans were laid out to sell the stock in the Philippines.

${ }^{13}$ Aw Boon Haw invested 10 million yuan.

${ }^{14}$ Plans were laid out to sell 40 million shares of the stock to Chinese in Southeast Asia and in the United States.

${ }^{15}$ Hong Kong Chinese from Kwangtung province were organizing the company.

${ }^{16}$ Nan-yang Company in Singapore was participating.

Sources: Hong Kong Ta Kung Pao, April 15, May 21, 25, June 10, September 15, 17, 1940, April 16, 1941; Ta Kung Pao, October 26, 1940, February 5, 1941; Ta Wan Pao, June 
7, 1940; Chien Kuo Pao, April 20, November 2, 1941; Chung Mei Jih Pao, June 3, 1941; Hsing Tao Jih Pao, December 4, 1941; Sheng Pao, January 1, 18, 1940; Cheng Yen Pao, October 21, 1940, February 1, March 25, 1941; Finance and Commerce, May 14, 1941; The Central Bank of China Bulletin VII, Spring (November 1, 1941); all cited in Mantetsu Chōsabu, Senji Shina keizai, pp. 75-89. Huang, Hua-ch'iao tui tsu kuo ti kung hsien, p. 136; "Seinan kaihatsu to shinko kigyo," Mantetsu chōsa geppö XX, No. 4 (April, 1940), pp. 123-146; Katayama Yasuni, "Jūkei seifu no senji kōkogyō seisaku," Mantetsu chōsa geppō XX, No. 12 (December, 1940), pp. 149-230; Imura, Rekkoku no tai-Shi tōshi, p. 204; Nami Shūdan Shireibu, Kakyō sōkin kingaku no hyōka, pp. 49-50; Meng, China Quarterly, IV, No. 4, p. 686. Wu, China Quarterly, V, No. 4, p. 629; Nanyö XXII, XXVII, Nos. 2, 6 (February, 1939, June, 1941), pp. 129-130; 35, 71-72; and Straits Budget. December 26, 1940.

From Table 8, it is clear that most of the factories were established after 1940, when the economy of Southeast Asia, particularly of Malaya, prospered and inflation was rampaging, and that the investment was concentrated on land development. Furthermore, several of these overseas Chinese-financed companies (the Overseas Chinese Enterprise Co., the Hua Hsi Land Development Co., the Bank of Construction, and the Overseas Chinese Land Development) were joint operations with conservative financial tycoons, militarists, and bureaucrat-capitalists, who had a substantial financial interest in them. ${ }^{80}$ The situation was, however, as the Mantetsu study concludes, unique in that overseas Chinese capital had united with the technological resources of the Chinese people in the hinterland. In this respect, the overseas Chinese capital investment was the "most promising venture and the backbone of China's hinterland economic development." 11 On the other hand, not all of these companies were in full operation by December, 1941. From information available, only the Chung Nan Rubber Company, the Tzuchung Sugar Company, and the Hua Hsi Land Development Company, in addition to a few others, were known to have started their operation by the time the Pacific War broke out. With the opening of hostilities in Southeast Asia and the subsequent Japanese occupation of the South Seas region, it is assumed that most of those in the planning stages were abandoned. In conclusion, the record of the investment commitment and planning was impressive; in actuality, the campaign for overseas Chinese investment in China's hinterland industries was not as rewarding as has been reported. ${ }^{82}$

\section{The Economic Effectiveness of the Boycott Movement}

The object of this analysis is to measure the effectiveness of the boycott, whose purposes were to inflict damages upon Japan's economy by severing business relations with the Japanese and by shutting out 
Japanese goods and to help develop China's industry through the purchase of its produce. To achieve these goals, as has been shown, the Nanyang Chinese stopped buying and using Japanese commodities, refused to load and unload goods going to or arriving from Japan, severed business relations with Japanese firms and banks, refused to patronize Japanese stores, and walked off their jobs in Japaneseoperated companies. The present discussion, however, is concerned mainly with the effectiveness of the boycott upon Japan's trade position, as it appears in statistics.

To follow the course of the boycott and analyze its effectiveness, it is useful to represent figures with relatives or indexes. These relatives and link relatives show the situation year to year, taking the earlier year as 100. Relatives and link relatives are shown for the total exports of Japan to each country in Southeast Asia. In Table 9 the material is presented in such a way as to illustrate the method of the comparison. $^{83}$

TABLE 9

Japanese Export Trade to Southeast Asian Countries, 1936-1941 Showing Relatives and Link Relatives

\begin{tabular}{|c|c|c|c|c|}
\hline & & $\begin{array}{l}\text { Millions } \\
\text { of Yen }\end{array}$ & Relatives & $\begin{array}{c}\text { Link } \\
\text { Relatives }\end{array}$ \\
\hline \multicolumn{5}{|c|}{ Malaya } \\
\hline 1936 & 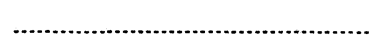 & 61.2 & 100.0 & \\
\hline 1937 & 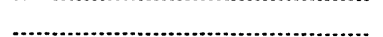 & 71.3 & 116.4 & 116.4 \\
\hline 1938 & 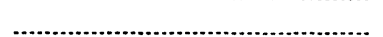 & 22.9 & 32.1 & 37.4 \\
\hline 1939 & 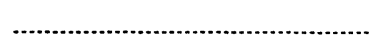 & 22.4 & 97.8 & 36.8 \\
\hline 1940 & - & $29.1^{*}$ & 47.6 & 130.0 \\
\hline 1941 & 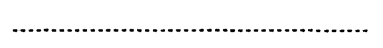 & $10.0 * *$ & 16.3 & 34.4 \\
\hline \multicolumn{5}{|c|}{ Dutch East Inides } \\
\hline 1936 & 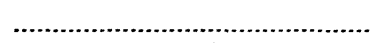 & 129.5 & 100.0 & \\
\hline 1937 & - & 200.9 & 155.2 & 155.2 \\
\hline 1938 & 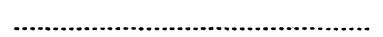 & 104.0 & 80.3 & 51.7 \\
\hline 1939 & -1.-1) & 137.8 & 105.6 & 106.8 \\
\hline 1940 & 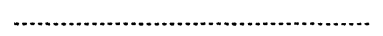 & 173.4 & 133.9 & 125.7 \\
\hline 1941 & 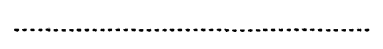 & 161.0 & 124.3 & 92.8 \\
\hline \multicolumn{5}{|c|}{ Philippines } \\
\hline 1936 & 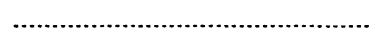 & 51.8 & 100.0 & \\
\hline 1937 & 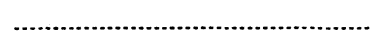 & 60.3 & 106.4 & 106.4 \\
\hline 1938 & . & 32.6 & 54.0 & 62.9 \\
\hline 1939 & - & 24.7 & 72.6 & 47.5 \\
\hline 1940 & 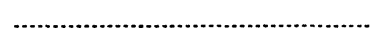 & 26.7 & 51.5 & 108.0 \\
\hline 1941 & 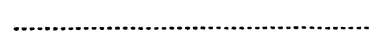 & 13.3 & 25.6 & 49.0 \\
\hline
\end{tabular}


TABLE 9 (concluded)

\begin{tabular}{|c|c|c|c|c|}
\hline & & $\begin{array}{l}\text { Millions } \\
\text { of Yen }\end{array}$ & Relatives & $\begin{array}{c}\text { Link } \\
\text { Relatives }\end{array}$ \\
\hline \multicolumn{5}{|c|}{ Thailand } \\
\hline 1936 & ...................... & 43.0 & 100.0 & \\
\hline 1937 & 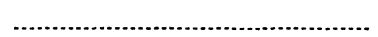 & 49.3 & 114.7 & 114.7 \\
\hline 1938 & 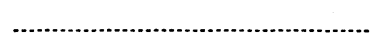 & 39.9 & 80.0 & 90.0 \\
\hline 1939 & 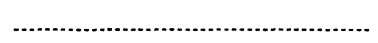 & 26.0 & 60.5 & 66.2 \\
\hline 1940 & 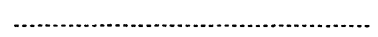 & 49.3 & 114.7 & 189.6 \\
\hline 1941 & 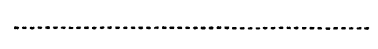 & 55.8 & 129.2 & 113.4 \\
\hline \multicolumn{5}{|c|}{ FrENCH INDOCHINA } \\
\hline 1936 & 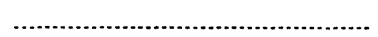 & 4.7 & 100.0 & \\
\hline 1937 & 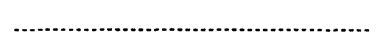 & 4.6 & 95.7 & 95.7 \\
\hline 1938 & - & 3.1 & 67.3 & 65.9 \\
\hline 1939 & 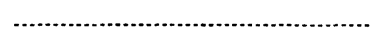 & 2.0 & 70.9 & 46.8 \\
\hline 1940 & 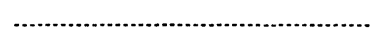 & 2.6 & 55.3 & 130.0 \\
\hline 1941 & 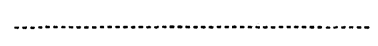 & 45.4 & 965.9 & 1746.0 \\
\hline \multicolumn{5}{|c|}{ TотаL } \\
\hline 1936 & ............. & 290.8 & 100.0 & \\
\hline 1937 & 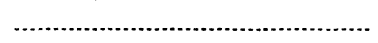 & 386.7 & 133.0 & 133.0 \\
\hline 1938 & 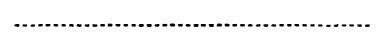 & 219.2 & 75.4 & 56.7 \\
\hline 1939 & 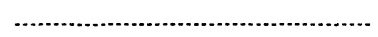 & 235.5 & 80.0 & 107.4 \\
\hline 1940 & 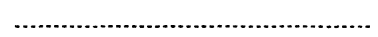 & 281.1 & 96.6 & 119.0 \\
\hline 1941 & 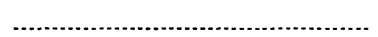 & $285.5^{* *}$ & 98.0 & 101.6 \\
\hline
\end{tabular}

* Converted to yen from the 1940 figure (SS $\$ 14.4$ million). The official exchange rate was: one SS dollar to 2.02 yen.

** These figures include only the Straits Settlements area.

Sources: Japan Ministry of Finance, The Annual Return of the Foreign Trade of Japan, 1936 to 1940; Statistical Department of Straits Settlements and Federation of Malayan States, Malayan Yearbook 1936-1940; Gouvernement general de I'Indochine, Direction des services economiques, Annuaire statistiques de l'Indochine, 1936-1940; Thailand, Customs Department, Annual Statement of the Foreign Trade and Navigation of the Kingdom of Thailand, 19361940; Philippines, Department of Overseas Trade, Official Annual Report of Insular Collector of Customs, 1936-1940; Japan, Statistical Bureau of the Prime Minister's Office, Japan Statistical Year Book, 1949.

In 1937, Japan's exports to the South Seas countries, measured in yen, increased 33 per cent over those of 1936, but in 1938, they declined sharply in every country. In 1939, the effectiveness of the boycott drive was still evident everywhere save the Dutch East Indies, where Japan's exports increased beyond the pre-boycott level of 1936. In 1939, her exports to Nanyang countries began to climb slightly and the trend continued until 1941. The protracted boycott appears to have had a telling effect on the Chinese, an effect which reflected the difficulties of enforcing it for such a long time. In 1940, Japanese ex- 
ports increased by 19 per cent over the 1939 total, reaching very close to the 1936 level. But they were far short of the 1937 figure, the best record between 1936 and 1941. In view of the fact that the Chinese were still boycotting Japanese goods, this slow recovery could be attributed in part to the boycott drive. In 1941, exports increased only 1.6 per cent over the 1940 record, although Japan's exports had almost regained the level of 1936-just 2 per cent below the 1936 figure. The slow recovery rate of 1941 appears to be owing not so much to the boycott as to such non-boycott factors as trade restrictions imposed by Japan and Southeast Asian countries; the rise in Japanese labor costs; and the competition for markets, for example, Japanese and American competition for Philippine markets.

Let us look more closely at the statistics. In evaluating the increase in 1937, the year the Sino-Japanese war broke out, it is important to note that an organized boycott movement did not begin until October or even much later ${ }^{84}$ therefore, the increase for 1937 had little relation to the boycott. A boycott that started in October or thereafter came too late for its effects to be visible in the 1937 statistics. Nonetheless, there is enough evidence to permit evaluation of its effects in every country in the last quarter of $1937 .{ }^{85}$ To look for the evidence of the boycott, we must turn to 1938,1939, 1940, and 1941. A brief examination of Table 9 reveals a great relative decline in Japan's total exports to the Nanyang in 1938; her exports decreased 43.3 per cent from the 1937 total. In 1939, although her exports gained 7 per cent over the previous year, they were approximately 150 million yen less than those of 1937, the best trade year, or a 38 per cent reduction. In 1940 and 1941 the export figures show some gains, but they were about Y100 million under the 1937 record, or about 25 per cent less. An examination of the Japanese total export figures from 1937 to 1941 leads to the conclusion that the boycott resulted in a substantial reduction in Japanese export trade with Southeast Asia in 1938 and 1939. When one considers the non-boycott factors already discussed, the effect of the boycott on the 1940 and 1941 exports is, however, less than the figure 25 per cent seems to indicate.

Let us examine the figures country by country. In Malaya, the boycott had a devastating effect on Japan's export business in 1938, when it fell by 67.9 per cent. This boycott remained effective through 
1940, although in that year her exports increased 30 per cent over those of 1939. A sudden and sharp decrease in 1941 is a puzzle. From the present study, we know that there was no renewed and intensified boycotting in that year. The decrease (65.6 per cent compared with the 1940 figure) can be attributed largely to various trade restrictions that Britain and Japan imposed on their trade. However, the Chinese boycott and the "Buy-Chinese-Products" campaign cannot be ignored in considering the fluctuation. Generally speaking, never had so effective a boycott been conducted for so long. Its effectiveness demonstrates the intensity of the boycott movement.

Japanese trade with the Dutch East Indies in 1938 showed a sharp reduction-about 50 per cent of the 1937 figure. This was remarkable because the Chinese worked under less favorable conditions in 1938. However, Japan's exports in 1939 and thereafter recovered the 1936 level, indicating that an organized boycott seems to have ended by the beginning of 1940. Although the 1940 and 1941 figures did not exceed the 1937 record, they must be considered a normal level of trade, considering other non-boycott factors.

In the Philippines, Japan's trade decrease was consistent from 1938 to 1940-an annual average of 50 per cent. It is difficult to separate the effect of the boycott from that of non-boycott factors, but the Chinese boycott no doubt contributed to the decline. The 1941 trade figure needs explanation. From this study we have learned that by the beginning of 1941, the Japanese no longer considered the Chinese boycott a serious threat to her trade with the Philippines. But American goods posed a new threat to Japanese trade with the Islands. Because of the quality and the competitive prices of American goods, Chinese merchants and consumers, both Chinese and Filipinos, appear to have flocked to them, thus contributing to a further decline in Japanese exports. As will be shown, the United States benefited most from the Chinese boycott.

In 1938, the boycott affected Thailand less than all the other Southeast Asian countries-a 10 per cent decline. Only in 1939, when the Communists added militancy, did the boycott show a contrasting effect. In that year, Japan's trade dropped 1.3 million yen, or a decline of 33.8 per cent. As we already know, in 1939, the Thai government crushed the Chinese National Salvation Movement with a series of police ac- 
tions which almost caused the Movement to disintegrate. The demise of the campaign was reflected in the 1940 statistic figure; Japan's 1940 trade with Thailand reached the level of the best trade year-1937. Thailand was the only country in which Japan's export trade recovered to the 1937 level. The 1940 and 1941 figures show that for all practical purposes the Chinese boycott drive had ceased, confirming the observation discussed in Chapter II.

The sharp decline in Japan's exports to French Indochina in 1938 and 1939 may not be attributable entirely to the boycott, because France maintained a stringent protectionist trade policy in her Far Eastern colony. Furthermore, the outbreak of war in Europe and the fall of France were significant to the decrease recorded in 1939 and 1940. The spectacular rise in the 1941 export figure can be explained by the fact that beginning in 1941, Japanese troops were stationed in French Indochina, requiring Japan to export to the colony goods and equipment for maintaining military logistics. The explanation seems to be supported by further evidence that in 1942, Japan's exports to French Indochina soared to 144 million yen because the colony had become the logistical base for Japanese military operations in Southeast Asia, and Saigon was the seat of the Japanese supreme command for the Southern area between November, 1941, and July, 1942. ${ }^{86}$

Economic conditions in Southeast Asia and Japan and the various countries' own trade policies were responsible for a decrease in Japanese export trade with the Nanyang countries. There was a steady decline in the prices of rubber, tin, sugar, and rice, the principal commodities of the region, until war started in Europe in September, 1939. Naturally the purchasing power of the natives dropped. Southeast Asian governments' enactment of a quota system for Japanese textiles and their erection of a high tariff wall hurt Japan's exports to the South Seas region. ${ }^{87}$ In addition, the Japanese government passed a trade regulatory act in September, 1937, under which the export of strategic materials and the import of non-strategic goods were prohibited. "It would be an exaggeration," one western observer stated, "to ascribe all of Japan's recent losses in Southeast Asia to the effect of the boycott campaign. Other factors have been at work, notably restrictions on raw material imports and rising costs of production in Japan, which have seriously hampered her export trade." 88 Nevertheless, we are 
bound to conclude that the Chinese boycott was generally effective in 1938 and 1939. So many other factors entered into the calculation of boycott effectiveness after 1940, that it is impossible to measure the effect of the boycott drive. It seems reasonable to argue that before 1940, the boycott was important in Japan's export trade with Southeast Asia but after 1940, its importance decreased.

A more precise method of studying the impact of the boycott is an examination of Japanese monthly export figures. The 1937-1939 period is selected for the purpose because the Chinese boycott was most intense in these years, ${ }^{89}$ and the Japanese government stopped the publication of monthly trade returns after 1939 for security reasons.

TAble 10

Value in Japanese Yen (Millions) of Goods Moving from Japan to Malaya, 1937-1939

\begin{tabular}{|c|c|c|c|}
\hline & 1937 & 1938 & 1939 \\
\hline January .............. & 4.7 & 1.2 & 1.0 \\
\hline February & 5.3 & 1.2 & 0.9 \\
\hline 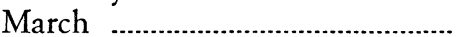 & 8.3 & 1.9 & 2.0 \\
\hline April & 7.1 & 1.8 & 1.6 \\
\hline May & 8.5 & 2.2 & 2.0 \\
\hline 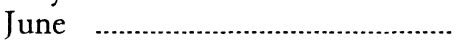 & 9.0 & 2.6 & 2.2 \\
\hline July & 8.8 & 2.0 & 1.8 \\
\hline August & 5.7 & 1.8 & 2.0 \\
\hline September & 4.3 & 2.1 & 2.0 \\
\hline October & 4.1 & 1.7 & 2.3 \\
\hline November & 3.2 & 2.1 & 2.0 \\
\hline December & 3.4 & 2.5 & 2.8 \\
\hline
\end{tabular}

Table 10 shows that Japan's exports started to fall in August, 1937, and continued to decline until they reached a low point in February, 1939. The effectiveness of the boycott drive in Malaya is shown by a comparison of the export average for the first six months in 1937, when there was no boycott, with those of 1938 and 1939. The overall monthly average for the first six months in 1937 was 7.2 million yen, and averages for the corresponding periods in 1938 and 1939 were 1.8 million yen and 1.6 million yen, respectively. In other words, Japan's exports in the first six months of 1938 and 1939 dropped to one-fourth of those in the corresponding period of 1937.

Table 10 also reveals an interesting fact about the response of the Malayan Chinese to those events of the war in China of particular con- 
cern to them. For instance, following each major Japanese victory-the fall of Nanking in December, 1937, the capitulation of Canton and Wuhan in October, 1938, and the defection of Wang Ching-wei in December, 1938-there was a sharp decrease in Japanese monthly exports, suggesting that Chinese intensified their boycott in each instance.

We turn to a brief examination of Japan's important export commodities to the British colony. Of twenty-eight main export items, all but a few suffered. Merchandise easily identifiable as Japanese proved the best targets for boycotting. Aquatic produce, mainly fish and its products consumed exclusively by the Chinese, sustained such a heavy damage that its market in Malaya was all but wiped out; statistics show its decline from 1.0 million yen to 29,000 yen. Other vulnerable goods were gelatine (285,913 yen to 129,576 yen); peppermint oil (156,524 yen to 1,164 yen); menthol crystals $(317,012$ yen to 10,667 yen); soap (317,191 yen to 96,365 yen); cotton textiles (12,220,544 yen to $5,450,841$ yen); cotton blankets (236,808 yen to 35,635 yen); hats (235,300 yen to 16,352 yen); paper $(654,068$ yen to 124,717 yen); chinaware $(1,174,468$ yen to 515,791 yen); lumber $(123,799$ yen to 103,841 yen); umbrellas (123,799 yen to 1,035 yen); lamps (597,255 yen to 113,277 yen); tires $(1,151,426$ yen to 41,814 yen); glassware $(1,356,943$ yen to 411,946 yen); and toys (631,132 yen to 214,489 yen). Since that merchandise was traditionally bought and sold by Chinese wholesalers and shopkeepers, it is safe to assume that the Chinese boycott drive was responsible for the cut.

Finally, we look at the shift in trade from the Japanese to the British and Chinese as a result of the boycott.

TABle 11

A Comparative Chart Showing a Shift in Malaya's Imports in Relation to Japan, Britain, and China

(Thousands)

\begin{tabular}{|c|c|c|c|c|}
\hline & & Japan & Britain & China \\
\hline 1936 & - & SS $\$ 32,546$ & SS $\$ 161,817$ & SS $\$ 22,966$ \\
\hline 1937 & ........ & 40,482 & 223,574 & 27,612 \\
\hline 1938 & 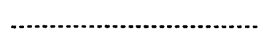 & 12,426 & 194,824 & 23,920 \\
\hline 1939 & 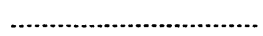 & 12,380 & 214,575 & 25,906 \\
\hline 1940 & 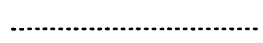 & 14,382 & 186,640 & 38,623 \\
\hline
\end{tabular}

Source: Malayan Yearbook, 1936, 1937, 1938, 1939, and 1940. 
This table makes it plain that Malaya's imports from Japan dwindled steadily until the end of 1940 . The decrease in 1940 as compared with the 1936 import figure was 56.1 per cent. On the other hand, Malaya's imports from China for 1940 increased 75 per cent over those in 1936. The steady increase in her imports from China since 1938 can be attributed partially to a "Buy-Chinese-Products" campaign which was conducted along with the boycott. Also noticeable in the table is that Britain shared some gains from the Chinese boycott of Japanese goods, particularly in 1939. Since Britain was the principal supplier for her colony and many of her exports, especially cotton and textile goods, were in competition with Japanese export goods, it can be inferred that the Chinese turned to British products as substitutes for Japanese goods.

The Chinese boycott in the Dutch East Indies produced the mildest impact in Southeast Asia. Monthly export figures are in Table 12. From official quarterly trade statistics, we learn that the monthly average of Japan's exports to the Dutch colony in the first half of 1937 was 19.2 yen. $^{90}$ Averages for the comparable periods in 1938 and 1939, however, went down to 7.2 million yen and 9.2 million yen, respectively, or about a fifty per cent decrease. The recovery in Japanese exports

\section{TABle 12}

Value in Japanese Yen (Millions) of Goods Moving from Japan to the Dutch East Indies, 1937-1939

\begin{tabular}{|c|c|c|c|}
\hline & 1937 & 1938 & 1939 \\
\hline January & & 6.1 & 5.3 \\
\hline 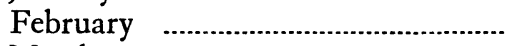 & & 6.3 & 7.0 \\
\hline March & & 6.3 & 10.5 \\
\hline April & & 8.6 & 8.9 \\
\hline 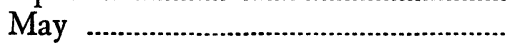 & & 7.9 & 12.3 \\
\hline 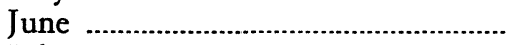 & & 8.0 & 11.2 \\
\hline 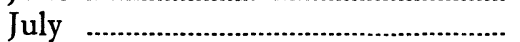 & 20.3 & 7.2 & 11.3 \\
\hline August & 14.8 & 9.8 & 12.2 \\
\hline 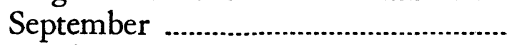 & 15.0 & 10.4 & 10.8 \\
\hline October & 13.3 & 11.2 & 13.2 \\
\hline November & 11.4 & 11.6 & 16.1 \\
\hline December ………-. & 10.0 & 11.5 & 19.1 \\
\hline
\end{tabular}

to the Dutch East Indies was quicker than it was in British Malaya, and, as a matter of fact, the Dutch East Indies was the only country wherein Japan's monthly export figure returned to the pre-boycott level 
as early as December, 1939. As in British Malaya, the most effective period of the boycott was the first six months of 1938; thereafter, monthly figures inched back to normalcy. It shows that a protracted boycott had its own built-in limitation for endurance, particularly in such a country as the Dutch Indies, where authorities were less acquiescent and tolerant toward the politically motivated boycott and where the Chinese were a tiny minority depending upon an overwhelming number of native consumers for a livelihood. Despite the severity of the boycott, its overall effect was, as it was expected, the mildest in all Southeast Asian countries. The fall of Nanking came at a time when the boycott was about to reach its peak, producing a sharp change in the trade figure (a drop from 10.0 to 6.1). Wang Ching-wei's defection in December, 1938, caused a similarly sharp reduction for the following two months. However, such events as the landing of the Japanese troops on Hainan Island (February, 1939) and at Amoy (May, 1939), and Wang Ching-wei's severance of relations with Chiang Kai-shek (July, 1939) produced no visible change in Japan's exports to the Dutch colony. The absence of response to these events reconfirms an earlier assertion that an organized Chinese boycott in the Netherland Indies was coming to an end in late 1939. It was also indicative of the attitude of the Indies-Chinese, most of whom were local-born and were oriented to Indonesia rather than to China.

Grains, foodstuffs, leather and leather products, oils and fats, cotton tissues, metal and metal goods, and finished machinery proved sensitive to boycotting. Each one of these items showed a decrease of about one-half or more of the 1937 figures.

Until 1937, Japan had been the principal trade partner of the Dutch East Indies, followed by the colony's mother country, as shown in Table 13. Japan's position was reversed in 1938, the year of the most severe boycott, when Holland became the principal supplier for her colony. In that year, Japan lost 52,652 Gd. in trade, a loss of 9.6 per cent in import percentage in the colony's total imports. Neither the Netherlands nor China reaped the benefits from the Japanese loss because the East Indies' imports from the motherland increased only $12,280 \mathrm{Gd}$., or 3.1 per cent, and China did not even share the benefits from the trade shift, as the decrease in imports from China (476 Gd., or 0.1 per cent decline) proves. In 1939, imports from Holland dropped 6,899 
TABLE 13

A Comparative Chart Showing a Shift in the Dutch East Indies' Imports in Relation to Japan, the Netherlands, and China

(Thousands)

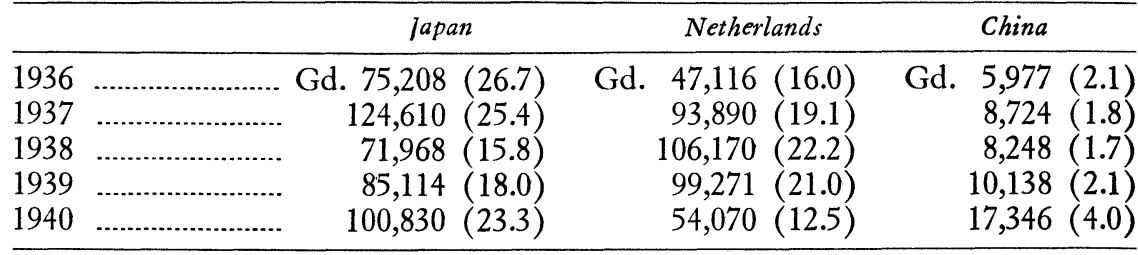

Sources: Indisch Verslag, cited in Fukuda, Nanyō kakyō kō-Nichi undō, p. 411. Cf. Nippon Bōeki Kenkyujō, ed. Daitōa köeki kihon tōkei. Figures in brackets indicate import percentage in relation to total imports.

Gd. under the 1938 total figure; the East Indies' percentage of imports from Holland in relation to the colony's total imports dropped also. On the other hand, Japan, still the second trade partner, increased her exports, gaining 13,146 Gd. and 2.2 per cent in the East Indies' imports relative to the colony's total imports. Only in 1939 and 1940 did the imports from China increase, not so much the result of the "Buy-ChinaProducts" campaign as of the outbreak of war in Europe and Holland's capitulation to Germany. The increase in imports from China, therefore, was at the expense of the Netherlands, not Japan. Yet, there was a boycott throughout the archipelagoes in 1939 and 1940, and it annoyed the Japanese, as has been observed. Some increase in imports from China may have been due to the "Buy-China-Products" campaign, but China and her compatriots in the Dutch colony were unable to promote the "Buy-Chinese-Products" campaign as effectively as in British Malaya.

An earlier examination of the Chinese boycott movement in the Philippines disclosed that it was one of the best disciplined and wellorganized movements. Trade statistics support this observation, as shown in Table 14.

No appreciable decrease was detected in 1937, mainly because the anti-Japanese movement, with its systematic boycott drive, did not start until late February, 1938. Another interesting fact is that the second half of each of the years in the study shows a steady increase in imports from Japan, followed by a decrease. This pattern may be explained by the fact that the Philippines is the only Christian country in Southeast Asia that observes Christmas and then the Chinese New 


\section{TABLe 14}

Value in Japanese Yen (Millions) of Goods Moving from Japan to the Philippines, 1937-1939

\begin{tabular}{|c|c|c|c|}
\hline & 1937 & 1938 & 1939 \\
\hline January ........ & & 3.4 & 1.5 \\
\hline 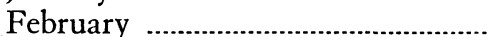 & & 3.9 & 1.8 \\
\hline March & & 3.2 & 1.9 \\
\hline April & & 3.8 & 2.2 \\
\hline May & & 2.7 & 2.1 \\
\hline June & & 2.5 & 2.1 \\
\hline July & 4.7 & 1.9 & 1.9 \\
\hline August & 4.9 & 1.8 & 1.7 \\
\hline September & 5.2 & 1.8 & 1.8 \\
\hline October & 5.4 & 2.2 & 2.6 \\
\hline November & 5.4 & 2.6 & 2.5 \\
\hline December & 4.9 & 2.8 & 2.8 \\
\hline
\end{tabular}

Year and a unique celebration of Semana Santa. Chinese merchants must have attempted to stock Japanese goods for these religious holidays despite the boycott. The consistency of the pattern of statistical fluctuation tends to support the Japanese observation. ${ }^{91}$ A comparison of the second half of 1937, when there was no organized boycott, with the corresponding periods of 1938 and 1939 reveals that Japan's exports to the Islands in 1938 and 1939 were cut to one-half of the 1937 average. The fall of Nanking, before the boycott and in the midst of the buying for the holidays, and the fall of Canton and Wuhan, in late October, 1938, when Chinese merchants were beginning to stock goods for the year's end and the New Year holidays, did not produce a significant drop in Japanese exports, as they did in Malaya. In contrast, the landings of the Japanese troops at Amoy and the subsequent seizure of the city had some effect because about 80 per cent of the Filipino-Chinese emigrated from Fukien province, in which Amoy is located. The fluctuation following Wang Ching-wei's defection and his announcement of his severing of relations with the Chungking government suggests that these major events, in addition to the promulgation of Regulations Governing the Purge and Registration of Enemy Goods (May, 1939), may have had something to do with the decrease.

Cotton was a commodity of first importance among Japanese exports to the Philippines. The decline in the export of this product was extremely sharp, a drop of 4.4 million pesos in the three years from 
1938 through $19400^{92}$ The decrease can be partly attributed to the rising cost of cotton products in Japan, which made it harder for Japan to compete with finer American cotton goods. ${ }^{93}$ Other export articles which showed a drastic decline were silk and rayon (3,605 pesos to 723 pesos); iron products (3,116,000 pesos to 246,000 pesos); sea food (2,149,000 pesos to 354,000 pesos); vegetables $(959,000$ pesos to 254,000 pesos); and miscellaneous goods (7,361,000 pesos to 2,431,000 pesos).

In the Philippines, but not in the Dutch East Indies, substitutes for boycotted Japanese goods were available at comparable prices from the United States; therefore, Philippine imports from the United States increased substantially from 1938 through 1940, as shown in Table 15.

TABle 15

A Comparative Chart Showing a Shift in Philippines' Imports in Relation to Japan, the United States, and China

(millions)

\begin{tabular}{|c|c|c|c|c|}
\hline & & Japan & United States & China \\
\hline 1936 & $\theta$ & P26.5 & P123.7 & P5.4 \\
\hline 1937 & & 32.2 & 127.3 & 6.6 \\
\hline 1938 & ... & 25.4 & 181.6 & 6.1 \\
\hline 1939 & 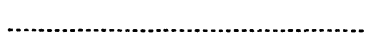 & 15.2 & 167.4 & 5.2 \\
\hline 1940 & 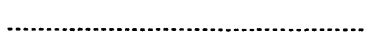 & 12.1 & 210.4 & 6.2 \\
\hline
\end{tabular}

Sources: Year Book of Philippine Statistics 1940. Daitōa kōeki kihon tōkei.

Japan lost a market of 20 million pesos, but the United States gained 83 million pesos between 1937 and 1940. Since China's gains in her exports to the Philippines in these years were almost nil, Chinese merchants turned to American goods as substitutes for boycotted Japanese goods. As a matter of fact, an official of the Japanese Chamber of Commerce in the Philippines suggested a 10 -to-30 per cent price reduction across the board for principal Japanese export goods in order to cope with the competitive prices of American products. ${ }^{94}$ The implication is that by the early spring of 1941, according to this study, the Chinese boycott was no longer a serious threat to Japanese trade in the Philippines. Instead, it was U.S. products that were undermining Japan's market in the Islands. With reduced prices, Chinese merchants, it was hoped, would switch back to Japanese goods because of a larger margin of profit. In the Philippines, a combination of the Chinese boycott, reportedly operating in 1941, but at a much reduced effective- 
ness; the availability of comparable or superior American products; and the rising cost of Japanese manufactured goods produced an economic situation detrimental to the Japanese export position. These conditions tended to help make the Chinese boycott drive more effective and durable than it had been. This peculiar situation was in contrast to the situation in the Netherlands Indies, where Chinese businessmen did not have such an option, since Holland and other European countries could not supply substitutes for Japanese articles. They were either involved in the European war or had been occupied by Germany.

Thailand, whose attitude toward the Chinese boycott movement was unsympathetic, provides a contrast between the objectives and the achievements of boycotting. The KMT-instigated Chinese anti-Japanese movement, lacking able leadership after 1938, was one of the more violent movements. Consequently, the sinews of the KMTorganized work were almost destroyed by repeated police actions at the end of 1940.

A glance at Table 16 shows that the boycott had a relatively mild effect in 1938. In Malaya and the Philippines, the boycott reduced Japanese exports by more than 50 per cent in the second half of 1938, compared with the corresponding period of 1937; in Thailand, the boycott cut Japanese exports by only 23 per cent in the second half of 1938. The inefficiency of the Thai-Chinese boycott is even clearer when the proportion of the Chinese population to the total population of Thailand and of the Philippines is compared. The total population of Thailand and of the Philippines was about the same in the late 1930's; the population of each was roughly 13 million. On the other hand, the Thai-Chinese population was 2.5 million, whereas the Filipino-Chinese population was only one-quarter of a million. The 250,000 FilipinoChinese produced a much more effective boycott result than the 2.5 million Thai-Chinese because of the skillful leadership and discipline provided by the Filipino-Chinese. It seems that the terrorism and murders that accompanied the Thai-Chinese boycott movement were indicative of its failure.

With this observation, let us look at monthly export figures. We do know that the Chinese started a systematic boycott in October, 1937, and that there was a well-established KMT organization until 1938. 
Despite the boycott and the KMT organization, the result of the boycott was not impressive in 1937 and 1938, as evidenced by the rises and falls of import figures and by a monthly average of Japan's exports, which was 3.6 million yen for 1937 and 3.2 million yen for 1938. Only in 1939 was the boycott effective (the monthly average dropped to 2.2

TABLe 16

Value of Japanese Yen (Millions) of Goods Moving from Japan to ThaIland, 1937-1939

\begin{tabular}{|c|c|c|c|}
\hline & 1937 & 1938 & 1939 \\
\hline January & & 2.5 & 1.9 \\
\hline 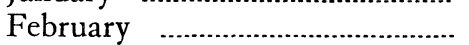 & & 1.9 & 2.7 \\
\hline 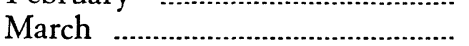 & & 2.5 & 3.2 \\
\hline April & & 2.7 & 1.8 \\
\hline May & & 4.9 & 1.9 \\
\hline June & & 7.2 & 1.6 \\
\hline July & 3.6 & 1.4 & 2.1 \\
\hline August & 2.8 & 6.2 & 2.0 \\
\hline September & 6.3 & 1.4 & 1.9 \\
\hline October & 2.8 & 2.2 & 1.8 \\
\hline 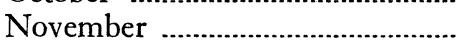 & 2.7 & 3.0 & 1.7 \\
\hline 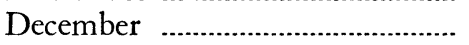 & 4.9 & 3.6 & 3.4 \\
\hline
\end{tabular}

million yen). We may attribute the decline to the Communists, who became active in the boycott movement, assuming increasingly the command of the anti-Japanese movement after late 1938. The militancy of the Communist-inspired boycott had a telling effect on Japanese exports in 1939, but, at the same time, it made the Thais indignant, and they retaliated with suppressive measures.

In summary, most of the Chinese in the Kingdom, patriotic as they were, appeared to be unable to organize an effective boycott campaign until 1939, partly because of their fear that such a movement would certainly provoke a hostile response from the Thais. The boycott was effective in 1939, though. Therefore, Skinner's remark that the boycott in 1937 and 1938 was "extremely effective," as quoted earlier, ${ }^{95}$ should be read with reservations.

Cotton textiles and their products, which constituted two-thirds of Thailand's imports from Japan, suffered very little from the boycott; Thailand imported cotton products valued at 17.9 million yen in 1937, 16.1 million yen in 1938, and 16.0 million yen in 1939. This phenomenon, despite the fact that cotton goods was elsewhere the item most 
vulnerable to the boycott, is attributable to Thailand's being a free market for cotton goods. ${ }^{96}$ Metal and allied products, however, virtually lost their market in Thailand in 1938-their exports dropped by 88 per cent. Their decline was as much attributable to the Chinese boycott as it was to Japan's trade regulations on these strategic materials. The decline in food (including aquatic products), paper, and china and glassware exports is ascribed solely to the Chinese boycott. Food exports dropped from 1.6 million yen in 1937 to 502,000 yen in 1939; paper, from 1.2 million yen to 50,000 yen; and china and glassware, from 1 million yen to 51,000 yen.

Table 17 shows a steady increase in imports from China and Britain and a decrease in imports from Japan. The rise in China's exports to Thailand attests to an effective campaign for Chinese to buy China's own products, such as metals and cotton cloth, which China could sell

TABLe 17

A Comparative Chart Showing a Shift in Thailand's Imports in Relation to Japan, Britain, and China

(millions)

\begin{tabular}{|c|c|c|c|}
\hline & Japan & Britain & China \\
\hline ......................... & Bt31.1 & Bt12.8 & Bt11.9 \\
\hline 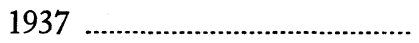 & 24.1 & 15.8 & 9.4 \\
\hline 1938 & 20.2 & 17.8 & 16.2 \\
\hline 1939 & 18.7 & 79.5 & 17.2 \\
\hline
\end{tabular}

Source: Annual Statement of the Foreign Trade and Navigation of the Kingdom of Thailand, 1936, 1937, 1938, 1939, and 1940.

at a lower price. ${ }^{97}$ In no other country in Southeast Asia did China compete so closely with Japan as in Thailand in 1938 and 1939. Britain also reaped a lion's share during the boycotting years, particularly in 1939. This is positive proof that the Chinese bought British goods as substitutes for Japanese commodities. It is doubtful, however, that Britain continued to be the principal supplier of Chinese needs in 1940, because of the end of the "phony" war in Europe.

Japan's trade with French Indochina had been insignificant because French policy was mercantilistic. On the other hand, French Indochina's trade relations with China had been particularly strong; China was second only to France itself in the quantity of trade with the colony, and Japan ranked fifth. Japan found it difficult, for instance, to 
export her cotton goods to French Indochina because of France's persistent protectionist policy. ${ }^{98}$

TABLe 18

Value in Japanese Yen (Thousands) of Goods Moving from Japan to French INDOCHINA, 1937-1939

\begin{tabular}{|c|c|c|c|}
\hline & 1937 & 1938 & 1939 \\
\hline 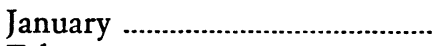 & & 223 & 150 \\
\hline February & & 254 & 131 \\
\hline March & & 400 & 281 \\
\hline April & & 241 & 168 \\
\hline 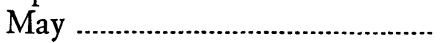 & & 279 & 174 \\
\hline 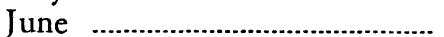 & & 372 & 199 \\
\hline July & 398 & 152 & 161 \\
\hline August & 328 & 159 & 161 \\
\hline September & 419 & 211 & 114 \\
\hline October & 295 & 279 & 185 \\
\hline November & 167 & 265 & 186 \\
\hline December & 445 & 318 & 269 \\
\hline
\end{tabular}

There was a slight decrease in Japan's exports to French Indochina in the second half of 1937. It is difficult to tell whether the boycott was responsible for the decline, but it is reasonable to assume that the antiJapanese movement was responsible to some degree since the boycott started in late August. In 1938, the effect of the boycott began to show in the statistics in French Indochina as in other countries. A sharp decrease in Japanese imports was recorded in July and August, coinciding with the Japanese bombings of Chinese cities in central and southern China. The defection of Wang Ching-wei and his arrival in Hanoi in December, 1938, might have had some effect on the low figures of January and February of 1939. Generally speaking, monthly figures for 1939 show some evidence of the boycott's effect, which was made even stronger by the acceleration of China's export trade with French Indochina and by a better exchange rate for the piaster as the Chinese yuan depreciated.

The "Buy-Chinese-Products" drive was successful, as Table 19 shows.

China's exports to French Indochina began to increase in 1937, and the 1940 total shows an increase of 55 per cent over the 1936 figure. Added to this increased trade were China's exports through Hong Kong. It is generally acknowledged that exports to French Indochina 
TABLE 19

A Comparative Chart Showing a Shift in French Indochina's Imports in Relation to Japan, France, China, and Hong Kong

(thousands)

\begin{tabular}{|c|c|c|c|c|}
\hline & Japan & France & China & Hong Kong \\
\hline 1936 & P 2,639 & P 52,042 & P 9,025 & P 7,164 \\
\hline 1937 ....................... & 3,997 & 85,555 & 11,450 & 13,541 \\
\hline 1938 & 4,250 & 136,518 & 14,299 & 16,617 \\
\hline 1939 & 2,552 & 113,011 & 11,592 & 16,617 \\
\hline 1940 & 2,965 & 67,592 & 14,067 & 25,806 \\
\hline
\end{tabular}

Source: Annuaire Statistique de l'Indochine, 1937, 1938, 1939, 1940.

from Hong Kong were of Chinese origin. ${ }^{99}$ China's exports through Hong Kong, beginning in 1937, sky-rocketed more than three and a half times over those of 1936; and in 1940, when France fell to Germany, China replaced France as the principal exporter. This rapid gain no doubt resulted in part from both a successful "Buy-ChineseProducts" campaign and the depreciation of the yuan. It is doubtful, however, whether China enjoyed favorable trade relations with French Indochina in 1941, because in late 1940, Japan's influence began to grow in the French colony. Japan's export decrease, beginning in $1939,{ }^{100}$ was the result of boycotting, Chinese patronage of home products, high tariff, and her own self-imposed trade restrictions.

Among principal import items from Japan, chinaware, silk tissue, and aquatic products-all easily identifiable as Japanese-were effectively boycotted. 


\section{Chapter IV}

\section{Summary and Conclusions}

The anti-Japanese National Salvation Movement from 1937 to 1941 was the most persistent, extensive, and intensified campaign that the Nanyang Chinese had waged against Japan since 1908, when they organized the first movement. Like similar movements in the past, that of 1937-1941 was largely the expression of the national consciousness of the Nanyang Chinese. Needless to say, their nationalism did not burst forth in 1937; it had begun to grow after the turn of the century when Japan defeated Imperial China in the 1894-95 SinoJapanese War and when the decadent Manchu government failed to transform China into a modern state through the 1898 Hundred Days of Reform. The successful Chinese Revolution in 1911 served the cause of Nanyang Chinese nationalism, but the subsequent history of Republican China disillusioned the Chinese abroad. Therefore, they responded with joy and pride when the reorganized KMT government unified China in 1927. After the KMT government had established its control over China, the regime, aware of a strong surge of nationalism among Nanyang Chinese, began to get seriously interested in them. On a practical level, the overseas Chinese, especially the Nanyang Chinese, whose remittances traditionally balanced China's budgetary deficits, were important to KMT China both as a principal source of revenue for her national treasury and as a vehicle for promoting her national interests.

For the next several years, the KMT government cemented ties with the overseas Chinese by passing a series of bills that strengthened its overseas Chinese program. At the same time, particularly after 1928, the Chinese government, through its overseas machinery, deliberately fostered the patriotism of the Nanyang Chinese with the San-Min-Chu-I. Also joined in this Tang-hua chiao-ÿ̈ movement were Chinese Chambers of Commerce, various associations, newspapers, and schools. The program succeeded in sharpening the Nanyang Chinese awareness of their fatherland's great culture and history, instilling in the compatriots a strong sense of being Chinese and of solidarity with China. In this context, the KMT's San-Min-Chu-I ideology became 
attractive to the Nanyang Chinese because it provided a set of ideas which expressed their nationalist views.

This KMT overseas program paid off handsomely, if it is measured by the support the KMT government received from the Nanyang Chinese during the 1928 and the 1931-32 National Salvation Movements, despite the Depression, and during the protracted 193741 movement.

The Nanyang Chinese viewed the Sino-Japanese War of 1937-41 as a grave threat to China's existence. It is noted that the National Salvation Movement, particularly the relief contribution campaign, was a spontaneous movement that spread quickly throughout Southeast Asia. Only after it was well underway did the KMT government provide advice and guidance. The initial responses of the Nanyang Chinese were similar; they pledged their loyalty to the Chinese government. Thereafter, various forms of the anti-Japanese and National Salvation Movement developed: contributions, bond subscriptions, boycotts, investment in China's industrial development, combat and non-combat service corps in China, and the "Buy-Chinese-Products" campaign. Nanyang Chinese resorted to every conceivable device, both legal and illegal, to help China's struggle for survival and impeded Japan's advance into Southeast Asia by disrupting her market there.

Whether the National Salvation Movement of 1937-41 was a success is a subjective judgment. The Japanese tended to minimize the achievements of the Movement and the effect of the boycott, accentuating, instead, difficulties of the Chinese in trying to carry out the campaign. On the other hand, the Chinese maximized their achievements, concealing internal factionalism and division that weakened their effectiveness. Obviously, the truth of the matter lies somewhere between the two claims. The preceding study shows that the Nanyang Chinese achieved some remarkable and tangible results. The money they poured into the coffers of the KMT government was a significant contribution to China's wartime financing. Not counting investments, remittances, and the value of material donations, revenue from relief contributions and bond subscriptions was estimated as 355 to 390 million yuan during the four-year period-a monthly average of seven million yuan. Besides, Nanyang Chinese remitted about five billion yuan to China during the same period. Contributions and remittances 
financed one-fourth of China's military expenditures during the first year of the hostilities. The Nanyang Chinese also boycotted Japanese goods a large part of the four years, producing a telling effect on Japanese trade with all the Southeast Asian countries, particularly in 1938 and 1939. These are graphic records of the achievements that few peoples, particularly minority groups, can match in either material contributions or tenacity.

The National Salvation Movement crystallized in the formation of the Nanyang Chinese Relief General Association, organized in October, 1938, at the height of national sentiment. Never before had the Chinese National Salvation Movement had a central organization to direct and coordinate its diversified activities. Never before had the Nanyang Chinese spoken in a single voice and acted as a body against the Japanese. The solidarity of the Nanyang Chinese, under NCRGA leadership, was nowhere more evident than in their reaction to the Wang Ching-wei government. They saw in that regime a threat to what they were working for-the emergence of a strong China.

It is this persistence in supporting China under Chiang Kai-shek that concerned the Japanese government. In hearings of the Budget Committee of the National Diet on February 4, 1941, Representative Tsurumi Yūsuke asked Foreign Minister Matsuoka Yōsuke how the government was planning to deal with the Nanyang Chinese, specifically to handle the problems of their monetary contributions to Chungking and of the obstacles they might place in the way of the Japanese. The government, Matsuoka admitted, had no feasible plan for dealing with that group who held the key to Japan's diplomatic adjustment with China. ${ }^{1}$ Implicit in his reply was the admission that the Japanese government, despite many attempts, had failed to alienate the Nanyang Chinese from the KMT government.

United as they were in opposing Japan, the Nanyang Chinese were not immune to dissension. Creating that dissension were clannishness, the Communists, the KMT's excessive interference, and the independence, as well as the self-interest, of the Chinese association.

The present study of the National Salvation Movement reveals the inherent clannishness within Chinese communities. This divisive force accentuated strains in the movement. As I have pointed out, the NCRGA and the National Salvation Movement were dominated by 
China-oriented Chinese who were, not surprisingly, China-born and China-educated. Because leaders of the NCRGA and the National Salvation Movement were China-born and China-educated and because they did not have political power under the local governments, they were strongly China-oriented. ${ }^{2}$ That West-oriented and educated local-born Chinese leaders were left out of the NCRGA leadership circles confirms the existence of a chasm between the China-oriented Chinese and the West-oriented Chinese. This division within Chinese communities was particularly marked in Singapore-Malaya, where there were both China-centered and British-centered loyalties. The existence of that divided loyalty was public knowledge; Tah Kah Kee complained that local-born Chinese did not contribute as much as China-born Chinese. A similar division existed in the Dutch Indies between the Sinkheh and the Baba.

The clannishness characteristic of Chinese communities was also evident in the exclusion of Hakkas. Except for two Cantonese Hakkas, Fukienese controlled the NCRGA. Throughout the four-year campaign there appears to have been no attempt to unify the Fukienese and the Cantonese. The rivalry between the Fukienese leader Tan Kah Kee and the Hakka leader Aw Boon Haw did not help solve the unity problem.

Not only clannishness but also the KMT-Communist power struggle undermined the united front. During the honeymoon period of the united front, the Communists succeeded in making inroads into the National Salvation Movement, and the non-Communists accepted them as patriots. After an armed clash-the New Fourth Army incident in 1941-the dissolution of the united front had serious repercussions on the National Salvation Movement. The renewed hostility was responsible for creating disunity among Filipino-Chinese leaders of the Resist-the-Enemy Committees. More seriously, Tan Kah Kee became disenchanted with the already graft-ridden KMT government because he was convinced that only through the united front could China hope to become a strong state.

Finally, the KMT's excessive interference made some powerful Nanyang Chinese leaders unhappy and created ill feelings among them. Although Nanyang Chinese leaders had consistently supported the KMT government against Japanese encroachment, they asserted 
their independence and resisted the KMT's attempts to control the National Salvation Movement. An example is the Manila Chamber of Commerce-KMT conflict. Chamber of Commerce leaders became irritated because KMT meddling forced them to start a boycott which they knew would be ineffective and would jeopardize their business position as well as the interests of the Chinese community. Though the boycott began, the Chamber of Commerce leaders did not like the way KMT activists had forced them to act. Consequently, they succeeded in ousting Tseng T'ing-chüan from the boycott committee. They did not wish to be controlled. The 1941 Tan Kah Kee affair was another result of KMT interference. Too impetuous and anxious to achieve objectives, KMT officials tried to coerce Nanyang Chinese into replacing Tan Kah Kee with someone more amenable to the KMT view. Wu T'ieh-ch'eng's and Kao Ling-pai's smear campaign to prevent Tan's re-election failed because the Nanyang Chinese did not want KMT control. That these attempts were not successful proves that the Chamber of Commerce and Nanyang Chinese leaders were not stooges of the KMT government in spite of its elaborate control system.

The KMT was not, however, the only organization that faced a control problem. The Chamber of Commerce had the same difficulty with its own affiliates. Traditionally, the power of the Chinese group rests upon the doctrine of responsibility; therefore, the group is accountable for the actions of its members. A corollary of this doctrine is the association's power to administer discipline and punishment to its members. The Chamber of Commerce, the most powerful organization, wields this power. As I have discussed, individual merchants and business associations did not always comply with directives of the Chamber of Commerce. The fact that the Chamber of Commerce had to apply pressure suggests that it did not have total control, contrary to a popularly accepted view that it controlled guild associations, and that Nanyang Chinese communities were a cohesive and unified society whose members were completely loyal to their associations which demanded such a commitment. Chinese merchants, like their parent organization, behaved in accordance with their self-interests.

This statement points out an important relationship between the effectiveness of the National Salvation Movement and that of Nanyang Chinese nationalism. Naturally, when the long range self- or business- 
interests of the Nanyang Chinese, particularly of the merchant class, coincided with the national interest of the KMT government, the National Salvation Movement became an effective vehicle of the Chamber of Commerce. The Nanyang Chinese generally believed that China under the KMT in the late 1930's was winning a place in the sun and serving their interests. They were aware of the benefits they could derive from a strong China. A powerful and united China would be able not only to supply Nanyang Chinese businessmen with goods to sell but also to protect the welfare of Chinese communities. The Nanyang Chinese realized that a Japan-dominated China would not, in the long run, safeguard their interests but would pose a local threat to their interests. A China dominated by Japan, then, would be incompatible with Nanyang Chinese self-interest. Taking the long view, the Nanyang Chinese cooperated with the KMT. They launched the National Salvation Movement because Japan was attempting to keep China divided and weak. In short, the Nanyang Chinese supported the KMT government not so much because the KMT and its ideology persuaded them as they expressed the nationalistic views of the Nanyang Chinese; rather, they recognized the KMT government as a useful political power for their ultimate interests. In the National Salvation Movement the common interest of the KMT and the Nanyang Chinese met on the level of national aspirations-the emergence of a strong China.

This conclusion seems to reinforce the view that the Nanyang Chinese supported the Chinese government, not the government of the KMT or the Communist Party. As I have pointed out, Tan Kah Kee stood for Pu-p'ien-pu-tang-the position Consul Kao denounced as anachronistic when he demanded that Tan and his followers commit themselves to absolute loyalty to the KMT government. Tan and many others supported the KMT because it would serve their future interests; for the same reason they supported the Communist regime in the postwar period. In this context, Tan Kah Kee's motives for sympathizing with the Chinese Communist Party become clearer. As he compared the discipline and frugality of the Communist regime with the corruption of the KMT government, Tan saw China's hope in a Chinese Communist government. His sympathy for the Communist Party, shown in 1940-1941, was therefore not ideological; it was 
the practical consideration of a man who had spent his lifetime in the cause of the emergence of a China which could protect the interest of Nanyang Chinese communities and which he and his compatriots could be proud of.

On the other hand, when the economic- or the self-interests of the Nanyang Chinese were not compatible with KMT political interests, the National Salvation Movement began to lose its effectiveness. The Nanyang Chinese had to keep their real and immediate problems in sight. Their realistic approach to these problems, arising from their dominant economic position among peoples generally hostile to them, appears to have motivated their actions. The behavior of the ThaiChinese leaders illustrates this point. Because of the surge of Thai nationalism, after early 1941, the Thai-Chinese main concern was economic survival, not an effective campaign for the National Salvation Movement. Although remaining loyal to China, they could not support the movement at the expense of their economic position or at the risk of their survival. In Thailand and, to a certain extent, in the Philippines and the Dutch East Indies, carrying out an effective National Salvation Movement would have spelled economic disaster for the Chinese. They depended upon Japanese goods for business and ultimately for their livelihood. They lacked the capital to endure a protracted boycott, which would not endear them to the natives, who were the principal consumers of boycotted Japanese merchandise. Needless to say, the local governments, for economic and political reasons, would not long tolerate the politically motivated National Salvation Movement. As I have shown, the Thai and Filipino governments used the Chinese boycott as a pretext to curb Chinese economic activities. The colonial authorities also suppressed the National Salvation Movement to maintain law and order and to avoid diplomatic complications with Japan.

The Chinese were usually in the uncomfortable position of being under pressure from both sides. The KMT and other groups urged them to boycott; local governments urged them not to boycott. They wanted to support China's cause, but they did not want to jeopardize their economic life and livelihood. It is therefore understandable that quite a few merchants defied boycott orders out of economic necessity and that they had to be coerced to continue anti-Japanese activities. 
Even the powerful machinery of the KMT government, well known as an organization given to attempting to guide other bodies, could not obtain from the Nanyang Chinese a total commitment to patriotism. The realistic Nanyang Chinese could not afford to forget their goaleconomic survival-which they had to attain with or without the KMT government. Although some interests of the Nanyang Chinese coincided with the national interests of the KMT government, others did not. That conflict of interests explains the behavior of the Nanyang Chinese. The Nanyang Chinese National Salvation Movement was not an example of total patriotism; the Nanyang Chinese, like other groups, could not be expected to be completely altruistic.

This self-interest, one suspects, explains both the decrease of enthusiasm as a result of the prolonged drive and the noticeable slackening of boycott and anti-Japanese activities when Japan emerged as a dominant Southeast Asian power in 1941. A general decline in the effectiveness of the National Salvation Movement may be attributed to Nanyang Chinese interest in protection and survival. The behavior of some business leaders indicated that they did not wish to get involved further in outright anti-Japanese activity when Japan's dominance was imminent in Southeast Asia. As I have discussed, the actions of Alfonso Sycip Hsueh Fen-shih of the Philippines, Chu Chi-hsing of Indochina, and Chang Lan-ch'en of Thailand are examples. Their conduct indicates that they realized that Japanese ascendency in Southeast Asia was inevitable. It would be, therefore, unwise and certainly suicidal, they seem to have concluded, to continue anti-Japanese activities and the boycott. Their survival instinct, developed by life as a minority group under adverse conditions, told them that further anti-Japanese resistance would only bring upon Chinese communities the wrath of the Japanese if the Japanese military should occupy Southeast Asian countries. By the early summer of 1941, some important segments of the Chinese community leadership appeared to share the view that Japanese occupation of the South Seas region was a probability. They knew that in a Japanese-occupied Southeast Asia, the Chinese would be the first target of a sook ching (purification by elimination)-exactly as did happen. The self-interest of the Nanyang Chinese compelled them to self-preservation, turning from their previous commitment to the KMT government, though many staunch Chinese took up 
arms against the Japanese. One should not judge this behavior too harshly. A Pacific war might have been a welcome relief to the Chungking government; it was a matter of life and death to the Nanyang Chinese. As one Chinese leader in Manila admitted, he would not be able to serve China if he died. As he said, Nanyang Chinese could serve China better by surviving a Japanese occupation. He believed that to survive, they should not provoke Japan but "modify [their] anti-Japanese stance." ${ }^{3}$ Still others cooperated or appeared to cooperate with the Japanese military not only during the occupation years but even before.

Yet the Nanyang Chinese carried on the National Salvation Movement for four years even though a prolonged anti-Japanese drive was foredoomed to failure. Nevertheless, they did so largely because they wished to see a strong China. Their anti-Japanese National Salvation Movement in its various forms was the only way the Nanyang Chinese knew in which the minority group could express its national feelings against Japan's injustice toward their fatherland.

It was a combination of patriotism and self-interest that compelled the Nanyang Chinese to plunge into the National Salvation Movement; the path was neither popular nor easy. As I have shown, the Nanyang Chinese had a great interest in political matters; they did not sit on the fence on the China issue because they had a great stake in it. The stereotyped characterization of the Nanyang Chinese as interested only in money-making, not in politics, and as maintaining a policy of non-involvement is just that-a stereotype with little truth in it. This study should dispel such accusations.

Japanese policy-makers seriously underestimated the latent national consciousness and aspirations of the Nanyang Chinese. They discounted, even with contempt, the ability of the Chinese to endure hardship and to sacrifice for China. Instead, the Japanese had an exaggerated view of the Chinese matter-of-fact business sense. Their failure to understand the Nanyang Chinese mentality cost them dearly. The Japanese occupation forces began their military administration with the distorted notion that the Chinese in Southeast Asia would become subservient to the Japanese military overlords and would cooperate once they had been cowed by initial shock treatment. Such a warped concept was reinforced by the animosity of the Japanese soldiers 
toward the Chinese, who harassed them in China and in the Southeast Asian military campaign, particularly in Malaya-Singapore and in the Philippines. ${ }^{4}$ At the beginning, Japanese administrators, military and civilian alike, had no policy for dealing with the Chinese other than vague, broad principles. For them, the Chinese were a milk cow to squeeze the milk from and were useful only for their "commercial talents." Though the policy changed later, the damage had been done. Their myopic policy belied the Japanese slogan proclaiming the equality of all races and spelled doom for the Japanese occupation in Southeast Asia. The legacies of this short-sighted policy were not easily erased or forgotten for many years. ${ }^{6}$ 


\section{Notes}

\section{Introduction}

1. H. F. MacNair, "Relations of China to Her Nationals Abroad," Chinese Social and Political Science Review, VIII (1923), p. 30.

2. Ta Chen, Emigrant Communities in South China. A Study of Overseas Chinese: Its Influence on the Standards of Living and Social Change, trans. (New York: Institute of Pacific Relations, 1940), pp. 49-51; H. F. MacNair, The Chinese Abroad; Their Position and Protection (Shanghai: Commercial Press, 1925), pp. 1-2.

3. Victor Purcell, The Chinese in Southeast Asia (London: Oxford University Press, 1951), p. 34; Fukuda Shōzō, et al., Nanyō kakyō kō-Nichi kyükoku undō no kenkyū (Tokyo: Tōa Kenkyūjo, 1945), p. 52. Hereafter, Fukuda, Nanyō kakyō kō-Nichi undō.

4. Edgar Wickberg, The Chinese in Philippine Life, 1850-1898 (New Haven, Conn.: Yale University Press, 1965), Chap. 8.

5. The 1717 edict allowed Chinese already abroad to return without facing punishment upon their arrival. The 1729 edict set a date after which they would not be allowed to return. Ta Chen, Emigrant Communities in South China, pp. 49-51.

6. This law code contained an article which stipulated capital punishment for those who were engaged in foreign trade or attempted to emigrate to foreign countries.

7. Ichikawa Kenjirō, "Chin ka ki to kakyō no seiji kikin," Töyō Gakuhō LI, No. 2 (September, 1968), pp. 5-7.

Sun Yat-sen visited Singapore in 1905, to hold revolutionary meetings and in 1908, he created "the Nanyang Department of the T'ung Meng Hui . . . in Singapore to coordinate revolutionary activities in South-East Asia." In the same year he founded the Yüeh shu pao she in Penang and Batavia. The Yüeh shu pao she was a reading society for the dissemination of Sun's revolutionary ideology and center of his movement in the South Seas region. Png Poh Seng, "The Kuomintang In Malay," Journal of Southeast Asian History (March, 1961) II, No. 1, pp. 6-9. Hereafter Png, JSAH.

Sun's remark, that the overseas Chinese were the "Mother of the Chinese Revolution," was apparently an afterthought.

8. Lea E. Williams, Overseas Chinese Nationalism. The Genesis of the Pan-Chinese Movement in Indonesia, 1900-1916 (Glencoe, Ill.: The Free Press, 1960), pp. 171, 174. In the Dutch Indies, Sun Yat-sen was “a remote figure.” By 1915, a contribution appeal conducted by his agents did not evoke an enthusiastic response.

9. For a discussion of boycotts, see C. F. Remer, A Study of Chinese Boycotts With Special Reference to Their Economic Effectiveness (Baltimore: The Johns Hopkins University Press, 1933); Nanyō oyobi Nipponjin Sha, Shingapōru wo chūshin ni dōbō katsuyaku Nanyō no 50-nen (Tokyo: Hokuto Shobō, 1938), p. 248.

10. For a detailed account of the 1919 anti-Japanese boycott movement, see my The Nanyang Chinese Anti-Japanese Boycott Movements, 1908-1928. A Study of Nanyang Chinese Nationalism, pp. 7-12. A paper read at the International Conference of Asian History, August, 1968, the University of Malaysia, Malaysia.

11. Tōa Kenkyūjo, Nanyō kakyō chōsa no kekka gaiyō (Tokyo: Tōa Kenkyūjo, 1941), p. 31. Cf. Chow Tse-tsung, The May Fourth Movement. Intellectual Movement in Modern China (Cambridge, Mass.: Harvard University Press, 1960).

12. Png, JSAH, p. 22.

13. Lin Chih-kuang and Chu Hua-yu, Nan-yang Hua-ch'iao chiao-yii tiao-ch'a yen-chiu, trans. (Tokyo: Tōa Kenkyūjo, 1940), p. 88. Mimeo.

14. Nanyang Siang Poh She, ed., Nan-yang nien-chien 1939 (Singapore: Nanyang Siang Poh She, 1939), Sec. V, p. 5. The Office later was re-named Overseas Chinese Affairs Commission.

15. Li Tsung-huang, ed., Chung-kuo Kuo-min-tang shih (Shanghai: Min chih shu ch'u, 1935), pp. 449-450.

16. Chung-kuo Kuo-min-tang chung-yang chih-hsing wei-yüan-hui, ed. Chung-kuo Kuomin-tang nien-chien 1934 (Nanking: KMT government, 1934), Sec. IV, p. 245.

It is of interest to note that the KMT gained greater strength in the three countries where the party was declared illegal or had restricted activities. Hereafer KMT, Chung-kuo Kuomin-tang nien-chien 1934.

17. Ch'iao-wu wei-yüan-hui mi-shu-ch'u, ed., Ch'iao-wu fa-kuei hui pien, trans. (Tokyo: Tōa Kenkyūjo, 1941), p. 546. Mimeo.

18. Fukuda, Nanyō kakyō kō-Nichi undō, pp. 69-70. 
19. KMT, Chung-kuo Kuo-min-tang nien-chien 1934, Sec. V, p. 1; Fukuda, Nanyö kakyō kō-Nichi undō, p. 72.

20. KMT, Chung-kuo Kuo-min-tang nien-chien 1934, Sec. V, p. 10; Fukuda, Nanyö kakyö kō-Nichi und̄o, pp. 73-83.

21. Fukuda, Nanyō kakyō kō-Nichi undō, pp. 162-177; Tsukimura Ichirō, "Nanyō kakyō shimbun ni kansuru ichi chōsa," Töa kenkyüjohō, No. 11 (August, 1941), pp. 124-125.

22. Fukuda, Nanyö kakyō kō-Nichi undō, pp. 77-78, 174.

23. Ibid., pp. 176-177; Tsukimura, Töa kenkyüjohō, No. 11, pp. 127-128.

24. Tsukimura, Tōa kenkyüjohō, No. 11, pp. 117-122.

The Nanyang Siang Poh was founded by Tan Kah Kee, the leader of the anti-Japanese movement, and it had been the mouthpiece of the Nanyang Chinese Relief General Association, the central agent of the Nanyang Chinese National Salvation Movement. The Sin Chew Jit Poh was owned by Aw Boon Haw, the Tiger Balm King. The Sin Po's editorial policy was SanMin-Chu-I. The Fookien Times's editor-in-chief was Go Puan-seng and the Chinese Commercial News' general manager was Yü I-t'ung. Go and Yü were intellectual leaders in the Manila Chinese community.

25. Ch'iao-wu wei-yüan-hui, Ch'iao-wu fa-kuei hui pien, pp. $502 \mathrm{ff}, 531$.

26. Ibid.; Fukuda, Nanyō kakyō kō-Nichi undō, p. 229.

27. Ta Chen, Emigrant Communities in South China, pp. 157-160; Nan-yang Hua-ch'iao chiao-ÿ̈ hui-i-pao (Shanghai, 1930), pp. 217, 245-246, cited in Fukuda, Nanyō kakyō kōNichi undō, pp. 108-109.

28. Fukuda, Nanyō kakyō kō-Nichi undō, p. 109; Lin and Chu, Nan-yang Hua-ch'iao chiao-ÿ̈, pp. 146-147.

29. Japan, Kikakuin, Kakyō no kenkyū (Tokyo: Shozambō, 1939), p. 87; Ta Chen, Emigrant Communities in South China, p. 160.

30. Ch'iao-wu wei-yüan-hui, Ch'iao-wu fa-kuei hui pien, pp. 344-346; Minami Manshū Tetsudō Tōa Keizai Chōsakyoku, Kakyō, Keizai shiryō XIII, No. 12 (Tokyo: Minami Manshū Tetsudō Tōa Keizai Chōsakyoku, 1927), pp. 192-193.

31. Ch'iao-wu wei-yüan-hui, Ch'iao-wu fa-kuei hui pien, pp. 344-346; Lin and Chu, Nanyang Hua-ch'iao chiao-yü, p. 133.

By 1937, the KMT government had established consular service at the following locations. Consulates General: Singapore, Hanoi, Manila, and Batavia. Consulates: Sandakan, Rangoon, Penang, Kuala Lumpur, Saigon, Surabaya, Palembang, Medan, and Makassar. Commercial Representative at Bangkok. Nan-yang nien-chien 1938, cited in Fukuda, Nanyō kakyō kō-Nichi undō, p. 86.

32. Tai Li died in an airline crash in 1946. Ch'en Li-fu was a member of the KMT Central Executive Committee and chairman of the KMT Organization Department. Ch'en Kuo-fu was a member of the Standing Committee of the KMT Central Executive Committee and a member of the KMT Political Committee.

33. Pan Pacific Monthly (November, 1929), p. 3, cited in Charles B. McLane, Soviet Strategies in Southeast Asia. An Exploration of Eastern Policy under Lenin and Stalin (Princeton, New Jersey: Princeton University Press, 1966) p. 134; Negri Sembilan Administration Report (1928), p. 19; FMS Chinese Protectorate's Report (1928), p. 3; W. L. Blyth, Chinese Labour in Malaya, cited in Png, JSAH, p. 31.

This observation is corroborated by Rene H. Onraet, former police chief in Singapore. He stated: "South Seas Communist Group, controlled by the Chinese Communist party, comprised the colonies of Great Britain, Holland, France, also Siam and Burma." Rene H. Onraet, Singapore-A Police Background (London: Dorothy Crip and Co., 1947), p. 112.

34. McLane, Soviet Strategies, pp. 132-133.

Already the Indonesian Communist Party had been organized, but it was crushed in the abortive 1927 coup. The South Seas General Labor Union was organized in 1926, and the Nanyang Communist Party was created in Singapore with the help of the Chinese.

35. J. H. Brimmel, Communism in South East Asia. A Political Analysis (London: Oxford University Press, 1959), p. 146; Ajia Kyökai, ed., Tōnan Ajia no ippan jōsei-Tokuni Kyōsanshugi seiryoku tono kanren ni oite (Tokyo: Ajia Kyōkai, 1957), p. 472.

Loi Tek was the Secretary General of the Malay Communist Party. The Japanese military police captured him in late February, 1942, in Singapore. He agreed to serve as a double agent for the Japanese in exchange for his life. Information Loi supplied to the Japanese police broke the sinews of the Party in Singapore and Malaya, culminating in a mass arresting and killing of most of ranking members of the Party, who gathered in Batu Caves, Selangor, in September, 1942. Harry Miller, The Communist Menace in Malaya (New York: Frederick A. Praeger, 1954), pp. 39-40. Miller's account is confirmed by my correspondence with a former Japanese military police commandant who arranged the deal with Loi. 
36. Rupert Emerson, "The Chinese in Malaysia," Pacific Affairs VIII (September, 1934), pp. 264, 268-269; Purcell, The Chinese in Southeast Asia, pp. 398-399; Png, JSAH, pp. 28-29.

Dato Tan Cheng Lock supported the Governor General's decision to enact the Aliens Ordinance in 1932, which aimed at curbing a subversive alien ideology, specifically the KMT. Png, however, adds that "Tan Cheng Lock was speaking as a Straits-born Chinese."

37. Emerson, Pacific Affairs VIII, p. 260.

\section{Chapter I}

1. Bode (Jakarta), October 11, 1937, cited in Minami Manshū Tetsudō Tōa Keizai Chōsakyoku, Ranryō Indo ni okeru kakyō, Nanyō kakyō sōsho IV (Tokyo: Minami Manshū Tetsudo Tōa Keizai Chōsakyoku, 1940), pp. 399-400. Hereafter Mantetsu TKC, NKS IV. 121.

2. Japan, Gaimushō Nanyōka, Kakyō kenkyū shiryō (Tokyo: Gaimushō, 1942-1943), p.

3. Purcell, The Chinese in Southeast Asia, p. 364; Png. JSAH, p. 35: Japan, Gaimushō Tsūshōkyoku, Shina Jihen to tai-Nichi boikotto mondai (Tokyo: Gaimushō, 1938), pp. 64-76. Marked "Secret." Mimeo.

4. Japan, [Takumushō]? Takumukyoku Nanyōka, Shina Jihen ka ni okeru Nanyö no dōkō to sono eikyō (Tokyo: Takumushō, 1938), n.p. Marked "Secret." Mimeo.

5. Japan, Gaimushō Jōhōbu Dai Sanbu, Nanyō kakyō mondai (Tokyo: Gaimushō, 1938), p. 89. Marked "Top Secret." Hereafter, Japan, Gaimushō Jōhōbu, Nanyō kakyō mondai.

6. The negotiations between Hidaka Shinrokurō, Counsellor of the Japanese Embassy at Nanking, and Kao Tsung-wu, head of the Asiatic Department of the Ministry of Foreign Affairs, and Gen. Chang Ch'ün, were underway on July 18, and were reported to be near settlement. F. C. Jones, Japan's New Order in East Asia 1937-1945 (London: Oxford University Press, 1954), pp. 36-37.

7. Ibid., p. 38

8. Straits Times (Singapore), July 24, 1937 cited in Töa jōhō, No. 256 (August 15, 1937), p. 17.

9. Japan, Takumushō, Takumukyoku Nanyōka, Shina jihen ka ni okeru Nanyō kakyō, n.p.; Japan, Taiwan Sōtokufu Kambō Gaijibu, Nanyō kakyō jijō (Taihoku, Taiwan: Taiwan Sōtokufu, 1943), p. 82. Hereafter, Japan, TSKG, Nanyō kakyō jijō; Japan, Gaimushō Jōhōbu, Nanyō kakyō mondai, p. 89; Töa X, No. 9 (September, 1937), pp. 73-74.

10. Consul General Gunji (Singapore) to Foreign Minister Hirota, August 7, 1937; Japan, Gaimushō Jōhōbu, Nanyō kakyō mondai, pp. 90-91; Nanyō Kyōkai, Nampō keizai kondankaì hökokusho (1940), p. 52. Marked "Secret." This is the minutes of the conference; Nanyo XXIII, No. 11 (November, 1937), pp. 99.

11. Japan, Gaimushō Jōhōbu, Nanyō kakyō mondai, p. 90.

12. Consul General Gunji to Foreign Minister Hirota, August 6, 1937; Straits Times, August $4,1937$.

13. Fukuda, Nanyō kakyō kō-Nichi undō, p. 292.

14. Yushitsu Jitensha, No. 4, cited in Nanyó XXIII, No. 11, p. 105.

15. Nanyō Kyōkai Shingapōru Shōhin chinretsu-shitsu tsūshin, August 18, 1937. Hereafter, Nankyō tsūshin.

The Nanyō Kyōkai was a Japanese government-subsidized organization operating ostensibly for gathering and disseminating trade information. Part of its activities involved gathering intelligence reports for the Japanese military. Its trade office, together with other Japanese offices, was investigated on January 18, 1939, by the Singapore police authorities, which summoned a few Japanese for questioning and confiscated papers from these offices. Kanan Ginkō Shingapōru shiten, "Han-Nichi to Shingapōru," Jikyokujōhō, No. 17 (January 31, 1939), pp. 6-7, in Marei jijō, n.d. Mimeo.

In Johore, on October 3, two Chinese stabbed a Japanese photo shop owner. Japan, Gaimushō Jōhōbu, Nanyō kakyō mondai, p. 92.

16. Japan, Gaimushō Jöhōbu, Nanyō kakyō mondai, p. 92.

17. Fukuda, Nanyō kakyō kō-Nichi undō, p. 293; Nan-yang nien-chien 1939, Sec. V, p. 175. For a more detailed study on the subject, see Chapter III.

18. Fukuda, Nanyō kakyö kō-Nichi undō, p. 293.

19. Japan, Taiwan Sōtokufu Gaijibu, ed., Nampō kakyō yüryokusha meibo (Taihoku, Taiwan: Nampō Shiryōkan, 1942), pp. 15-16. Hereafter, Japan, TSG, Nampö kakyö meibo.

20. Tan Kah Kee, Nan ch'iao hui-i-lu II (Singapore: Nanyang Yin-shua she, 1946), pp. 350-356; Huang Tan-chi, "Ch'en Chia-keng [Tan Kah Kee] hsien-sheng Malang pi-nan-chi," in Ch'en Chia-keng hsien-sheng chi-nien ts'e pien-chi wei-yüan-hui, ed., Ch'en Chia-keng hsien-sheng chi-nien ts'e (Peking: Chung-hua ch'üan-kuo Hua-ch'iao lien-ho hui, 1961), pp. 42-46; Cheng Liang, Ch'en Chia-keng (Hong Kong: Hsin ch'ao ch'u-pan she, 1952), pp. 60-61. 
21. [Minami Manshū Tetsudō] Shanhai Jimusho Chōsashitsu, Kakyō chōsa ihō I (Dairen: Minami Manshū Tetsudō Chōsabu, 1940), p. 96. Hereafter, Mantetsu, SJC, Kakyō chōsa ihö.

22. Japan, Gaimushō Jōhōbu, Nanyō kakyō mondai, p. 93; Nankyō tsūshin, October 12, 1937; Töa jōhō, No. 274 (November 15, 1937), p. 19.

23. Japan, Gaimushō Jōhōbu, Nanyō kakyō mondai, pp. 94, 95, 97; Nankyō tsūshin, October 12, 19, 1937; Japan, TSKG, Nanyō kakyō jijō, p. 82.

In December, this eviction campaign spread to Kuala Lumpur. Japanese officials requested the British authorities to intervene in the case. Some Chinese landowners remained adamant in their demands. Two Chinese were brought to the court for a settlement.

24. Japan, Gaimushō Jōhōbu, Nanyō kakyō mondai, p. 94; Nanyō Kyōkai, Nampō keizai kondankai hökoku sho, p. 93.

25. Japan, Gaimushō Jōhōbu, Nanyō kakyō mondai, p. 96; Japan, Gaimushō Tsūshō-kyoku, Shina jihen to tai-Nichi boikotto mondai, p. 67; Nankyō tsüshin, December 2, 1937; Asahi Shimbun (Tokyo), December 2, 1937. Cf. Victor Purcell, The Memoirs of A Malayan Official (London: Cassell \& Co., 1965), p. 306.

26. Purcell, The Chinese in Southeast Asia, p. 365.

27. Ibid., p. 364; Mantetsu SJC, Kakyō chōsa ihō I, p. 55.

Yang Kuo-ch'ün, a Communist, directed the China Committee for the Eradication of Inferior Goods and the China Association for the Promotion of Chinese Goods.

28. Purcell, The Chinese in Southeast Asia, p. 364.

29. Ibid., Purcell, The Memoirs of A Malayan Official, p. 306.

30. Mantetsu SJC, Kakyō chōsa ihō I, p. 55; Fukuda, Nanyō kakyö kö-Nichi undō, p. 278; Japan, Taiwan Sötokufu Gaijibu, Nampō kakyō dantai chōsa (Taihoku, Taiwan: Taiwan Sōtokufu, 1943), pp. 109-110. Hereafter, Japan, TSG, Nampō kakyō dantai; Kanan Ginkō Shingapōru shiten, "Kakyō sonota jōhō ni kansuru ken," Shinchō No. 17 (May 9, 1938), pp.

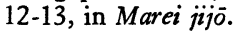

Tan Kah Kee, Kow Say Huan, and Chow Hean Swee were leaders of the Malaya AntiEnemy and National Salvation Corps for the Eradication of Traitors and the Chinese National Liberation Vanguard Corps. All of the three leaders were executive members of the Nanyang Chinese Relief General Association. Kow, Tan's portegé, was a principal figure of the two underground organizations. For Kow Say Huan, see p. 73.

31. Japan Gaimushō Jōhōbu, Nanyō kakyō mondai, p. 96.

32. Nankyō tsüshin, October 12, November 19, and December 12, 1937.

On November 27, Chinese construction workers went on strike and two days later thirty Chinese coolies, working for a Japanese hotel, joined in sympathy with the carpenters' strike. In December, several cases of rowdyism were reported.

33. Nankyō tsüshin, December 23, 1937; Japan, TSKG, Nanyö kakyö jijö, p. 82; Japan, Gaimushō Jōhōbu, Nanyō kakyō mondai, p. 99.

34. Japan, Gaimushō Jōhōbu, Nanyō kakyō mondai, pp. 99-100.

35. Cf. Purcell, The Chinese in Southeast Asia, p. 364-365; Purcell, The Memoirs of A Malayan Official, p. 306.

36. Japan, TSKG, Nanyō kakyō jijō, p. 85.

37. Nankyō tsūshin, January 1, 1938; Japan, Gaimushō Jöhöbu, Nanyō kakyö mondai, pp. $100-101$

38. Japan, Taiwan Sōtokufu Kambō Gaijika, Eiryō Marei to kakyö (Taihoku, Taiwan: Taiwan Sōtokufu, 1938), p. 63; Nankyö tsüshin, January 20, 1938.

39. Ibid.

40. Nankyö tsüshin, January 20, 1938.

41. Japan, TSG, Nampō kakyō dantai, p. 109.

42. Japan, TSKG, Nanyō kakyö jijō, p. 88; Fukuda, Nanyō kakyō kō-Nichi undō, p. 279.

43. Remer, A Study of Chinese Boycotts, p. 15.

44. Mantetsu SJC, Kakyō chōsa ihō I, p. 46.

45. Nanyō XXV, No. 9 (September, 1939), p. 96.

46. Nanyō XXIV, No. 4 (April, 1938), pp. 104-105.

47. Straits Times, March 4, 1938.

48. Minami Manshū Tetsudō Tōa Keizai Chōsakyoku, Eiryō Marei Biruma oyobi Gōshū ni okeru kakyō Nanyō kakyō sōsho V (Tokyo: Minami Manshū Tetsudō Tōa Keizai Chōsakyoku, 1941), p. 585. Hereafter, Mantetsu TKC, NKS V; Japan, Gaimushō Jōhōbu, Nanyō kakyō mondai, pp. 103-104.

49. Mantetsu TKC, NKS V, p. 585; Japan, Gaimushō, Jōhöbu, Nanyō kakyō mondai, pp. 105-106; Nanyō XXIV, No. 8 (August, 1938), pp. 95-96.

50. Japan, Gaimushō Jōhōbu, Nanyō kakyō mondai, p. 106.

51. Ibid., p. 107; Nankyō tsüshin, July 6, 1938. 
52. Nanyō XXIV, No. 10 (October, 1938), pp. 97-98.

53. Ibid., pp. 98-99; Japan, Gaimushō Jōhōbu, Nanyö kakyö mondai, p. 107.

54. Tan Kah Kee, Nan ch'iao hui-i-lu II, p. 83; Nankyō tsüshin, July 29, 1938.

55. Japan, Gaimushō Jōhōbu, Nanyō kakyō mondai, p. 107; Mantetsu TKC, NKS V, p. 568; Nanyō XXIV, No. 10, pp. 100-101.

56. Nanyö XXIV, No. 10 , p. 99.

57. Asahi Shimbun (Tokyo), September 20, 22, 1938. According to this Asahi dispatch from Singapore, the identity of the Anti-Enemy Volunteers' Corps was disclosed for the first time as a result of the arrest of the leaders. Cf. Tsutsui Chihiro, Nampo gunseiron (Tokyo: Nippon Hōsō Shuppan Kyōkai, 1944), p. 148.

Su Tang-jung and Ku Chün-ying, cadres of the Chinese Liberation Vanguard Corps, were also arrested. In connection with these arrests in August, the Singapore police authorities issued a statement that "they [Wang and Chan] were arrested on the charge of inciting an insurrection, contrary to rumors that they were taken into custody on the account of their genuine patriotic action." Nanyō XXIV, No. 11 (November, 1938), p. 122.

58. Straits Times, August 23, 1938, cited in Nanyō XXIV, No. 11, p. 122; Fukuda, Nanyō kakyö kö-Nichi undö, p. 285.

Besides the Youth Le-hsin she, other cultural and recreational societies were very active in disseminating war news and in raising funds. They included, for instance, the Youth Li-chih she, the T'ung-teh shu-pao she, the Ai-hua Musical Drama Society, the Yeh-yü Story and Drama Society, the Ai-hua Athletic Society, the Yang sheng Schoolmate Society, and others. All were duly registered associations. Club.

59. Japan, TSG, Nampō kakyō dantai, p. 106. Tan Kah Kee was the president of the

60. Fukuda, Nanyō kakyö kö-Nichi undō, pp. 293-294.

61. Nanshi Chōsakai, Yüryokusha kakyō meibo, No. 7, 1938, n.p.; Japan, TSG, Nampö kakyö meibo, pp. 15-16; Japan, TSKG, Nanyö kakyö jijö, pp. 68-69.

62. The Association even acquiesced in the purchase of fish from Japanese fishermen during the boycott in order to raise funds from duties imposed on foreign purchases.

63. Sin Chew Shih Nien (Singapore: Sin Chew Jit Poh She, 1940), p. 991, cited Fukuda, Nanyö kakyö kö-Nichi undö, p. 302.

64. Ibid., p. 991, cited Ibid., p. 303.

65. Ch'en Chia-keng Chin shih chih (Chungking, 1941), p. 13, cited in Ibid., p. 304.

66. Japan, TSKG, Nanyō Kakyö Jijö, p. 89.

67. Ibid.

68. Ibid., p. 95.

69. William E. Fisher, "Nanyang Chinese Contribute Large Sums to China's War Chest," China Weekly Review LXXXVIII (May 13, 1939), p. 343.

70. Straits Times, September 15, 1938, cited in Nanyō XXIV, No. 11, p. 122; Asashi Shimbun, September 22, 1938; Nankyö tsüshin, September 15, 1938.

On September 3, a colonial official served a warning to Chinese leaders that the government would not tolerate the activity of legal and illegal organizations for arousing anti-Japanese feelings and collecting refugee relief funds to be sent to China. He specifically mentioned such organizations as a musical drama society and shu-pao she. Nanyö XXIV, No. 12 (December, $1938)$, p. 103.

This Nanyo source did not mention the names of the specific musical drama society and shu-pao she. According to an official study on the overseas Chinese organization, the Ai-hua Musical Drama Society was the most well known organization of this kind. The Ai-hua Musical Drama Society had been very active in the National Salvation Movement. After the war, Chinese established numerous musical and drama groups for the dissemination of war news. They were secret societies. Japan, TSG, Nampö kakyö dantai, pp. 102-104.

71. Ōshima Shigeo, Eiryō Marei ni okeru kakyō no hai-Nichi undō genjō to sono tembō (Dairen Minami Manshū Tetsudō Sōsaishitsu Kōhōka, 1939), p. 23. Marked "Secret." Mimeo.

72. Japan, Gaimushō Jōhōbu, Nanyō kakyō mondai, p. 109; Consul General Kobayashi (Batavia) to Foreign Minister Hirota, August 17, 1937; Nanyö Kyökai Surabaya Shöhin chinretsujo tsüshin, July 20, 1937. Hereafter, Nankyō tsüshin (Surabaya).

73. Mantetsu TKC, NKS IV, pp. $377 \mathrm{ff}$.

74. Fukuda, Shōzō, Kakyō keizai ron ('Tokyo: Ganshōdō Shoten, 1939), p. 97.

75. Fukuda, Nanyō kakyō kō-Nichi undō, pp. 328-336.

76. Ibid., pp. 336-337.

77. Chinese Yearbook, 1940-1941, p. 755, cited Ibid., p. 337.

78. Ibid., p. 339

79. Ibid., p. 384; Japan, Gaimushō Jōhōbu, Nanyō kakyō mondai, p. 110. 
80. Japan, Gaimushō Jōhōbu, Nanyō kakyō mondai, p. 111; Mantetsu TKC, NKS IV, pp. $383,392$.

81. Japan, Gaimushō Jōhōbu, Nanyö kakyō mondai, p. 113.

82. Ibid., pp. 109, 110, 112; Japan, Gaimushō Tsūshōkyoku, Shina jihen boikotto mondai, pp. 69-70.

83. Japan, TSKG, Nanyō kakyō jijō, p. 114; Higashi Indo Nippō (Batavia), October 23, 1937; Japan, Takumukyoku Nanyōka, Shina jihen ka ni okeru Nanyō kakyō, n.p.

The Japanese Ministry of Foreign Affairs heavily subsidized the Higashi Indo Nippō according to an official Dutch source. Netherlands Information Bureau, Ten Years of Japanese Burrowing in the Netherlands East Indies (New York: Netherlands Information Bureau, 1942?), p. 27.

On October 21, the Association's emergency meeting ratified the boycott resolutions. A few weeks before the resolutions were adopted, the Association's lawyer, Mr. Phao, said: "It is difficult to carry out a successful boycott against Japanese goods, because in the past ten years the situation has changed, since the number of Dutch merchants directly importing Japanese merchandise has increased and a network of Japanese and indigenous retailers has expanded. A boycott will weaken the position of Chinese merchants." It was not clear whether Mr. Phao was speaking for himself or for the Association. Kaga Misao, a Japanese wholesaler in Surabaya who lived in the Indies for more than thirty years, believed that Phao was possibly speaking for a segment of the Association. Japan, Gaimushō Jōhōbu, Nanyō kakyō mondai, pp. 112-113; Japan, Gaimushō Tsūshōkyoku, Shina jihen boikotto mondai, pp. 70-71.

84. Nanyō Kyōkai, Nampō keizai kondankai hōkokusho, p. 211.

85. Ibid., p. 71 .

86. Mantetsu, TKC, NKS IV, p. 375.

87. For example, Miyoshi Shunkichirō, former vice Consul in Batavia, characterized Chinese patriotism as a show-off; overseas Chinese support for Chiang Kai-shek was a calculated mien $t z u$, a face-saving device. Chinese might declare boycott as a token demonstration of protest in the initial stages to protect their mien-tzu, but their enthusiasm would dissipate quickly as they were not so much interested in politics as they were in business. See Miyoshi Shunkichirō, Nanyō kakyō ni tsuite (Tokyo: Tōa Kenkyūjo, 1940), p. 12; Takei Jurō, Waga Nanyō böeki wo sogai suru kakyō no shinsō (Tokyo: Tōa Keizai Chōsakyoku, 1932), p. 35; Itō Ken, "Nanyō kakyō no dōkō to Ō-seiken," Kokusai chishiki oyobi hyōron XXI (November, 1941), p. 57.

88. Mantetsu, TKC, NKS IV, pp. 377-394.

89. Ibid., p. 395; Japan, TSKG, Nanyö kakyō jijō, p. 135.

90. Mantetsu, TKC, NKS IV, pp. 396-397; Japan, TSKG, Nanyō kakyō iijō, pp. 125-126, 131-132; Japan, TSG, Nampō kakyö meibo, pp. 40, 45-46.

Lie Kiem Tjoan possessed Japanese citizenship. Kwee Bok Ai had a Japanese wife and a very close business tie with Japan, which he visited frequently.

91. Willmott, The Chinese of Semarang, Chap. V, particularly, pp. 101-102, 105-106.

92. Ibid.

93. Japan, Gaimushō Jōhōbu, Nanyō kakyō mondai, pp. 114-115, 119-124.

94. Mantetsu, TKC, NKS IV, pp. 338-339.

95. Tjong See-gan was the president of the Chinese Chamber of Commerce in Batavia and an influential member of the Association. He was the most prominent Fukienese leader in the Chinese community in Java as well as a member of the KM'T Ts'an-cheng-yüan, the political council of the KMT legislative body. Japan, TSG, Nampō kakyō meibo, pp. 35-36; Taiwan Ginkō, Jikyoku Keizai Iinkai, Batabiya kakyō chōsa (Batavia: Taiwan Ginkō Batabiya Shiten, 1939), pp. 32-33. Marked "Restricted." Mimeo.

96. Japan, Gaimushō Jōhōbu, Nanyō kakyō mondai, p. 117.

97. The Dutch colonial government did not have a specific anti-boycott law. The government prohibited political activities of the native Indonesians and the Chinese.

Cf. As far back as 1923, the colonial office admitted, in response to a Japanese protest against a Chinese boycott, that there was no specific law to bring boycott instigators to justice. Letter from the Netherlands Governor General to Consul General Matsumoto (Batavia), June 11, 1923. Japan, Ministry of Foreign Affairs, MT 681, p. 500. Microfilmed.

98. Japan, Gaimushō Jōhōbu, Nanyō kakyō mondai, p. 117; Mantetsu TKC, NKS IV, p. 380; Fukuda Shōzō, Jaba kakyō no kinkyō (Tokyo: Tōa Keizai Kondankai, 1944), pp. 10-16.

99. Japan, Gaimushō Jōhōbu, Nanyō kakyō mondai, pp. 124-125; Fukuda, Nanyo kakyō kō-Nichi undō, p. 289.

The Chinese Consul General at Batavia subsidized the Thien Sung lip Po, a KMT organ. The other four newspapers followed principles of Sun Yat-sen's teachings in their editorial policy. Tsukimura, Töa kenkyujohō, No. 11, pp. 140-143. 
100. Purcell, The Chinese in Southeast Asia, p. 546; Japan, Gaimushö Jōhōbu, Nanyō kakyō mondai, p. 134; Taiwan Takushoku Kabushiki Kaisha Chōsaka, Nanyō kakyō to sono taisaku (Taihoku, Taiwan: Taiwan Takushoku Kabushiki Kaisha Chōsaka, 1942), p. 132.

101. Japan, Gaimushō Jōhōbu, Nanyō kakyō mondai, pp. 118-124; Nanyō Kyōkai, Nampō keizai kondankai hōkokusho, p. 71.

102. Fukuda, Nanyō kakyō kö-Nichi undō, p. 329.

103. Mantetsu, TKC, NKS IV, Appendix, p. 2; Japan, TSG, Nampō kakyō meibo, p. 31; Japan, TSKG, Nanyō kakyō jijō, p. 120.

It is particularly of interest to note that Ch'iu was not arrested after the Japanese occupation. See Osaka Mainichi, April 15, 1942.

104. Willmott, The Chinese of Semarang, pp. 103-116.

105. Mantetsu, TKC, NKS IV, Appendix, p. 4; Japan, TSG, Nampō kakyō meibo, p. 36; Japan, TSKG, Nanyō kakyō jijō, p. 120.

106. As late as 1940 , Japan was demanding that the Netherlands authorities repress the Chinese who, Japan charged, were permitted to carry on the anti-Japanese boycott. International Military Tribunal for the Far East, Exhibit 1311. Demands of August 14, 1940, against the Netherlands East Indies. Hereafter, IMTFE.

107. Japan, Gaimushō Jōhōbu, Nanyō kakyō mondai, p. 140; Japan, Gaimushō, Kakyō kenkyū shiryō (Tokyo: Gaimushō, 1942-1943), p. 96. Marked "Secret."

108. Ibid.; Japan, Takumukyoku Nanyōka, Shina jihen ka ni okeru Nanyō kakyō, n.p., General Ts'ai left for China on July 20. He was a member of the Overseas Chinese Commission, the Government of People's Republic of China.

109. Chen Chu-pei, Chinese and the War in the Philippines, unpublished manuscript submitted to the Institute of Pacific Relations, 1948?, pp. 9-10.

"To the Kuomintang group belonged Ong Chuan-sien, Sy Yat-sien, Sai Kuo-chüan, Tan Unliong, Go Chun-ming, Lim Shu-an, Justo Cabo Chan and others; to the Chamber of Commerce group belonged Dee C. Chuan, Yu Khe Thai, Alfonso Sycip [Hsueh Fen-shih], Tan San-tua [Samto], Dee Huan-chai [Huanchay], Co Yu-chiu [ch'ao] and others. Go Puan-sien [seng], Yü I-t'ung, Yu Ching-chin, president of the Chinese Education Association, and Gan Bun-chu, principal of the Anglo-Chinese School, were considered intellectual leaders. These men had an indirect connection with the Chamber of Commerce group."

$\mathrm{Yu}$ Khe Thai, Dee C. Chuan's successor as president of the Enemy Resist Committee, Sy Yat-sien, the boss of the KMT, and Alfonso Sycip Hsueh Fen-shih formed the leading trio. 74,76 .

See also, Japan, TSG, Nampö kakyö meibo, p. 13; Japan, TSG, Nampō kakyö dantai, pp.

110. Japan, Gaimushō Jōhōbu, Nanyõ kakyō mondai, p. 140; Japan, Gaimushō Nanyōka, Kakyö kenkyü shiryö, p. 96; Japan, Takumukyoku, Nanyōka, Shina jihen ka ni okeru Nanyō kakyō, n.p.

111. Dote Toshimatsu, "Kon jihen ka Fuirippin kakyō boikotto jōkyō," Shanhai Tōa Dōbunshoin Daigaku Töa chōsa hōkoku (Shöwa 14 nendo), 1940, pp. 1128-1236. Marked "Secret." Hereafter, Dote, "Fuirippin kakyō," TDDTCH.

Present at the meeting and elected to offices of the PREC were business leaders and KMT members. Dee C. Chuan was chairman but later withdrew from his office owing to his poor health. He died of tuberculosis in the United States in October, 1941. Yu Khe Thai succeeded to his office.

112. Japan, Gaimushō Nanyōka, Kakyō kenkȳ̄ shiryō, pp. 97-98; Japan, Gaimushō Oakyoku Dai sanka, Nanyö to kakyō, p. 389. In less than two weeks, the Chinese collected 200,000 yuan.

113. Japan, Gaimushō Nanyōka, Kakyō kenkyū shiryō, p. 98; Japan, Gaimushō Oakyoku Dai sanka, Nanyō to kakyō, pp. 390-391; Mantetsu SJC, Kakyō chōsa ihō I, p. 78; Toda Tatsuo, "Fuirippin kakyō," Shina jihen to kakyō (Taihoku, Taiwan: Taiwan Takushoku Kabushiki Kaisha, 1939), p. 112. Hereafter, Toda, "Fuirippin kakyō," SJK.

The KMT government allocated fifteen million yuan for the Filipino-Chinese to subscribe the bonds. In three months, they subscribed nearly 2.74 million yuan.

114. Toda, "Fuirippin kakyō," SJK, p. 112.

115. Ibid.; Japan, Takumukyoku Nanyöka, Shina jihen ka ni okeru Nanyö kakyö, n.p.

In mid-August, it was rumored in Manila that some radical Chinese were preparing plans for a mass assault upon Japanese residents. Philippine Herald, August 19, 1937.

116. According to a Dömei (Japanese official news agency) dispatch from Manila, as it appeared in the Boruneo Shimbun (Japanese newspaper published in Borneo), November 17, 1943, Tseng surrendered to the Japanese troops in November, 1943, after two years of hiding. $\mathrm{He}$ was quoted to have pledged to cooperate with the Japanese upon his release. Later he served as president of the Chinese association in November, 1944. Cf. Chen, Chinese and the War in the Philippines, p. 30. Chen said Justo Cabo Chan, that is, Tseng T'ing-Chüan, sur- 
rendered himself to the Japanese, through Go Co-lai's good office. Go was president of the Japanese-sponsored Chinese Association until he was assassinated. "He [Tseng] was reported to have given the Japanese authorities a list of Chinese guerrillas' names as the condition for saving his own neck. As a result, about 300 Chinese youths and suspects were thrown into prison, and many were executed." Tseng's own account differed considerably from Chen's. Tseng said he surrendered because his mother was gravely ill and lives of more than 120 of his relatives were in danger. His colleagues suggested he surrender to save his relatives and to scout the enemy. Ch'en Hsiao-yu, ed., Fei-lü-pin yü Hua-ch'iao shih-chi ta kuan (Manila: Fei-lipin yü Hua-ch'iao shih-chi ta kuan chu pien she, 1948), vol. I, sec. 6, pp. 10-12, vol. II, sec. 11, p. 5.

According to my informant, who is a close friend of Tseng, Tseng resigned from the presidency of the Japanese sponsored Chinese Association "due to threats imposed on him by the Chinese guerilla forces in Manila. After the liberation of the Philippines, the Chinese guerilla forces which were connected with the Communist movement in China tried to assassinate Tseng but Tseng's eldest son covered him and died in his place." Correspondent, March 20, 1969.

The Chinese source cited above mentioned that he was tried after the war for his collaboration but was cleared of the charge of collaboration.

117. Toda, "Fuirippin kakyō," SJK, p. 112; Japan, Takumukyoku, Nanyōka, Shina jihen ka ni okeru Nanyö kakyō, n.p.; Japan, Gaimushō Jōhōbu, Nanyō kakyō mondai, p. 142.

Hsü gave a stinging anti-Japanese speech to the student body of the Far Eastern University on August 28. Manira Nichi Nichi (Manila), September 9, 1937, cited in Nanyö XXIII, No. 10 (October, 1937), p. 119.

118. Toda, "Fuirippin kakyō," SJK, p. 113.

119. Nan-yang nien-chien 1939, Sec. V, pp. 181-183; Huang Ching-wan, Hua-ch'iao tui tsu-kuo ti kung-hsien (Shanghai: T'ang ti she, 1940), p. 189.

120. The KMT officials who visited the Islands were P'an Kung-chan, a key official of the KMT Central Headquarters and a right-hand man of Ch'en Li-fu; Ch'en Shu-jen, chairman of the Overseas Chinese Affairs Commission; and Li Hao-chu, former Consul General at Manila. Japan, Gaimushō Jōhōbu, Nanyō kakyō mondai, p. 144; Chen, Chinese and the War in the Philippines, pp. 10-11.

121. Japan, Gaimushō Jōhōbu, Nanyō kakyō mondai, p. 143, 145; Kyōdō tsūshin, October 31, 1937, cited in Minami Manshū Tetsudō Töa Keizai chōsakyoku, Fuirippin ni okeru kakyō, Nanyō kakyō sōsho III (Minami Manshū Tetsudō Tōa Keizai chōsakyoku, 1939), p. 177. Hereafter, Mantetsu TKC, NKS III.

The League issued an organ paper in English, Manila Guardian. The paper publicly endorsed a boycott against Japanese goods. As a result, the Philippine authorities denied the paper the privilege of using the postal service. The League was a Communist front organization. Cf. Brimmel, Communism in Southeast Asia, p. 151.

122. Mantetsu TKC, NKS III, p. 177; Toda, "Fuirippin kakyō," SJK, p. 113. Santos later joined the Philippine Communist Party. It is interesting that Tseng even approached the Sakdalista, which was sympathetic toward Japan.

For Japanese relations with the Sakdalista, see Grant K. Goodman, Four Aspects of Philippine-Japanese Relations, 1930-1940 (New Haven, Conn.: Yale University Southeast Asia Studies, 1967), Monograph Series 9, Chap. 3.

123. Japan, Gaimushō Jōhōbu, Nanyō kakyō mondai, p. 146; Dote, "Fuirippin kakyō," TDDTCH, p. 1212.

124. Japan, Gaimushō Jōhōbu, Nanyō kakyō mondai, p. 147; Toda, "Fuirippin kakyō," SJK, pp. 113-114; Mantetsu TKC, NKS III, p. 178.

Between December 15, and the end of the month, the Chamber of Commerce held three meetings to ponder the problem but it could not reach a consensus.

125. Dote, "Fuirippin kakyō," TDDTCH, pp. 1211, 1213.

126. Ibid., p. 1211.

127. Ibid., p. 1213; Japan, Gaimushō Jōhōbu, Nanyō kakyō mondai, pp. 148, 149, 152. According to acting Consul General Kihara Jitarō, as told confidentially by chief of the Police Affairs Bureau of the Manila Municipality, Communists had been detected in the Chinese antiJapanese activities.

128. Manila Daily Bulletin, February 4, 1938.

129. Köain jōhō, No. 11 (February 1, 1940), p. 84. Marked "Secret."

It was reported that just prior to the vote Tseng and Lim denounced the vacillating colleagues as "unpatriotic" and threatened them with assassination if they did not go along with their faction.

130. Nanyō Kyökai, ed., Fuirippin ni okeru kakyō Nikka haiseki (Tokyo: Nanyō Kyōkai, 1938?), cited in Mantetsu TKC, NKS III, pp. 183-185; Dote, "Fuirippin kakyõ," TDDTCH, 
pp. 1222-1226. Upon the ratification of the boycott regulations, the PREC issued a directive to all its branches in the Islands to act in concert with the boycott movement.

131. Japan, Gaimushō Jōhöbu, Nanyō kakyō mondai, pp. 154, 156. Members of glasswares, knitted goods, and chinawares associations and others protested to the PREC of the futility of the boycott, arguing that it would bring more harm than good to the Chinese economic position.

132. Köain jōhō, No. 11, p. 89; Sen’i seihin Yushitsu Shinkō Kabushiki Kaisha Kikakubu, Fuirippin kakyö gaikan, p. 167.

It is not clear why Hsü was reassigned. In March, 1942, the Japanese military executed Consul General Yang and his staff.

133. Japan, Gaimushō Jōhōbu, Nanyō kakyō mondai, p. 157; Cf. Purcell, The Chinese in Southeast Asia, p. 546.

134. Dote, "Fuirippin kakyō," TDDTCH, p. 1216.

135. Ibid., pp. 1216-1217; Japan, Gaimushō Jōhōbu, Nanyō kakyō mondai, p. 158.

An unconfirmed report of the massacre of 3,000 Chinese by the Japanese troops at the time of the fall of Amoy incensed the Chinese.

Up to this time, some Chinese had outwitted boycott leaders by changing dates of contracts to a date before February 28, 1938, taking advantage of a boycott provision that permitted the completion of the contract that had been concluded prior to that date; by purchasing Japanese goods after sundown; by giving a large contribution in exchange for leniency; by making up a Filipino name for invoice; or by having purchased-Japanese goods transported to a Filipino home in a remote area.

136. Japan, Gaimushō Jōhōbu, Nanyō kakyō mondai, p. 159.

137. Kenkyü shiryō I, No. 8 (August, 1938), pp. 5-6.

138. Nanyō XXIV, No. 10 , p. 102 .

139. The Japanese military blackmailed Dee C. Chuan, Yu Khe Thai, and Tan Samto with a threat that it would confiscate their property in Japanese-occupied Amoy if they did not stop boycott activity. It was reported that they refrained from attending boycott meetings after June, 1938. Japan, Gaimushō Jōhōbu, Nanyō kakyō mondai, p. 160.

140. Mantetsu TKC, NKS III, pp. 189-190; Japan, Gaimushō Jōhōbu, Nanyō kakyō mondai, p. 161 .

The Japanese in Manila were concerned with the KMT's anti-Japanese propaganda campaign. Consequently, Consul General Uchiyama Kiyoshi suggested the Foreign Office in Tokyo arrange a courtesy call of the "Nanking Renovation Government" upon President Quezon when he arrived in Shanghai on his way back to Manila from Tokyo, where he had visited. Uchiyama hoped that such a meeting with the Philippine leader, emphasizing the Nanking government's "good neighbor policy based on friendship between China and Japan as well as the opposition to the anti-Japanese policy of certain overseas Chinese," would be useful in persuading Quezon to "oppose the anti-Japanese boycott in the Philippines." JMFA [Japan, Ministry of Foreign Affairs] L. 1.3.0.2-9, July 8, 1938. Secret, cited in Goodman, Four Aspects of Philippine-Japanese Relations, p. 220.

141. Japan, Gaimushō Jōhōbu, Nanyō kakyō mondai, pp. 121, 145.

142. Ibid., pp. 103-111; Nan-yang nien chien 1939, Sec. V, p. 182.

143. Köain jōhō, No. 11, p. 91; Toda, "Fuirippin kakyö," SJK, pp. 119-120; Nan-yang nien-chien 1939, Sec. V, pp. 181-182. The Women's Associations had raised about 700,000 yuan by the end of 1940 .

144. Köain jöhō, No. 11, p. 91; Toda, "Fuirippin kakyō," SJK, pp. 119-120.

145. Philippine Herald, July 19, 1938, cited in Toda, "Fuirippin kakyō," SJK, p. 120.

The Chinese had been getting some sympathy from the Friends of China and the League for the Defense of Democracy. Japan, Gaimushō Jōhōbu, Nanyō kakyō mondai, pp. 150, 151, 153.

146. For Japan-Philippine relations in the 1930's, see Theodore Friend, Between Two Empires (New Haven, Conn.: Yale University Press, 1966); David J. Steinberg, Philippine Collaboration in World War II (Ann Arbor, Michigan: University of Michigan Press, 1967); Grant K. Goodman, Davao: A Case Study in lapanese-Philippine Relations (Lawrence, Kansas: Center for East Asian Studies, the University of Kansas, 1967), and his Four Aspects of Philippine-Japanese Relations.

147. For instance, President Quezon made a statement on the fourth anniversary of the establishment of Philippine Commonwealth, November 15, 1939, that the government would issue no more licenses for the sari sari store (a general merchandise store) to foreigners, i.e., Chinese. Tōa Kenkyūjo, ed., Tōa nisshi I (Tokyo: Tōa Kenkyūjo, 1941), p. 331. Marked "Secret."

148. Acting Consul General Kihara to Foreign Minister Arita Hachirō, November 29, 1939, in Japan, Ministry of Foreign Affairs, Tokyo, 1868-1945. Reel S459. Microfilmed. Hereafter, JMFA. 
President Quezon told Kihara confidentially that he had warned the Chinese Consul General and business leaders not to jeopardize the law and order of society. Because they did not change their attitude in relation to the anti-Japanese movement, he found it necessary to nationalize sari sari stores.

149. G. William Skinner, Chinese Society in Thailand. An Analytical History (Ithaca, New York: Cornell University Press, 1957), pp. 247-248; David Wilson, Politics in Thailand (Ithaca, New York: Cornell University Press, 1962), pp. 19, 56. For instance, the Thai government abstained from voting on the Manchurian incident question in the League of Nations. It also did not cast a vote in 1937, on the resolution submitted by a committee of the League of Nations which found the Japanese military operations in China unjustified.

150. Mantetsu TKC, NKS I, p. 227.

151. Skinner, Chinese Society in Thailand, p. 242.

152. Ibid., p. 213

153. Japan, TSKG, Nanyō kakyö jijö, p. 44; Mantetsu TKC, NKS I, p. 227; Amada Rokurō, Genchi ni miru Taikoku kakyō (Tokyo: Nanyō Kyōkai, 1939), p. 127; Japan, Gaimushō Tsūshökyoku, Shina jihen to tai-Nichi boikkotto mondai, p. 65.

154. Minister Murai (Bangkok) to Foreign Minister Hirota, August 15, 16, 1937.

155. Japan, Gaimushō Jōhōbu, Nanyō kakyō mondai, p. 126.

156. Ibid.

157. Shamu Kyōkai kaihö, cited in Nanyö XXIII, No. 11 (November, 1937), p. 115.

158. Amada, Genchi ni miru Taikoku kakyō, p. 128; Mantetsu TKC, NKS I, p. 222; Japan, Gaimushō Jōhōbu, Nanyō kakyō mondai, p. 127; Minister Murai to Foreign Minister Hirota, October 7, 1937.

159. Siam Chronicle (Bangkok), October 28, 1937.

160. Japan, Gaimushō Jōhōbu, Nanyō kakyō mondai, p. 127; Japan, TSKG, Nanyō kakyō jijö, p. 45; Mantetsu SJC, Kakyō chōsa ihö I, pp. 47-48.

161. Japan, Gaimushō Jōhōbu, Nanyō kakyō mondai, p. 129; Japan, Gaimushō Tsūshōkyoku, Shina jihen to tai-Nichi boikkotto mondai, pp. 65-66; Japan, TSKG, Nanyö kakyö jijö, pp. $45-$ 46; Mantetsu SJC, Kakyō chosä ihö I, p. 47.

162. Hochi Shimbun (Tokyo), January 25, 1938; Dispatch from Bōeki Assenjo shochō (Bangkok), January 5, 1938.

163. Kenneth P. Landon, The Chinese in Thailand (New York: Institute of Pacific Relations, 1941), p. 31.

164. Japan, Gaimushō jōhōbu, Nanyō kakyō mondai, p. 130.

165. Skinner, Chinese Society in Thailand, p. 244; Mantetsu SJC, Kakyö chösa ihö I, p. 49.

166. Mantetsu TKC, NKS I, p. 224. 1937.

167. Bangkok Times, October 2, 29, November 3, 4, 1937; Siam Chronicle, October 28,

168. Skinner, Chinese Society in Thailand, p. 252.

169. Japan, Gaimushō Jōhōbu, Nanyō kakyō mondai, p. 133; Amada, Genchi ni miru Taikoku kakyō, p. 132

170. Japan, Gaimushō Jōhōbu, Nanyō kakyō mondai, p. 135; Amada, Genchi ni miru Taikoku kakyō, p. 99; Skinner, Chinese Society in Thailand, pp. 244, 261.

A similar charge was leveled at the Chinese in 1914, by Asavabahu, allegedly the pen name of King Rama IV. The fact that Japanese sources played up the similarity between the Jews and the Chinese for a stereotyped business orientation could have been influenced by their interest in Nazi anti-Semitism. There had been a considerable Japanese interest in the study of the Jews since Japan allied with Germany. For instance, Tōa Kenkyūjo and Mantetsa made an extensive study of the Jews.

Prince Wijit Wathakan's speech stirred up a hornet's nest and led to the dissolution of the Assembly and to the fall of the Phahon cabinet. Landon, The Chinese in Thailand, pp. 34-43; Mantetsu TKC, NKS I, pp. 224-225.

171. Nanyō Kyōkai, Nampō keizai kondaikai hōkokusho, pp. 80, 245.

172. Japan, Gaimushõ Jōhōbu, Nanyō kakyō mondai, pp. 131, 134-136; Mantetsu TKC, NKS I, pp. 228; Amada, Genchi ni miru Taikoku kakyō, p. 131; Ide Kiwata, Genchi kakyö gaikan ('Tokyo: Tōyō Kyōkai, 1940), p. 88; Hirano Gunji, "Shamu no kinjō to kakyō," Nanyō XXIV, No. 10, pp. 25-26; Cf. Landon, The Chinese in Thailand, pp. 150-193. Japanese sources reported that 4,200 Chinese were expelled from Thailand.

173. Ch'en was assassinated by an unknown hand on August 16, 1945.

174. Fukuda, Nanyō kakyō kö-Nichi undō, pp. 340-341; Saruwatari Kaku, "Taikoku kakyō," Shina jihen to kakyō (Taihoku, Taiwan: Taiwan Takushoku Kabushiki Kaisha, 1939), pp. 87-88. Hereafter, Saruwatari, “Taikoku kakyō,” SJK.

175. Mantetsu TKC, NKS I, pp. 223-224, 231-232. 
Ting Pe'i-lun, chief of the Munitions Bureau, General Yü Han-mou, commander of the Fourth Route Army in Kwangtung, and Ting Pe'i-tz'u, a representative of General Wu T'iehch'eng, secretly visited Thailand to promote the bond sale campaign.

176. Ibid., pp. 231-232; Japan, TSKG, Nanyö kakyö jijō, pp. 46-47.

177. Japan, TSKG, Nanyō kakyō jijō, p. 46; Japan, Gaimushō Jōhōbu, Nanyō kakyö mondai, pp. 130, 133. For example, more than one hundred terrorists were smuggled into Thailand in February, 1938, of whom sixty were seized by the Thai police.

Liao Ch'eng-chih, chairman of the South China Bureau at Hong Kong, attached to the Eighth Route Army, guided Communist elements of the Thai-Chinese national salvation movement. Mantetsu SJC, Kakyō chōsa ihō I, p. 49.

Liao was, until 1967, chairman of the Overseas Chinese Affairs Committee, People's Republic of China. He was removed from the post during the Cultural Revolution.

178. Mantetsu TKC, NKS I, p. 226.

179. Mantetsu SJC, Kakyö chösa ihö I, pp. 48-49.

180. Huang, Hua-ch'iao tui tsu-kuo ti kung-hsien, p. 163.

Until the General Association was formed, the Chinese in Indochina suffered from lack of leadership and coordination. Under its leadership, the organization expanded control over 35 branches and 100,000 members.

181. Japan, TSKG, Nanyō kakyō jijō, p. 148; Mantetsu SJC, Kakyō chōsa ihō I, p. 62; Ōkubo Yasushi, "Futsuryō Indoshina ni okeru tai-Nichi kanjō ni tsuite," TDDTCH, p. 1171.

182. Japan, Gaimushō Jōhōbu, Nanyō kakyō mondai, pp. 164-165.

183. Mantetsu SJC, Kakyō chōsa ihō I, p. 77.

184. Minami Manshū Tetsudō Tōa keizai chōsakyoku, Futsuryō Indoshina ni okeru kakyō, Nanyō kakyō sōsho II (Tokyo: Minami Manshū Tetsudō Tōa keizai chōsakyoku, 1939), p. 212. Hereafter, Mantetsu TKC, NKS II.

185. Ōya Kasuo, Futsuin seifu no en-Shõ seisaku wo miru (Tokyo: Nippon Gaisei Kyökai, 1939), pp. 31-32. Marked "Top Secret." Mimeo; Ōkubo, "Futsuryō Indoshina ni okeru taiNichi kanjō ni tsuite," TDDTCH, p. 1170; Tōa jōhō, No. 299 (July 5, 1938), p. 40; Satō Jōzō, Tai Futsuin ni okeru sendensen (Tokyo: Nippon Indoshina Kyōkai, 1941), p. 45. Marked "Restricted." Mimeo.

186. Huang, Hua-ch'iao tui tsu-kuo ti kung-hsien, p. 159; Japan, Gaimushō Jōhōbu, Nanyō kakyö mondai, p. 137.

187. Nan-yang nien-chien 1939, Sec. V, pp. 183-184.

188. Taiwan, Nampō kyōkai, Biruma no kakyō (Taihoku, Taiwan: Taiwan Nampō Kyōkai, 1940?), p. 36. Marked "Top Secret."

189. Nanyō XXIV, No. 2 (February, 1938), p. 110.

190. Mantetsu TKC, NKS V, p. 679.

\section{Chapter II}

1. Nan-yang nien-chien 1939, Sec. V, pp. 165ff.; Huang, Hua-ch'iao tui tsu-kuo ti kunghsien, p. 141; Tan, Nan ch'iao hui-i-lu II, pp. 49ff.; Lin A-jen, "Nanyō kakyō no kyūkoku kōsaku," Nanshi Nanyō IX, No. 170 (August, 1939), p. 175.

2. Png, JSAH, pp. 36-37.

3. Delegates from Thailand attended the meeting, but their names were not listed on the official document, possibly for the fear of reprisal from the Thai government.

4. Huang, Hua-ch'iao tui tsu-kuo ti kung-hsien, p. 141.

5. Nan-yang nien-chien 1939, Sec. V, pp. 173-174; Japan, Gaimushō Oakyoku, Nanyō to kakyö, pp. 357-362; Lin, Nanshi Nanyö IX, No. 170, pp. 178-181.

6. Nan-yang nien-chien 19.39, Sec. V, p. 173; Japan, Gaimushō Oakyoku, Nanyō to kakyō, p. 373 .

7. Japan, Gaimushō Oakyoku, Nanyō to kakyō, pp. 371-373.

8. Why Tan Kah Kee accepted the chairmanship, despite his lukewarm support for the organization of the Association, was not known.

9. See pp. 19-20, 41 .

10. Japan, TSG, Nampō kakyö meibo, p. 33.

11 Huang, Hua-ch'iao tui tsu-kuo ti kung-hsien, p. 144.

12. Nankyö tsüshin, November 25, 1938.

13. Ibid.

14. Tan, Nan ch'iao hui-i-lu II, pp. 70-71.

15. Ibid. The allusion refers to Ch'in Kuei of the Sung Dynasty. He has been scorned by patriotic Chinese as a traitor in Chinese history.

16. Ibid., p. 72; Sin Chew lit Poh, November 23, 1938, criticized the KMT for its scorchedearth operation, cited in Nankyö tsüshin, November 23, 1938. 
17. Töa jöhō, No. 217 (January 25, 1939), pp. 43-44. The Three Principles in the Konoye declaration were amity, anti-Communism, and Sino-Japanese economic cooperation.

18. Domei dispatch, January 6, 1939, from Singapore. Tan Kah Kee also cabled to Lin Shen, the President of the Chinese government, demanding that Wang Ching-wei and his collaborators be given capital punishment. See Kanan Ginkō Shingapōru shiten, "Han-Nichi kakyō to Singapōru," Marei jijō (Singapore: Kanan Ginkō, 1938-1939), p. 2. Mimeo.; Dote, "Fuirippin kakyō," TDDTCH, p. 1219.

19. Nanyang Siang Poh, January 1, 1940, cited in Tōa Kenkyūjo, Tōa nisshi I, p. 175.

20. Fukuda, Nanyō kakyō kō-Nichi undō, pp. 247, 250; Tōa Kenkyūjo, Jükei seiken shisaku nenhyō (Tokyo: Tōa Kenkyūjo, 1943), p. 10. Marked "Secret."

21. Fukuda, Nanyō kakyō kō-Nichi undō, p. 250; Tōa Kenkyūjo, Jükei seiken shisaku nenhyō, p. 10.

22. Nanyang Siang Poh, January 1, 1940, cited in Tōa Kenkyüjo, Töa nisshi I, p. 175.

23. O Sei-ei (Wang Ching-wei), "Ni-shi gassaku kōsō Chūgoku han'ei no michi," "Kaigai dōbō ni keikokusu," in Gaikō Mondai Kenkyūkai, ed., O-Shuseki seimei shü, trans. (Tokyo: Nippon Kokusai Kyökai, 1941), pp. 11-12, 53-55.

The first speech was addressed to his important anonymous friend in Hanoi. Wang Chingwei was one of the early revolutionaries who helped found the Penang Library, a revolutionary center for the anti-Manchu group in Malaya. His wife was a daughter of a Hua-ch'iao family in Penang.

24. A group of six Chinese in Singapore sent a letter to Wang Ching-wei in the care of a Japanese agent. They expressed their support for his "policy of peace," urging him to set up his machinery in order to enlighten the overseas Chinese. See Nanshi Chōsakai, "Marei kakyō," in Marei jijō (Tokyo: Nanshi Chōsakai, n.d.), n.p. Mimeo.

25. Matsumoto Sōkichi, "Kakyō mondai ni kansuru kōsatsu," Tōa mondai kenkyū (Tokyo: Nichi Nichi Shimbunsha, 1940), p. 135.

26. The Ministries of Foreign Affairs and Colonial Affairs, the Army and the Navy, the China Development Board, the Planning Board, the South Manchuria Railway Co., the Government General of Taiwan, the Bank of Taiwan, the East Asia Research Institute, the South China Research Institute, the South Seas Research Institute, and the Mitsui, as well as many private firms that dealt business with Southeast Asian countries, had studied the overseas Chinese. Beside carrying out their own research including field trips, these organizations often translated foreign language material on the Nanyang Hua-ch'iao. The Government General of Taiwan had kept a complete list of bibliography on this important overseas minority group. See Taiwan Sōtokufu, Gaijibu, Kakyö bunken mokuroku (Taihoku, Taiwan: Taiwan Sōtokufu, 1944).

27. Memo from Kōain Sōmubuchō to [Kaigun] Gunreibu Jichō, "Shina ni okeru kakyō taisaku ni kansuru ken," June 13, 1939, Shō 14, Seihatsu No. 99; Memo from Kōain Sōmubuchō to [Kaigun] Gunreibu Jichō, "Kakyō kōsaku tōsei ni kansuru ken," June 22, 1939, Shō 14, Seihatsu No. 108, in Japan, Kaigun Gunreibu, Shöwa 12 nen ikō kyü-Shina dōkō, n.d. Marked "Top Secret."

The Navy subsequently established intelligence offices at Amoy and Shanghai, each being headed by a Rear Admiral. The Office was divided into five geographical sections, each in charge of overseas Chinese affairs in French Indochina, Thailand, Malaya, the Dutch Indies, and the Philippines. The Army, under the command of the China Expeditionary Army (CEA), set up a new operation center in Shanghai for overseas Chinese affairs in order to gather intelligence on the situation in Singapore and to induce some influential KMT government officials to come to terms with the Japanese. The CEA, for instance, requested $\mathrm{Li}$ Shui-li, treasurer of the Overseas Chinese Bank at Shanghai, to ask Chou Chao-ch'un, assistant treasurer of the Amoy Hypothec Bank, to make an investigation about Tan Kah Kee's activities and overseas Chinese conditions in Singapore. The Army also planned to use Chou Chih-kang, former mayor of Swatow and a member of the Kwangtung Provincial government, to get in touch with Sung Tzu-wen, Chiang Kai-shek's confidant, through Chou's son, Chou Yen-sei, who was related to Sung Tzu-wen by marriage. The Army's other plan was to undermine the Chiang Kai-shek government by inducing some influential officials to defect from Chungking. For this end, the Army planned to persuade Li Tsung-jen, a leader of the Southwest clique known to be opposing Chiang Kai-shek, through the medium of $\mathrm{Li}$ T'ien-ho, a member of the KMT Examination Yüan and an influential political figure in the Southwest clique. "Shanhai wo chushin tosuru kakyō no dōkō to kakyō kōsaku, Shina hakengun soshireibu," April 19, 1941, Shöwa 17-nen Riku-Shi Mitsu Dai Nikki, Vol. LIV, n.p. Marked "Top Secret."

28. Nanshi Chōsakai [hōkoku], February 22, 1941, No. 1229. Marked "Secret." According to this report from Swatow, the Swatow-Ch'aochow area received eighty-two million yuan from overseas Chinese in the period from March to December, 1940. Of the eighty-two million 
yuan, sixty per cent went to the area controlled by the KMT government. The Japanese permitted remittances to the KMT-controlled area in order to win the hearts of the Chinese.

29. For an optimistic view, see Shigeru Ötsuki, "Chinese in South Seas Turning to Cooperate with Japan," Nippon oyobi Nipponjin (February, 1940), trans. in Contemporary Opinion on Current Topics, Japan, Information Bureau (March 7, 1940); Ide Kiwata, "O-seiken no seiritsu to kakyō no dōkō," Taiheiyō III, No. 5 (May, 1940), pp. 45-46; Imura Shigeru, "O-seiken to kakyō no dōkō," Gaikō jihō XCIII, No. 4 (February 15, 1940), pp. 132-133. For a more realistic view, see Matsumoto, "Kakyō mondai," Töa mondai kenky $\bar{u}$, pp. 135ff.; Fukuma Takeo, Shin kokumin seifu no seijiteki chii (Tokyo: Tōa Kenkyūjo, 1941), p. 48. Mimeo.; Ide Kiwata, "Nanyō kakyō taisaku ron," Taiheiyō IV, No. 5 (May, 1941), pp. 13-22.

Matsumoto said: "We must recognize the fact that the number of Wang Ching-wei supporters is nowhere comparable to that of Chiang Kai-shek supporters." Fukuma observed: ". . . [Overseas Chinese] support for Wang Ching-wei has been insignificant." Completely turning around in his assessment, Ide said that nothing short of the "fundamental solution" of the whole China affair, that is, the subjugation of the Chungking government, would enable the Japanese to carry out the policy of [inducing overseas Chinese to be submissive to Japan].

Japanese sources tended to paint an exaggerated picture of the impact produced by the establishment of the Wang Ching-wei regime upon the Nanyang Chinese. For instance, a writer for Nampō Kyōkai reported after his field trip to Manila that Dee C. Chuan had expressed privately his approval of Wang's policy for peace. Ishida Hatsutoshi, "Manira kakyō ni kansuru chōsa," Nampō III, No. 3 (March, 1941), p. 54. Cf. Asahi Shimbun, April 11, 1940. Also Higashi Indo Nippō, July 18, 1940, and Osaka Mainichi, June 8, 1940, reported an increase in remittances to Japanese-occupied Canton as being indicative of "growing trust in the new government's policy for peace."

30. Japan Yearbook 1943-1944 (Tokyo: Foreign Affairs Association of Japan, 1944), pp. 1055-1058.

By this time, the military's policy for the Chinese had been somewhat modified from the initial one of repression to reconciliation in order to utilize their business talents and their wealth. See General Isoya Gorō's speech to governors and mayors at the Conference of Governors and Mayors held on July 11, 1943. General Isoya, director of the Malay Military Administration, said that he was conveying Premier Töjō Hideki's directive. Shōnan Gensei Kambu, Marei kaku shü (shi) chōkan kaigi kankei shorui toji, July, 1943, n.p. Marked "Secret."

31. Köain jōhō No. 27 (October 1, 1940), p. 74.

32. Nankyō tsüshin, March 25, 1940.

33. Hsin Chung Kuo Pao (Manila), April 10, 1940, cited in Fukuda, Nanyö kakyō kö-Nichi undō, pp. 248-249; Nanyō XXVI, No. 4 (April, 1940), p. 23. Cf. New York Times, April 1, 1940.

34. For instance, the Sin Chew lit Poh warned the Chinese against bribery attempts made upon Chinese merchants and against propaganda activity conducted by Taiwanese of Japanese nationality disguished as Fukienese. Consul General Kao reminded his compatriots of the importance of exterminating traitors. When a periodical, Hua-ch'iao Chi-k'an, a quarterly published by the Wang Ching-wei regime, was discovered to have been smuggled into Malaya, Kao notified the NCRGA, Chinese chambers of commerce, and Fukienese associations to be alert against subversive activities. A similar warning was constantly issued. See Kanan Ginkō Shingapōru shiten, "Han-Nichi kakyō," Marei jijō, p. 8; Fukuda, Nanyō kakyō kō-Nichi undō, p. 249; Nanyō XXVI, Nos. 4, 5 (April, May, 1940), pp. 100, 150; Higashi Indo Nippō, May $9,1940$.

35. In May, the Overseas Chinese Affairs Commission at Chungking notified overseas consulates to discourage Chinese to return home via Amoy and Conros Island because they would be searched or even robbed by enemy agents. It was a countermeasure to a new policy implemented by the Nanking government and Japan's Köain, China Development Board, to win the support of the overseas Chinese. They established reception centers to welcome Chinese from abroad and re-opened agencies to attract remittances from them. Bureaucrats from the Government General of Formosa officered the reception centers and the Bank of Taiwan, the Yokohama Species Bank, and the Hypothec Bank of Japan financed remittance agencies. The receipt of remittances, after the resumption of the service, was said to be on the rise. A study made by the Taiwan Government General in 1943, estimated 116 million yuan to Swatow (March, 1940April, 1941), 27 million yuan to Canton (1940), 17.7 million yuan to Haikow (1940), and 40 million to Amoy (1940). Taking into consideration that the yuan depreciated thirty or more per cent during the period, the Tokyo-Nanking policy to entice the Chinese abroad to remit to these Japanese-occupied ports seens to have been unsuccessful. For a detailed study on remittances, see Chapter III, and for the Navy's criticism on the way the reception centers operated, see pp. 131-132. 
36. Straits Budget (Singapore), July 25, 1940.

37. See pp. 20-21.

38. McLane, Soviet Strategies, p. 241. 157.

39. Virginia Thompson, Postmortem on Malaya (New York: The Macmillan Co., 1943), p.

40. Mantetsu TKC, NKS V, p. 588; Ide Kiwata, Nanyō to kakyō, rev. (Tokyo: Sanseidō, 1943), p. 265.

The MCP decided to strike against the British as they were opposing Germany. During late 1939 and early 1940, the Communist organ, Emancipation News, and the AEBUS organ, Vanguard News, "carried on intense anti-British propaganda. . . ." McLane, Soviet Strategies, p. 242; Brimmel, Communism in Southeast Asia, p. 147.

41. Nanyo XXVI, No. 3 (March, 1940), pp. 99-100. The arrested Chinese were Chuang Ming-li, Huang Liang, and Lin Lung-hua. Chuang works for the Peking government today. 42. Nanyō XXVI, No. 3, p. 109; Ide, Nanyō to kakyō, rev., p. 266; Mantetsu TKC, NKS V, p. 588 .

43. "Basic Paper on the Malayan Communist Party," Vol. I, Part 2, p. 19, cited in McLane, Soviet Strategies, pp. 242-243; Brimmel, Communism in Southeast Asia, p. 148.

44. McLane, Soviet Strategies, p. 243. German attack on Russia in June, 1941, made things easier for the Communists to shift their position.

45. Purcell, The Chinese in Southeast Asia, p. 365.

46. Brimmel, Communism in Southeast Asia, p. 148.

47. Mantetsu, SJC, Kakyö chōsa ihō I, p. 48; Fukuda, Nanyō kakyō kō-Nichi undō, p. 277.

48. Thompson, Postmortem, p. 157; McLane, Soviet Strategies, p. 244; Brimmel, Communism in Southeast Asia, p. 148.

49. Png, JSAH, pp. 36-37.

50. Ibid., p. 38.

51. The San-Min-Chu-I Youth Corps stirred up anti-Japanese feelings in "such alarming proportion" that "Malayan governments were embarrassed ...., because British wished to show clearly its neutral attitude with regards to Japan's war with China." Png, JSAH, p. 38.

52. Fukuda, Nanyō kakyō kō-Nichi undō, p. 252.

53. Ibid., p. 251; Tan, Nan ch'iao hui-i-lu II, pp. 251-254; Chung Yüan Pao, December 25, 1940, cited in Töa nisshi II (Tokyo: Tōa Kenkyūjo, 1943), p. 587. Marked "Top Secret."

One student of the overseas Chinese ventured to say that Tan Kah Kee's support of the Peking government in post-war years might be "related to this long-standing opposition to Ch'en." See Uchida Naosaku, The Overseas Chinese. A Bibliographical Essay Based on the Resources of the Hoover Institute (Stanford, California: Hoover Institute on War, Revolution, and Peace, Stanford University, 1959), p. 56.

For information on Ch'en Yi, see George H. Kerr, Formosa Betrayed (Boston: Houghton Mifflin Co., 1965); Harold Hinton, "China," in George McT. Kahin, ed., Major Governments of Asia, 2nd ed. (Ithaca, New York: Cornell University Press, 1963), p. 134.

Ch'en Yi became the Governor of Formosa in 1945, but he and his carpetbaggers misgoverned the island so badly that on February 27-28, 1947, many of the Formosans rose in revolt only to be massacred. Though Ch'en was relieved from the post, he was immediately appointed to the Governorship of Cheking. In February, 1949, Ch'en was arrested on the charge of having talked of a state socialism under the Communist regime. He was executed in June, 1950, in the midst of an anticipated Communist Chinese invasion of Formosa, for his crime in 1946-47. Presumably, Ch'en was sacrificed in order to win the loyalty of the Formosans if a Communist invasion should take place. Chiang Kai-shek was reportedly reluctant to execute his old friend.

54. Chung Yüan Pao, October 9, 1940, cited in Töa nisshi II, p. 585; Pien-i ch'u-pan she, ed., Chen ching chung-wai ti 'Huan-nan ts'an-an' Mien mien kuan, trans. (Tokyo: Töa Kenkyüjo, 1941), p. 138. Marked “Top Secret." Hereafter, Huan-nan ts'an-an; Tan, Nan ch'iao hui-i-lu I, pp. 162-163; Ts'ai T'ing-kai, "Chi-nien Ai-kuo-lao-jen Ch'en Chia-keng hsien-sheng," in Ch'en Chia-keng hsien-sheng chi-nien-ts'e pien-chi wei-yüan-hui, ed., Ch'en Chia-keng hsien-sheng chi-nien-ts'e (Peking: Chung-hua Ch'uan-kuo kuei-kuo Hua-ch'iao lienho-hui, 1961), p. 15; Chuang Ming-li, "Tao-nien Ch'en Chia-keng hsien-sheng," in Ibid., p. 28.

Tan was reported by Ts'ai to have said that "the Chinese Communist Party united under Mao Tse-tung is China's hope for salvation."

55. Pien-i ch'u-pan she, Huan-nan ts'an-an, p. 137. For Kow Say Huan, see pp. 81-82, Chap. II. 48-49.

56. Cheng Liang, Ch'en Chia-keng (Hong Kong: Hsin ch'ao ch'u-pan she, 1952), pp. 46, 
Tan was said to have been cut off from his contact with the Chinese Communist Party Liaison Office in Chungking. General Ho Ying-ch'in directed military commanders and party heads of all provinces to keep close watch on Tan.

57. Pien-i ch'u-pan she, Huan-nan ts'an-an, p. 138; Chung Yüan Pao, October 9, 1940, cited in Töa nisshi II, p. 585; Tan, Nan ch'iao hui-i-lu II, pp. 186-188.

58. Chung Yüan Pao, October 8, 1940, cited in Töa nisshi II, p. 585

59. According to a Japanese intelligence source, Tan Kah Kee was known to have been sympathetic with the Chinese Communist Party as early as 1938. Japan, Gaimushō Jōhōbu, Nanyō kakyō mondai, p. 132. According to a postwar Communist source, Tan was sympathetic toward the Communists as early as 1932, when the Nineteenth Route Army entered Fukien. He supported, it said, the liberation program of the Nineteenth Route Army, and in the following year, Tan urged the Nineteenth Route Army and the Red Agrarian Army to establish a people's government in Fukien. Ts'ai, "Chi-nien Ai-kuo lao-jen Ch'en Chia-keng hsiensheng," in Ch'en Chia-keng hsien-sheng chi-nien-ts'e, p. 15.

These early so-called sympathetic attitudes of Tan Kah Kee toward the Communists should not be taken too seriously in view of the fact that Tan was a man of action with a particular concern for the welfare of his native province, Fukien. He probably supported the Communist program out of his intense concern for the well-being of his native province, as he had supported the KMT government earlier.

60. Chung Yüan Pao, December 25, 1940, cited in Töa nisshi II, pp. 587-588. Hong Kong Ta Kung Pao, November 7, 1941, cited in Minami Manshū Tetsudō Chōsabu, Senji Shina keizai to kakyō sōkin (Dairen: Minami Manshū Tetsudō Chōsabu, 1942), pp. 94-95. Hereafter, Mantetsu Chōsabu, Shina senji keizai; Kerr, Formosa Betrayed, pp. 53-56; Tan, Nan ch'iao hui-i-lu II, pp. 249, 251-253, 254, 264, 270.

61. Nanyang Siang Poh, January 20, 1941, cited in Nanyö XXVII, No. 6, pp. 29-33; Tan, Nan ch'iao hui-i-lu II, pp. 301-302.

62. For further discussion, see pp. 113-114, Chap. III.

63. Cheng, Ch'en Chia-keng, pp. 44-45.

64. Ibid., pp. 48-49; Chuang, "Tao-nien Ch'en Chia-keng hsien-sheng," in Ch'en Chiakeng hsien-sheng chi-nien-ts'e, p. 28.

65. Png, JSAH, p. 36; Cheng, Ch'en Chia-keng, pp. 48-49; Tan, Nan ch'iao hui-i-lu II, p. 301.

66. Pien-i ch'u-pan she, Huan-nan ts'an-an, p. 61.

67. Ibid. Whether this allegation is true or not cannot be proved until the archives of the Nationalist government are opened. According to my interviews with former generals and staff officers of the Imperial Japanese Army, General Ho did maintain close contact with Japanese agents for peace to save Japan from a complete defeat so as to prevent the emergence of Russia and the United States as preponderant powers in East Asia-the situation that the complete and unconditional surrender of Japan would create. It was a situation KMT China did not wish to see in postwar power relations in East Asia.

68. This charge was often made by critics including American military and civilian officers.

69. For a Communist biased viewpoint of the New Fourth Army incident and reaction of the left circles in Nanyang Chinese communities, see Huan-nan ts'an-an.

70. Tan, Nan ch'iao hui-i-lu II, p. 306; Asahi Shimbun, March 18, 1941; Tokyo, Nichi Nichi Shimbun, March 18, 1941.

71. Tan, Nan ch'iao hui-i-lu II, p. 310. Chu Chia-hua, Minister of Education, tried in vain to persuade Tan to stay in office. Tan, in his letter to Chu, charged General Wu for having accused him of being surrounded by Communists and being disloyal to Chiang Kai-shek.

72. Hong Kong Ta Kung Pao, April 17, 1941, cited in Fukuda, Nanyō kakyō kō-Nichi undō, p. 355 .

73. Ibid., pp. 252, 355.

74. Ibid., p. 355; Tan, Nan ch'iao hui-i-lu II, pp. 308, 315.

75. Fukuda, Nanyō kakyō kō-Nichi undō, p. 355. The expression used to describe Tan is “yang-t'ou kou-ju." It literally means an animal with sheep's head and dog's flesh.

76. Ibid., p. 252; Tan, Nan ch'iao hui-i-lu II, pp. 315-316. Tan labeled Kao as pro-Wang Ching-wei and pro-German and levelled charges at him and his wife for having solicited contributions and bond subscriptions without a prior consultation with his organization.

77. Tan, Nan ch'iao hui-i-lu II, p. 303.

78. Sin Chew Jit Poh, March 30, 1941, cited in Kenkyū shiryō IV, No. 5 (May, 1941), p. 91 .

79. Fukuda, Nanyō kakyō kō-Nichi undō, p. 252.

80. Ibid., p. 355 . 
The old KMT stalwart Ong Chuan-sien of the Philippines was present at the Fukienese Chinese meeting. He protested the absence of KMT government officials in the meeting and invited $\mathrm{Kao}$ to attend. Kao refused to attend it, insisting that he had no instruction from his government. Nanyō Nichi Nichi, April 1, 1941, cited in Kenkyū shiryō IV, No. 5, p. 91.

81. Fukuda, Nanyō kakyō kö-Nichi undō, pp. 356-357.

82. Japanese observers tended to interpret the rift as irreversible, creating an unbridgeable chasm between Tan and the KMT government. The break was not complete at least until post-war years. See Hirano Yoshitarō and Kiyono Kenji Taiheiyō minzoku-Seijigaku (Tokyo: Nippon Hyōron Sha, 1942), p. 184. Suzuki Kan'ichi, "Yuragu Tai, Futsuin no kakyō," Taiheiyō IV, No. 8 (August, 1941); Osaka Mainichi, April 7, 1941; Davao Nichi Nichi (Philippines), May 21, 1941, cited in Nanyō XXVII, No. 7, p. 73.

83. Tan, Nan ch'iao hui-i-lu II, p. 321.

84. Brimmel, Communism in Southeast Asia, pp. 148-149.

85. Cf. Osaka Mainichi, June 21, 1941.

86. According to a recent study, Tan reached the decision to support the Chinese Communist Party sometime between April 30, 1947, and January 1, 1948. On the latter date he announced his decision in the Nan Ch'iao Jit Poh. Ichikawa Kenjirō, "Chin ka-ki [Tan Kah Kee] to kakyō no seiji kenkin," Töyō Gakuhō LI, No. 2 (September, 1968), pp. 17-18.

87. See footnote 50 , Chap. II.

88. Straits Times, July 6, 1940, cited in Töa nisshi II, p. 566-567.

89. Png, JSAH, p. 38; Purcell, The Chinese in Southeast Asia, p. 365.

90. Minami Manshū Tetsudō Shanhai Jimusho Chōsashitsu, Daitōa sensō ga okuchi ni ataetaru eikyō III, Kakyō (Shanghai: Minami Manshū Tetsudō Shanhai Jimusho, 1942), p. 11. Marked "Secret." Mimeo. Hereafter, Mantetsu Shanhai Jimusho, Daitōa sensō-kakyō; David George Kin [Plotkin], Rage in Singapore (New York: Wisdom House, 1942), p. 286.

91. Kin, Rage in Singapore, p. 286.

92. Fukuda, Nanyō kakyō kō-Nichi undō, p. 253.

93. Ian Morrison, Malayan Postscript (London: Faber and Faber Ltd., 1942), p. 165.

94. Ibid., p. 164.

95. Mantetsu Shanhai Jimusho, Daitōa sensō-kakyō, p. 11. G. Z. Hanrahan, The Communist Struggle in Malaya (New York: Institute of Pacific Relations, 1954), pp. 31-32. Mimeo.

96. Morrison, Malayan Postscript, p. 170.

97. Ibid., p. 165.

98. Ibid., p. 171 .

99. For the Malayan People's Anti-Japanese Army, see Spencer F. Chapman, The Jungle is Neutral (London: Chatto \& Windus, 1949).

100. In an editorial of a Chinese Communist newspaper, Chieh-fang Jih Pao (January 16, 1942), cited in Mantetsu Shanhai Jimusho, Daitöa senso-kakyō, p. 12, advocated that the Chung Kuo Council should not remain as an organization for the defense of the interest of the Hua-ch'iao but should arm all Nanyang Chinese for the defense of the Pacific area and for the expulsion of colonial rulers, i.e., the British, the Dutch, the French, and the Americans as well as the Japanese. The editorial also said a ten-to-ten ratio of the KMT-Communist representation in the Council was not satisfactory, suggesting an increase of Communist representation.

Communists were sent to subvert the Council and to achieve their own ultimate objectives. Cf. McLane, Soviet Strategies, p. 243.

For the organization of the Chung Kuo Council, see Ta-chan yü Nan ch'iao pien-tsuan wei-yüan-hui, ed., Ta-chan yu Nan ch'iao Ma-lai-ya chih pu (Singapore: Hsin Nan-yang ch'u-pan she, 1947), pp. 53-54.

In a list of Chung Kuo Council officers, Loi Tek's name did not appear but the Communist Lin Chiang-shih appeared as head of the Armed Masses Department. Lin was a member of the Central Executive Committee. Ichiji.

101. IMTFE, Exhibit No. 3068 Col. Sugita's affidavit; correspondence with General Sugita

102. Morrison, Malayan Postscript, p. 172.

103. When the British authorities requested to defend a beachhead, Tan reportedly was opposed to sacrificing lives of a few thousand untrained volunteers on the grounds that there were several hundred thousands of British soldiers in Singapore. Such a futile resistance, he said, would bring upon the Chinese community a blood bath of massacre after the Japanese occupied the city. Cheng, Ch'en Chia-keng, pp. 59-60.

104. It was disclosed at the time of the trials of General Kawamura Saburō, commander of the Japanese Garrison Army in Singapore, and of kempeitai officers at Singapore in 1947 and in the hearings of the International Military Tribunal, Far East, in Tokyo held in the same year that as many as 5,000 anti-Japanese were executed. No one knows how many died and who ordered the mass execution. I interviewed more than a score of former Japanese military 
and civilian officers who participated in the Japanese Military Administration of Malaya. They maintained the number 5,000 an exaggerated figure; one of them even denied the execution had ever taken place.

Loi Tek and Ching Kee Sun, secretary of the NCRGA, were arrested by the Kempeitai. Ching Kee Sun survived the Kempeitai sook ching (purification by purge).

105. Morrison, Malayan Postscript, pp. 174-175.

106. McLane, Soviet Strategies, p. 232.

107. Harry J. Benda, The Crescent and the Rising Sun. Indonesian Islam under the Japanese Occupation 1942-1945 (The Hague and Bandung: W. van Hoeve, Ltd., 1958), pp. 103-105; Machida Keiji, Tatakau Bunka butai (Tokyo: Hara Shōbō, 1967), pp. 150-151.

108. Nanshi Nanyō IX, No. 165 (March, 1939), p. 176. This suppression policy had been consistent with the Dutch since the early 1930's. The colonial government revoked teachers' licenses when a Dutch inspector found the word "imperialism" in a student's notebook, or expelled Chinese teachers for having taught "patriotism" and a Kuomintang song. Lin and Chu, Nan-yang hua-ch'iao chiao-yu, pp. 275-280.

109. Itagaki Yoichi, Ajia tono taiwa (Tokyo: Shin Kigensha, 1968), pp. 125-152. Professor Itagaki made an academic research trip to the Indies in November, 1940, for three months. While he was in the Dutch colony, his movements were carefully watched and restricted. Many local Japanese residents worked for the Japanese military gathering intelligence information.

110. Yabe Hideo, "Ranryō Higashi Indo kakyō," in Taiwan Takushoku Kabushiki Kaisha Chōsabu, ed., Shina jihen to kakyō (Taihoku, Taiwan: Taiwan Takushoku Kabushiki Kaisha, 1939), p. 107.

111. Netherlands, The Ten Years of Japanese Burrowing, pp. 33-34.

112. Yoshizumi was expelled from Java before the Japanese invasion of the island and was arrested in an attempt to smuggle to Java in December, 1941, and taken to Australia. After being repatriated in 1943, he worked for the Japanese military in Java. He died in Java in 1947.

113. Netherlands, The Ten Years of Japanese Burrowing, pp. $93 \mathrm{ff}$.

114. The Foreign Office in Tokyo in July, 1941, sent special officials to the South Seas for the campaign among the overseas Chinese. The purpose of the mission was to belittle the prestige of the Chungking government and to establish facilities for remittances and investment in the Japanese-occupied area in China. As late as September, 1941, Consul General Ishizawa at Batavia requested the Foreign Office to send to the Indies an influential Chinese ".... who can command large numbers of followers among the Chinese here . . . to spread the doctrine that Chinese and Japanese are one, as well as to set up organizations to influence Chinese opinion." The Netherlands, The Ten Years of Japanese Burrowing, p. 34; IMTFE, Document 15B Telegram of Ishizawa (Consul General at Batavia) to Tokyo, September 2, 1941.

115. IMTFE, Exhibit 1317, Measures for the Economic Development of the Netherlands East Indies, October 25, 1940. Indies.

116. IMTFE, Exhibit 1311, Demands of August 14, 1941, against the Netherlands East

117. Fukuda, Nanyō kakyō kō-Nichi undō, p. 289.

118. Ibid., pp. 335-336.

119. Ibid., pp. 338-339; Chung Yüan Pao, October 20, 1940, cited in Töa nisshi II, p. 617; Haga Takeshi, Tōa Kyöeiken to Nanyō kakyō (Tokyo: Tōkō shoin, 1942), pp. 341-342; Higashi Indo Nippō, November 7, 1940.

120. Fukuda, Nanyō kakyō kō-Nichi undō, p. 337.

121. For the following information, I am indebted to Tsutsui Chihiro, Sumatora (Tokyo: Dai Nippon Shuppansha, 1943), pp. 195ff. Tsutsui was a war correspondent who covered the Malaya-Sumatra military campaign. Information in this book indicates that he was intimate with high officials of the Military Administration. Comparing his information with officially classified material, it appears he got the information from the kempeitai.

122. Dote, "Fuirippin kakyō," TDDTCH, pp. 1226-1227.

123. JMFA J. 1.1.0.X1-U1, March 17, 1939, cited in Goodman, Four Aspects of PhilippineJapanese Relations, p. 33.

124. Fukuda, Nanyō kakyō kō-Nichi undō, p. 323.

125. A special dispatch from Manila, February 16, 1939, cited in Mantetsu TKC, NKS III, pp. 192-193.

126. Osaka Mainichi, May 14, 1939.

The concept of a grave shared by the Chinese from Fukien was reportedly stronger. It was unbearable for them, it is said, to see their ancestors' graves desecrated, though they could bear the brand of traitor. Mantetsu NKC, NKS III, pp. 192-193.

127. Chen, Chinese and the War in the Philippines, p. 42.

128. Ibid., p. 44; Japan, TSG, Nampō kakyō dantai, pp. 80-81. 
129. Chung Hua Jit Po, February 1, 1940; Ta Kung Pao, January 23, 1940; Shanghai China Morning Post, January 25, 1940, all cited in Töa nisshi I, p. 185.

130. Chen, Chinese and the War in the Philippines, p. 44. In December, 1941, Chungking recalled Ong, but he was stranded in Hong Kong when the Pacific War broke out. The Japanese troops arrested him but gave some degree of freedom of movement because of his advanced age. Taking advantage of this freedom, he escaped to China.

131. Manila Daily Bulletin, April 9, 12, May 10, 1940; Fuirippin jōhō, No. 36, p. 19; No. 37, p. 45; No. 38, p. 66; Nanyō XXIV, No. 6 (June, 1940), p. 123; Domei Jumpo, April 14, 1940, cited in Töa nisshi I, pp. 185-186; Sen'i seihin Yushitau Shinkō Kabushiki Kaisha Kikakuka, Fuirippin kakyō gaikan, Chōsa No. 2 ('Tokyo: Sen'i seihin Yushitsu Shinkō Kabushiki Kaisha, 1942), p. 174. Mimeo.

The Manila authorities began an investigation and summoned Yu Khe Thai, acting chairman of the PREC, for questioning. During the interrogation, Yu Khe Thai denied the existence of the anti-Japanese organizations whose names had been presented by Consul General Yoshida, insisting that their activities were of self-defense against the Japanese aggression. The investigation ended without producing the evidence of the complicity as charged by the Japanese Consul General.

The outbreak of violence might also be attributed to the arrival of "several thousand refugees" from China who were driven out from China's southern coast, which the Japanese had occupied, as reported by American High Commissioner Francis B. Sayre to President Franklin D. Roosevelt in July, 1940. Sayre was afraid of the influx of the refugees who might intensify "ffifth column activities in the Philippines. . . ." Francis B. Sayre, Glad Adventure (New York: The Macmillan Co., 1957), p. 214.

132. Chen, Chinese and the War in the Philippines, p. 45; Chung Yüan Pao, October 2, 1940, cited in Töa nisshi, II, p. 580 .

Chen said Wu T'ieh-ch'eng visited Manila in 1941. This is apparently a mistake. Wu arrived in Manila on October 1, and stayed until October 18, when he left for Batavia.

133. Chen, Chinese and the $W$ ar in the Philippines, p. 45.

134. Sy Yat-sien and Cua Chün-ti, shortly before the Japanese troops entered Manila, evacuated the city and organized a guerrilla unit. Sy commanded a Chinese section of the Marking's Fil-American guerrilla forces, and Cua served as Sy's chief of staff. Lin Tso-mei trained the youths, organizing them into a Philippine-Chinese Wartime Service Corps. Ibid., p. 46.

C. C. Fang was manager of the New China Herald and Hsieh Teh-ch'ao was the publisher of the San Yat-sen's Times.

135. The Japanese kempeitai arrested Sai Kuo-ch'üan and Tan Unliong. They remained in custody until 1943, when the Japanese released them. Sai and others were then asked to join the Japanese-sponsored Chinese Association. Ibid., pp. 18, 46-47.

136. Japan, Gaimushō Jōhōbu, Nanyō kakyō mondai, p. 148.

137. "Hitō kakyō to jiban no zento," Daiamondo XXX, No. 16 (June 1, 1942), p. 26.

138. Nanshi Chōsakai [hōkoku] from Manila Office, March 5, 1941, No. 1233. Marked "Secret." Japan, TSG, Nampö kakyö dantai, p. 74.

139. Chen, Chinese and War in the Philippines, p. 34.

140. McLane, Soviet Strategies, p. 228.

141. Brimmel, Communism in Southeast Asia, p. 151; Japan, Gaimushō Jōhōbu, Nanyō kakyō mondai, pp. 149-152.

The Friends of China and the League for the Defense of Democracy jointly sponsored a meeting on January 30, 1938, for the purpose of stirring up anti-Japanese feelings. The Japanese consulate-general prepared evidence for the Mayor of Manila showing that the meeting was organized with the objective of agitating bad feelings against Japan. The meeting was held despite the fact that the Mayor revoked a permit for the assembly. About half of the people gathered were Chinese.

142. McLane, Soviet Strategies, pp. 228-229. Quoting Jose Lava, a Filipino Communist, McLane writes that: "a 'Friends of China' organization was created after the Congress." A Japanese intelligence source identified its existence as early as January, 1938. Japan, Gaimushō Jōhōbu, Nanyō kakyō mondai, pp. 148, 150.

143. McLane, Soviet Strategies, p. 229.

144. Acting Consul General (Manila) to Foreign Minister Arita Hachirō, May 22, 1939. Reel S 459, JMFA.

145. Nanshi Chösakai [Hōkoku] from Manila Office, March 12, 1941, No. 1235.

146. Ibid.

147. Ibid.

148. Ibid. 
149. Domei dispatch from Manila and [Manila Daily] Bulletin, n.d., in Sen'i Yushitsu Shinkō Kabushiki Kaisha Kikakuka, Fuirippin kakyō gaikan, pp. 174-175.

150. McLane, Soviet Strategies, p. 301; Brimmel, Communism in Southeast Asia, p. 213; Chen, Chinese and the War in the Philippines, p. 36.

According to Chen, rumors were circulated shortly before the invasion that "a group of left-wingers arrived from China. Some were formerly connected with the editorial department of the New China Daily News, the official organ of the Communist Party in Chungking; others were military strategists and experts."

As war became imminent in December, 1941, the Chinese left-wingers organized themselves into an anti-Japanese guerrilla force under the leadership of Ong Seh-hsiun (Ong Keit). This guerrilla unit, later known as Squadron 48, was said to be connected with Mao Tse-tung's Fourth and Eight Route Armies through Ong Seh-hsiun.

151. Yu Khe Thai, Alfonso Sycip Hsueh Fan-shih, Lim Shu-an, Huang Hai-shan, and other prominent Chinese leaders were detained as prisoners until 1943. Go Kao-ju (KMT), Ang Chin-gee (Communist), Tan Mu-ting, Uy Mien-ta, Chua Pai-kun, Dee Lien-tau, Sy Kao-yu, and Chua Ki-see-all Enemy Resist Committee leaders; Yü I-t'ung, manager of the Chinese Commercial News; Gan Bun-chu, principal of Anglo-Chinese School, were executed by the kempeitai. Chen, Chinese and the War in the Philippines, pp. 20-21.

152. For instance, the Thai government passed a law on September 20, 1938, which raised the resident fee from one hundred to two hundred bahts. It passed in the spring of 1939 a series of acts designed to curb Chinese economic activities and on May 23, 1941, the government issued a royal decree designating northeastern districts as strategically "prohibited areas," barring the Chinese from entering into them. Those already inhabiting there were forced to evacuate. Landon, The Chinese in Thailand, p. 270; Skinner, Chinese Society in Thailand, pp. 229-231; Asahi shimbun, March 7, 1939; C. C. Chang, "Anti-Chinese Campaign in Thai," China Weekly Review XCII (March 30, 1940), pp. 154-155.

153. Thailand was one of the countries in Southeast Asia thoroughly investigated by Japanese military and civilian intelligence agencies and by semi-official and commercial firms. For instance, one report pinpointed the locations of keys, documents, and membership lists hidden in toilet, bed, kitchen of certain houses and schools. The following information is obtained from the sources listed below. Japan, TSKG, Nanyō kakyō $\dddot{i j} \bar{o}$, pp. 11-48; Japan, TSG, Nampō kakyō meibo, pp. 22-24; Mantetsu SJC, Kakyō chōsa ihō I, pp. 48-50; Fukuda, Nanyō kakyō kō-Nichi undō, pp. 340-342; Mitsui Shamushitsu, "Shamu kakyō shuyō jinbutsu ryabuki," pp. 1-9; "Shamu hai-Nichi dantai shirabe kyōsantōkei-no-bu," pp. 1-13; and "Tai kakyō kenkyo dōsei," in Sankō shiryō, No. 69, Mimeo.; Saruwatari, "Taikoku kakyō," SJK.

154. Skinner, Chinese Society in Thailand, p. 244. This observation should be read with some reservation.

155. Ibid., p. 265.

156. Si-kung, January 23-27, 1939; Prachamit, January 26-27, 1939, cited Ibid.

157. Ibid., p. 266.

158. The capitulation of the cities caused consternation, because 60 per cent of the ThaiChinese originally came from the Ch'aochow-Swatow area.

159. Saruwatari, "Taikoku kakyō," SJK, pp. 77-78.

160. Ibid., p. 79.

161. Ibid., pp. 79-80; Mantetsu SJC, Kakyō chōsa ihö I, p. 52; Landon, The Chinese in

Thailand, pp. 285ff.; Skinner, Chinese Society in Thailand, p. 267.

In early June, Ch'en Wen-t'ien, chairman of the Thailand chapter of the Hua-ch'iao General Mobilization Association organized by Wu T'ieh-ch'eng, was sentenced to a six-year term in prison.

162. Saruwatari, "Taikoku kakyō," SJK, pp. 81-82; Mitsui Shamushitsu, "Tai kakyō kenkyo dōsei," pp. 3-4.

Landon said the twenty-five schools were closed during the months of April and July, 1939. Skinner, quoting Si-kung (August 27, 1939), said that one of the raids produced a KMT membership list containing ten thousand names.

163. Saruwatari, "Taikoku kakyō," SJK, p. 81.

164. Skinner, Chinese Society in Thailand, p. 267; Landon, The Chinese in Thailand, pp. 278, 288; Virginia Thompson, The New Siam (New York: The Macmillan Co., 1941), p. 122; Saruwatari, "Taikoku kakyō," SJK, p. 83.

165. Saruwatari, “Taikoku kakyō,” SJK, pp. 80, 83.

166. $\$ 2,400,000$ was contributed and sent to China between November, 1938, and April, 1939. Landon, The Chinese in Thailand, p. 288.

167. Siam Chronicle, July 24, 25, 1939, cited Ibid., p. 288.

168. Bangkok Chronicle, November 22, 1939; Nankyō tsüshin, November 24, 1939. 
Landon writes that the assassination occurred on November 23. I prefer to rely on the local date.

169. Landon, The Chinese in Thailand, p. 153.

170. Mitsui Shamushitsu, "Shamu kakyō shuyō jinbutsu ryakuki," p. 203.

171. A Töa Kenkyüjo study of the Thai-Chinese identified $\mathrm{Yi}$ as belonging to the Wang Ching-wei faction, quoted in Mantetsu TKC, NKS I, p. 226.

172. An immediate effect of the events in 1939 was an exchange of letters between Chiang Kai-shek and Luang Phibun in late November. Chiang requested Phibun to give Chinese citizens full protection of lives and property and to permit them to engage in their lawful pursuits without molestations. In reply, Phibun promised protection of the lives and property of "good" Chinese residents as well as to permit them to engage in lawful pursuits in the Kingdom. Bangkok Chronicle, December 7, 1939.

173. Saruwatari, "Taikoku kakyō," SJK, p. 85.

174. Ibid. There were, however, a few incidents that were believed to be Communist inspired, such as a great fire in Bangkok (August 6), murders of a Taiwanese and a Chinese (August 20 and September 8), and a threatening letter mailed to the Mitsui Bussan Office (August 5).

175. Bangkok Chronicle, November 22, 1939.

176. Ibid., January 1, 1940; Chang, "Anti-Chinese Campaign in Thai," China Weekly Review (March 30, 1940), pp. 194-195.

177. Skinner, Chinese Society in Thailand, p. 270.

178. Ibid.; Chung Yüan Pao, December 14, 1940, cited in Töa nisshi II, p. 609. Nami Shūdan Shireibu, Kakyō sōkin kingaku no hyōka to sono yüchi kyūshū seisaku, 1941, pp. 35, 40. Marked "Top Secret." Mimeo. Hereafter, Nami Shūdan Shireibu, Kakyō sōkin kingaku hyōka. The Nami Shudan was the code name for the Japanese army that occupied South China.

179. Ichikawa, Tōyō Gakuhō LI, No. 2, p. 13.

180. Chung Yüan Pao, July 23, October 11, 17, 24, 30, November 7, 1940, cited in Töa nisshi II, pp. 607-609. In these months, Thai-Chinese donated money to the government in the show of their support for regaining the territory lost to France and held parties at which a number of Thai dignitaries, including Premier Luang Phibun, showed up.

181. See footnote 152, Chap. II.

182. Ichikawa, Töyō Gakuhö LI, No. 2, p. 14.

183. "Chinese in the South Seas Area Pledge Support in War of Resistance," China Weekly Review XCVI (April 1, 1941), p. 233.

184. General Wu T'ieh-ch'eng was denied entry to Thailand in early 1941, when he was on his trail for soliciting contributions.

185. Asahi Shimbun, April 8, 1941.

186. "China's Fifth Columnists Arrive in Thailand," Far Eastern Survey X (June 2, 1941), p. 120.

187. Fujiwara Iwaichi, F Kikan (Tokyo: Hara Shōbō, 1966), pp. 45-48.

188. Suzuki Taisuke, "Kaisen zenya füun no Bankkoku," in Nippon no Kimitsusen, special issue of Shükan Yomiuri (December, 1956), p. 65. Interview with Ichikawa Kenjirō, September 22, 1968.

Ichikawa said that Chang "got along very well with the Japanese military commander in Thailand [General Nakamura Aketo] during the occupation years."

189. Koshiba Naosada, Capt., "Kaisen zenya no Suwatō," Taikoku ni okeru Kaigun no ichi kakyō kōsaku (June, 1968), pp. 26-27. Unpublished.

190. Saruwatari, “Taikoku kakyō,” SJK, p. 79.

191. Virginia Thompson and Richard Adloff, The Left-Wing in Southeast Asia (New York: Sloan, 1950), p. 58.

192. Tanaka Takeshi, "Taikoku kara mita Nanyō kakyō," Yösukō II, No. 12 (December, 1939), p. 43; Japan, Gaimushō Ajiakyoku, [Shōwa] 12-nendo shitsumu hōkoku, p. 914.

193. Skinner, Chinese Society in Thailand, pp. 244-246.

194. Harada Genryū, "Futsuryō Indoshina kakyō," SJK, pp. 181, 184; Yokohama Shōkin

Ginkō Gaikokuka, Futsuin ni okeru kakyō (Yokohama: Yokohama Shōkin Ginkō), p. 48,

Mimeo.; Fukuda, Nanyō kakyō kō-Nichi undō, p. 347.

195. Fukuda, Nanyō kakyö kō-Nichi undō, p. 348.

196. Yokohama Shōkin Ginkō, Futsuin ni okeru kakyō, p. 8; Harada, "Futsuryō Indoshina kakyō," SJK, pp. 158, 183.

197. See Chap. III.

198. Taiwan Shireibu, Futsuin jōhō No. 2, Kakyō jōhō to gomu mondai, August 5, 1939, Rikushi-Ju Mitsu Dai Nikki CIII, 1939, No. 136, Part 2, Archives of the Japanese Army, Navy, 
and other Government Agencies, 1868-1945, Reel 113. Microfilmed. Marked "Top Secret." Hereafter, RJMDN, Army, Navy Archives.

199. Ichikawa, Tōyō Gakuhō LI, No. 2, p. 12; Nanshi Chōsakai [hōkoku], March 27, 1941, No. 1239. Marked "Secret."

200. Yokohama Shōkin Ginkō, Futsuin ni okeru kakyō, pp. 15-18; Harada, "Futsuryō Indoshina kakyō," SJK, pp. 161-162; Ōya, Futsuin seifu no en-Shō seisaku wo miru, pp. 43-45. 201. Sekai Jōsei Chōsa Iinkai, Rinsen taiseika no Nampō shokoku (Tokyo: Minami Manshū Tetsudō Kabushiki Kaisha Tōa Keizai Chōsakyoku, 1941), pp. 17-18; Fukuda, Nanyō kakyō kō-Nichi undō, p. 291.

202. Nanshi Chōsakai [hōkoku] from Hanoi, March 27, 1941, No. 1239.

203. Harada, "Futsuryō Indoshina kakyō, SJK, pp. 182-183; Cf. Ōya, Futsuin seifu no enShö seisaku wo miru, pp. 5-8; figures taken from Bulletin que de I'Indochine indicated an in crease in volume of freight in 1938. Even after the Japanese stationed troops in Northern French Indochina, Chinese continued boycotting and agitating against Japan. Sekai Jōsei Chōsa Iinkai, Rinsen taiseika no Nampō shokoku, pp. 17-18; Satō Junzō, Tai, Futsuin ni okeru sendensen (Tokyo: Nippon Indoshina Kyōkai, 1941), p. 45; Negishi Tadashi, Kakyō shūki (Tokyo: Asahi Shimbun, 1942), p. 123; Yomiuri Shimbun, August 7, 1941.

Satō was a research and intelligence officer of the Ministry of Foreign Affairs. He returned from a trip to Thailand and French Indochina in March, 1941.

According to Satō's report, Consul Yin Feng-tsao, the Chung Kuo Jih Poh and the Min Poh were reportedly active in disseminating anti-Japanese propaganda.

204. Bernard B. Fall, The Two Viet-Nams. A Political and Military Analysis (New York: Frederick A. Praeger, 1963), pp. 97-98; McLane, Soviet Strategies, p. 220.

205. Taiwangun Shireibu, Futsuin jōhō No. 2, Kakyō jōhō to gomu mondai, RJADN, CIII, 1939, No. 136, Part 2, Army, Navy Archives. Tanikawa Hidehiko, Tönan Ajia minzoku Kaihö undō-shi (Tokyo: Keisō Shobō, 1969), pp. 120-121.

206. Taiwan, Nampō Kyōkai, Biruma no kakyö, p. 39.

207. Ibid.

208. Ibid., p. 41; Rangoon Gazette Weekly Budget, October 10, 1940, cited in Töa nisshi II, p. 594.

209. Töa nisshi I, p. 601 .

210. Taiwan, Nampō Kyōkai, Biruma no kakyō, pp. 35-36.

211. For instance, the upper-class Chinese in Malaya supported the British position in condemning Russia's attack on Finland in October, 1939. Communist intellectuals and laborers criticized not only the small share in contributions the wealthy Chinese had given in proportion to their wealth, but also attacked the British position in relation to the Soviet-Finnish war. The Philippine Resist-the-Enemy-Committee in Manila resolved to purge itself of the terrorist Youth Blood Soul Corps. And the Burma Hua-ch'iao General Relief Association prohibited individual acrimony among Chinese themselves in newspapers for the interest of unity. Hsin Chung Kuo Pao, April 12, 1941; Kak Min Jit Poh, December 11, 1939; cited in Fukuda, Nanyö kakyö kö-Nichi und̄o, p. 251.

\section{Chapter III}

1. Huang, Hua-ch'iao tui tsu-kuo ti kung-hsien, pp. 199ff.; C.Y.W. Meng, "Overseas Chinese in China's Resistance and National Salvation Reconstruction," China Quarterly IV, No. 4 (Autumn, 1939), pp. 622-623.

2. Fukuda, Nanyō kakyō kö-Nichi undō, pp. 267-268.

3. One hundred twenty overseas Chinese received training at an officer candidates' training school in Kwangsi. Twenty-six technicians from Manila and Cebu returned to China, and twenty-eight Chinese of the Communist Chinese Race Armed Self-Defense Society in the Philippines organized a National Volunteer Corps and returned to China in January, 1938, under the auspices of the Chinese Consul General, in order to join an anti-Japanese guerrilla corps. See Wu T'ieh-ch'eng, "Contributions from Overseas Chinese during the War," China Quarterly V, No. 4 (Autumn, 1940), p. 683; Fukuda, Nanyō kakyō kō-Nichi undö, p. 326.

4. Tan, Nan ch'iao hui-i-lu II, p. 85; Wu, China Quarterly V, No. 4, p. 684. Sin Chew Jit Poh, ed., Sin Chew Shih Nien (Singapore: Sin Chew Jit Poh She, 1941), p. 994.

5. Tan, Nan ch'iao hui-i-lu II, p. 85; Meng, China Quarterly IV, No. 4, p. 623. 268

6. Nanyang Siang Poh, August 2, 1939, cited in Fukuda, Nanyō kakyö kō-Nichi undō, p.

7. Tan, Nan ch'iao hui-i-lu II, p. 87; Cheng, Ch'en Chia-keng, pp. 41-42.

8. Domei dispatch from Hanoi, February 22, 1940; Hong Kong Ta Kung Pao, March 22, 1940, cited in Fukuda, Nanyō kakyö kö-Nichi undō, p. 268. 
9. Tan, Nan ch'iao hui-i-lu II, p. 85.

10. As of May, 1940, about 4,000 volunteers had served in China. See Nampō Kyōkai, ed. "Nampō kakyō no gensei," Nampō nenkan 1943 (Taihoku, Taiwan: Nampō Kyōkai, 1943), p. 20.

11. C. K. Ch'en (Tan Kah Kee), "A South Seas Chinese Report on Burma Road," Pacific Affairs XVI, No. 4 (December, 1941), pp. 464-465.

12. Nanyang Siang Poh, January 1, 1940, cited in Töa nisshi I, p. 171; Huang, Hua-ch'iao tui tsu-kuo ti kung-hsien, p. 227.

13. Tan, Nan ch'iao hui-i-lu II, p. 94.

14. Ibid., II, p. 95; Nanyang Siang Poh, January 1, 1940, cited in Töa nisshi I, pp. 171-172.

15. Ichikawa speculates that one of the reasons why landowners in Ch'aochow suffered so much during the period of the Communist Chinese land reform in 1951-1956 might be attributed to the fact that the Thai-Chinese, a majority of whom were Teochius, did not participate in Comfort Missions and were not receptive to the contribution drive. On the other hand, landowners in Amoy, from which Tan Kah Kee had emigrated, relatively fared well and even benefited from the land reform program and industrialization, because the Chinese from Amoy, under Tan Kah Kee's leadership, contributed more to China during the war. It seems likely that the presence of Tan Kah Kee as a high official of the government might have something to do with the different treatments between the two districts. Ichikawa, Töyo Gakuhö LI, No. 2, pp. 20-21.

16. Nanyang Siang Poh, April 14, 1940, cited in Töa nisshi II, p. 589; Fukuda, Nanyö kakyō kō-Nichi undō, p. 435; Minami Manshū Tetsudō Chōsabu, Senji Shina keizai to kakyō sōkin (Dairen: Minami Manshū Tetsudō Chōsabu, 1942), pp. 75-76. Hereafter, Mantetsu Chōsabu, Senji Shina keizai.

17. William Chang, "South Seas Mission given a Royal Welcome on Visit to China's Capital," China Weekly Review XCII (May 14, 1940), p. 340; Nanyang Siang Poh, April 20, 1940, cited in Töa nisshi II, p. 589.

18. Tan, Nan ch'iao hui-i-lu II, p. 341.

19. Nankyō tsūshin, April 20, 1940; Tōa nisshi II, p. 589; North China Herald, May 22, 1940.

20. Töa nisshi II, pp. 589-590.

According to the Nanyang Siang Poh, the comfort mission and the construction of the pharmaceutical factory were two great projects of NCRGA.

At the second NCRGA meeting, Tan stated that 33,000 yuan had been spent for the construction of the plant. The outbreak of the Pacific War put the end to the project, which was still at the planning stage.

21. Ichikawa, Tōyō Gakuhō LI, No. 2, p. 13.

22. Töa nisshi II, p. 591 .

23. Ichikawa, Töyō Gakuhō LI, No. 2, p. 13.

24. "Chinese Red Cross Medical Relief Corps," Oriental Affairs (August, 1941), p. 90; Meng, China Quarterly IV, No. 4, p. 623; Nankyō tsüshin, February 20, 1940.

25. A Reuters dispatch from Chungking cited in Mantetsu Chōsabu, Senji Shina keizai, p. 104.

For a study of the impact on China's financial position as a result of the Japanese occupation of Southeast Asia, see Mantetsu Shanhai Jimusho Chōsashitsu, Daitōa sensō-Kakyō.

26. Fukuda, Nanyō kakyō kö-Nichi undō, pp. 273-274

27. Ibid., pp. 274-275. The list is a modified form of Fukuda's list.

28. Nan-yang nien-chien 1939, Sec. V, pp. 174-175. A slightly different figure is found in Nami Shūdan Shireibu, Kakyō sōkin kingaku no hyōka, p. 48; Fukuda, Nanyō kakyö kö-Nichi undö, p. 359.

29. The round figures for Thailand and French Indochina suggest that they were estimates.

30. Nami Shūdan Shireibu, Kakyö sōkin kingaku no hyōku, p. 48; Hong Kong Ta Kung Pao, April 17, 1941, cited in Fukuda, Nanyō kakyō kō-Nichi undō, p. 360.

31. Nami Shūdan Shireibu, Kakyō sōkin kingaku no hyōka, p. 49

In 1939 , one hundred yuan was worth US $\$ 30.00$, but it was US $\$ 15.00$ in 1940 at official rate. For a discussion of inflation and devaluation, see Arthur N. Young's books: China and Helping Hand 1937-1945 (Cambridge, Mass.: Harvard University Press, 1963); China's Wartime Finance and Inflation, 1937-1945 (Cambridge, Mass.: Harvard University Press, 1965).

The Chinese government deliberately overvalued the national currency, although it had in fact devaluated, in order to cope with the spiral inflation.

32. Nami Shūdan Shireibu, Kakyō sōkin kingaku no hyōka, p. 49.

33. Tan, Nan ch'iao hui-i-lu II, p. 44; "Nan-yang Hua-ch'iao chiu-kuo yun-tung yü Hua-ch'iao chi-kung," Hua-ch'iao sheng-huo (Kunming), Vol. I, No. 5 (September 18, 1940), p. 24. 
Tan was reportedly dissatisfied with rich Chinese and local-born Chinese who "showed little interest" in patriotic activity. See Nanyang Siang Poh, January 1, 1940, cited in Töa nisshi I, p. 177. This is corroborated by a Köain intelligence report. It said that there were fifteen millionaires in Singapore but only ten of them had bought bonds worth about 350,000 yuan. Jöhö No. 27 (October, 1940), p. 93.

34. Hua-ch'iao chih pien-chi wei-yuan-hui, ed., Hua-ch'iao chih: Tsung chih (Taipei, Formosa: Hai-Wai ch'u-pan she, 1956), p. 489.

35. Hong Kong Ta Kung Pao, January 30, 1941, cited in Japan, Shanhai Nippon Taishikan Tokubetsu Chōsahan, Jükei no senji kokusai to kakyö sōkin (Shanghai: Nippon Taishikan, 1941), p. 25. Marked "Secret."

36. Wu, China Quarterly V, No. 4, pp. 681-682. Cf. Japan, Taiwan Sōtokufu, Gaijibu, Sōkin narabi ni tōshi wo tsüjite mitaru kakyō (Taihoku, Taiwan: Taiwan Sōtokufu, 1943), p. 56; "Nampō kakyō gensei," in Nampō nenkan 1943, p. 20.

General Wu expressed the figure in dollars for the convenience of the English-reading audience, but other sources used the monetary unit of yuan.

37. Hua-ch'iao chih pien-chi wei-yuan-hui, Hua-ch'iao chih: Tsung chih, p. 489.

38. Hong Kong Ta Kung Pao, April 17, 1941, cited in Nami Shüdan Shireibu, Kakyō sōkin kingaku no hyōka, p. 8.

The British authorities restricted the remittances of foreign currency to China after the European war began.

39. Nami Shūdan Shireibu, Kakyō sōkin kingaku no hyōka, p. 47.

40. Young, China's Wartime Finance and Inflation, p. 16, Table 3.

41. See Table 7, p. 133.

42. Mantetsu SJC, Kakyō chösa ihö I, p. 83. The figures were taken from a report published by the NCRGA.

43. Tan, Nan ch'iao hui-i-lu II, p. 44; Nanyang Siang Poh, January 1, 1940, cited in Töa nisshi I, p. 177.

44. Fukuda Shōzō, Kakyō keizai ron (Tokyo: Ganshōdō Shōten, 1939), p. 98.

45. Chun-hsi Wu, Dollars Dependents and Dogma. Overseas Chinese Remittances to Communist China (Stanford, California: Hoover Institute of War, Revolution and Peace, 1967), p. 16.

46. See F. C. Remer, Foreign Investments in China (New York: The Macmillan Co., 1933). Tōa Kenkyūjo, ed., Rekkoku tai-Shi tōshi to Shina kokusai shüshi (Tokyo: Jitsugyō no Nippon Sha, 1943); Wu, Dollars Dependents and Dogma.

47. Töa Kenkyūjo, Rekkoku tai-Shi töshi, pp. 241-242; Mantetsu Chōsabu, Senji Shina keizai, pp. 4-5.

A postwar UN study put it 232 to 420 million yuan for the 1931-1936 years. Economic Survey in Asia and the Far East (United Nations, 1950), p. 59, cited in Wu, Dollars Dependents and Dogma, p 198, 2n.

48. Mantetsu Chōsabu, Senji Shina keizai, pp. 2-3.

The above Tōa Kenkyüjo's study gives 2,727,000,000 yuan excess in imports, of which remittances covered $1,633,000,000$ yuan during the five years from 1934 to 1938 inclusive. Rekkoku tai-Shi töshi, p. 245.

49. Remer, Foreign Investments in China, p. 189.

50. Mantetsu Chōsabu, Senji Shina keizai, p. 5.

51. Ishihama Chikō [Tomoyuki], Jükei senji taisei ron (Tokyo: Chūo Kōron Sha, 1942), p. 210; "Shina to kakyō no shokankei," Töa XIII, No. 10 (October, 1940), p. 69.

52. [Kaigun] Gunmukyokuchō to Amoi Tokumubuchō, March 1, 1939; Kōain Sōmubuchō to [Kaigun] Gunreibujichō, June 13, 22, 1939, in [Kaigun] Gunreibu, Shöwa 12 nendo ikō kyü-Shina dōkō. Marked "Top Secret."

53. Japan, Taiwan Sōtokufu Gaijibu, Sōkin narabi ni tōshi wo tsüjïte mitaru kakyō, pp. 6166; Koite Nagato, "Kakyō sōkin sōtatsu no genjo," Nanshi chōsa shiryō shüroku III (Taihoku, Taiwan: Taiwan Ginkō, 1940), p. 42. Marked "Secret." Kenkyū shiryō III, No. 7 (July, 1940), p. 64; Huang Yin-sheng, "Shōwa 15-nendo ni okeru kakyo kunimoto sōkin gaiyōo," Töyō XLIV, No. 3 (March, 1941), pp. 41-42; Nanshi Chösakai [Hōkōku] from Swatow, February 22, 1941, No. 1229. Marked "Secret."

54. Koshiba, Kaisen zenya no Suwatō Taikoku, p. 38.

55. Ma Ch'ao-chün gave the 600 million figure for 1937 at a reception in the honor of Aw Boon Haw on February 26, 1941. Mantetsu Chōsabu, Senji Shina keizai, p. 23; Japan, Jōhōkyoku, Nanyō kakyō gaikan, p. 66.

56. Chin-jung Shang-yeh Pao, July 5, 1939, cited in Mantetsu Chōsabu, Senji Shina keizai, pp. 15,17 . This is corroborated by a Chinese source. See Wei Yu-fei, "Chih-na chan-shih kuochi shou-chih p'ing-heng," in Ts'ai cheng P'ing-lun III, No. 1, cited Ibid., p. 17.

57. Hong Kong Ta Kung Pao, April 5, 1940, cited Ibid., p. 15. 
One Chinese economist, however, maintained that it was not a healthy way to balance the deficit with overseas Chinese remittances since "most overseas Chinese were wage workers, whose income fluctuated in accordance with changes in world economy." Wei, Ts'ai-cheng P'ing-lun III, No. 1, cited Ibid., p. 18.

58. Mainichi Shimbun (Shanghai), January 7, 1940.

Traditionally, remittances increased after Chung-ch'iu festival (August 15). The outbreak of the European war, coinciding with the post-Chung ch'iu festival season, might have contributed to an increase in capital flow from abroad.

59. Nami Shūdan Shireibu, Kakyō sōkin kingaku no kyōka, p. 14; Young, China's Wartime Finance and Inflation, p. 360.

60. Nami Shūdan Shireibu, Kakyō sōkin kingaku no kyōka, p. 14; Young, China's Wartime Finance and Inflation, p. 360.

61. Ta Chen, Emigrant Communities in South China, p. 70. See p. 192, 57n.

62. Kung Hsiang-hsi, "China's War-time Finance in 1939," China Quarterly V, No. 2 (Spring, 1940), p. 186; Ishihama, Jükei senji taisei ron, p. 211.

63. Wu, China Quarterly V, No. 4, p. 686.

64. Meng, Ibid., IV, No. 4, p. 622.

65. Ta Kung Pao, April 17, 1941, cited in Nami Shūdan Shireibu, Kakyō sökin kingaku no hyōka, pp. 7, 14.

66. Yuan Mei-yin, K'ang-chan-ssu-nien lai chih ch'iao-hui, n.p., cited in Japan, Shanhai Nippon Taishikan, Jükei no senji kokusai, p. 24.

My estimate, based on the compilation of figures in Table 7 , is about six billion yuan.

67. A most comprehensive and realistic study on China's wartime economy and its capability to wage the war is found in a ten-volume work compiled by Mantetsu Shina Kōsenryoku Chōsa Iinkai, particularly volumes IV, V, VI, VII, VIII, and IX. They are marked "Top Secret." 205.

68. Barnett, Far Eastern Survey V, No. 10, pp. 112ff.; Imura, Rekkoku no tai-Shi töshi, p.

Chiang Kai-shek urged Shanghai merchants and businessmen to invest their idle capital in hinterland industrial development. It would help, he said, to implement the government's economic construction plans and promote the development of natural resources. Domei dispatch, October 20, 1939.

69. Tōa jōhō, No. 319 (February 15, 1939), p. 3.

70. Meng, China Quarterly IV, No. 4, p. 629; "Nanyō kakyō no saikin no dōkō," Kokusai keizai shühö XXII, No. 36 (September 6, 1941), p. 18.

71. Meng, China Quarterly IV, No. 4, p. 629; Ta-lu Hsin-Pao, October 8, 1939, cited in Nami Shūdan Shireibu, Kakyō sōkin kingaku no hyōka, p. 51.

Article Three of the Act reads:

"In any economic undertaking, an overseas Chinese who invests more than 60 per cent of the total capital investment of an enterprise shall be entitled to apply to the Ministry of Economic Affairs for the following privileges: (1) Administrative and technical assistance and guidance; (2) Exemption or reduction of taxes; (3) The use of transportation facilities and reduction in transportation charge; (4) The use of public land; (5) Guarantee for the capital investment and an interest payment; (6) Government subsidy; (7) Meritorious prize."

72. Chungking Ta Kung Pao, October 30, 1940, cited in Mantetsu Chösabu, Senji Shina keizai, p. 73.

73. Ibid., p. 74.

74. Chungking Ta Kung Pao, October 30, 1940, cited Ibid., p. 73; Tan, Nan ch'iao hui-i-lu II, pp. 126-127; Chung Yüan Pao, October 9, 1940, cited in Töa nisshi II, p. 573; Fukuda, Kakyō keizai ron, pp. 453-457; "Nampō kakyō no gensei," Nampō nenkan 1943, p. 134; Ishihama, Jükei senji taisei ron, pp. 215-216; Töa jumpö, No. 395 (April 15, 1941); Kokusai keizai shūhō XXII, No. 36, p. 18; "Jūkei no kakyō taisaku wo miru," Kokusai keizai shühō XXIII, No. 45 (November 7, 1942), p. 18.

75. Chin-jung Shang-yeh Pao, May 14, 1941, Cheng Yen Pao, February 15, 1941, cited in Mantetsu Chōsabu, Senji Shina keizai, p. 74.

76. Nami Shūdan Shireibu, Kakyō sōkin kingaku no hyōka, p. 52.

77. Cited in Mantetsu Chösabu, Senji Shina keizai, pp. 74-75.

A figure of 800 million yuan was reported to have been invested by the end of 1940 . This figure in effect corroborates a total of the figures for 1939 and 1940 , which is 796.4 million yuan. China Weekly Review XCVI (March 1, 1941), cited Ibid., pp. 34, 74

78. Shanghai Evening Post, November 1, 1941, cited Ibid., pp. 34, 36.

79. Mantetsu Chōsabu, Senji Shina keizai, p. 74.

80. Ibid., pp. 90,98 .

81. Ibid., p. 98 . 
82. Ibid., pp. $89-90$

83. I am indebted to C. F. Remer for this study of relatives and link relatives. See his $A$ Study of Chinese Boycotts.

84. In the Philippines, a systematic boycott did not start until late February, 1938. See Chapter II.

85. Cf. Skinner, Chinese Society in Thailand, p. 244; Fukuda, Kakyō keizai ron, pp. 489. 490; Japan, Gaimusho Tsūshōkyoku, Kaigai tsūshō jōhō, No. 3, 1939, pp. 4-5; Ōshima Shigeo, "Shingapōru wo chūshin to suru kakyō no jihen ni taisuru dōsei to sono taisaku," Taiwan jōhō, No. 233 (April, 1939), pp. 36-37; Töa jōhō, No. 274, pp. 23-25; Kokusai jōhō, No. 540, pp. 60-61.

86. Cf. Jean Chesneaux, Contribution a l'Histoire de la Nation Vietnamienne, p. 227, cited in Tanikawa, Tönan Ajia minzoku kaihō, p. 126.

87. The price of tin dropped from $\$ 137$ in March, 1937 , to $\$ 93$ in September of the same year. Rubber price also declined from $45 \notin$ in April, 1937 , to $22 \phi$ in November, 1937 . The decline in prices of these basic export commodities had direct relation upon the purchasing power of native peoples in Southeast Asia.

Malayan State governments passed laws in January, 1938, and July, 1939, to limit the importation of Japanese textiles and other goods. The Netherlands East Indies government also imposed a quota system on import goods, and Thailand, the Philippines, and French Indochina raised tariffs in order to protect their own industries.

88. M.S.F. [Miriam S. Farley], "Anti-Japanese Boycott Effectiveness in South East Asia," Far Eastern Survey VII, No. 23 (December 7, 1939), pp. 284-285.

89. Figures used in the following monthly statistics are taken from Japan's Finance Ministry publication, Monthly Return of the Foreign Trade of Japan, unless otherwise noted.

90. Japan, Ōkurashō, Nippon gaikoku bōeki shihanki hyō, dai-ichi, dai-ni shihanki (Tokyo: Ōkurashō, 1937).

91. See footnote 124 , Ch. I.

92. Official Annual Report of Insular Collector of Customs, 1936, 1937, 1938; Year Book of Philippine Statistics 1940.

93. According to findings of the Japanese Chamber of Commerce in Manila, unrefined U.S. cotton cost 5.80 pesos per 12 yards against 6.40 pesos for Japanese cotton. Refined U.S. cotton was 6.80 pesos against 7.40 pesos for Japanese cotton. Moreover, Japanese cotton was not competitive with American cotton, which was far superior in quality. Nanyō XXIV, No. 2 (February, 1940), p. 155. Nanshi Chösakai [hōkoku] from Manila, March 6, 1941, No. 1234. Marked "Secret."

This report is based on a study conducted by the Japanese Chamber of Commerce at Manila that Chinese stores were switching to American goods from Japanese merchandise, because they could make a reasonable profit by handling the quality American products, instead of risking the danger of dealing in Japanese manufactured goods.

94. Nanshi Chōsakai [hōkoku] from Manila, March 6, 1941, p. 1234.

95. See footnote 154, Chap. II.

96. Since Thailand provided a free market for cotton goods, Japanese producers flooded the market with dumping. By a government policy, the Japanese cotton textile industry operated under the link system. Cotton manufacturers, in order to get a new quota for raw cotton from the government, had to export products within a limited period.

97. For instance, Japanese enamelled ironwares and nails were unable to compete with Chinese products imported from Shanghai, as the latter were about 20 per cent cheaper and the quality was comparable with the Japanese product. Chinese were able to sell at a cut rate because the devaluation of the yuan started in 1938. Nanyō Kyōkai, Nanyō keizai kondankai hökokusho, p. 85.

In the cotton market, Japan had lost 15 per cent in exports by 1939 , while China had gained 15 per cent by the same year.

98. The French government also raised the tariff wall against Japanese tea and Aji-no-moto, monosodium glutamate.

99. China used this export channel because import duties on goods from Hong Kong to French Indochinese ports were lower.

100. The French statistical figures contradict with the Japanese figures cited on p. 143, Chapter III. This discrepancy is owing to a difference in a matter of what the French and the Japanese considered imports and exports. For instance, the French regarded reeled cotton threads exported by the United States but carried in Japanese ships as imports from Japan. The Japanese did not consider them as her exports to French Indochina. 


\section{Chapter IV}

1. Japan, Gaimushō, Gaikō mondai ni kanshi Kokkai ni okeru shitsugi ōtōshū (Tokyo: Gaimushō, 1941), n.p.

2. Yong Ching Fatt, "A Preliminary Study of Chinese Leadership in Singapore, 1900-1941," Journal of Southeast Asian History IX, No. 2 (September, 1968), pp. 272, 277.

3. Nanshi Chösakai [hōkoku] from Manila, March 5, 1941.

4. Interview with former Japanese military administrators.

5. Japan, Dai 25-gun Gunsei Shireibu, Kakyō kōsaku jisshi yöryō, April 19, 1942. Marked "Secret."

6. In 1963, remains of Chinese were excavated in Singapore, said to be those massacred in 1942, by the Japanese military. Singapore Chinese threatened to boycott Japanese goods unless a satisfactory settlement could be reached with the Japanese government to clear the "Blood Debt." The embarrassed Japanese government settled the question in October, 1966, by offering Singapore $\$ 16.5$ million. New York Times, October 26, 1966.

Furthermore, Premier Satō Eisaku of Japan agreed in September, 1967, to loan two freighters without charge to the Malaysian government for the settlement of the "Blood Debt" with the Malaysian government. The "Blood Debt" issue was settled in late 1968, with the delivery of two ships to Malaysia. 


\section{Appendix}

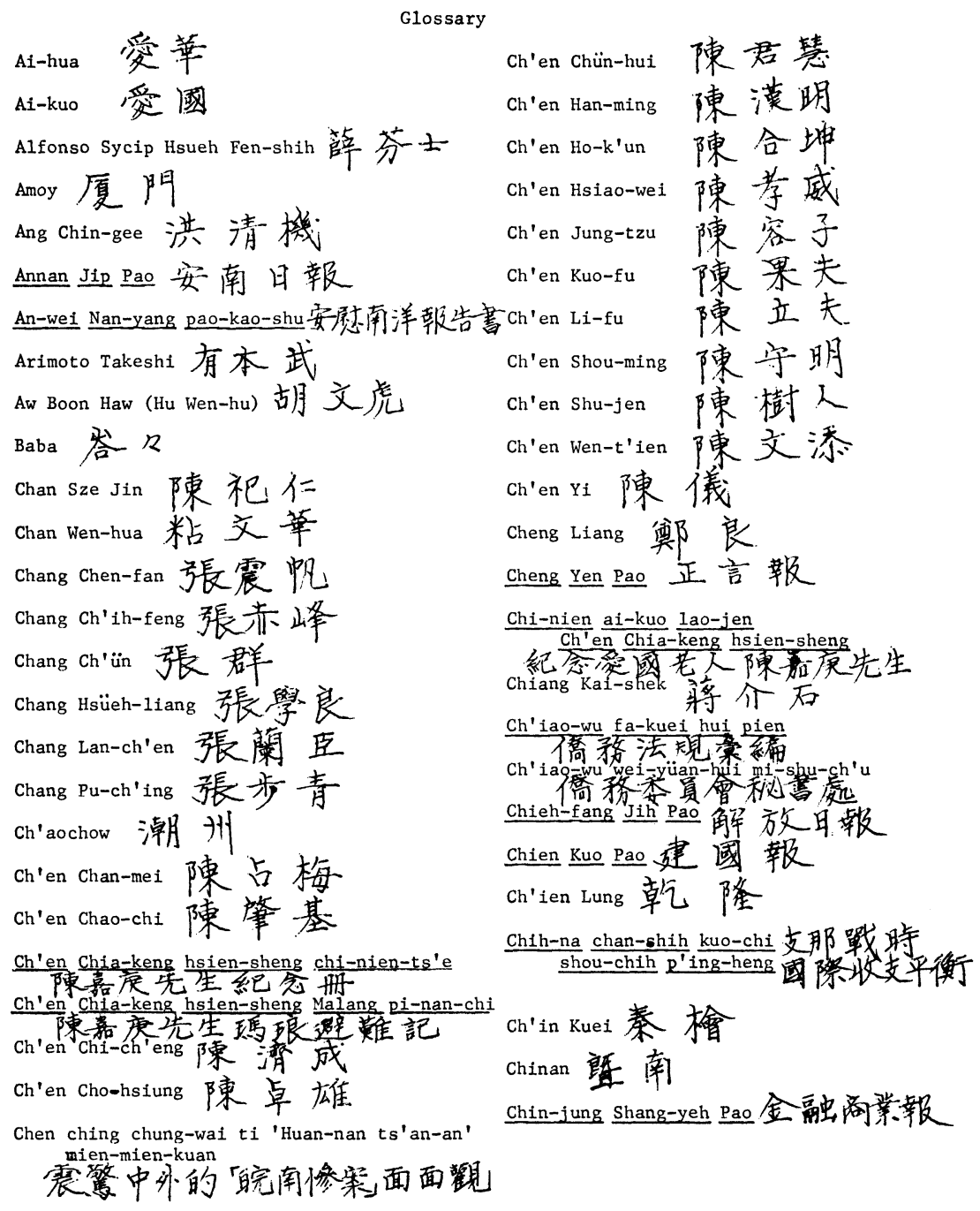


Chin shih chi 近事記 Ching Kee Sun 苞紀宸 Ch'iu Cheng-t'ou 红正頭 Ch'iu Yüan-jung 壬元㮡 Ch'iungchou 涗 州 Chou Chao-ch'un 周肇春 Chou Chih-kang 周之槙 Chou En-1ai 周 恩來 Chow Hean Swee 周南文瑞 Chu Chi-hsing 朱繼興 Chu Chia-hua 朱家䮦 Chu Teh 朱 德 Chua Ki-see 蔡及時 Chua Pai-kung 蔡派恭 Ch'üun Min Jih Pao 全民日報 Ch'üanchow 泉 洲 Chuang Ming-1i 社 明理 Chung Hua Min Pao 中羍民報 Chung-hua Ch'üan-kuo Hua-ch'iao Lien-ho-hui 中草全國等㒀联合會 Chungking 重㦄

Chung-ch'iu 仲秋

Chung-kuo Kuo-min-tang nien-chien 中國民党年鑑

Chung-kuo Kuo-min-tang shih 中國國党更

Chung Kuo Jih Pao

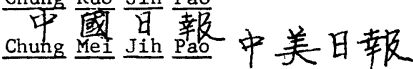
Chung Nan 中南
Chung Shan ㅂueh She 中山祭社 Chung Yüan Pao 中原報 Co Yu-ch'ao 許友超 Cua Chün-ti 柯俊智 Dai Nippon 大 可本 Dee c. Chuan 李清泉 Dee Huanchay 李 焕彩 Dee Lien-tau 李遇朝 Domei 同盟

Feng Ts'an-1i 溤燦利 E Kikan $F$ 機 関 Fei-1ü-pin yü Hua-ch'iao-shih-chi ta-kuan

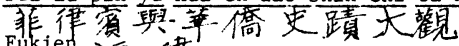
Fukien 福 建

Gaikōihō 外交时郝 Gaimusho Jōhōbu 外務省情報部 Gaimushö Nanyōka 外訝省南洋課 Gaimushö Tsūshōkyoku 外務少通商局 Gan Bun-chu 颜文初 Go Chun-ming 笑 宗明 Go Co-lai 觉苟棸。 Go King P'un 觅金䏇 Go Kao-ju 受九如 Go Puan-seng 受半生 Gunji Kiichi 郡司喜一 Haikow 海四 Hainanese海南人 


\begin{tabular}{|c|c|}
\hline Haiphong 海防 & Hua Hsi 華西 \\
\hline Hakka 客家 & Hua Hsien $\underline{\mathrm{Jih}} \underline{\mathrm{P}}$ \\
\hline 河 & Hua-k'ang 笋 \\
\hline Hara Shigeharu 原繁洽 & Hua Sheng Jih Pao \\
\hline Hidaka Shinrokurō日高 & Hua Sin Jip Poh \\
\hline Higashi Indo ippoo 東 & Huang Chi-sheng \\
\hline Hochi Shimbun 䇉知新聞 & Huang Chung-chi 黄重 \\
\hline Ho Chin Minh 胡袁明 & Huang Hai-shan 黄 =' \\
\hline Hokkien 福建人 & Huang Hsiu-feng 黄 \\
\hline Ho Pao-jen 何㷛不 & Huang Hun 黄 魄 \\
\hline Hо Ying-ch'in 何應 & Huang Hua Kang 㭟花風 \\
\hline Hsiao Chi-shan 重吉珊 & Huang Liang 黄亮 \\
\hline Hsiao Fo-ch'eng 㴋伟成 & Huang Neng-jung黄 \\
\hline Hsieh Teh-ch'ao 謝德超 & Huang Tan-chi \\
\hline Hsien Tai Jit Poh 現代月報 & Huang T'ien-chüeh黄天㸹 \\
\hline Hsin Chung Kuo Pao 新中國狼 & Huang Yi-t'ang 黄谷堂 \\
\hline Hsin Kuo Min Jit Poh 新國民日畭 & Huichou 惠州 \\
\hline Hsing Tao Jih Pao 星俱耳赤 & Hung Yüan-yüan 洪淵源 \\
\hline Hsü Ching 許 敬 & Ide Kiwata 井手季和 \\
\hline Hsü Kuan-chih 許 辟見 之 & I-ho-hsüan 恰和軸 \\
\hline Hsü Shih-ying 徐地“英 & Ishihara 石原 \\
\hline Hsüchow 徐 训 & Ishizawa 石澤 \\
\hline Hsueh Min-1ao 餢敏 & Isoya Gorō礒谷伍郎 \\
\hline Hua-ch'iao Chi-k'an 草侉季刊 & Itagaki Yoichi 板埴奥一 \\
\hline Hua-ch'iao Jih Pao 繁垌日報 & Jen Yeh-yüan 任芽. \\
\hline 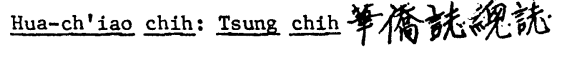 & 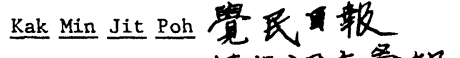 \\
\hline 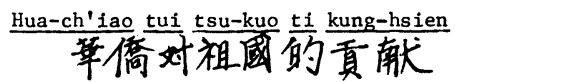 & 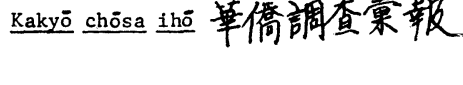 \\
\hline
\end{tabular}


Kanan Ginkö笋南银行

K'ang-Chan ssu-nien 1 ai chih ch'iao-hui

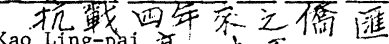

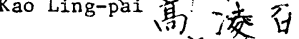
Kao Shih-heng 㶽事恒 Kao Tsung-wu活宗武, Kawamura Saburō河材三郎 Kempeitai 悹安隊 Keng Po 紊竞報

Kihara Jitarō 木原次太郎

Kikakuin 企画院

Köain 然留院

Kong Li Po 公理鿒。

Koshiba Naosada j染道真

Ko Tsu-k'uang 盼 祖瞊

Kow Say Huan 㴑正了 反

Ku Chün-ying 宰俊英

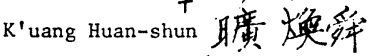

Kueiyang 基陽

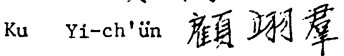

Kung Hsiang-hsi 32 祥㜯

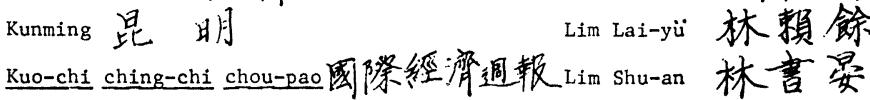

Kuo T'ien 部用

Kwangsi 庴 西

Kwangtung 廣束

Kwang Wah Jip Pao 光萃日靬
Kwee Bok Ai 新博愛

Lan-yi she 影衣不上 Lee Chim Tian 李振殿 Lee Kong Chian李米前 Lee Wee Nam 李傽产 Liao Ch'eng-chih 廖等志 Liang Jui-nan 深寯献 Liang Wei-ch'eng 深傽成 Li-chih she 湡力志社 Li Hai-jo 李海若 Li Hsiao-wu李孝武 Li Pai-ts'ai 李柏材 Li Shui-1i 李水魚里 Li Ssu-yüan 李思溒 Li T'ien-ho李天租 Li Tsung-jen 李宗仁 Lim Boon Keng 林文㦄 Lim Bo Sheng 林謀盛 Lim Han Hoe 林漠河 Lim Keng Lian 林度年 Lim Lai-yü 林粸蜍 Lin Chiang-shih 林江后 Lin Lung-hua 林隆萃 Lin shen 林林 Lin Tse-ch'en 林澤臣 Lin Tso-mei 林作梅 


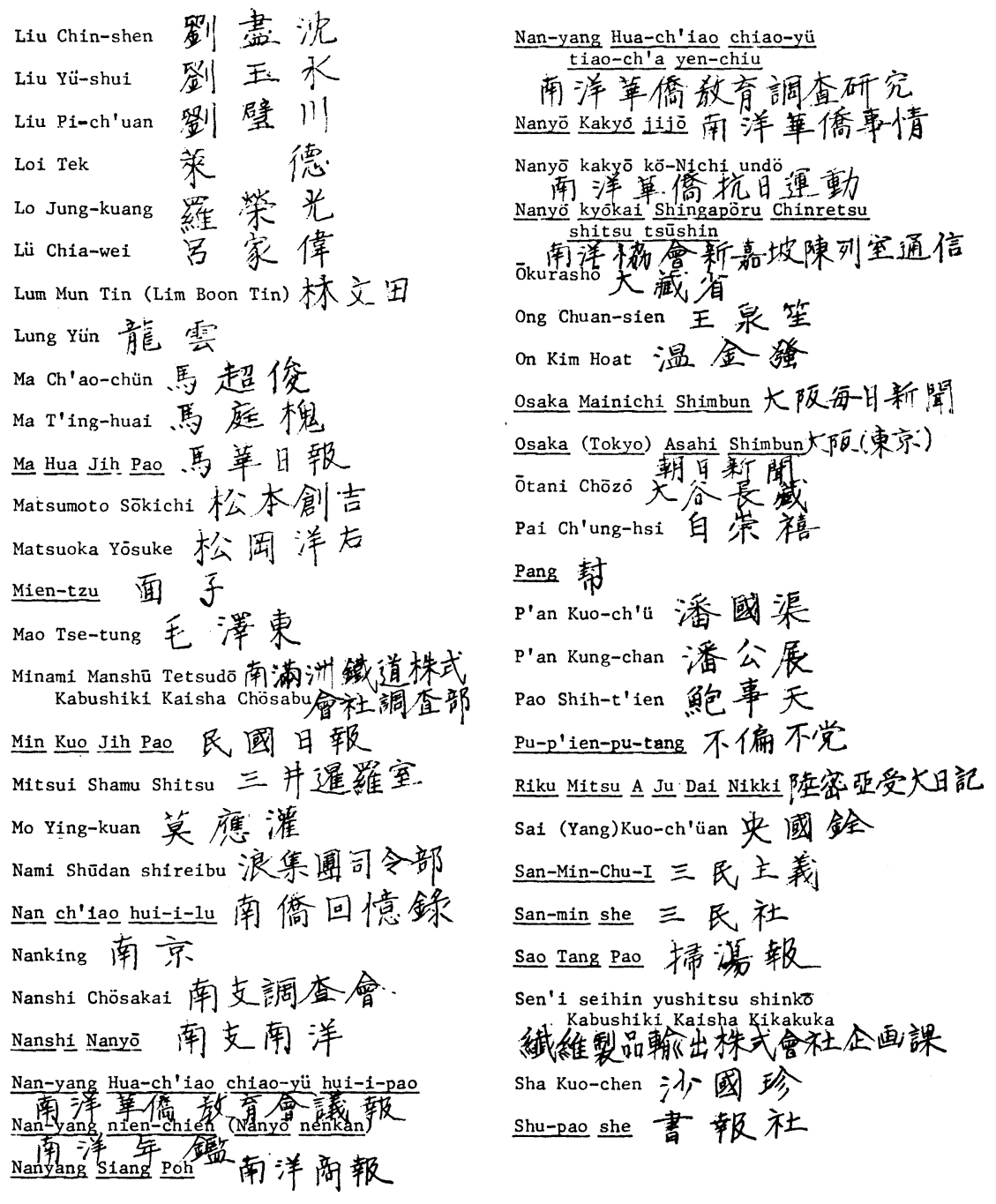




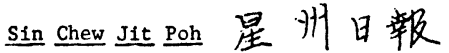
Sin Chew Shih Nien 星州十年 Sin Chung Git Poh 新中日郭 Singkheh 新 客 Sin Po 新 郝 Song ong siang 染胿相 Sook ching 肃清 Su T'ang-jung 彩棠榮 Sugita Ichifi 杉田一次

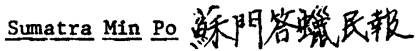
Sun Chen-t'ao 䌽甄。陶 Sun Fo 孫科 Sun Yat-sen 孫逸仙 Sung Che-yüan 案哲元 Sung Tzu-wen (T.V. Soong)宋子文 Swatow 治頭

Sy Kao-yu 施教金居 Sy Yat-sien 施逸生 Ssu-fan 四犯

Ta-chan yü Nan ch'lao大戰舆南僑 Ta-Ch'Ing Lu-1i 大清律例 Ta Kong Siang po 大公商報 Ta uㅡ ㅂsin pao 大陸新報 Taiheiyo 长平洋 Tai Li 戴 等 Tat King-hwa (Te Kin Hua) 戴金革
Tai Kui-sheng (Tai K'uei-sheng)戴愧生 Tai T'ien-ch'ou 戴 天仇 Taierchwang 大場鋽 Taiwan Ginkō 合灣银行

Taiwan Sötokufu Gaijika 会㳪總督府外事課 Kabushiki Kaisha 合溚拓植株式會社 Takumukyoku 拓弱局 Tan Cheng Lock 陳楨椂 Tan Chin Hean 挭挀唄 Tan Ean Kiam 陳延謙 Tang-hua chiao-yü 党化教育 Tan Kah Kee (Ch'en Chia-keng) 陳嘉庚 Tan Mu-ting 陳穆鼎 Tan Samto 陳三多 Tan Unliong 陳温良 Tao-nien 悼 念 Teochiu 潮 H Teo Eng Hock (Chang Yung-fu)張乘福 Thien Sung Iip po 天整日靯 Thio Thiam Tjong 张添聭 Tiao Tso-ch'ien 力作諡 T'ien uㅡ Min Pao 天革央赫 Ting Pe'i-lun 丁培偏 Ting Pe'i-tz'u 丁培慈 IIong Hwa Tiang 中茾领 


\begin{tabular}{|c|c|}
\hline Tjong Ah Fie 正毅衛 & Wang Kung-ch'üan 王公權 \\
\hline Tjong See-gan SI & Wang Ming (Ch'en Sha \\
\hline Töa Döbun Shoin Daigaku 車 & Wang Shih-chieh \\
\hline 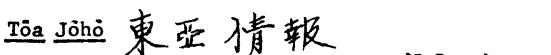 & Wang Tso-sheng 王作 \\
\hline Töa Keizai Chösakyoku東严经滑調查局 & Wang Yen-chih 王 之 \\
\hline Töa Kenkyûjo東舞研究所 & Wee Swee Teow 黄 瑞朝 \\
\hline 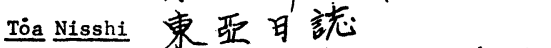 & Wen rit-ho 温裕和 \\
\hline Tokyo Nichi Nichi Shimbun & Wu Pi-yen \\
\hline Toyō Gakuhō 東洋，量 & Wu T'ieh-ch'eng \\
\hline Ts'a1-cheng $\frac{P^{\prime} \text { ing-1un }}{-t}$ & Yang Kheng weng 揚 \\
\hline Ts'ai Chih-fang & Yang Kuang-sheng (Kuangson Young)揚光泩 \\
\hline Ts'al T'Ing-kai & Yang Kuo-ch'in 揚四群 \\
\hline Ts'an-cheng-yüan & Yang Sheng 生 \\
\hline Tseng Chung-ming 筸 & Yang Sung 揚送 \\
\hline Tseng $T$ 'ing-chüian (Justo $\mathrm{C}$ & Yang-t'ou kou-ju 羊顽狗肉 \\
\hline Tseng T'ung-ch'un 僧 & Yao Pai-1ung 姚伯龍 \\
\hline Tsinan 淯 南 & Yeh Kung-ch' ao 梯 \\
\hline Tzuchung 凘中 & Yeh I'ing 莠 掘 \\
\hline Tsurumi Yüsuke 鶴 & Yeh Yü 芽 餘 \\
\hline T'ung Meng Hui 同盟 & Yenan 延安 \\
\hline I'ung-teh shu-pao she 同德書報杜 & Yen Tzu-chün 顔子俊 \\
\hline 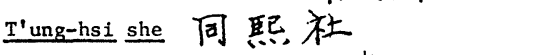 & Yi Kuang-yen 蟈光炎 \\
\hline Uchiyama Kiyoshi 付出清 & Yin Feng-tsao 尹国澡 \\
\hline Uy Mien-ta 黄 念打 & Yokohama Shökin Ginkö横演正金銀行 \\
\hline Wang Cheng-t'ing 王正廷 & Yoshida Tan'ichiró吉田乎一郎 \\
\hline Wang Ching-wei 汪精街 & Yoshizumi Tamegorö 吉住 \\
\hline
\end{tabular}


Yỏsuko 揚子江

Youth Le-hsin she青年隼心社

Yüan Mei-yin 意海因

Yüan Shih-kai 营世凯

Yu ching-chin 揚肈根

Yu Shan-tung 游山東

yü Han-mou 余漠謀

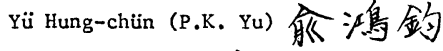

yü I-t'ung 千次同

Yu Khe Thai 揚䧄巷

Yüeh shu pao she 䦎费䇉杜 Yunnan 雲南

Yushitsu Jitensha 


\section{Index}

Act Regulating Overseas Chinese Remittances to the Enemy-Controlled Areas, 1939, 130131

Act to Attract Overseas Chinese Remittances, 1940, 131

Ai-hua Athletic Society, 173(58n)

Ai-hua Musical Drama Society, 173(58n, 69n)

Ai-kuo Bonds. See Bond subscriptions

Alfonso Sycip Hsueh Fen-shih, 43, 92, 140, $166,175(109 n), 187(151 n)$

All Malay District (Fukien) Hua-Ch'iao Relief Fund-Raising Associations, 19

Amoy, 25, 38, 49, 130, 131, 152, 177(135n), 181(35n), 190(15n)

Amoy Liaison Office, Japanese Navy, 131

Ang Chin-gee, 187(151n)

Annam, 102

Annan lit Po (Cholon), 8

Anti-Chinese sentiments: in the Philippines, 51; in Thailand, 51-52. See also AntiSinicism

Anti-Enemy Volunteers' Corps, 173(57n)

Anti-Sinicism, 99, 104, 106

Arimoto Takeshi, 36, 37

Army Ministry of, Japan. See Japan, Government of

Asahi Shimbun, 105, 173(57n)

Assembly for the Support of International Peace, 24

Associations. See individual listings

Aw Boon Haw, 19, 32, 65, 66, 138, 140, 160, $170(24 n), 191(55 n)$

Baba (local-born Chinese), 29, 38, 41, 124, 128-129, 162, 191(33n)

Bandjermasin (Borneo), 33

Bandoeng, 38

Bangkok Chinese Chamber of Commerce, 52 53, 58, 59, 96, 98, 100,101, 102, 105

Bangkok Jit Poh, 8

Bangkok Times, 54

Banishment Ordinance, 73

Bank of Canton, 130

Bank of China, 130, 132

Bank of Communications, 130

Bank of Construction, 139,141

Bank of Taiwan, 36, 180(26n), 181(35n)

Barnett, Robert W., 134, 137

Batavia, 169(7n)

Batavia Chinese Chamber of Commerce, 34

Batavia Hua-ch'iao Charity Committee, 34$36,41,42,86$

Bond subscriptions, 30, 34-35, 60, 160, 175 (113n); Ai-kuo Bonds, 19; National Salvation War Bonds, 43, 125; Gold Bonds, 125; National Defense Bonds, 125

Borneo, 12, 33

Boruneo Shimbun, 175(116n)

Boycott, 2, 3, 18, 43-44, 45, 47-48, 53, 54, $87,88-89,92,98,160,177(135 \mathrm{n})$; boycott declared in Singapore-Malaya, 17; boycott declared in the Dutch East Indies, 36; Chinese difficulty in boycotting, 37, 39, 4041 ; boycott declared in the Philippines, 46 , 193(84n); boycott declared in Thailand, 52, 99-100; boycott in French Indochina, $60,107-108,109$; boycott in Burma, 61

Boycott effectiveness, 141-158; in SingaporeMalaya, 145, 147; in the Dutch East Indies, 143, 145, 149-151; in the Philippines, 145, 151-154; in Thailand, 145-146, 154-156; in French Indochina, 146, 156158

Brimmel, J. H., 74, 81

British, Government of, in Malaya, 18, 20, $22,24,25,27,32,78,81,82-83,171(15 \mathrm{n})$, 172(23n), 182(40n), 184(103n), 191(38n); issued warning, 16, 173(70n); restricted anti-Japanese activities, 20; arrested Communists, 21, 23, 26, 173(57n); Singapore riot, 24-25; Penang riot, 26; relations with Japan, 32-33, 72, 81, 182(51n); policy toward Communists, 72-74; relation with KMT government, $81-82$

Brussels Conference, 45

Burma, 12, 114, 125

Burma Hua-ch'iao General Association for Relief, 110, 189(211n)

Burma Road, 73, 76, 77, 81, 110, 113, 114, $115,118,126$

"Buy-China-Products" campaign, 145, 149, $151,156,157-158,160$

Cambodia, 59, 60

Canton, 25, 61, 67, 79, 130, 131, 137, 148, $152,181(29 n, 35 n)$

Cantonese, 29, 33, 38, 107, 162; rivalry with the Fukienese, 31, 32, 41

Cantonese Chinese, Association of, 23

Canton-Hankow Railways, 138

Capiz, Panay province, 49

Celebes, 12, 33

Central Executive Committee. See Chinese Nationalist party (KMT)

Central News Agency. See Kuomintang (KMT), Government of

Chan Sze Jin, 66

Chan Wen-hua, 27, 173(57n)

Chang Chen-fan, 108

Chang Ch'ih-feng, 97

Changchow-Amoy Railways. See Fukien, province of

Chang Chün, 116, 171(6n)

Chang Hsueh-liang, Marshal, 20

Chang Lan-ch'en, 103, 105, 166, 188(188n)

Ch'aochow, 99, 100, 130, 180-181(28n), 187 $(158 n), 190(15 n)$

Ch'en Chan-mei, 65

Ch'en Chao-chi, 65

Ch'en Chi-ch'eng, 70

Ch'en Cho-hsiung, 121

Ch'en Chun-hui, 70 
Ch'en Han-ming, 17

Ch'en Ho-k'un, 97

Ch'en Hsiao-wei, 121

Ch'en Jung-tzu, 98

Ch'en Kuo-fu, 11, 170(32n)

Ch'en Li-fu, 11, 170(32n), 176(120n)

Ch'en Shou-ming, 56, 96-97, 140, 178(173n)

Ch'en Shu-jen, 120, 176(120n)

Ch'en Wen-t'ien, $187(161 \mathrm{n})$

Ch'en Yi, 75, 77, 80, 182(53n)

Chiang Kai-shek, 3, 11, 15, 16, 20, 29, 42, $43,59,67,68,72,75,76,77,80-81,82$, $109,114,116,150,174(87 \mathrm{n}), 180(27 \mathrm{n})$, $181(29 n), 182(53 n), 183(71 n), 188(172 n)$, $192(68 n)$

Chiang Kai-shek, Mme., 93, 116, 117

Chieh-fang Jih Pao, 184(100n)

Ch'ien Lung, Emperor, 1

Chiengmai, 54, 99

Ch'in Kuei, 67, 179(15n)

China Association for the Construction of Airplanes, 50, 110

China Association for the Promotion of Chinese Goods, 21

China-Burma Cultural Association, 110

China Committee for the Eradication of Inferior Goods, 21

China Expeditionary Army (CEA), Japan, $180(27 n)$

China Foreign Relations Association, Chungking, 78

Chinan University, 10

Chinese Aviation Society, Malay-Singapore, 29, 30

Chinese Buddhist Association for International Visits, 121

Chinese Chamber of Commerce, 15, 52, 57, $113,159,163-164$; relations to Chinese Nationalist Party (KMT), 9. See also individual listings for specific chambers of commerce

Chinese Commercial Press (Manila) 8, 91, $170(24 n)$

Chinese Communist Party. See Communist Party

Chinese Communists. See Communists

Chinese Consulate: at Singapore established, 1 ; in the Philippines established, 1; KMT Consulates General established, 170(30n)

Chinese Cotton Cloth Merchants, Association of, 37, 39, 174(95n)

Chinese Council for Foreign Relations, Hanoi, 107

Chinese Cultural Association, 121

Chinese General Association for the Relief of Refugees, 21, 23, 30

Chinese guild, 24, 45

Chinese Importers' Association of the Netherlands Indies, 36, 174(83n)

Chinese in Batavia massacre, 1

Chinese Moslem Association, 121

Chinese National Liberation Vanguard Corps, $21,22,23,26,173(57 \mathrm{n})$
Chinese Nationalist Party (KMT), 24, 31, 35, $37,39,42,43,47,48,50,53-54,56,58-$ $59,60,66,71,74-83,84,87,96-97,102$, $104-105,106-107,110,122,154-155,159-$ 162, 164-166, 175(109n); Second Party Congress, 3; Overseas Party Affairs, Department of, 3, 6-7, 8, 9; KMT established party machinery in Southeast Asian countries, 3-4; Central Executive Committee, 6, 9; Propaganda, Department of, 6, 7, 8, 71; Organization, Department of, 6; Mass Movement Guidance, Department of, 6; policy toward the press, $8-9$; policy toward chambers of commerce, 9; education policy, 10; Training, Department of, 10; interference resented by Nanyang Chinese, 32; factional strife in the Philippines, 89. 94; Military Council, 114

Chinese New Year, 45, 46, 152

Chinese Race Armed Self-Defense Society. See Communists

Chinese Women's Association for Comforting Fighting Soldiers, 29, 30, 177(143n)

Chinese Women's War Aid Association, 125

Ching Kee Sun, 65, 185(104n)

Ch'iu Cheng-t'ou, 120

Ch'iu Yuan-jung, 41, 65, 175(103n)

Ch'iungchou, 56

Cholon. See Saigon

Chou Chao-ch'un, $180(27 n)$

Chou Chih-kang, $180(27 n)$

Chou En-lai, 76, 81

Chou Yen-sei, 180(27n)

Chow Hean Swee, 65, 172(30n)

Chu Chi-hsing, 109, 140, 166

Chu Chia-hua, 183(71n)

Chu Teh, 76

Chua Ki-see, $187(151 \mathrm{n})$

Chua Pai-kun, 187(151n)

Chuan, Dee C., 50, 63, 64-65, 175(109n, $111 \mathrm{n}), 177(139 \mathrm{n}), 181(29 \mathrm{n})$

Ch'üan Min Jit Pao (Saigon), 98

Chuanchow, 130

Chuang Ming-li, 182(41n)

Chung-ch'iu Festival, 192(58n)

Chung Hua Min Pao (Bangkok), 100

Chung Kuo Council for General Mobilization, $82,83,184(100 \mathrm{n})$

Chung-kuo Jih-pao (Bangkok), 99

Chung Mei Jih Pao, 138

Chung Nan Rubber Company, 139, 141

Chung Shan Hsüeh she (Sun Yat-sen's Society), 90

Chung Yüan Pao, 100

Chungking, 77, 101, 116, 117, 138

Civil Liberties Union, 93

Clannishness. See Nanyang Hua-ch'iao Communities under clannishness

Co Yu-ch'ao, 175(109n)

Colonial Affairs, Ministry of, Japan. See Japan, Government of

Comfort Missions, 115-119, 190(15n, 20n); members selected, 116; arrive Chungking, 
116; mission leaders praise war-time China, 118; Tan Kah Kee, 116-119

Commercial Representative, Office of (Bangkok), 96

Communist Party, 12, 56; Chinese Communist Party, 12, 73, 97, 170(32n), 184(86n), $187(150 \mathrm{n})$; and Nineteenth Route Army, 183(59n); Red Agrarian Army, 183(59n); relation to Nanyang Chinese, 12; Malay Communist Party, 72-74, 83, 170(34n, 35n), 182(40n), 184(100n); Indonesian Communist Party, 84, 170(34n); Philippines Communist Party, 93, 176(122n, $127 \mathrm{n}), 176(27 \mathrm{n})$

Communists, 15, 21-26, 31, 32, 72, 82-83, 84, 93-94, 97-98, 100, 104-105, 106, 109-110, $116,118-119,155,161,173(57 \mathrm{n}), 176$ $(121 n), 184(100 n), 188(174 n), 189(211 n)$; Chinese Communists, 3, 57, 74, 164, 190 (15n); General Labor Union, 12, 20, 170 (34n); infiltration into the National Salvation Movement, 20, 22; Penang riot, 27; South China Bureau (Hong Kong), Eighth Route Army, 74, 97, 98, 179(177n); relations with Tan Kah Kee, 74-81; Chinese Race Armed Self-Defense Society, 189(3n)

Congress, KMT. See Chinese Nationalist Party (KMT)

Conros Island, $181(35 n)$

Consular Act for the Guidance of Hua-ch'iao Schools and Auxiliary Schools, 11

Consular Act for the Guidance of Hua-ch'iao Shu Pao She and Other Educational Facilities Concerning Lectures to be Given on Sundays and Memorial Days, 11

Consular Regulations for the Legislation and Administration of Hua-ch'iao Education, 11

Contribution campaign, 119-128, 160; in Singapore and Malaya, 27-30, 119; in the Dutch East Indies, 34, 86-87, 119; in the Philippines, 43, 49, 50, 119, 128, 175 $(112 \mathrm{n})$; in Thailand, 57, 102, 123, 128, 187(166n); in French Indochina, 59, 60, 108,123 ; in Burma, 61; KMT officials solicit contributions, $120-121$; results of, 122-128. See also "Save China by Airplanes" campaign

Cotton Cloth Dealers' Association (Philippines), 46

Cua Chün-ti, 90, 91, 186(134n)

Dalley, Colonel, 83

Davao, 49; Chinese Resist-the-Enemy Committee in, 94

Decoux, Governor General, in French Indochina, 108

Dee Huanchay, 175(109n)

Dee Lien-tau, $187(151 \mathrm{n})$

Domei, 175(116n)

Dutch, envoy sent to China (1741), 1

Dutch East Indies, Government of, 34, 35-36, $39,40,41,84-85,86,128,174(97 \mathrm{n}), 184$ (108n); relations with Japan, $84-86,174$ $(97 n), 175(106 n)$
Economic conditions, 127, 136, 140, 146, 193 $(87 \mathrm{n})$; in Singapore-Malaya, $30,124,135$; in China, $192(67 \mathrm{n})$

Education, Ministry of. See Kuomintang (KMT), Government

Eighth Route Army. See Communists under South China Bureau

Emancipation News, 182(40n)

Emerson, Rupert, Professor, 12

Exchange Transaction Act, 1938, 130

Executive Yüan of KMT Government. See

Kuomintang (KMT), Government of

Fang, C. C., 91, 186(134n)

Federation of Malaya Chinese Relief Fund Raising Association, Office of, 28

Foochow, 130

Fookien Times (Manila), 8, 91, 170(24n)

Foreign Affairs, Ministry of, Japan. See Japan, Government of

Foreign Ministry, China. See Kuomintang (KMT), Government of

French Indochina, Government of, 60, 109, 193(98n, 99n, 100n)

Friends of China, 177(145n), 186(141n, 142n)

Friends of the Soviet, 93

Fukien, Province of, 76, 77, 79, 80, 89, 118, $138,183(59 \mathrm{n}), 185(126 \mathrm{n})$; ChangchowAmoy Railway in, 138

Fukien Overseas Chinese Construction Co., 139

Fukien Overseas Chinese Enterprise Co., 140

Fukienese, 63, 65, 66, 162; in Singapore, 19, $29, \quad 30,80,184(80 \mathrm{n})$; in Dutch East Indies, 38; in French Indochina, 107; rivalry with the Cantonese, 31, 32, 41

Fukienese Chinese, Association of, 23

Gan Bun-chu, 175(109n), 187(151n)

General Association for Vietnam and Southern District Chinese Salvation, 59-60, 179 (180n)

General Labor Union. See Communists

Germany, 73, 182(44n)

Go Chun-ming, 175(109n)

Go Kao-ju, 186(151n)

Go Puan-seng, 170(24n), 175(109n)

Gold Bonds. See Bond subscriptions

Greater Asian Co-Prosperity Sphere, 70

Greater East Asian Assembly, 71

Guerrilla Squad for the Eradication of Traitors, 21

Gunji Kiichi, Consul General, 18

Haikow, 131, 181(35n)

Hainan Island, 25, 54, 130, 150

Hainanese, 25, 29, 31, 56, 57, 59

Haiphong, 59, 60

Haiphong-Hanoi-Kunming Railroad, 109, 111, 113,115

Hakka, 19, 29, 41; Hakka Association, 19

Hanchow, 18

Hanoi, 59, 60, 101, 102, 107, 110, 130, 157 
Hanoi-Yunnan (Kunming) Road, 107

Hara Shigeharu, 46

Hidaka Shinrokurō, 171(6n)

Higashi Indo Nippō, 85, 174(84n)

Ho Pao-jen, 65

Ho Ying-Ch'in, General, 78, 116, 183(56n, $67 n)$

Hong Kong, 15, 19, 63, 74, 102, 158

Hong Kong and Shanghai Banking Corporation, 132

Hong Kong Overseas Chinese Co., 139

Hot Blood Youth Corps for Resist-the-Enemy and National Salvation and Eradication of Traitors, 97

Hsiao Chi-shan, 106, 120

Hsiao Fo-ch'eng, 58-59, 128

Hsieh Teh-ch'ao, 91, 186(134n)

Hsien Tai Jit Poh (Penang), 80

Hsin Kuo Min lit Poh (Singapore), 8

Hsing Tao lit Pao (Hong Kong), 68, 110

Hsü, Consul General, 43-44, 45, 48, 176 $(117 n), 177(132 n)$

Hsü Ching, 97

Hsü Kuan-chih, 121

Hsü Shih-ying, 116

Hua-ch'iao chi-k'an, 181(34n)

Hua-ch'iao Jih Pao (Bangkok), 8, 96-97

Hua-ch'iao Jih Pao (Cholon), 8

Hua-ch'iao Rescue-Squad-for-Bangkok Guerrilla Committee, 98

Hua Hsi Land Development Co., 139, 141

Hua Hsien Jih Pao (Bangkok), 8

Hua-K'ang (Hua-ch'iao Resist-the-Enemy Association for National Salvation), 54, 56, 59

Hua Sheng lit Pao, 97

Huang Chi-sheng, 138

Huang Chung-chi, 65

Huang Hai-shan, 187(151n)

Huang Hua Kang Revolt, 1911, 1-2, 29

Huang Liang, 182(41n)

Huang Neng-jung, 121

Huang T'ien-chüeh, 121

Huang Yi-t'ang, 65

Huichou Chinese Association, 114

Hundred Days of Reform, 1898, 159

Hung Yüan-yüan, 65-66

Hypothec Bank of Japan, 181(35n)

Ichikawa Kenjirō, 118, 188(188n), 190(15n)

Ide Kiwata, 181(29n)

I-ho-hsüan Club, 28, 173(59n)

Indians, 23, 61

Indonesian Communist Party. See Communist Party

Inflation, in China, $190(31 \mathrm{n})$

Internal Affairs, Ministry of. See Kuomintang (KMT), Government

International Military Tribunal, Far East, $184(104 n)$

Investments, $137-141,160,192(77 \mathrm{n}) ; \mathrm{KMT}$ government solicits investments, 137-138, $192(68 \mathrm{n})$

Ipoh, 17, 20, 27
Iron Blood Corps, 61

Iron Blood Youth Anti-Japanese Association, 97

Ishihara Mining Company, 21

Ishizawa, Consul General, 185(114n)

Isoya Gorō, General, 181(30n)

Issara (Bangkok), 8

Itagaki Yoichi, Professor, 185(109n)

Japan, 2, 3, 7, 32-33, 46, 51, 52, 53, 69-70, $72,84-85,94,103,177(146 \mathrm{n})$; intelligence activity in Thailand, 101, 105, 187 (153n); advance to French Indochina, 108$109,135,146,189(203 \mathrm{n})$; intelligence agent in Hanoi, 110; countermeasures to attract remittances, 131-132; boycott effectiveness, 141-158; intelligence activity in the Dutch East Indies, 185(109n); trade relations with Southeast Asia, 193(86n, $93 n, 96 n, 97 n, 98 n, 99 n, 100 n)$; pays reparation for "Blood Debt," 194(6n)

Japan, Government of: Army, Ministry of, $180(26 n, 27 n)$; Colonial Affairs, Ministry of, 180(26n); Foreign Affairs, Ministry of, $49,85,131,174(83 \mathrm{n}), \quad 180(26 \mathrm{n}), 185$ $(114 \mathrm{n}) ;$ Kikakuin (Planning Board), 180 (26n); Köain (China Development Board), $85,180(26 n), 181(35 n), 191(33 n)$; Navy, Ministry of, $139-140,180(26 \mathrm{n}, 27 \mathrm{n})$

Japanese, 26, 30, 36, 42, 48, 49, 51, 95, 160, $167,172(23 \mathrm{n})$; in Singapore-Malay: assaulted, 16, 22, 171(15n); in Dutch East Indies: harassed, 35; intelligence activity, $185(109 \mathrm{n})$; in the Philippines, 49, 88, 153, $175(115 \mathrm{n}), 193(93 \mathrm{n})$; in Thailand, 53, 55, 58; invasion of Malaya, 82-84; invasion of the Philippines, 95-96

Japanese Chamber of Commerce (Manila) See Japanese under in the Philippines

Japanese consulate, 27, 39-40. See also Gunji Kiichi; Kihara Jitarō; Yoshida Tan'ichirō Japanese military, 109-110, 185(126n)

Jen Yeh-yuan, 134

Jews, 55, 106, 178(170n)

Johore Bahru, 26

Kaga Misao, 174(83n)

K'aiyuang Crockery Co., 139

Kak Min lit Poh (Rangoon), 8, 61

Kann, Edward, 132-133, 134

Kao Ling-pai, Consul General, 16, 17, 23, 29 , $63,66,79,80,82,98,163,181(34 \mathrm{n}), 183$ $(76 n), 184(80 n)$

Kao Ling-pai, Mme., 29, 30, 183(76n)

Kao Shih-heng, 121

Kao Tsung-wu, 171(6n)

Kawamura Saburō, General, 184(104n)

Kedah, 25, 28

Kelantan, 28

Kempeitai, 19, 39, 84, 88, 96, 170(35n), 184 $(104 n), 185(121 n), 187(151 n)$

Keng Po (Surabaya)

Khao Siam (Bangkok), 8

Khu Khan (Thailand), 98 
Kihara Jitarō, Consul, 88, 93, 176(127n), $178(148 \mathrm{n})$

Kikakuin (Planning Board). See Japan, Government of

KMT-Communist United Front, 12, 20, 24, $32,75,76,93-94,96,118,162-163$

Ko Tsu-k'uang, Consul General, 38, 66, 86$87,174(99$ n)

Kóain (China Development Board). See Japan, Government of

Kong Li Po (Manila), 8, 90

Konoye Fumimaro, 68; Konoye Proclamation of Three Principles, $68-69,180(17 \mathrm{n})$

Koshiba, Naosada, Commander, 131-132

Kow Say Huan, 65, 73, 75, 76, 81, 172(30n)

$\mathrm{Ku}$ Chün-ying, $173(57 \mathrm{n})$

Kuala Lumpur, 26, 27, 117, 172(23n)

K'uang Huan-shun, 138

Kueiyang, 116, 138

Kung Hsiang-hsi, 44, 45, 63, 64, 67, 68, 77, $116,120,128,136$

Kunming, 102, 110, 114, 116, 130, 138

Kuo T'ien, 97

Kuomintang (KMT), Government of, 1, 2, 3, $17-18,31,34,37,55,56,57,58,66,68$, $71,74-83,95,102,104-105,106-107,113$, $115,119,127,128,130-136,137,159-$ $162,164-166,169(16 \mathrm{n}), 175(113 \mathrm{n}), 183$ $(67 \mathrm{n}), 184(81 \mathrm{n})$; Consulates, $1,11,87$, 96, 107, 170(30n); Overseas Chinese Affairs, Office of, 2; Foreign Ministry, 3, 10, 11; Executive Yüan, 6, 10; Overseas Chinese Affairs Commission, 8, 10, 11, 53, $106,113,124,125,126,181(35 \mathrm{n})$; Internal Affairs Ministry, 8; Central News Agency, 9, 52, 61; Education Ministry, 10-11; factional strife in the Philippines, 89-94; Commercial Representative, Office of (Bangkok), 96; Political Council (Ts'an-cheng-yüan), 96, 174(95n); Central Executive Committee, 136

Kwang Wah lip Poh (Penang), 8

Kwangsi Development Co., 140

Kwangsi Sugar Co., 140

Kwangtung Bank, 100

Kwee Bok Ai, 38, 174(90n)

Labor-Comrade National Salvation Association, 98

Laborers' Resist-the-Enemy and National Salvation Corps, 98

Labouring Classes Anti-Enemy-Backing-up Society, 21. See also Communists under General Labor Union

Lak Muang (Bangkok), 8

Land Development Co., 140

Landon, Kenneth P., Professor, 101, 187 $(162 \mathrm{n}), 188(168 \mathrm{n})$

Lan-yi she, 11-12

Lava, Jose, $186(142 n)$

League for the Defense of Democracy, 45 , $93,176(121 \mathrm{n}), 177(145 \mathrm{n}), 186(141 \mathrm{n})$
League of Kwangtung Chinese for Relief, 110

Lee Chim Tian, 65, 140

Lee Kong Chian, 28, 64

Leyte, 49

Li-chih she, 56, 173(58n)

Li Hao-chu, 176(120n)

Li Hsiao-wu, 65

Li Shui-li, $180(27 n)$

Li Ssu-yüan, 121

Li T'ien-ho, $180(27 n)$

Li Tsung-jen, $180(27 n)$

Liang Jui-nan, 65

Liao Ch'eng-chih, 97, 179(177n)

Liaotung, Peninsula of, 2

Lie Kiem Tjoan, 38, 174(90n)

Lie Ngo An, 38

Lim Boon Keng, 66

Lim Han Hoe, 66

Lim Shu-an, 47, 175(109n), 176(129n), 187 (151n)

Lin Chiang-shih, 184(100n)

Lin Lung-hua, $182(41 \mathrm{n})$

Lin Shen, 77, 80, 116, 117, 180(18n)

Lin Tso-mei, 91, 92, 121, 186(134n)

Liu Chin-shen, 120

Liu Pi-ch'uan, 97

Liu Yü-shui, 65

Lo Jung-Kuang, 98

Loi Tek, 72, 83, 170(35n), 184(100n), 185 (104n)

Loshan Declaration, 67

Lü Chia-wei, 121

Lum Mun Tin, 65, 72

Lung Yun, 116, 140

Ma Ch'ao-chüh, 191(55n)

Ma Hua lih Pao (Kuala Lumpur), 8

Ma T'ing-huai, 121

Macao, 130

Makassar (Celebes), 33, 39

Malacca, 17, 25, 28

Malang (Java), 84

Malay Anti-Enemy and National Salvation Corps for the Eradication of Traitors, 21, $23,25,27$

Malay Communist Party (MCP). See Communist Party

Malay Peninsula, 12

Malaya All Chinese Classes Anti-EnemyBacking-up Society, 21, 27

Malayan People's Anti-Japanese Army, 83, 184(99n)

Malayan Tribune, 17

Manado (Celebes), 33, 39

Manchu government (1636-1911), 1, 159; policy toward the Overseas Chinese, 1; anti-Manchu movement, in Malaya, 1-2

Manchurian Incident, 1931，3，29，41，52, $58,59,178(149 n)$

Manila, 44, 45, 48, 49, 50, 95, 130, 175 (115n)

Manila Chinese Chamber of Commerce, 42, $43,45,48,49,92,94,96,163,175(109 \mathrm{n})$, $176(124 \mathrm{n})$ 
Manila Guardian, 176(121n)

Mantetsu (Manshū Tetsudō Kabushiki Kaisha, South Manchuria Railway Co.), 141, $178(170 \mathrm{n}), 180(26 \mathrm{n})$

Mao Tse-tung, 75, 76, 182(54n), 187(150n)

Marco Polo Bridge Incident, 12-13, 15, 29, 160 ; reaction to: in Malaya, 16; in the Dutch East Indies, 15, 33; in the Philippines, 15,42

Mass Movement Guidance, Department of. See Chinese Nationalist Party (KMT)

Matsumoto Sökichi, 181(29n)

Matsuoka Yōsuke, 161

May Fourth Movement, 1918, 2, 28

McLane, Charles, Professor, 93, 186(142n)

Medan (Sumatra), 33, 39, 87

Mien-tzu (face), 41, 174(87n)

Military Administration in Malay, Japan, $167-$ $168,181(30 n), 184(104 n), 185(121 n)$

Min Kuo Jih Pao (Bangkok), 8

Ming dynasty (1368-1639), 1

Mitsubishi, 105

Mitsui, 53, 54, 105, 180(26n), 188(174n); research office of, 101

Miyoshi Shunkichirō, 174(87n)

Mo Ying-kuan, 120

Morrison, Ian, 82, 84

Muar, 17

Murai, Minister, 52, 53

Nakamura Aketo, General, 188(188n)

Nami Shūdan, 188(178n)

Nanch'ang, 17

Nanking, 15, 17; fall of, $21,37,53,152$

Nanking, Government of (Wang Ching-wei government), 101, 117, 130, 161, 177 $(160 n), 181(34 n)$; policy toward Nanyang Chinese, 70-72, 85, 89; Nanyang Chinese reaction to, 71-72; established Overseas Chinese Affairs Office, 131

Nanshi Chōsakai (South China Research Institute), $180(26 \mathrm{n})$

Nanyang Chinese (Nanyang Hua-ch'iao, or South Seas Chinese), 1; and Chinese Revolution, 1911, 2; and Twenty-One Demands, 1915, 2; and May Fourth Movement, 1918, 2; and Anti-Japanese boycott, 1924, 2; and Tsinan Incident, 1928, 3, 24; and Manchurian Incident, 1931, 3

Nanyang Chinese Relief General Association (NCRGA), 28, 57, 60, 79-80, 103, 104, $107,108,113,122,124,125,136,161$ $162,179(3 n, 8 n), 181(34 n)$; organized, 65; and Wang Ching-wei, 67-69; organized Return Home Service Drive, 113115; organized Comfort Missions, 115$119,190(20 n)$

Nanyang Fukienese Chinese General Assembly, 80

Nanyang Hua-ch'iao Communities: Clannishness, 20, 161-162. See also Baba, Cantonese, Fukienese, Hainanese, Hakka, Sinkheh, Teochiu

Nanyang Hua-ch'iao Youth League, 98
Nanyang Siang Poh (Singapore), 8, 68, 71, $128,170(24 n), 190(20 n)$

Nan-yang Brothers Tobacco Co., 139

Nan-yang Chinese Land and Forestry Co., 140

Nanyō Kyōkai (South Seas Research Institute), 18, 171(15n), 180(26n)

National Defense Bonds. See Bond subscriptions

National Salvation Movement: in TwentyOne Demands, 2; in May Fourth Movement, 2; in Tsinan Incident, 3; in Manchurian Incident, 3. See also Boycott

National Spiritual Mobilization Movement, 68-69

National War Salvation Bonds. See Bond subscriptions

Nationalism, 159-160, 163-165, 167; Chinese nationalism, 1, 3, 80, 159; Overseas Chinese nationalism, 38, 41; Thai nationalism, $55,99,165$

Navy, Ministry of, Japan. See Japan, Government of

Negri Sembilan, 28

New China Drama Team, 121

New Fourth Army, 75, 183(69n); massacre of, $78,81,94$

New Guinea, 33, 39

Newspapers (Chinese and Japanese). See individual listings

Nguyen Ai Quoc (Ho Chi Minh), 109-110

Northwest Overseas Chinese Co., 139

Ong Chuan-sien, 65, 66, 89, 90, 92, 175 $(109 n), 184(80 n), 186(130 n)$

Ong Seh-hsiun (Ong Keit), 187(150n)

Onraet, Rene H., 170(32n)

Organization, Department of. See Chinese Nationalist Party (KMT)

Organization Act for the Overseas General Headquarters Executive Committee, 1934, 6

Organization Law, 1931, 10

Organization Laws Concerning People's Associations, 1933,9

Ōtani Chōzō, 55

Overseas Chinese Affairs Commission. See Kuomintang (KMT), Government of

Overseas Chinese Affairs, Office of. See Kuomintang (KMT), Government of

Overseas Chinese Bank, 35, 100, 140

Overseas Chinese Bank of Development, 139

Overseas Chinese Construction Co., 140

Overseas Chinese Enterprise Co., 139, 140

Overseas Chinese Investment Information Office, 137

Overseas Chinese Land Development Co. 139,141

Overseas Chinese Western Development Co., 139

Overseas Compatriot Investment Encouragement Act, 1939, 137, 192(71n)

Overseas Party Affairs, Department of. See Chinese Nationalist Party (KMT) 
Pacific War, 82, 90, 105, 106, 110, 119, 141, 166

Pahang, 28

Pai Ch'ung-hsi, General, 78

Palembang (Sumatra), 33, 39, 87, 125

P'an Kung-chan, 120,176(120n)

P'an Kuo-ch'ü, 116

Pang (group), 28, 29

Penang, 17, 20, 25, 27, 28, 130, 169(7n), $180(23 n)$; riot in, 26

Penang Git Poh, 71

Perak, 17, 28

Perlis, 28

Phao, 174(83n)

Pharmaceutical Co., 139, 190(20n)

Phibun Songkhram, Luang, 99, 103, 188 $(172 n, 180 n)$

Philippines, Government of, 128, 176(124n), $186(141 \mathrm{n})$; reaction to boycott, 47,51 , $91,94,186(131 \mathrm{n})$

Philippines Chinese Women's Association for the Comfort of Self-Defending Soldiers, 50

Philippine Resist-the-Enemy Committee (PREC), 44, 45, 46, 47, 48, 49, 88-89, 95, 175(111n), 177(130n, 131n), 189(211n); organized, 43, 175(110n)

Plans for Mass Movement to be Guided by Party Chapters and Wards, 1933, 7

Political Parties. See Communist Party; Chinese Nationalist Party; Sakdalista

Pontianak (Borneo), 15, 33, 39

Port Swettenham (Malaya), 17

Pradjist Manudbam, Luang, Foreign Minister, 52

"Principles Governing People's Organizations During Emergency Time," June, 1940, 75

Principles of Hua-ch'iao Education, 1932, 10

Promotion of Bond Subscriptions, Burma Branch of, 110

Promotion of Chinese Culture, Association for, 107

Propaganda, Department of. See Chinese Nationalist Party (KMT)

Propaganda Operation Plans to be Implemented by the Chinese General Headquarters and Branch Offices, 1931, 8

Puasa, 36

Pu-p'ien-pu-tang, 81, 164

Quezon, Manuel, President, 47, 51, 93, 171 $(140 n), 177(140 n, 147 n), 178(148 n)$

Rama IV, King of Thailand, alias Asavabahu, 178(170n)

Rangoon, 61, 130

Red Blood Brigade, 18, 31

Red Cross, 35, 110

Registration Act for Overseas Chinese Newspapers and Magazines, 1934, 8

Regulations Governing Encouragement for Overseas Chinese Investment in Domestic Economic Undertakings During Emergency Period, 1938, 137
Regulations Governing the Purge and Registration of Enemy Goods, 1939, 89, 152

Relief Association of Guilds, 110

Remer, F. C., Professor, 130, 193(83n)

Remittances, 129-136, 160-161, 180-181(28n, $29 n, 35 n), 191(38 n, 51 n), 192(58 n)$; remittances before 1937, 120; KMT effort to attract remittances, 130-131; Japanese policy to attract remittances, 131-132; remittances and China's balance of payments, $130,132-135,191(48 \mathrm{n}), 192(57 \mathrm{n})$

Return-Home Service Drive, 113-115, 160, $189(3 \mathrm{n}), 190(10 \mathrm{n})$; failure of, 115; Tan Kah Kee sends an investigation team, 114; Penang Chinese Relief Fund-Raising Association withdraws, 114

Returned Overseas Chinese Association in Kwangtung for the Promotion of Industry, 140

Reuters, 67

Revised Guiding Principles for Mass Movement, 1933, 7

Rice Merchants Association, 98

Rice Mill Association, 98

Sai Kuo-ch'üan, 90, 91-92, 175(109n), 186 (135n)

Saigon, 59, 60, 107, 109-110

Sakdalista, 45, 176(122n)

San-Min-Chu-I, 2, 9, 10, 11, 45, 56, 117, 159, $170(24 n), 174(99 n)$

San-Min-Chu-I Youth Corps, 74-75, 81, 90, $91,100,182(51 \mathrm{n})$

San-min she, 56, 100

Santos, Pedro Abad, 45, 176(122n)

sari sari, 177(147n), 178(148n)

Satō Eisaku, Premier of Japan, 194(6n)

Satō Junzō, 189(203n)

"Save China by Airplanes" Campaign, 50

Sayre, Francis B., High Commissioner, 95, $186(131 n)$

Secret societies. See individual listings

Semana Santa (Holy Week), 45, 46, 152

Semarang (Java), 38, 39, 41

Seremban (Malaya), 26

Sha Kuo-chen, 121

Shanghai, 89, 133, 137, 138; capital flight to, 134,135

Shensi Development Co., 140

Siam, 12

Siam Chronicle, 54, 101

Sin Chew Jit Poh (Singapore), 8, 19, 71, 80, $170(24 n), 179(16 n), 181(34 n)$

Sin Chung Git Poh, 71

Sin Po (Batavia), 8, 40, 66, 170(24n)

Singapore, 11, 15, 17, 20, 22, 25, 26, 28, 33, $35,63,78,82,117,125,130,180(24 \mathrm{n})$; police, 23, 27; battle of, 83 ; massacre of Chinese in, 184(104n), 194(6n). See also Sook Ching

Singapore All Chinese Classes Anti-EnemyBacking-up Society, 21

Singapore Chamber of Commerce, 16, 17, 23, 24,31 
Singapore Chinese General Association for the Relief of Refugees in China, 17-18, 19, 28,30

Singapore Chinese League, 12

Singapore Women's Classes Anti-EnemyBacking-up Society, 21

Sinkheh (China-born Chinese), 33, 38, 41, $110,124,128-129,162$

Skinner, G. William, Professor, 51, 99, 155

Song Ong Siang, 66

Sook Ching (purification by elimination) 166, 184-185(104n), 194(6n). See also Singapore under massacre of Chinese in

South China Bureau, Eighth Route Army. See Communists

Soviet-Finnish War, 1939, 189(211n)

Soviet-German non-aggression pact, 73

Ssu-fan, 24-25, 31

Su Tang-jung, $173(57 \mathrm{n})$

Sugita Ichiji, Colonel, 83

Sumatra, $12,33,39,84,88$

Sumatra Min Po, 40

Sun Fo, 117, 120, 126; visited Singapore, 24

Sun Weng-t'ao, 121

Sun Yat-sen, 1, 2, 3, 29, 169(7n, 8n)

Sung Che-yuan, General, 42

Sung Ch'i Forestation Co., 140

Sung Tzu-wen, 180(27n)

Surabaya, 35, 39, 125, 130

Swatow, 25, 54, 99, 100,130, 131, 180-181 $(28 \mathrm{n}), 181(35 \mathrm{n}), 187(158 \mathrm{n})$

Sy Kao-yu, $187(151 \mathrm{n})$

Sy Yat-sien, 90, 91, 175(109n), 186(134n)

Ta-Ch'ing Lü-li, 1, 169(6n)

Ta Kong Siang Po (Surabaya), 40

Tai King-hwa (Te Kin Hua), 89

Tai Kui-sheng (Tai K'uei-sheng), 89, 120, 121

Tai $\mathrm{Li}, 11,170(32 \mathrm{n})$

Tai 'T'ien-ch'ou, 121

Taierchwang, 49

Taiping, 26

Taiwan, Government General, 131, 180(26n) $181(35 n)$

Tan Cheng Lock, 171(36n)

Tan Chin Hean, 65

Tan Ean Kiam, 65

Tan Kah Kee (Ch'en Chia-Keng), 17, 19, 24, $26-27,28,30,32,63,64-65,66,82,83$, $84,123-124,126,128,136,138,140,162$, $163,164,170(24 n), 172(30 n), 173(59 n)$, $179(8 \mathrm{n}), 180(27 \mathrm{n}), 183(71 \mathrm{n}, 75 \mathrm{n}, 76 \mathrm{n})$, 184(81n, 86n, 103n), 190(15n), 191(33n); controversy with Wang Ching-wei, 67-69, $180(18 \mathrm{n})$; and Communists, 74-81, 182 $(53 n, 54 n), 183(56 n, 59 n, 71 n)$; on factfinding tour, 75-78; controversy with Ch'en Yi, 77; controversy with Kao Lingpai, 79-80; controversy with Wu 'T'iehch'eng, 79, 80; and Return-Home Service Drive, 114-115; and Comfort Missions, 115-119

Tan Mu-ting, $187(151 \mathrm{n})$
Tan Samto, 65, 175(109n), 177(139n)

Tan Unliong, 90, 91-92, 175(109n), 186 (135n)

Tandjoeongbalai (Sumatra), 33, 87

Tang-hua chiao-yü, 74, 159

Ten Principles for the Protection of the Chinese in Emergency, 95

Teo Eng-Hock (Chang Yung-fu), 120

Teochius, 29, 56, 59, 190(15n)

Thai Chinese Relief Fund-Raising Association (TCRFRA), 56, 59, 96-97, 99, 101, 104, 105

Thai-ification, 99, 102-103

Thai-Indochinese territorial dispute, 103-104, $108,188(180 \mathrm{n})$

Thailand, Government of, 51, 52-53, 99-100, $102,106,128,178(149 \mathrm{n}), 178(172 \mathrm{n}), 187$ 152n), 193(96n, 97n); suppressed Chinese newspapers, 52, 100; reaction to terrorism, $53-54,55-56,99,179(177 \mathrm{n}), 187(161 \mathrm{n}$, $162 \mathrm{n})$; relations with KMT Government, $102-103,188(172 \mathrm{n}, 184 \mathrm{n})$

Thailand Hua-ch'iao League for Anti-Japanese Executive Committee, 98

Thailand Hua-ch'iao League for the AntiJapanese National Salvation Movement, 97

Thailand Hua-ch'iao Women's Anti-Japanese National Salvation Association, 98

Thailand Youth League for Anti-Japanese National Salvation, 97

Thais: Adverse reaction to terrorism, 54-55, 101, 102

Thien Sung Jip Po (Batavia), 8, 40, 174(99n)

Thio Thiam Tjong, 39

Thomas, Shenton, Sir, 82

Three People's Principles. See San-Min-Chu-I

Tiao Tso-ch'ien, 19, 120, 121

Tiger Association, 61

Ting Pe'i-lun, 120, 179(175n)

Ting Pe'i-tz'u, 120, 179(175n)

Tjong Ch'ing-te, 88

Tjong See-gan, 34, 39, 40, 41, 42, 63, 64-65, $80,86,140,174(95 \mathrm{n})$

Tōa Kenkyūjo (East Asia Research Institute), $180(26 n), 191(48 n)$

Trade. See Japan under trade relations with Southeast Asia

Training, Department of. See Chinese Nationalist Party (KMT)

Trengganu, 21, 28

Ts'ai chih-fang, 97

Ts'ai T'ing-kai, General, 42, 175(108n), $182(54 \mathrm{n})$

Ts'an-cheng-yüan (Political Council). See Kuomintang (KMT), Government of

Tseng Chung-Ming, 107

Tseng T'ing-chüan (Justo Cabo Chan), 43, $45,46,47,48,90,163,175(109 n), 175$ $176(116 n), 176(122 n, 129 n)$

Tseng T'ung-ch'un, 121

Tsinan Incident, 1928, 3, 24, 45, 59

Tsurumi Yūsuke, 161

Tsutsui Chihiro, 185(121n)

T'uan, C. C., 11-12, 90 
T'ung-hsi she, 56

T'ung Meng Hui, 169(7n)

T'ung-teh shu-pao she, 173(58n)

Twenty-one Demands, 1915, 2

Tzuchung Sugar Co., 139, 141

Ubon (Thailand), 98

Uchiyama Kiyoshi, Consul General, 177 (140n)

Union Times, 71

United States, 46, 94, 145, 153, 183(67n); competition with Japanese goods in the Philippines, 193(93n)

Uy Mien-ta, 187(151n)

Vanguard News, 182(40n)

Vichy, Government of, 108

Voluntary Association for National Salvation, 107

Wang Cheng-t'ing, 90, 121

Wang Ching-wei, 66, 67, 71, 89, 107, 109, $148,150,152,157,180(23 n, 24 n), 181$ $(29 n), 183(76 n), 188(171 n)$; controversy with Tan Kah Kee, 67-69(180n); his government established, 70. See also Nanking, Government of

Wang Kung-ch'üan, 121

Wang Ming, 76

Wang Shih-chieh, 116

Wang Tso-Sheng, 97

Wang Yen-chi, 27, 173(57n)

Wee Swee Teow, 66

Wen Yü-ho, 121

Wijit Wathakan, Luang, 55, 178(170n)

Willmott, Donald, Professor, 41

Wu Pi-yen, 100

Wu Tieh-ch'eng, General, 74, 78, 79, 80, 82, $86,87,91,110,121,125,128,136,138$,
$163,179(175 \mathrm{n}), 183(71 \mathrm{n}), 186(132 \mathrm{n}), 187$

$(161 n), 188(184 n), 191(36 n)$

Wuhan Chorus Group, 121

Wusung, 17

Yang Kuang-sheng (Kuangson Young), Consul General, 48, 49, 50, 95, 177(132n), $189(3 n)$

Yang Kuo-ch'ün, 172(27n)

Yang sheng Schoolmate Society, 173(58n)

Yang Sung, 97

Yang-t'ou kou-ju, 183(75n)

Yao Pai-lung, 121

Yeh Kung-ch'ao, 82

Yeh 'T'ing, General, 94

Yeh-yü Story and Drama Society, 173(58n)

Yenan, 75, 76, 81

Yi Kuang-yen, 97, 101-102, 188(171n)

Yin Feng-tsao, Consul, 189(203n)

Yokohama Species Bank, 181(35n)

Yoshida Tan'ichirō, Consul General, 91, 186 $(13 \ln , 141 \mathrm{n})$

Yoshizumi Tamegorō, 85, 86, 185(112n)

Young, Arthur, 126

Youth Blood Soul Corps, 189(211n)

Youth Le-hsin she, 27, 173(58n)

Yu ching-chin, 175(109n)

Yü Han-mou, 120, 179(175n)

Yü Hung-chün, 119-120

Yü I-t'ung, $170(24 n), 175(109 n), 187(151 n)$

Yu Khe Thai, 80, 175(109n, 111n), 177 $(139 n), 186(131 n), 187(151 n)$

Yu Shan-tung, 97-98

Yüan Shih-kai, 2

Yïeh shu pao she, 169(7n)

Yunnan, 102, 110, 114

Yunnan Overseas Chinese Development Co., 140

Yushitsu Jitensha, 49 